SZEGEDI TUDOMÁNYEGYETEM

GAZDASÁGTUDOMÁNYI KAR

KÖZGAZDASÁGTANI DOKTORI ISKOLA

\title{
AZ IFJÚSÁGI MUNKANÉLKÜLISÉG KIHÍVÁSAI AZ EURÓPAI UNIÓBAN
}

Doktori értekezés

\section{Témavezető:}

DR. UDVARI BEÁTA

adjunktus

Szegedi Tudományegyetem

Gazdaságtudományi Kar

\section{Készítette:}

URBÁNNÉ MEZŐ JÚLIA VERONIKA

Szegedi Tudományegyetem

Gazdaságtudományi Kar

Közgazdaságtani Doktori Iskola 


\section{KöSZÖNETNYILVÁNÍTÁS}

E doktori értekezés megírása során és az addig elvezető úton is nagyon sok segítséget kaptam. Ezúton szeretném megköszönni témavezetőmnek, Dr. Udvari Beátának, hogy az elmúlt évek alatt - a 2011-es Tudományos Diákköri Konferenciára való felkészüléssel kezdődően - mindig ösztönzött a tudományos munkára, és mind szakmailag, mind lelkileg támogatott benne.

Köszönettel tartozom továbbá Dr. Kiss Gábor Dávidnak az empirikus elemzéshez nyújtott segítségéért, Dr. Mozsár Ferencnek, aki elsőként adott lehetőséget arra, hogy a katedrára álljak, Prof. Dr. Farkas Beátának, aki felhívta a figyelmemet az ifjúsági munkanélküliség kérdésére, Prof. Dr. Voszka Évának a Doktori Iskola mühelyében nyújtott segítségéért, valamint az értekezés opponenseinek, Dr. Artner Annamáriának és Dr. Kotosz Balázsnak.

Hálás vagyok a Szüleimnek, akik mindig biztattak, irányt mutattak és lehetővé tették, hogy tanulhassak. Végül köszönetet mondok Férjemnek és Gyermekeimnek, amiért ebben a hosszú időszakban mindvégig mellettem álltak és támogattak. 


\section{TARTALOMJEGYZÉK}

Tartalomjegyzék

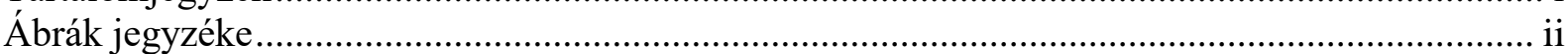

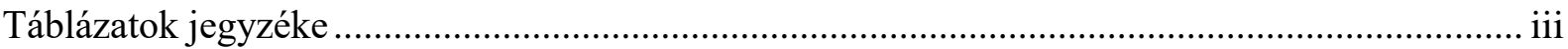

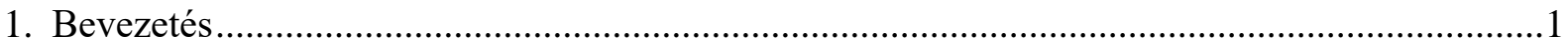

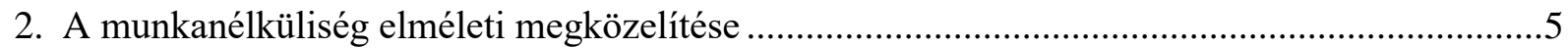

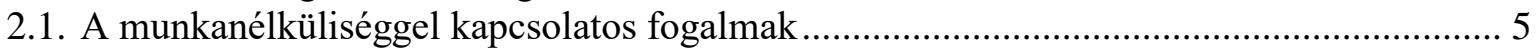

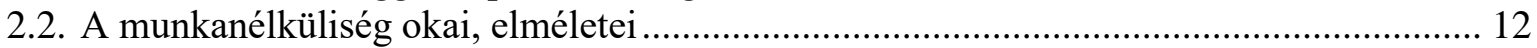

2.3. A gazdasági növekedés és a munkanélküliség kapcsolata ............................................... 19

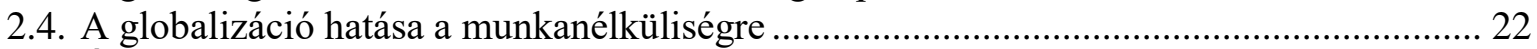

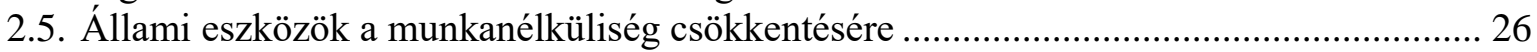

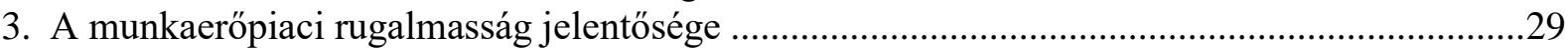

3.1. A munkapiaci rugalmasság elméleti megközelítése …........................................................29

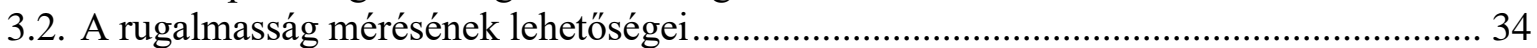

3.3. A rugalmasság hatásai a munkaerőpiaci szereplök csoportjaira ..................................... 36

3.4. A munkaerőpiaci rugalmasság szerepe a munkanélküliség alakulásában ........................ 40

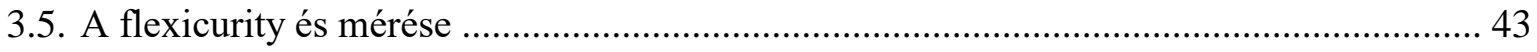

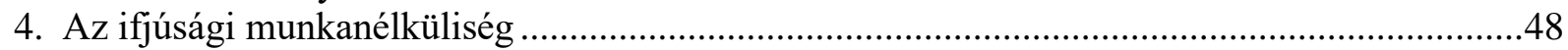

4.1. A munkanélküliség és az ifjúsági munkanélküliség alakulása az Európai Unióban.......... 49

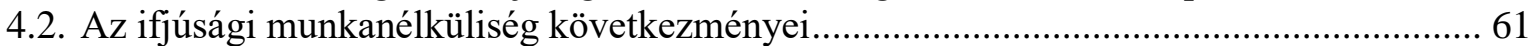

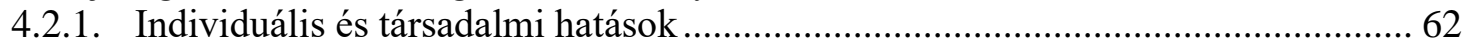

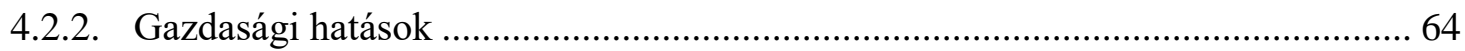

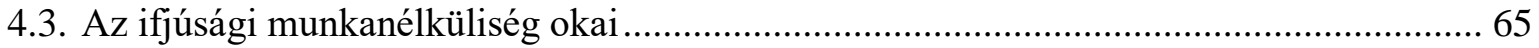

4.4. Korábbi empirikus vizsgálatok az ifjúsági munkanélküliség okairól ................................ 72

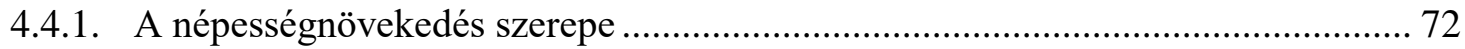

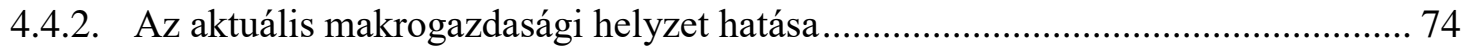

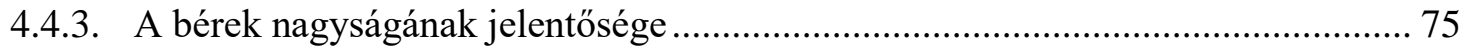

4.5. A munkaerópiaci rugalmasság hatásai a fiatalok munkaerőpiaci helyzetére ..................... 76

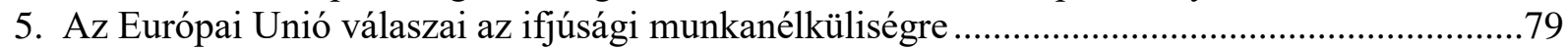

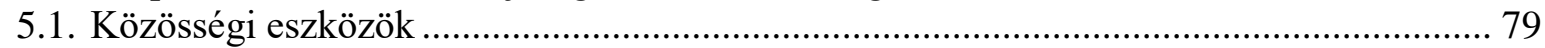

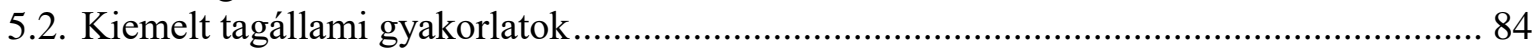

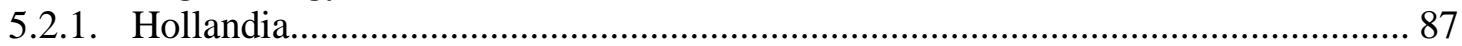

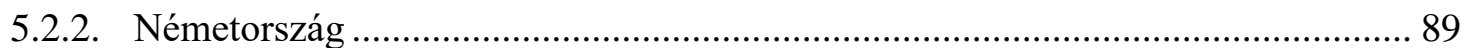

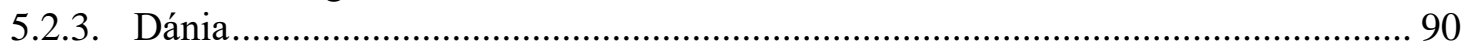

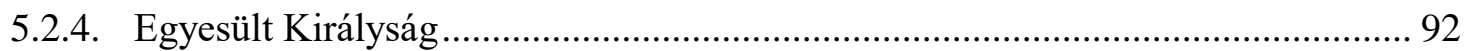

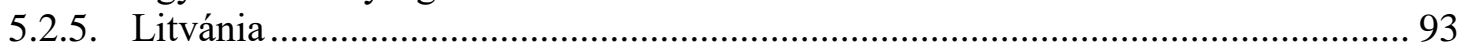

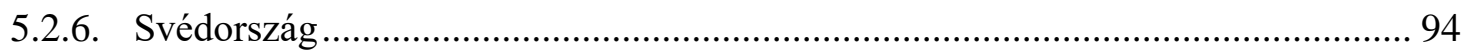

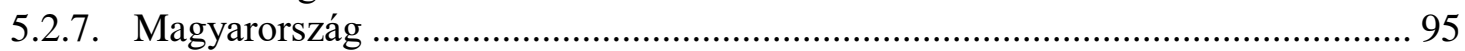

5.3. A közös jellemzök, jó gyakorlatok összefoglalása ......................................................... 97

6. A munkaerőpiaci rugalmasság fiatalok munkaerőpiaci helyzetére gyakorolt hatásának empirikus

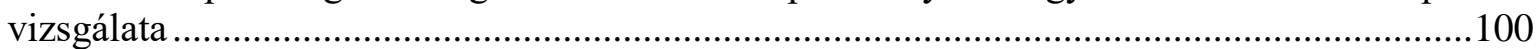

6.1. A vizsgált országok köre és a használt indikátorok ...................................................... 101

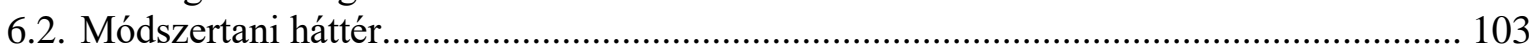

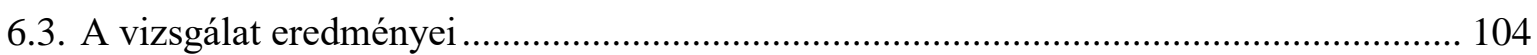

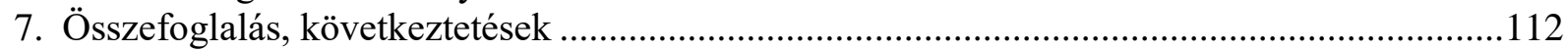

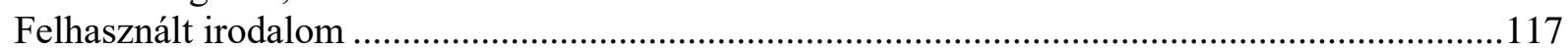

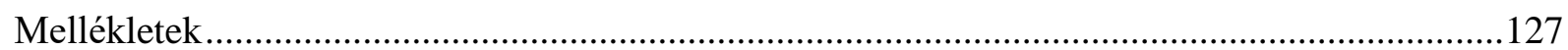

1. A teljes időszakra (2000-2015) elvégzett panel regressziók eredményei (Gretl)................ 127

2. Az első időszakra (2000-2007) elvégzett panel regressziók eredményei (Gretl) ................. 140

3. A második időszakra (2008-2015) elvégzett panel regressziók eredményei (Gretl)............ 149 


\section{ÁBRÁK JEGYZÉKE}

2.1. ábra Egy ország lakosságának csoportjai a munkához füződő kapcsolatuk szerint. 6

3.1. ábra A munkaerőpiaci rugalmasság jellemzői ................................................................... 34

4.1. ábra Fiatalok az Európai Unió munkapiacán (2016-os adatok; ezer fö).............................. 48

4.2. ábra A munkanélküliségi ráta alakulása az EU 28 országában és az USA-ban. (1963-2015; \%)

4.3. ábra Az aktivitási ráta alakulása az EU 28 országában és az USA-ban (1963-2015; \%)

4.4. ábra Munkanélküliségi ráta az Európai Unió 28 országában és az Egyesült Államokban (2007.01-2017.04.; szezonálisan kiigazított adatok; \%)

4.5. ábra A munkanélküliség tartósság szerinti megoszlása az EU 28 országában és az USA-ban (2007 és 2013; \%) .

4.6. ábra Munkanélküliek száma az EU 28 országában (2007.I.né.-2017.I.né.; szezonálisan kiigazított adatok; 1000 fö)

4.7. ábra A férfiak munkanélkülieken belüli aránya az Európai Unió 28 országában (2006-2016)

4.8. ábra A relatív ifjúsági munkanélküliség (RIM) alakulása az EU-28-ban (2001-2016) ........ 59

4.9. ábra Munkanélküliségi ráták az EU 28 országában és az USA-ban 2013-ban (\%) .............. 60

4.10. ábra Az ifjúsági munkanélküliség egyéni és társadalmi következményei ........................... 61

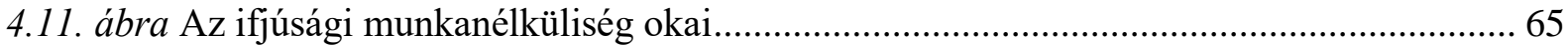

5.1. ábra Ifjúsági foglalkoztatottsági ráta a kiemelt tagállamokban (15-24 évesek; .....................

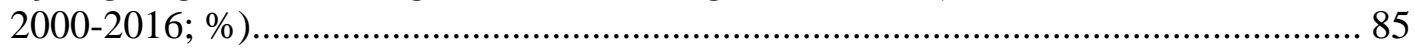

5.2. ábra Ifjúsági munkanélküliségi arány a kiemelt tagállamokban (15-24 évesek; ...................

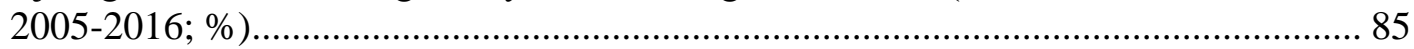

5.3. ábra Ifjúsági munkanélküliségi ráta a kiemelt tagállamokban (15-24 évesek; ......................

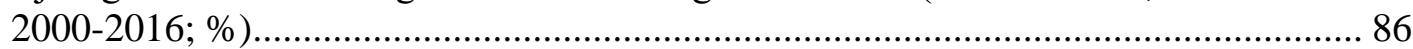

5.4. ábra NEET ráta a kiemelt tagállamokban (15-24 évesek; 2004-2016; \%) .......................... 86

5.5. ábra Az aktív munkaerőpiaci politikai eszközökre fordított kiadások a GDP ........................ arányában a kiemelt tagállamokban $(2005-2015 ; \%)$..................................................... 91 


\section{TÁBLÁZATOK JEGYZÉKE}

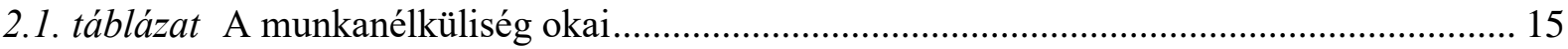

2.2. táblázat Közgazdasági elméletek a munkanélküliségröl ..................................................... 16

2.3. táblázat A munkanélküliség csökkenését segítő tényezök ….............................................. 27

3.1. táblázat A munkaerőpiaci rugalmassághoz kapcsolódó mutatók ........................................ 35

3.2. táblázat A munkaerőpiaci rugalmasság hatása a munkaerőpiac szereplőire ......................... 38

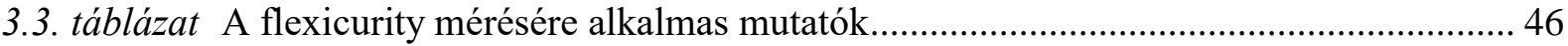

4.1. táblázat Az ifjúsági munkanélküliséget leíró, leggyakoribb mutatószámok ........................ 49

4.2. táblázat A legalább középfokú és a felsőfokú végzettségủek aránya az EU-ban és ................

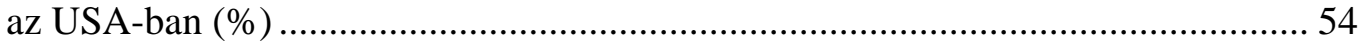

4.3. táblázat A munkanélküliségi arány változása az EU 28 országában (1000 fö) .................... 56

4.4. táblázat A munkanélküliség időtartama az EU-ban és az USA-ban................................... 57

4.5. táblázat Az ifjúsági munkanélküliség okai és a munkaerőpiac rugalmassága ..................... 71

4.6. táblázat Empirikus vizsgálatok az ifjúsági munkanélküliség okairól ................................. 72

4.7. táblázat A munkaerőpiaci rugalmasság és az ifjúsági munkanélküliség .............................. 77

5.1. táblázat Az EU főbb közös ifjúsági foglalkoztatási eszközeinek jellemzői ........................ 83

5.2. táblázat A részmunkaidős foglalkoztatottak aránya az EU egyes országaiban $(2015 ; \%)$.... 88

5.3. táblázat Jelentősebb munkapiaci politikai lépések a kiemelt tagállamokban ....................... 98

5.4. táblázat A részmunkaidős és határozott idejü szerződéssel dolgozó fiatalok ........................... (15-24 évesek) aránya az EU egyes országaiban 2015-ben (\%) ............................ 99

6.1. táblázat A vizsgálat dimenziói és indikátorai (és azok forrásai) ….................................... 102

6.2. táblázat A teljes vizsgált időszakra (2000-2015) kapott eredmények összefoglalása ......... 106

6.3. táblázat Az első időszakra (2000-2007) kapott eredmények összefoglalása ....................... 109

6.4. táblázat A második időszakra (2008-2015) kapott eredmények összefoglalása................... 110 
"[R]ecently unemployed young men are already taking on a significant share of the responsibility to make up for lost human capital acquisition opportunities resulting from their unemployment." (Mroz-Savage, 2006, 290. o.)

\section{BEVEZETÉS}

Az elmúlt években, különösen a 2007-2008-as recessziót követően egyre gyakrabban hallhattunk, olvashattunk az ifjúsági munkanélküliség (15-24 éves korosztályt érintő) kérdéséről. A probléma azonban nem új keletü, a válság inkább csak felerősítette. Ahogyan az Európai Unióban, úgy az Amerikai Egyesült Államokban is kiemelt figyelmet szentelnek annak a jelenségnek, hogy az oktatásból kikerülő fiatalok nehezen - vagy egyáltalán nem - találnak maguknak állást. Sőt, a fejlődő országokban is egyre jelentősebb a fiatalok körében a munkanélküliség, így joggal állíthatjuk, hogy globális problémáról van szó. A fejlett világban először az 1970-es évek válsága során, majd az 1980-as években került reflektorfénybe ez a kérdés, mivel az ún. „,baby-boom” generáció tagjai akkor érték el a munkavállalói kort (Artner, 2013; Bell-Blanchflower, 2010; Eurofound, 2012a; Williamson, 2009). Vitathatatlan, hogy maga a munkanélküliség rendkívül jelentős társadalmi és gazdasági probléma, éppen ezért a kezelése állandó feladat a törvényhozók számára. A munkanélküliség az egyéneket nagyon súlyosan érinti, ezáltal társadalmi feszültségeket idézhet elő (Nichols et al., 2013). A munkanélküliek körében magasabb a szegények aránya, továbbá a munkanélküliség a csökkenő (adó)bevételeken túl a költségvetési kiadások növekedését is eredményezi (a szociális támogatások, segélyek révén). Ebből kifolyólag magas (és hosszan tartó) munkanélküliség esetén a kormányok újabb adókat vethetnek ki a többletkiadások fedezése érdekében, amivel a foglalkoztatottak vásárlóerejét is csökkenthetik. Összességében a foglalkoztatás kedvezően hathat a gazdasági növekedésre (ahogyan a gazdasági növekedés is javíthatja a foglalkoztatást), míg a munkanélküliség (elsősorban az alacsony képzettségű munkanélküliek nagy aránya) gátolhatja azt, és inkább költségvetési többletterhet jelent. Ám látni kell azt is, hogy miért speciális a fiatalok munkapiaci helyzete, miért érdemes a teljes munkaerőpiac általános állapotán belül ezzel a csoporttal külön is foglalkozni. Ezért a dolgozatban az ifjúsági munkanélküliség jelenségével foglalkozunk, elsősorban az Európai Unió térségében.

Bár globális szinten a 25 éven aluliak részaránya a munkanélkülieken belül az elmúlt években fokozatosan csökkent (a 2004-es 41,5 százalékról 2014-ben 36,7 százalékra), még mindig jóval meghaladja azt a szintet, amelyet a fiatalok teljes népességen belüli aránya (1617\%) indokolna (ILO, 2015a). Ám a fiatalok munkanélküliségével nem csak azért foglalkoznak a közgazdászok és gazdaságpolitikusok, mert magasabb, mint az idősebbeké, hanem azért is, mert jellemzője, hogy időben elhúzódó, és mert tovagyürüző hatásai révén nem csak a fiatalokat 
érinti (Caporale-Gil-Alana, 2014). Emellett a magas ifjúsági munkanélküliség a meglévő erőforrások mobilizálásának hiányosságait tükrözi, és így a gazdaságok versenyképességének csökkenését mutatja (WEF, 2014).

A 2007-2008-as pénzügyi és gazdasági válság következtében az Európai Unió legtöbb országában minden korcsoportban ugrásszerüen megnövekedett az állástalanok száma. Az Eurostat (2017) adatai szerint 2007-ben közel 17 millió munkanélkülit regisztráltak az EU 28 országában, s ez a szám 2013-ra 26,3 millióra emelkedett. Ezt az évet követően kezdett csak el javulni ez a mutató, de a munkanélküliek száma még 2016-ban is meghaladta a 20,9 milliót. Az éves munkanélküliségi ráta 2007-ben még 7,2 százalék volt, ez 2013-ra 10,9 százalékra növekedett, majd 2016-ra lecsökkent 8,5 százalékra, amely még mindig meghaladta a válság előtti szintet. Az eurózónában e mutató értéke 2007-ben 7,5 százalék, 2013-ban 12,0 százalék, 2016-ban pedig 10,0 százalék volt - viszont ez országonként nagy eltéréseket mutatott, hiszen míg Németországban csupán 4,1 százalék, addig Görögországban 23,6 százalék volt 2016-ban.

Az európai fiatalok körében különösen magasnak tekinthető az állástalanok száma: 2007ben az EU-28-ban 4,2 millió 25 év alatti volt munkanélküli, 2013-ban 5,6 millió, 2016-ra pedig ismét lecsökkent hozzávetőleg 4,2 millióra. A fiatalok körében a munkanélküliségi ráta 2007ben 15,9 százalék, 2013-ban 23,7 százalék, 2016-ban pedig 18,7 százalék volt (az Amerikai Egyesült Államokban e mutató értéke rendre 10,5 százalék, 15,5 százalék és 10,4 százalék volt). Eközben a globális ifjúsági munkanélküliségi ráta 2007-ben 11,7 százalék, 2013-ban 13 százalék, 2016-ban pedig 13,1 százalék volt. Ez azt jelenti, hogy 2007-ben 70,5 millió, 2013ban 73,9 millió, 2016-ban pedig 71 millió 15-24 éves fiatal volt munkanélküli világszerte (ILO, 2015a; 2016a). Az Európai Unióban az ifjúsági munkanélküliség csökkentésére célirányos tagállami foglalkoztatáspolitikai lépések születtek, valamint számos uniós szintü kezdeményezés is létrejött, illetve a korábban is létezők nagyobb hangsúlyt kaptak. Az eddigi tapasztalatok alapján úgy tünik, hogy nemzeti szinten nagy szerepe van a fiatalokat megcélzó jól megtervezett aktív munkaerőpiaci eszközöknek, valamint az oktatási/képzési rendszer és a munkaerőpiac gyakornoki programokkal történő összekapcsolásának, uniós szinten pedig nagy hangsúlyt kap a mobilitás ösztönzése. Ezekhez az intézkedésekhez több ponton is kapcsolódnak a munkaerőpiaci rugalmasság különböző vetületeivel összefüggő kérdések.

A munkaerőpiaci flexibilitás szerepének megítélése az idők során többször változott, és a foglalkoztatásra gyakorolt hatásait illetően ma is megoszlanak a vélemények a közgazdászok körében, ezért számos empirikus kutatás irányul ezen összefüggések vizsgálatára. Dolgozatunk fő kutatási kérdése szintén ehhez kapcsolódik: kimutatható-e (a 2007-2008-as gazdasági válság által meghatározott környezetben) az Európai Unió országaiban szignifikáns 
kapcsolat a munkaerőpiaci rugalmasság mértéke és az ifjúsági munkanélküliség nagysága között? Ahhoz, hogy a fiatalok foglalkoztatásának növelését célzó, a válság alatt és azt követően hozott gazdaságpolitikai intézkedések eredményesek legyenek, elengedhetetlen a jelenség kiváltó okainak és a fiatalok munkapiaci helyzetének minél pontosabb ismerete. Ezért a dolgozat statisztikai elemzésének fókuszában a munkaerôpiaci rugalmasság dimenziói és az ifjúsági munkanélküliség alakulása közötti kapcsolat kérdése áll. Az elemzés során arra a kérdésre keressük a választ, hogy milyen összefüggés van a munkaerőpiaci rugalmasság egyes dimenziói és az ifjúsági munkanélküliség nagysága között, valamint, hogy azonosítható-e a munkaerőpiaci rugalmasság egyes dimenzióinak generációspecifikus hatása. Ezért az empirikus vizsgálat során a fiatalok mellett az idősebb korosztályokra vonatkozó adatokkal is dolgozunk, hogy láthatóvá váljanak az esetleges különbségek a korcsoportok között.

Az elméleti áttekintés során leszürt következtetéseink alapján három hipotézist fogalmaztunk meg, amelyeket a kutatás során vizsgálunk:

1. hipotézis: Az Európai Unióban a nagyobb rugalmasságú munkaerőpiacokon magasabb a fiatalok foglalkoztatottsága.

2. hipotézis: Az Európai Unió tagállamaiban nem jelentkezik a munkaerőpiaci rugalmasság generációspecifikus hatása, vagyis a fiatal és az idősebb korosztály foglalkoztatottságát nem befolyásolják eltérő mértékben a rugalmasság különböző dimenziói.

3. hipotézis: Az Európai Unió tagállamaiban az ifjúsági munkanélküliség nagysága és a munkaerőpiaci politikákra fordított állami költségvetési kiadások összege között nincs egyértelmü kapcsolat.

A dolgozat két nagyobb egységre tagolható. Az első rész (2-5. fejezet) a vizsgált téma elméleti megalapozását adja. A második rész (6. fejezet) saját empirikus elemzésünket mutatja be. Amikor az ifjúsági munkanélküliséggel foglalkozunk, fontos látni, hogy a (15-24 éves) fiatalok csoportja nem határolható le élesen a felnőtt népességtől, vagyis a munkaerőpiacok jellemzői egyaránt meghatározzák a fiatal és az idősebb korosztály foglalkoztatási kilátásait. A dolgozat ezért a következőképpen épül fel: a második fejezetben általában véve a munkanélküliség jelenségével foglalkozunk, ismertetjük a kapcsolódó fogalmakat és a fontosabb közgazdasági elméleteket. A harmadik fejezetben a munkaerőpiaci rugalmassággal foglalkozó szakirodalom eredményeit ismertetjük.

A negyedik fejezetben kifejezetten a fiatal korcsoportra fókuszálunk. Bemutatjuk az Európai Unióban tapasztalható teljes és ifjúsági munkanélküliség alakulását az elmúlt 
évtizedekben és kiemelten a válság éveiben. Szakirodalmi forrásokra támaszkodva rövid történeti áttekintést adunk az Unió munkaerőpiacainak jellemzőiről, emellett leíró statisztikai eszközök segítségével illusztráljuk a foglalkoztatottság alakulását az Unióban. Ennek során külön figyelmet szentelünk a fiatal korosztály helyzetének, valamint a 2007-2008-as válság szerepének. Emellett rávilágítunk a fiatalok közötti nagymértékű munkanélküliség egyéni, társadalmi és gazdasági következményeire, melyek súlyossága és időbeli elhúzódása egyértelműen indokolja a témaválasztásunk fontosságát. Ezt követően ismertetjük az ifjúsági munkanélküliség hátterében álló okokat és az ezeket vizsgáló szakirodalom megállapításait, kiemelve a munkaerőpiaci rugalmasság jelentőségét.

Mivel az Európai Unióban a tagállami politikákat kiegészítik az uniós szintü célkitüzések és politikák, ezért fontosnak tartjuk ezek ismertetését is. Ezért a dolgozat ötödik fejezetében bemutatjuk azokat az intézkedéseket, amelyeket az Európai Unió közösségi szinten valósított meg vagy tervez megvalósítani a fiatalok foglalkoztatásának növelése érdekében. Ezt követően bemutatjuk hét - valamilyen szempontból kiemelkedően teljesítő - Európai Uniós tagállam (Hollandia, Dánia, Németország, Egyesült Királyság, Svédország, Litvánia és Magyarország) sikeres ifjúsági foglalkoztatáspolitikai elemeit, valamint a válság - a fiatalok munkapiaci helyzetére gyakorolt - negatív hatásainak enyhítése érdekében foganatosított lépéseit. Ezen intézkedések jellege és eredményessége megmutatja a munkaerőpiaci rugalmasság és a foglalkoztatottság közötti elméleti összefüggések gyakorlati hasznosításának szükségességét.

A hatodik fejezetben ökonometriai elemzés (panel regresszió) alkalmazásával arra a kérdésre keressük a választ, hogy a munkaerőpiaci rugalmasság különböző vetületei milyen mértékben hatnak az ifjúsági munkanélküliség alakulására az Európai Unió országaiban. Megvizsgáljuk továbbá a rugalmasság dimenziói, valamint a fiatal és az idősebb korosztályok munkanélküliségi rátái közötti kapcsolatot is, hogy összevethessük az egyes korcsoportok közötti különbségeket. Egyúttal megkíséreljük megállapítani, hogy a munkaerőpiaci politikákra fordított állami költségvetési kiadások mennyiben befolyásolják az ifjúsági munkanélküliség alakulását. A dolgozatot lezáró hetedik fejezetben az összegző megállapítások ismertetése során megtörténik a korábban felvetett hipotézisek értékelése.

A kutatás és a dolgozat újszerüségét az adja, hogy aktuális, napjaink gazdaságpolitikai lépéseit meghatározó problémával foglalkozik, elméleti és gyakorlati szemszögből egyaránt. A munkapiaci rugalmasság irodalmán belül mindeddig kevés, kifejezetten a fiatalok foglalkoztatottságára fókuszáló vizsgálat született, ráadásul az évezred elején kialakult gazdasági válság olyan alapvető strukturális problémákra is ráirányította a figyelmet, amelyek módosíthatják a korábban elfogadott elméleti kereteket. 


\section{A MUNKANÉLKÜLISÉG ELMÉLETI MEGKÖZELÍTÉSE}

Az ifjúsági munkanélküliség jelenségével foglalkozva elengedhetetlen, hogy egyértelmüen tisztázzuk, mit értünk e fogalom alatt, illetve milyen más terminusokat kapcsolhatunk a témához. Magának a munkanélküliségnek az elméleti megközelítése sokat változott az idők során, tulajdonképpen ma sem létezik olyan elméletileg megalapozott és minden közgazdász által elfogadott definíció, amely teljes körüen leírná a jelenséget (Card, 2011). Ennek ellenére természetesen mindenkinek többé-kevésbé hasonló elképzelése van arról, hogy mit takar a fogalom. E fejezet célja az ifjúsági munkanélküliség témakörének felvezetése, és a munkaerőpiaci rugalmassággal vett kapcsolatának elméleti megalapozása. Ezért a következőkben először bemutatjuk a munkanélküliséggel kapcsolatos föbb közgazdasági fogalmakat és elméleteket, majd a munkanélküliség következményeinek ismertetésével foglalkozunk, melyek közül a legnagyobb hangsúlyt a gazdasági hatások kapják.

\subsection{A MUNKANÉLKÜLISÉGGEL KAPCSOLATOS FOGALMAK}

A munkanélküliség összetett jelenség, többféle lehet, és bár más-más elméleti magyarázat áll a munkanélküliség különböző típusainak hátterében, mégis szükség van egy jól használható „munkadefinícióra” (mutatóra), amely segíti a jelenség mérését. A Nemzetközi Munkaügyi Szervezet (International Labour Organization - ILO) azt az adott életkort betöltött embert tekinti munkanélkülinek, aki az adott héten nem dolgozott többet egy óránál, de keres munkát, amelyet azonnal meg is tudna kezdeni. ${ }^{1}$ Ez a munkanélküliség legáltalánosabb, globálisan elterjedt definíciója, mely nemzetközi összehasonlító vizsgálatokat is lehetővé tesz. Ez a gyakorlati megközelítésủ meghatározás az 1930-as évekre nyúlik vissza. Az első hasonló, a „munka keresésére” alapuló definíciót a New Deal keretében indított kutatási program (Works Progress Administration) és az Egyesült Államok Népszámlálási Hivatalának statisztikusai dolgozták ki - jóval megelőzve a neki teoretikus alapot adó keresési elmélet megjelenését (Card, 2011).

Adott időszakban a munkanélküliek számára vonatkozó adatokat az egyes országok statisztikai hivatalai teszik közzé. Az Európai Unióban elfogadott munkapiaci kategóriákat (2.1. ábra) az Eurostat (2014) kérdőíves munkaerő-felméréseiben (Labour Force Survey - EU LFS) szintén az ILO irányelveinek megfelelően határozza meg - és jelen dolgozatban is ezeket használjuk. Az EU LFS szerint egy ország népessége a munkaerőpiacon betöltött szerepe alapján két kategóriába sorolható: az aktívak és az inaktívak közé. A gazdaságilag aktív

\footnotetext{
${ }^{1}$ https://stats.oecd.org/glossary/detail.asp?ID=2791
} 
népesség vagy munkaerő két csoportja a foglalkoztatottak és a munkanélküliek. Az inaktívak sem foglalkoztatottak, sem munkanélküliek; lehetnek például diákok, háztartásbeliek, nyugdíjasok - lényegében, akik nem dolgoznak anyagi ellentételezésért és nem is keresnek munkát, vagy keresnek, de valamiért mégsem tudnának munkába állni.

2.1. ábra Egy ország lakosságának csoportjai a munkához füződő kapcsolatuk szerint

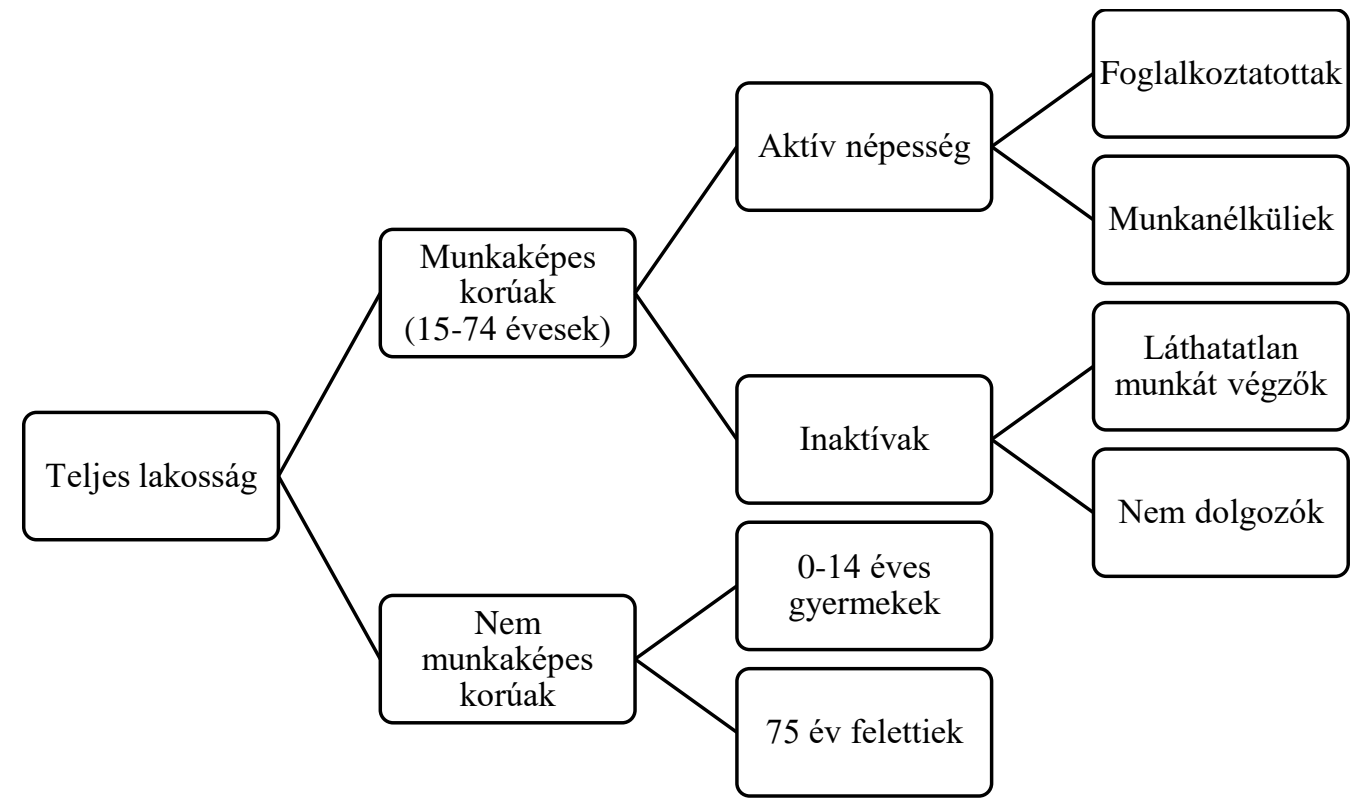

Forrás: saját szerkesztés.

Foglalkoztatott az a 15. életévét betöltött személy, aki a bázishéten akár csak egy órát is dolgozott fizetés, nyereség vagy családi haszon ellenében; vagy nem végzett munkát, azonban rendelkezik munkahellyel vagy vállalkozással, amelytől csak ideiglenesen maradt távol betegség, szabadság, munkaügyi vita, oktatásban vagy képzésben való részvétel miatt. ${ }^{2}$

Az ILO definíciójának is megfelelően munkanélküli az a 15 és 74 év közötti ${ }^{3}$ személy, aki megfelel a munkanélküliség hármas kritériumának, vagyis

- a referenciahéten nem dolgozott;

- az előző négy hét során aktívan keresett munkát;

- a következő két hétben munkába tudna állni (vagy már talált állást, amelyet a következö három hónapon belül be fog tölteni).

${ }^{2}$ Megjegyezzük, hogy ez a fogalom nem szerencsés abból a szempontból, hogy ez alapján az ember könnyen felülbecsülheti a munkából (meg)élök számát. Hiszen belátható, hogy aki egy héten csupán 1-2 órát dolgozik, az nem valószínü, hogy meg is tud élni abból a munkából. Hollandiában ezt a problémát kiküszöbölendő azokat tekintik foglalkoztatottnak, akik a referenciahéten legalább 12 órát dolgoztak (O’Higgins, 1997; Statistics Netherlands, 2015).

${ }^{3}$ Olaszországban, Spanyolországban, az Egyesült Királyságban, Izlandon és Norvégiában 16-74 év közötti személy (Eurostat, 2014). 
A dolgozatban ezt a fenti meghatározást alkalmazzuk a munkanélküliség leírására. E definíció nagy erénye, hogy lehetővé tesz nemzetközi összehasonlító vizsgálatokat a munkanélküliségre vonatkozóan, azonban könnyen belátható, hogy a valójában munka nélkül lévők száma eltér e mutató értékétől. A modern gazdaságokban mindig vannak munka nélkül lévő emberek, de ez nem azt jelenti, hogy ők mindannyian munkanélküliek lennének. Ahogyan Heyne et al. (2004) is rávilágít, az Amerikai Egyesült Államokban az emberek fele állástalan, mégis abszurd lenne az amerikaiak 50 százalékát munkanélkülinek titulálni. A gyermekeket és az időseket nem is tekintik munkaképes korúnak. De még a munkaképes korú lakosság egy jelentős része is olyan, hogy nem rendelkezik állással, azonban nem munkanélküli (és nincs is munka nélkül), hiszen úgynevezett láthatatlan munkát végez. Tipikusan láthatatlan munkának számítanak a háztartásban végzett feladatok, a gyermekek és idős vagy beteg családtagok gondozása, az önkéntes tevékenység különböző civil szervezetekben. Ezeknek közös jellemzője, hogy nem járnak munkaviszony létesítésével és a láthatatlan munkát végzők nem kapnak fizetést vagy bármilyen anyagi ellenszolgáltatást a munkavégzésükért (Daniels, 1987). Öket a gazdaságilag inaktívak csoportjába sorolhatjuk, azokkal együtt, akik bármilyen más okból nem kívánnak dolgozni. Közöttük jelentős az ún. reményvesztett vagy passzív munkanélküliek száma. Ök azok, akik bár szeretnének dolgozni, mégsem keresnek munkát, mert eleve reménytelennek látják az álláskeresést (Horváth-Hudomiet, 2005; Lakatos, 2012; O’Higgins, 1997). Éppen ezért az Eurostat kidolgozott három, úgynevezett kiegészítő munkanélküliségi mutatót (Eurostat, 2014; Lakatos, 2012):

1. munkát kereső, de azt azonnal megkezdeni nem tudó,

2. rendelkezésre álló, de munkát nem kereső, ${ }^{4}$

3. alulfoglalkoztatott részmunkaidős (másként: nem önkéntesen részmunkaidős).

E mutatók jövőbeli használata jelentősen árnyalhatja a munkaerőpiaci felmérések által festett képet, ám még így is maradnak rajta „homályos foltok”.

Az ENSZ definíciójának megfelelően fiatal munkanélkülinek a 15-24 év közötti munkanélkülieket tekintjük. ${ }^{5}$ Alapvetően nem értendők tehát közéjük a nappali rendszerü

${ }^{4}$ Az EU LFS munkanélküliség definíciója kiterjesztésének jogosságát alátámasztja Byrne és Strobl (2004) Trinidad és Tobago esetére végezett vizsgálata is, melyből kiderült, hogy az ILO definíciójában megkérdőjelezhető az aktív munkakeresés kritériumának jogossága. A szigetek munkaerő-felméréseit felhasználva a szerzők úgy találták, hogy azoknak a férfiaknak, akik az aktív munkakeresés nem teljesülése miatt számítanak gazdaságilag inaktívnak, indokoltabb lenne a munkanélküliek csoportjába tartozniuk. Ezt a megállapítást arra alapozzák, hogy az aktív munkakeresésnek vidéken (az agráriumban dolgozók esetében) nincs olyan jelentősége, mint a városokban.

${ }^{5}$ Egyes országok esetében lehet ettől eltérés. A fiatalok foglalkoztatását elősegítő programok az Egyesült Királyságban például a 16-18 éveseket célozzák meg, míg Észak-Olaszországban a 14-29 éveseket, DélOlaszországban pedig a 14-32 éveseket (O’Higgins, 1997). 
oktatásban résztvevő diákok (tanulók és hallgatók), hiszen ők gazdaságilag inaktívnak számítanak. Azonban vannak olyan diákok is, akik a teljes idejü képzés mellett is végeznek munkát, így van átfedés a munkapiac és az oktatás között (Eurostat, 2014). Az a fiatal például, aki a tanulás mellett aktívan keres munkát (és egyébként nincs neki), az bekerül az ifjúsági munkanélküliek csoportjába. Azonban az, aki nem dolgozik és nem is tanul, s eközben nem is keres aktívan munkát, nem tartozik ebbe a csoportba - ő gazdaságilag inaktívnak minősül (House of Lords, 2014).

Az ifjúsági munkanélküliség definíciójának hátránya lehet, hogy kizárólag azokat a gazdaságilag aktív fiatalokat fedi le, akik a referenciahéten nem dolgoztak, de kerestek munkát és el is tudnának kezdeni dolgozni. Ezt a problémát kiküszöbölendő született meg az 1970-es években a beszédesebb NEET (Not in Education, Employment or Training) mutató. Az angol mozaikszó a nem foglalkoztatott, oktatásban és képzésben nem részesülő 15-24 év közötti fiatalokat jelöli ${ }^{6}$ (Artner, 2013; Eurofound, 2012a). Közéjük tartoznak tehát a „klasszikus” munkanélkülieken kívül azok a gazdaságilag inaktívnak számító fiatalok is, akik bár nem is tanulnak és nem is dolgoznak, mégsem keresnek munkát (hasonlóan a passzív munkanélküliekhez). A NEET koncepció azért jött létre, hogy a fiatalok munkapiactól való elszakadását reprezentálja.

Amikor a munkaerőpiaci kategóriákról beszélünk, fontos nem csak a foglakoztatás tényét, hanem annak minőségét is szem előtt tartani. A kapitalista termelésre jellemző profitkényszer szorítása következtében a vállalatok nem minden esetben törekszenek a megfelelő munkakörülmények megteremtésére. Ez különösen a fejlődő országokban figyelhető meg, de a fejlettekben is előfordul, főként a nehezen ellenőrizhető területeken. Ezért az ILO 1999-ben megalkotta a tisztességes munka (decent work) koncepcióját (Ghai, 2003; ILO, 1999). ${ }^{7}$ Eszerint olyan munkalehetőségeket kell teremteni, amelyek (a foglalkoztatás, a szociális védelem, a munkavállalók jogai és a társadalmi párbeszéd négy komponensén belül) biztosítják:

- a tisztességes jövedelmet és munkahelyi biztonságot,

- a szociális védelmet a családok számára,

- a jobb kilátásokat a személyes fejlődés és a társadalmi integráció eléréséhez,

- a szabadságot az emberek számára, hogy kifejezzék véleményüket,

- a részvételt az életüket befolyásoló döntések meghozatalában,

\footnotetext{
${ }^{6}$ Artner (2013) cikkében a magyar „munkán, iskolán, képzésen kívüliek” fordítást és a MIKK rövidítést használja, de a dolgozatban továbbra is az elterjedtebb, angol NEET kifejezést alkalmazzuk.

${ }^{7}$ A tisztességes munka fogalmához kapcsolható a flexicurity koncepciója is, amellyel a 3.5. alfejezetben foglalkozunk bővebben.
} 
- az esélyegyenlőséget és az egyenlő bánásmódot minden nő és férfi számára.

A tisztességes munka koncepciója a jogszerütlen vagy szabálytalan foglalkoztatás (irregular employment) és a bizonytalan foglalkoztatás (precarious employment) visszaszorítására született meg. Ezek nem csak a fejlődő országokban léteznek, a fejlettekben is egyre elterjedtebbek. A szabálytalan foglalkoztatás kategóriája tágabb értelemben magában foglalja a bizonytalan foglalkoztatást is, és így nem csak szabálytalan, hanem atipikus foglalkoztatási formákat is kifejez (ILO, 20105a). A szabványos foglalkoztatás (standard employment) a leghagyományosabb értelemben vett munkaviszonyt, „szabályos munkaszerződést" jelenti, vagyis a teljes munkaidejü, határozatlan időre szóló, alkalmazotti (beosztotti) viszonyt. Ezen kívül azonban számos más, nem szabványos, bizonytalan vagy atipikus foglalkoztatási forma (non-standard forms of employment) is létezik (ILO, 2015b): ideiglenes munkaviszony; munkaerő-kölcsönzés és más szerződéses megállapodások; homályos foglalkoztatási viszonyok; szóbeli szerződések; valamint részmunkaidős foglalkoztatás. Ezek mind jellemzőek a rugalmas munkaerőpiacokon. A bizonytalan foglalkoztatás elterjedése az 1980-as évekre tehetö, kérdéseivel már az 1990-es évek elejétől foglalkoznak a kutatók, azonban igazán a 2007-2008-as válságot követően került reflektorfénybe (Prosser, 2015). Jellemzői a szerződéses bizonytalanságok; a meggyengült foglalkoztatási biztonság a munkavállalók számára; a nem szabványos (vagy atipikus) foglalkoztatási formák; valamint a be nem jelentett munka (Lavery, 2014; Prosser, 2015).

Standing (2011) szociológiai megközelítésü könyve szerint a bizonytalan foglalkoztatás gyökere a gazdasági verseny és versenyképesség növelésére irányuló törekvés, amely az 1970es években fogalmazódott meg. E cél érdekében ugyanis a neoliberális gazdasági modell szerint szükséges a munkaerőpiaci rugalmasság növelése, ami a foglalkoztatásban rejlő kockázatokat és bizonytalanságokat a munkavállalókra (és családjaikra) hárítja. Azok, akik ilyen körülmények között kénytelenek dolgozni, egy formálódó új társadalmi-politikai osztály, a prekariátus tagjai. A prekariátus fogalmának pontos meghatározása a nemzetközi szakirodalomban nem egységes. ${ }^{8}$ A prekariátus mint munkaerőpiaci csoport munkaerőpiaci helyzete egységesen instabil, bár emberi tőke tekintetében lényegesen különbözőek a tagjai (Sik-Szeitl, 2016) (fiatalok, idősek, migránsok, képzettek és képzetlenek egyaránt vannak közöttük [Szépe, 2012]), így ök is további csoportokra különíthetőek el.

A sebezhető foglalkoztatottak (vulnerable employment) a bizonytalan formákban foglalkoztatottak, mint az önfoglalkoztató dolgozók és a díjazás nélküli családi dolgozók

\footnotetext{
${ }^{8}$ A prekariátus konceptualizációjának nemzetközi szakirodalmáról összefoglalást ad Szépe (2012) cikke.
} 
(Artner, 2009; ILO, 2015a). Esetükben gyakorta jellemző a nem megfelelő jövedelem és a nehéz munkakörülmények, amelyek aláássák az alapvető jogaikat. Ide kapcsolható a feketevagy szürkegazdaságban dolgozók köre is, akik a felmérésekben vagy a regisztrált munkanélküliek, vagy az inaktívak csoportjába tartoznak. A szürkegazdaságban dolgozók közé sorolandók továbbá azok a foglalkoztatottak is, akik kevesebb munkaórára vagy egyszerüen alacsonyabb bérre vannak bejelentve, mint amennyi fizetést kapnak (legtöbbször a minimálbérre). Ők viszont a statisztikai felmérésekben nem gyarapítják a munkanélküliek számát. Hasonlóképpen bizonytalan foglalkoztatási feltételekkel és a szociális védelem hiányával jellemezhető az ideiglenesen foglalkoztatottak (temporary workers) egy csoportjának, az alkalmi bérmunkásoknak (casual wage labourers) a helyzete. Az alkalmi munkások alkalmazotti szerződésének időtartama 12 hónapnál rövidebb, és szólhat idénymunkára, alkalmi munkára, vagy egy előre rögzített feladat elvégzésére (ILO, 2015a). A bizonytalan foglakoztatásban állók között magas a dolgozó szegények aránya, vagyis azoké, akik napi 2 amerikai dollárnál kevesebből élnek. A (15-24 éves) dolgozó fiatalok egy része is ilyen körülmények között foglalkoztatott. 2013-ban a világon 169 millió fiatal volt dolgozó szegény (a napi 4 dollárnál kevesebből élő fiatalok száma pedig még magasabb, 286 millió volt) - többségük a fejlődő országokban él (ILO, 2015a).

A nem dolgozó és nem tanuló fiatalokat többféleképpen csoportosíthatjuk: (1) veszélyeztetett (vulnerable) és a nem veszélyeztetett NEET (Eurofound, 2012a); illetve (2) a munkaerőpiacra újonnan belépők (poorly-integrated new entrants), és a „hátrahagyott fiatalok" (left behind youth) (OECD, 2010). A veszélyeztetett fiatalok szociális, kulturális és humán tőkéje alacsony színvonalú, ezért őket valóban fenyegeti a gazdasági-társadalmi marginalizálódás veszélye. A „nem veszélyeztetett” csoport előnyösebb helyzete általában az anyagi biztonságot nyújtó családi háttérre vezethető vissza. A Gazdasági Együttmüködési és Fejlesztési Szervezet, az OECD (2010) csoportosítása szerint a munkaerőpiacra újonnan belépők azok, akik nehezen találnak munkát és az is sokszor csak ideiglenes; a ,hátrahagyott fiatalok" pedig azok, akik eleve nem is kerülnek közel a munkaerőpiachoz, s általában nem rendelkeznek magasabb fokú végzettséggel, sok esetben bevándorlók gyermekei, vagy elmaradott, leszakadó területeken élnek.

Érdemes még elkülöníteni a korai iskolaelhagyókat (akik középfokú végzettséget sem szereznek) és az alacsonyabb végzettségü fiatalokat a frissdiplomásoktól, hiszen a két csoportot eltérő tulajdonságok jellemzik. A frissdiplomások magas fokú végzettséggel rendelkeznek, mégis sokszor nehezen találnak állást, elsősorban a szakmai tapasztalat hiánya miatt, vagy azért, mert a munkapiac igényeinek nem megfelelő képzésben vettek részt. A korai 
iskolaelhagyók és a középfokú végzettséggel rendelkező fiatalok egy része képzetlen munkaerőt képvisel, ezért találnak nehezen állást, és legtöbbször az is bizonytalan. A fiatalok e csoportjának egy része az előbbi tipizálás szerinti „veszélyeztetett” és „hátrahagyott” kategóriákba sorolható.

A munkanélküliség mérésére, a munkapiac állapotának bemutatására többféle indikátor használatos, melyek közül a legáltalánosabbak a következők (Artner, 2013; Eurostat, 2017; OECD.Stat, 2017):

- az aktivitási ráta, amely a gazdaságilag aktívaknak a népességhez viszonyított százalékos aránya;

- a foglalkoztatási ráta, amely a foglalkoztatottaknak a népességhez viszonyított százalékos aránya;

- a munkanélküliségi ráta, amely a munkanélkülieknek a gazdaságilag aktív népességhez viszonyított százalékos aránya;

- a munkanélküliségi arány, amely a munkanélkülieknek a munkaképes korú (aktív és inaktív) népességhez viszonyított százalékos aránya;

- az ifjúsági foglalkoztatási ráta: a 15-24 év közötti foglalkoztatottaknak a 15-24 év közötti népességhez viszonyított százalékos aránya;

- az ifjúsági munkanélküliségi ráta (youth unemployment rate): a 15-24 év közötti munkanélkülieknek a gazdaságilag aktív 15-24 év közötti népességhez viszonyított százalékos aránya.

Ez az érték jellemzően magasabb, mint a teljes munkanélküliségi ráta, mivel a fiatalok jelentős része még teljes idejü oktatásban vesz részt, tehát gazdaságilag inaktív (Artner, 2013). Különösen igaz ez a fejlett országokban, ahol általában magasabb az oktatásban résztvevők aránya, és a fiatalok jellemzően hosszabb ideig is tanulnak, mint a kevésbé fejlett országokban. Az adatok elemzésekor ezt a tényt mindig szem előtt kell tartani.

- Az ifjúsági munkanélküliségi arány (youth unemployment ratio): a 15-24 év közötti munkanélkülieknek a 15-24 év közötti (aktív és inaktív) népességhez viszonyított százalékos aránya;

- a NEET ráta: a nem foglalkoztatott, oktatásban és képzésben nem részesülő 15-24 év közöttieknek a 15-24 év közötti (aktív és inaktív) népességhez viszonyított százalékos aránya;

- a fiatal (15-24 év közötti) munkanélküliek aránya a munkanélküliek teljes körén (15-74 évesek) belül; 
- az ifjúsági munkanélküliség relatív súlya (RIM): a 15-24 éves munkanélkülieknek az összes munkanélkülieken belüli aránya elosztva a 15-24 éves korosztálynak a 1574 éves korosztályon belüli arányával;

- a prekariátus összes foglalkoztatotton belüli aránya;

- a sebezhető foglalkoztatottak aránya az összes foglalkoztatotton belül;

- a dolgozó szegények összes foglalkoztatotton belüli aránya.

Ezeken felül természetesen a különböző munkaerőpiaci kategóriákba tartozók száma és annak időbeli alakulása is beszédes mutató.

\subsection{A MUNKANÉLKÜLISÉG OKAI, ELMÉLETEI}

A munkanélküliség kialakulásának okait régóta és sok nézőpontból vizsgálják a közgazdászok. Ennek megfelelően számos elmélet is létrejött a jelenség magyarázatára, amelyek között megfigyelhetők átfedések. Ebben az alfejezetben ismertetjük a munkanélküliség kialakulásának és fennmaradásának a különböző közgazdasági elméletekkel alátámasztott okait.

Makroökonómia címü tankönyvében Williamson (2009, 582-585. o.) a munkanélküliséget meghatározó makro szintü tényezőket négy nagyobb csoportba sorolja:

1. Az aggregált gazdasági teljesítmény meghatározza a foglalkoztatás szintjét, ennek megfelelően a munkanélküliség kontraciklikus változó.

2. A népesség korösszetétele, a demográfiai folyamatok szintén jelentőséggel bírnak. Az elöregedő társadalmakban alacsonyabb lehet a munkanélküliség, mint azokban az országokban, ahol a gazdaságilag aktív korú népesség aránya magasabb.

3. Az állami szabályozás többféle módon hathat a munkanélküliségre. A munkanélküli segélyezés rendszerének, a helyettesítési arány (a segély és a korábban keresett bér aránya) szerepének vizsgálatával számos empirikus kutatás foglalkozik. Ezek alapgondolata, hogy a relatíve nagy összegü munkanélküli segély és a munkanélküliként rendelkezésre álló többlet szabadidő együttesen többet ér az ember számára, mint a korábban megkeresett (illetve a jövőben elérhető) munkabére, akkor tudatosan dönthet úgy, hogy nem keres állást. Másrészt a munkavállalók védelmének erős állami szabályozása (például az elbocsátások megnehezítése, megdrágítása a munkáltató számára) arra ösztönzheti a munkaadókat, hogy fellendülés esetén attól elmaradó mértékben bővítsék a dolgozói létszámot, így recesszió idején kevésbé kell tartaniuk a leépítés költségeitől.

4. A szektorális átrendeződések, vagyis a gazdaság termelési szerkezetének megváltozása - legalább átmenetileg - ugyancsak hatással van a foglalkoztatás 
alakulására. A gazdasági fejlődés során jellemző, hogy csökken a mezőgazdaságban és/vagy az iparban foglalkoztatottak aránya, ám a szolgáltatási szektor munkakereslete nem szívja fel azonnal a kieső munkaerőt.

E tényezők mellett nagy jelentősége van a mikro szinten megjelenő okok azonosításának is. Hiszen a munkanélküliség az egyéneket érintő jelenség, és bár mindenkinek saját, egyedi története van, mégis megállapíthatók olyan, az egyes embereket jellemző tulajdonságok, élethelyzetek, amelyek következtében növekszik a munkanélkülivé válás valószínűsége. Tipikusan ilyen, munkaerőpiaci szempontból hátrányos helyzetű csoportok az alacsony iskolai végzettségüek ${ }^{9}$, a kisebbséghez tartozók (Magyarországon a roma népesség tagjai), a megváltozott munkaképességủ és fogyatékossággal élő emberek (ide érthetjük a rossz egészségi állapotúakat is), az elmaradott térségek lakói, valamint a nők, a fiatalok és az idősebb munkavállalók is nagyobb eséllyel lehetnek munkanélküliek. Mindamellett ezen egyéni jellemzők többnyire visszavezethetőek makro (társadalmi) szintű okokra.

Megkülönböztetünk, és érdemes is elkülönítve kezelni a hosszú távú (egy évnél hosszabb ideje fennálló) és a rövid távú munkanélküliséget, hiszen más-más tényezők áll(hat)nak ezek hátterében, és a hatásuk is eltérő (lehet). A munkaerőpiacra újonnan belépő fiatalok egy jelentős része például tipikusan rövid idő (néhány hónap) alatt talál magának állást. Ez nem jelent számukra különösebb problémát, viszont ha valaki egy éven túl sem tud elhelyezkedni a munkaerőpiacon, az az anyagi nélkülözésen túl súlyos önértékelési és egyéb pszichológiai nehézségeket élhet meg. ${ }^{10}$

Makro szintü megközelítésben hosszú távon szokás beszélni a munkanélküliség természetes vagy egyensúlyi szintjéről, amely mindig nagyobb, mint nulla, és egyrészt súrlódásos vagy frikciós munkanélküliségből, másrészt strukturális munkanélküliségből áll össze. A súrlódásos vagy frikciós munkanélküliség a munkakeresésből és annak elhúzódásából következik. Ez azért fordul elő, mert az emberek időnként munkahelyet változtatnak (például a gazdaság szerkezeti változásai vagy egyéni preferenciáik miatt), újonnan lépnek be a munkaerőpiacra vagy kilépnek onnan. Vagyis ez általában egy rövid, átmeneti időszakot jelent az ember életében. Az ebben a helyzetben lévők önkéntesen vállalják a munkanélküliséget olyan értelemben, hogy a munkapiacon adott bér mellett nem akarnak munkát vállalni (Mankiw, 2011; Samuelson-Nordhaus, 2012). Nehéz azonban objektív módon

\footnotetext{
${ }_{9}$ Öry $(2005,20$. o.) szerint ,, alacsony végzettségüeknek tekinthetjük egyrészt azokat, akik még az általános iskolát sem fejezték be, másrészt a munkaerőpiac szereplőinek azon tagjait, akik ugyan elvégezték az általános iskolát, ugyanakkor ezen kívül semmilyen végzettséget nem szereztek, azaz szakma nélkül szintén kevés esélyük van az elhelyezkedésre".

${ }^{10}$ A kifejezetten a fiatal korcsoportot érintő hatásokkal a 4.2. alfejezetben foglalkozunk részletesen.
} 
meghatározni e természetes munkapiaci mozgások nagyságát, már csak azért is, mert időben jelentős változékonyságot mutatnak (Heyne et al., 2004).

A strukturális - nem önkéntes - munkanélküliség abból adódik, hogy a munkakínálat és munkakereslet szerkezete eltérő (Samuelson-Nordhaus, 2012). ${ }^{11}$ Tipikusan a hanyatló szakmákban vagy régiókban állást keresők tartoznak a strukturális munkanélküliek közé. Az egyensúlyi bérnél magasabb béreket és így a hosszú távú, strukturális munkanélküliséget eredményező makrogazdasági okok továbbá a minimálbér, a szakszervezetek tevékenysége és a hatékony bérek (Mankiw, 2011). A minimálbér-szabályozás nagymértékben az alacsony képzettségü és munkatapasztalattal nem rendelkező - fiatal - munkavállalókat érinti. Hiszen ha a jogszabályok által rögzített minimálbér magasabb, mint amekkorát a munkáltatók önszántukból fizetnének (a munka határterméke, valamint a gazdasági lehetőségek alapján), akkor a munkaadók igyekeznek ugyanakkora termelést kevesebb foglalkoztatottal elérni. Ezt pedig a tapasztalt munkavállalókkal lehet egyszerübben biztosítani. (Gazdasági konjunktúra esetén ez a hatás értelemszerüen visszafogottabb, vagy nem is jelentkezik.) Mindez arra vezethető vissza, hogy a vállalatok müködésének végső célja a lehető legnagyobb profit termelése. A szakszervezetek a kollektív alkuk során igyekeznek minél magasabb bért kiharcolni a munkaadóktól, ezért szintén képesek az egyensúlyinál magasabb bérszintet előidézni, ráadásul nem csupán a szakszervezeti tagok, hanem a vállalat többi munkavállalója számára is. Tehát ebben az esetben is a minimálbér-szabályozáshoz hasonló eredményre jutunk. Végül a hatékony bérek elmélete ${ }^{12}$ szerint a vállalatok hatékonyabb müködését segíti, ha azok az egyensúlyi szintnél (vagyis a határtermék-bevételnél) magasabb béreket kínálnak, mivel a magasabb fizetés következtében javul a dolgozók egészségi állapota, kisebb hajlandóságot mutatnak a munkahely elhagyására, és készek több erőfeszítést tenni a vállalat sikere érdekében, így növekszik a munkavállalók hatékonysága, termelékenysége. Továbbá az elmélet szerint a magasabb bért kínáló cég eleve jobb képességü dolgozókat tud alkalmazni. Mindez ahhoz vezet, hogy kevesebb munkavállalóra lesz szüksége a vállalatnak. A különbség, hogy a minimálbér és a szakszervezetek tevékenysége nyomán kialakult relatíve magas bérek a vállalat számára adottságként jelentkeznek, egyfajta kényszerhelyzetet teremtve, míg a hatékony béreket a menedzsment szabadon alkalmazza.

A hagyományosan rövid távúként értelmezett - napjainkban azonban egyre hosszabbra nyúló és esetenként strukturálissá váló - ciklikus vagy konjunkturális munkanélküliség a

\footnotetext{
11 Hazánkban is jól ismert jelenség, hogy bizonyos végzettségü munkavállalókból túlkínálat van a munkaerőpiacon (azonban ezzel párhuzamosan vannak hiányszakmák is, ezekben az esetekben felkészültséghiányról beszélhetünk).

${ }^{12}$ A hatékony bérek elméletéröl lásd például Katz (1986).
} 
tényleges és a természetes (egyensúlyi) szint közötti eltérés. Az aktuális gazdasági trendekhez igazodik, oka a gazdasági visszaesés, a dolgozók (sokszor tömeges) elbocsátása. Ezt a gazdasági ciklusok keynesi elmélete írja le, kiemelve a ragadós bérek jelentőségét (Mankiw, 2011; Samuelson-Nordhaus, 2012, 541-542. o.; Williamson, 2009, 430-434. o.). Mindezeket az okokat a 2.1. táblázat foglalja össze.

2.1. táblázat A munkanélküliség okai

\begin{tabular}{|c|c|c|}
\hline $\begin{array}{l}\text { A munkanélküliség } \\
\text { időtartama }\end{array}$ & Okok szintje & Okok \\
\hline \multirow[t]{2}{*}{$\begin{array}{l}\text { Hosszú távú } \\
\text { munkanélküliség }\end{array}$} & Makro szintü okok & $\begin{array}{l}\text { - aggregált gazdasági teljesítmény } \\
\text { - a munkakínálat és -kereslet eltérő szerkezete } \\
\text { (strukturális munkanélküliség) } \\
\text { - állami szabályozás } \\
\text { - egyensúlyinál magasabb bér (minimálbér, } \\
\text { szakszervezetek, hatékony bérek) } \\
\text { - demográfiai folyamatok }\end{array}$ \\
\hline & Mikro szintű okok & $\begin{array}{l}\text { - alacsony iskolai végzettség } \\
\text { - rossz egészségi állapot } \\
\text { - elmaradott térség }\end{array}$ \\
\hline \multirow[t]{2}{*}{$\begin{array}{l}\text { Rövid távú } \\
\text { munkanélküliség }\end{array}$} & Makro szintü okok & $\begin{array}{l}\text { - munkapiaci mozgások, a gazdaság szerkezeti } \\
\text { változásai (frikciós munkanélküliség) } \\
\text { - gazdasági visszaesés (ciklikus, konjunkturális } \\
\text { munkanélküliség) }\end{array}$ \\
\hline & Mikro szintü okok & - egyéni preferenciák \\
\hline
\end{tabular}

Forrás: saját szerkesztés.

A munkanélküliség elméleti hátterének vizsgálatával foglalkozó közgazdasági modellek számos variációja (2.2. táblázat) jött létre az idők során, melyek egyes elemei fennmaradtak, mások felülíródtak. A következőkben ezekről adunk egy rövid áttekintést.

Mint az közismert, a klasszikus közgazdaságtan képviselői (például Pigou és Solow) szerint a munka kereslete és kínálata határozza meg a munkaerőpiaci folyamatokat, egyensúlyi reálbér mellett pedig megvalósul a teljes foglalkoztatás. Ebben a helyzetben csupán a frikciós vagy önkéntes munkanélküliség jelentkezik, amely a rendelkezésre álló információk, a jobb munkahely keresése, valamint a munkakereslet véletlenszerü változásai következtében merül fel és időbeli elhúzódása a munkanélküli ellátásoktól és az információáramlás sebességétől függ (Mouhammed, 2011). Ugyanezt a gondolatot követték a neoklasszikus közgazdaságtan alakjai (például Walras vagy Marshall). A munkapiacot tehát egy zárt, önmüködő homogenitás és teljes informáltság jellemezte - rendszernek tekintették, amelyben a dinamikus egyensúlyt alapvetően a munkaadók és munkavállalók egymással szembenálló érdekeinek megfelelően kialakuló reálbér teremti meg (Balcsók, 2005; Morvay, 2012). 
2.2. táblázat Közgazdasági elméletek a munkanélküliségről

\begin{tabular}{|c|c|c|}
\hline EImélet & Megjelenés & Munkanélküliség oka \\
\hline $\begin{array}{l}\text { Neoklasszikus } \\
\text { közgazdaságtan }\end{array}$ & 1870-es évek & $\begin{array}{l}\text { csak frikciós vagy önkéntes munkanélküliség lehet, oka az } \\
\text { információáramlás időszükséglete, és a munkakereslet } \\
\text { véletlenszerü változásai }\end{array}$ \\
\hline John M. Keynes & 1930-as évek & $\begin{array}{l}\text { elégtelen aggregált kereslet, a beruházási kiadások } \\
\text { elmaradása }\end{array}$ \\
\hline Milton Friedman & 1950-es évek & $\begin{array}{l}\text { önkéntes munkanélküliség: a munkavállalók a piacon } \\
\text { érvényes bér ellenében nem kívánnak dolgozni; } \\
\text { strukturális munkanélküliség: az állam és a } \\
\text { szakszervezetek tevékenysége révén kialakuló túl magas } \\
\text { bérszínvonal; } \\
\text { a természetes ráta függ a munka- és árupiac strukturális } \\
\text { jellemzőitől, a piaci tökéletlenségek mértékétől, a kereslet } \\
\text { és kínálat ingadozásaitól, valamint az információszerzés } \\
\text { és a mobilitás költségétőll }\end{array}$ \\
\hline Schumpeter & 1940-es évek & elmaradó innovációk \\
\hline $\begin{array}{l}\text { Szegmentált } \\
\text { munkaerőpiaci } \\
\text { elméletek }\end{array}$ & 1960-as évek & $\begin{array}{l}\text { institucionalista (és neoinstitucionalista) elmélet: az } \\
\text { állami beavatkozás, a bürokratikus szervezetek és a } \\
\text { szakszervezetek müködése; } \\
\text { duális-szegmentált munkaeröpiac elmélete: eltérö } \\
\text { fizetések és munkakörülményeik a két részpiacon; } \\
\text { diszkrimináció elmélete: családi háttér, társadalmi- } \\
\text { politikai szféra, állami gazdaságpolitika, területfejlesztési } \\
\text { prioritások diszkrimináló hatásai }\end{array}$ \\
\hline Keresési modellek & 1970-es évek & a munkakínálati oldalon jellemző keresési súrlódások \\
\hline $\begin{array}{l}\text { Keresési-párosítási } \\
\text { modellek }\end{array}$ & 1980-as évek & $\begin{array}{l}\text { az üres álláshelyek és a munkavállalók heterogenitása, a } \\
\text { piacot jellemzó súrlódások és az információgyưujtés } \\
\text { nehézségei }\end{array}$ \\
\hline $\begin{array}{l}\text { Strukturalista } \\
\text { megközelítés }\end{array}$ & 1980-as évek & $\begin{array}{l}\text { a munkanélküliségi ráta egyensúlyozza ki a bér- és } \\
\text { ármeghatározó szereplők egymással szembenálló } \\
\text { követeléseit }\end{array}$ \\
\hline $\begin{array}{l}\text { Reál üzleti ciklusok } \\
\text { elmélete }\end{array}$ & 1980-as évek & $\begin{array}{l}\text { a technológiai sokkok hiánya, a teljes } \\
\text { tényezőtermelékenység javulásának elmaradása }\end{array}$ \\
\hline
\end{tabular}

Forrás: saját szerkesztés.

Azonban a világháború és az 1929-33-as nagy világgazdasági válság következtében kialakult óriási munkanélküliség ebben a formájában megdöntötte ezt az elméletet (Farkas, 2007). Válaszként az 1930-as évektől John Maynard Keynes a gazdasági szereplők körében az optimista hangulat fenntartásának fontosságát és ennek érdekében az állami keresletélénkítés, a költségvetési politika szerepét hangsúlyozta, mivel szerinte a munkanélküliség kényszerü és ciklikus, és az elégtelen aggregált keresletnek, különösen a beruházási kiadások elmaradásának köszönhető. A hatékony kereslet elméletéhez kapcsolható még Thorstein Veblen neve is. A vállalatok célja a profit növelése, és Veblen szerint ennek elérése érdekében az aggregált kereslet figyelembe vételével a cégek igyekeznek növekedni és ehhez több alkalmazottra van szükségük - ennek következtében pedig csökken a munkanélküliség (Mouhammed, 2011). 
Az 1950-es éveket követően Milton Friedman viszont már a monetáris politika ciklikus ingadozásokat csökkentő szerepét emelte ki (ahogyan a Phillips-görbe is ábrázolja). Friedman emellett kidolgozta a munkanélküliség természetes rátájának elméletét is, amely szerint a munkanélküliség vagy önkéntes, mert abból fakad, hogy a munkavállalók a piacon érvényes bér ellenében nem kívánnak dolgozni; vagy az állam és a szakszervezetek tevékenysége révén kialakuló túl magas bérszínvonal okozza. Ebben a dinamikus megközelítésben a természetes ráta az, amelyhez a gazdaság hosszú távon konvergál, de ez a ráta időben nem állandó, mivel függ a munka- és árupiac strukturális jellemzőitől, a piaci tökéletlenségek mértékétől, a kereslet és kínálat ingadozásaitól, valamint az információszerzés és a mobilitás költségeitől (Morvay, 2012).

Ez idő tájt egyre nagyobb szerepet kapott az innovációkkal összefüggésben Schumpeter munkássága (1942), a „teremtő rombolás” gondolata (Mouhammed, 2011). E szerint a gazdasági fejlődés és az az innováció, amely több munkahelyet hoz létre, mint amennyi megszünik a bevezetése következtében, az egyik legnagyobb foglalkoztatást növelő erö. Azonban ha az innovációk elmaradnak, akkor más vállalatok is elkezdik másolni az újításokat, így az alapanyagok kereslete és ára emelkedni fog, aminek következtében megnövekednek a termelési költségek, miközben a növekvő kínálat miatt a késztermék ára csökken. Mindez a profit elmaradásához, s ezáltal a foglalkoztatás csökkenéséhez vezet.

Fontos tény, hogy empirikus tapasztalatok alapján munkanélküliség egyensúlyban is létezik. Ennek oka pedig, ahogyan a szegmentált munkaerőpiaci elméletek képviselői felismerték, hogy a munkaerőpiac nem homogén, így alakulhatnak ki a tartós jövedelmi különbségek, a munkaeröpiaci diszkrimináció, vagy a munkanélküliség egyenlőtlen eloszlása. Tóthné Sikora (2002) három szegmentált munkaerőpiaci elméletet nevez meg legjelentősebbnek: az institucionalista, a duális-szegmentált elméletek és a diszkrimináció elmélete. Az institucionalista (és neoinstitucionalista) elmélet szerint a modern gazdaságokban az állami beavatkozás, valamint a bürokratikus szervezetek és a szakszervezetek müködése teszi tökéletlenné a munkapiaci versenyt. A duális-szegmentált munkaeröpiac elméleteinek alapja, hogy a munkapiac két (primer és szekunder) részpiacból áll: a primer szegmensbe tartoznak a nagyvállalatok és/vagy a szervezett szakmák dolgozói, akiknek a fizetése viszonylag magasabb és jobbak a munkakörülményeik; a szekunder szegmensben ezzel ellentétben alacsonyabb fizetés, rosszabb körülmények és a munkahelyi stabilitás hiánya jellemző. A diszkrimináció elméletének alapja, hogy az esélyegyenlőség nem érvényesül a munkapiacokon (sem). Arrow 1973-as, „A diszkrimináció elmélete” címü munkájában a diszkriminációt úgy definiálja, hogy a munkaerő a termelékenységétől független jellemzői 
alapján értékelődik a munkaerőpiacon, ami a bérekben és a munkaerő-felvételben egyaránt megnyilvánul (Polónyi, 2002). A családi háttér, a társadalmi-politikai szféra, de az állami gazdaságpolitika és a területfejlesztési prioritások egyaránt diszkrimináló tényezők lehetnek.

A tökéletesen versenyző piacokra jellemző teljes informáltság életszerütlen feltételét a keresési modellek az 1970-es évek elején oldották fel (lásd Rogerson et al., 2005). Ezek középpontjában a munkakínálati oldalon jellemző keresési súrlódások állnak, ami azt jelenti, hogy az álláskeresők az egyes cégek által kínált bérek pontos ismeretének hiányában egy bizonyos ideig keresik a számukra megfelelő ajánlatot és visszautasítják az alacsony (a rezervációs bérüknél alacsonyabb) bért kínáló állásajánlatokat - ez okozza a munkanélküliséget (Morvay, 2012). A keresési modellekre épülnek a napjainkban leginkább meghatározó keresési-párosítási modellek, amelyek már a munkakeresleti oldali súrlódásokat is figyelembe veszik, tehát nem egyszerüen a túlkínálat jelenségére vezetik vissza a munkanélküliséget. 2010ben Peter Diamond, Dale Mortensen és Christopher Pissarides e modellek megalapozásáért („for their analysis of markets with search frictions”) részesültek Nobel-díjban. $\mathrm{Az}$ alapmodellben a munkapiac decentralizált, a vállalatok munkaerőt keresnek, a munkavállalók munkát kínálnak. Az üres álláshelyek és a munkavállalók heterogenitása, a piacot jellemző súrlódások és az információgyüjtés nehézségei miatt a megfelelő partner felkutatása időbe és pénzbe kerül. A megkötött új munkaszerződések számát a modellekben a párosítási (matching) függvény adja meg. Fontos jellemző emellett a keresési externáliák jelenléte, valamint a súrlódások következtében jelentkező állásteremtési járadék (amely a munkavállaló és a vállalat várt keresési költségeinek összegével egyenlő) (Morvay, 2012). A modellek kiterjesztik a munkanélküliség természetes rátájának elméletét, így képesek a jóléti intézkedések és intézményrendszer beépítésére.

A munkaerőpiacok tökéletlenségeinek felismerése következtében az 1980-as évektől a makroökonómiai elméletek mikroökonómiai alapjai megerősödtek, és a parciális elemzések helyett általános egyensúlyi keretben folyik a gondolkodás (Beissinger-Moeller, 2000). Emiatt terjedt el az aggregált munkanélküliség magyarázatának strukturalista megközelítése, amelynek kiinduló feltételezése a tökéletlen verseny a munka- és termékpiacon, és amely szerint a munkanélküliségi ráta egyensúlyozza ki a bér- és ármeghatározó szereplők (a szakszervezetek és munkavállalók valamint a profitmaximalizáló cégek) egymással szembenálló követeléseit. Az 1980-as évek elején az újklasszikus makroökonómia áramában született reál üzleti ciklusok elméletében a teljes tényezőtermelékenység alakulása meghatározó (Lőrincz, 2000). Ha a technológiai ugrások, sokkok elmaradnak, akkor a tényezőtermelékenység sem javul, így növekszik a munkanélküliség. Mikroökonómiai 
megközelítés szerint a tökéletesen versenyző piacon a munka kereslete a termelékenységétől függ, a munkakeresleti és munkakínálati függvények metszéspontja meghatározza a bért és a foglalkoztatást. Ebben a pontban a munka határtermék értéke egyenlő a bérrel. Tökéletlen (oligopolisztikus) verseny esetén azonban a munkakereslet a határtermék-bevételtől függ, amely alacsonyabb, mint a munka határtermék értéke (mivel a határbevétel kisebb a piaci árnál). Ilyenkor az alacsonyabb kibocsátás következtében a foglalkoztatás is alacsonyabb, mint tökéletes verseny esetén. A termelékenység és a munkanélküliség kapcsolatát vizsgáló mikroökonómiai elméletben a munka termelékenységének (vagy a munka átlagtermékének) növekedése állandó (vagy kisebb ütemben növekvő) bérek mellett növeli a profitmaximalizáló vállalatok munkakeresletét, és így a foglalkoztatást (Mouhammed, 2011).

\subsection{A GAZDASÁGI NÖVEKEDÉS ÉS A MUNKANÉLKÜLISÉG KAPCSOLATA}

A foglalkoztatottság és a munkanélküliség nagysága mindig fontos kérdés egy országban. Ezek ugyanis az egyéneket nagyon súlyosan érintik, ezáltal társadalmi feszültségeket idéznek elő (Nichols et al., 2013). A munkanélküliek körében magasabb a szegények aránya. A munkanélküliség kedvezőtlen hatása a csökkenő (adó)bevételeken túl a költségvetési kiadások növekedését is eredményezi (a szociális támogatások révén). Ennek következtében magas (és hosszan tartó) munkanélküliség esetén a többletkiadások fedezése érdekében a kormányok újabb adókat vethetnek ki, amellyel a foglalkoztatottak vásárlóerejét is csökkenthetik. Természetes, hogy a munkapiaci helyzetre nagy hatással van a gazdaság általános állapota. Ami a változásokat illeti: a foglalkoztatás kedvezően hathat a gazdasági növekedésre, és bár vannak ellenpéldák, az is viszonylag általánosan elfogadott, hogy a gazdasági növekedés is javíthatja a foglalkoztatást. A továbbiakban e két tényező kapcsolatával foglalkozunk, mégpedig azért, mert a közelmúltban ezen a téren változásokat figyelhettünk meg.

A munkanélküliségi ráta és a gazdasági kibocsátás közötti negatív kapcsolat régóta ismert jelenség. Azonban ennek a kapcsolatnak az erőssége már kevésbé egyértelmü. Az áru- és munkapiac ilyenfajta összekapcsolását adja Okun törvénye, melynek egyszerüsített formája leírja, hogy a GDP potenciális (vagyis teljes foglalkoztatottság esetén elérhető) szintjéhez viszonyított 2 százalékos visszaesése esetén a munkanélküliségi ráta hozzávetőleg 1 százalékponttal növekszik. Ez alapján elegendő lehetne a gazdasági növekedés elősegítésére koncentrálni, a munkanélküliség csökkenése pedig ezzel párhuzamosan magától végbemenne. Arthur M. Okun vizsgálatait az 1960-as években végezte, s bár eredményeit azóta sok kritika érte, még napjainkban is ad kutatási kérdéseket és számos újabb változata is született (Máté, 2010). Mások mellett Knotek (2007), valamint Owyang és Sekhposyan (2012) elemzései 
rávilágítanak, hogy Okun törvénye és annak különböző változatai nem szoros és időben állandó kapcsolatot írnak le a gazdasági növekedés és a munkanélküliség változása között: nagy jelentősége van például az adott gazdaság aktuális állapotának. Így e törvény inkább hüvelykujjszabálynak tekinthető, semmint a gazdaság strukturális jellemzőjének. Az Okuntörvényt alapul véve Máté (2010, 1117. o.) az EU-15-re és 23 OECD-tagállamra 1960-2009 közötti adatokon végzett vizsgálatában arra az eredményre jutott, hogy a kibocsátási szintek közötti egységnyi változás egyre kisebb csökkenést okozott mind a munkanélküliségi, mind a foglalkoztatási ráták eltéréseiben.

Ez nem véletlen, hiszen mind szélesebb körben terjed el a technológiai fejlődés által megvalósítható munkahelyteremtés nélküli növekedés ${ }^{13}$ (jobless growth), amelyet elöször az Amerikai Egyesült Államokban figyeltek meg (Khemraj et al., 2006; Martus, 2015). Martus (2015) a munkahelyteremtés nélküli növekedés okait három csoportra osztotta: munkaszervezéssel összefüggő (például a just-in-time rendszerek térnyerése), strukturális (szektoriális és technológiai változások) és termelési folyamatokra (például a termelékenység növelése gépesítéssel). Ráadásul bizonyos esetekben a gazdasági növekedés nemcsak, hogy nem vezet a munkanélküliség csökkenéséhez, de növelheti azt.

Siyal et al. (2013) ${ }^{14}$ arra hívják fel a figyelmet, hogy különösen a fejlődő országokban jellemzőek azok a strukturális változások, amelyek a szegénység csökkentése érdekében bevezetett technológiai fejlesztésekkel járnak, és amelyek során a hagyományos gazdasági tevékenységekről a modern szektorokra terelődik a hangsúly. Ez növekvő munkanélküliséget idéz elő: egyrészt a termelékenység növekedése miatt, másrészt mivel a munkaerő nem szerzi meg azonnal a technológiai fejlődéssel párhuzamosan az új állások betöltéséhez szükséges szaktudást. Összességében a termelés növekedésétől elmarad a foglalkoztatási mutatók javulása. Zagler (2009) azt állapítja meg, hogy a gazdasági növekedést előidéző strukturális változások a fejlett országokban szintén a munkanélküliség átmeneti emelkedéséhez vezetnek, a munkanélküliség az új, hosszú távon érvényesülő egyensúlyi szintjénél is magasabb lesz. Ez úgy történhet meg, hogy a munkavállalók a szolgáltató szektorban megjelenő újabb vállalatokhoz való belépés reményében kilépnek a korábbi munkahelyükről, azonban (például az alkalmazás költségei miatt) nem találnak azonnal új állást. Hori (2008) a kompetitív egyensúlyi üzleti modellekből (competitive-equilibrium business cycle models) indul ki,

${ }^{13}$ A munkahelyteremtés nélküli gazdasági növekedés témaköréről lásd részletesen például Martus (2015).

14 Siyal et al. (2013) öt dél-ázsiai ország (Banglades, Bhután, India, Pakisztán és Sri Lanka) esetében vizsgálták a gazdasági növekedés a munkanélküliség kapcsolatát 1990-2010 között. A szerzők arra jutottak, hogy az ezekben az országokban a globalizáció és a makrogazdasági reformok következtében jelentkező strukturális változások valóban a munkanélküliség emelkedésével jártak, ezért szükségesnek tartják az intézményi környezet fejlesztését, valamint a pénzügyi és társadalmi reformok bevezetését. 
amelyek szerint a termelékenységi sokkok növelik a munkakeresletet, így növelik a foglalkoztatást. Azonban mivel az empirikus tapasztalatok nem támasztják alá ezt a feltevést, a szerző arra a következtetésre jut, hogy a tartós pozitív sokkok növelik a foglalkoztatás szintjét, ellenben az átmeneti pozitív sokkok csökkentik azt.

A technológiai fejlődés és a termelékenységjavulás átalakult ${ }^{15}$ szerepével kapcsolatban fontosnak tartjuk megjegyezni, hogy az önmagában nem lenne törvényszerüen a foglalkoztatást csökkentő tényező. Egy vállalat foglalkoztatottainak számáról annak vezetője dönt, és e döntés hátterében a legmélyebben a profitmaximalizálás célja húzódik. A napjainkra oly jellemző kiélezett piaci versenyben a profit növelésének fő eszköze a költségcsökkentés. A termelési költségek csökkentésének egyik módja (például a bércsökkentés mellett) pedig a foglalkoztatás-csökkentés, és ezt azonos (vagy akár növekvő) kibocsátás mellett a technológiai fejlesztések teszik lehetővé. Így közvetve valóban növekedhet a munkanélküliség a technológiai fejlődés révén, de ennek a fő oka valójában a profitkényszer. (Ahol a továbbiakban szóba kerül a technológiai fejlődés hatása, ezt az összefüggést mindig odaértjük.) Ennek ellensúlyozására napjainkban a környezeti és társadalmi fenntarthatóság érdekében egyre inkább elterjed a felelősségteljes kutatás és innováció ${ }^{16}$ elve, például az Európai Unióban is egyfajta szakmapolitikai irányelvként jelenik meg (Buzás-Lukovics, 2015)

A legutóbbi gazdasági válságok és sokkok nyomán már inkább a munkahelyteremtés nélküli fellendülésről (jobless recovery) beszélünk, ami az Amerikai Egyesült Államokban, Európában és a fejlődő országokban egyaránt megfigyelhető (Martus-Urbánné Mező, 2016). Ez tulajdonképpen azt jelenti, hogy a növekedést (a termékpiacot) kevésbé veti vissza egy válság és az azt követő időszak, mint a munkaerőpiacot. Ebben az esetben is a strukturális munkanélküliség jelenik meg, vagyis az álláskeresők képesítése és az álláshelyek illeszkedésének hibája napjainkban olyan méreteket ölt, hogy jelentősen megnöveli a hosszú távú munkanélküliséget.

Mindez azt támasztja alá, hogy a gazdasági növekedés önmagában nem eredményezi a foglalkoztatás javulását, mivel egyre lazábbá válik a kapcsolat a bruttó hazai termék és a munkanélküliségi ráták alakulása között, különösen, ha a pozitív gazdasági növekedés munkanélküliség-csökkentő hatását vesszük. Éppen ezért a kibocsátás fellendítését célzó gazdaságpolitikákkal ma már nem javíthatók olyan mértékben a munkapiaci mutatók,

\footnotetext{
${ }^{15}$ Ahogyan már korábban ismertettük, az 1980-as években elterjedt reál üzleti ciklusok elmélete épp ennek ellenkezőjét állította, vagyis, hogy a munkanélküliség a technológiai fejlődés hiányában lép fel.

${ }^{16}$ A felelősségteljes kutatás és innováció ,,legfontosabb elemei a társadalomközpontúság, az értékalapú elfogadás, a társadalmi kívánatosság, a fenntarthatóság, az etikusság, a jövőorientáltság, a versenyképesség, az érdekeltek bevonása, az átláthatóság, az interaktivitás és a multidiszciplinaritás” (Buzás-Lukovics, $2015,448$. o.)
} 
mint korábban, ezért sokkal nagyobb jelentőséget kapnak a célzott munkaerőpiaci politikai lépések. ${ }^{17}$ Emellett természetesen nagy jelentősége van a globális környezetnek is, hiszen az elmúlt szűk három évtized alatt olyan változások következtek be a nemzetközi áramlásokban (információ, áru, tőke, munkaerő), amelyek szintén befolyásolják a munkanélküliség alakulását, és amelyek további megfontolásokat tesznek szükségessé a probléma kezelése során.

\subsection{A GLOBALIZÁCIÓ HATÁSA A MUNKANÉLKÜLISÉGRE}

A globalizáció ${ }^{18}$ napjainkban minden gazdasági folyamatot befolyásol, így értelemszerủen kihat a munkanélküliségre is. Ez a hatás meglehetősen összetett. A bővülő exportlehetőség növelheti a foglalkoztatottságot egy országban, azonban a termelés alacsonyabb munkaköltségü országokba történő kiszervezése (outsourcing) a fejlett országokban jelentős strukturális munkanélküliséghez vezet. De még a tőkekiáramlás lehetősége sem csak negatívan befolyásolhatja a foglalkoztatási ráta nagyságát, hiszen ez a fenyegetés arra ösztönözheti a szakszervezeteket, hogy a béralkuk során visszafogottabb követelésekkel éljenek (HarmsHefeker, 2003). Másrészt a globalizáció következtében a feltörekvő gazdaságok termékei nemzetközi szinten is egyre inkább versenyképesek lettek/lesznek, ami növeli a versenyt és fenntartja az innovációs kényszert a fejlettebb országok vállalatai számára - ennek következtében pedig a fennmaradó vállalatok termelékenysége és jobbára még a foglalkoztatása is emelkedik (Mouhammed, 2011). Ebben az alfejezetben kissé bővebben megvizsgáljuk a munkanélküliség kapcsolatát a globalizációval és annak három alapvető elemével: a nemzetközi kereskedelemmel, a külföldi működőtőke beruházásokkal (FDI) és a nemzetközi migrációval (Falusné Szikra, 1999). Tekintettel arra, hogy az elmúlt évtizedekben jelentős változások következtek be a gazdasági folyamatok természetében, csak az elmúlt néhány év tanulmányait vesszük alapul.

Az új információs technológia elterjedésének egyik alapvető következménye, hogy csökken a képzetlen munkaerő iránti kereslet. Emellett világszerte megfigyelhető jelenség, hogy a hagyományos szakmák elavulnak, és sokszor teljesen el is tünnek - emiatt pedig szükségessé válik a szakmaközi mobilitás, az akár többszöri szakmaváltoztatás a munkaképes kor során. Ehhez pedig sok esetben nem tud elég gyorsan alkalmazkodni az oktatási és képzési

\footnotetext{
${ }^{17}$ Ezekkel a 2.5. alfejezetben foglalkozunk bővebben.

${ }^{18}$ A globalizáció sokféleképpen definiált fogalom, jelen esetben értelmezzük a „,nemzeti gazdaságok összekapcsolódásának és kölcsönös függösége elmélyülésének folyamataként, amelyik a gazdasági áramlások liberalizálásával párosul" (Simai 2008, 47. o.).
} 
rendszer. Mindezek alapján Wilpert (2009) szerint a munkanélküliség fő oka nem a gazdasági ciklusok hullámzása, hanem a globális verseny és a termelékenység drasztikus növekedése.

Felbermayr et al. (2011) eredményei árnyalják ezt a képet a hosszú és rövid távú hatások elkülönítésével. A szerzők a kereskedelmi nyitottság rövid távú hatásaként a frikcionális munkanélküliség növekedését azonosítják, amely a szektorközi mobilitás következményeként jelenik meg. Azonban hosszú távon már összetettebbnek ítélik a nemzetközi kereskedelemben való aktív részvétel foglalkoztatásra gyakorolt hatásait, amit az is alátámaszt, hogy az elméleti szakirodalom eltérő eredményeket mutat fel a kérdésben. Felbermayr et al. (2011) empirikus adatokra támaszkodva ${ }^{19}$ azt a következtetést vonják le, hogy hosszú távon a munkanélküliség strukturális rátája a kereskedelmi nyitottságnak nem növekvő függvénye: a legtöbb esetben a nyitottság csökkenti a munkanélküliséget, a fennmaradókban pedig nem befolyásolja. Az aggregált munkanélküliség csökkenése elsősorban annak köszönhető, hogy a magasan képzett munkavállalók körében csökken a munkanélküliség. Dutt et al. (2009) panelvizsgálatuk során gyakorlatilag ugyanerre az eredményre jutottak: a kereskedelmi liberalizáció rövid távon növeli a munkanélküliséget, hosszú távon azonban csökkenti, ami egy új egyensúlyi állapotot eredményez - és ebben lényegében nem játszik szerepet az, hogy tőkében vagy munkában gazdag országot veszünk-e alapul.

A nemzetközi kereskedelem munkanélküliségre gyakorolt hatása alapján tehát alapvetően nem káros egyik fél számára sem. A tőkeáramlás esetében azonban egy sokkal inkább aszimmetrikus helyzet rajzolódik ki. A technológiai fejlődés következtében csökkentek a tőkejavak kereskedelmének korlátai, ami a nemzetközi kereskedelemben résztvevő országok bérszínvonalára és foglalkoztatására is hatással van. A müködőtőke kiáramlásának elméletben kétféle következménye lehet az adott ország számára: a hazai termelés csökkenése miatt az aggregált egyensúlyi munkanélküliség megnövekszik, vagy éppen fordítva, a növekvő világpiaci részesedés következtében állandósul vagy nő a foglalkoztatás. A kiáramló portfólióberuházások hatását illetően is hasonlóképpen megoszlanak a vélemények. Lin és Wang (2004) panelvizsgálata arra mutat rá, hogy a fejlődő országokban a kiáramló FDI növeli a hazai foglalkoztatást, míg a kiáramló portfólió-beruházás csökkenti azt. Ezzel szemben a fejlett (iparosodott) országokban nem figyeltek meg ilyen egyértelmü kapcsolatot a változók között. Eckel (2003) a hatékony béreket egy neoklasszikus kereskedelmi modellbe bevezetve jut arra

${ }^{19}$ Felbermayr et al. (2011) panel regresszió és keresztmetszeti elemzési módszert alkalmazva 20 OECD országot, majd egy nagyobb, 62 országból álló mintát alapul véve vonják le következtetéseiket. A kereskedelmi nyitottság mérésére a reál kereskedelmi nyitottság mutatóját használják, amely az import és export USD-ban kifejezett összegének és a vásárlóerő-paritáson mért, USD-ban kifejezett GDP-nek a hányadosaként adódik. A munkanélküliség mérésére több forrásból származó mutatókat használnak. A vizsgálat során kiemelt figyelmet fordítanak az üzleti ciklusok ingadozásainak kiegyenlítésére. 
az eredményre, hogy a relatív bérek és a munkanélküliség alakulása független a bérmerevségektől, az igazi jelentősége a tőkeáramlás irányának van. A tőkeexportáló országok emelkedő munkanélküliségre számíthatnak, míg a tőkeimportáló országokban a munkanélküliség alakulása nem ilyen egyértelmű, viszont a magasabb képzettséget igénylő munkák bérei (skill premium) emelkednek. Schmerer (2014) 19 OECD ország vizsgálatára alapozva pedig azt a következtetést vonja le, hogy a munkanélküliség alakulása szempontjából a nettó FDI (vagyis a be- és kiáramló FDI különbsége) a meghatározó: míg a fogadó országban a megfelelő iparágban nő a termelés és csökken a munkanélküliség, a nettó működőtőkeexportőr országokban növekszik az egyensúlyi munkanélküliség.

Lehetséges azonban a tőkeexportőr országokban jelentkező foglalkoztatás-csökkenést ellensúlyozni. Harms és Hefeker (2003) modellje azon alapul, hogy a globalizáció miatt a munkavállalók nem kizárólag bérjövedelemre tehetnek szert, hanem a megtakarításaik külföldi befektetése révén is jövedelemhez juthatnak. Amennyiben e befektetések megtérülései a (belföldi) munkakeresleti sokkokkal negatívan korrelálnak, úgy a hazai szakszervezetek alacsonyabb bérköveteléssel is megelégszenek. Ez pedig magasabb foglalkoztatottságot tesz lehetővé. A két szerző ezzel arra mutat rá, hogy a munkanélküliség visszaszorítása szempontjából előnyös lehet a tőkejövedelmek diverzifikációját ösztönző politika, vagyis a fejlett országok munkavállalóinak ebből a szempontból is érdemes lehet élni a felemelkedő gazdaságokba irányuló befektetési lehetőségekkel.

A globalizáció következtében fellépő nagymértékű nemzetközi migráció munkanélküliségre gyakorolt hatása függ a munkapiaci intézményektől, a munkaerőpiaci politikáktól (Lipsmeyer-Zhu, 2011). Ha egy országban magas a munkanélküliség, akkor az növeli a migrációs/elvándorlási hajlandóságot. Az úgynevezett agyelszívás (brain drain, a képzett munkaerő elvándorlása a fejlődőkből a fejlett országokba) miatt megfigyelhetővé vált a fejlődő országokban az oktatásban való részvétel növekedése, hiszen a humán tőke minőségének javítása hozzásegíti a munkavállalókat a számukra kedvezőbb feltételeket biztosító külföldi (fejlett országokban elérhető) állások megszerzéséhez. Ez pedig érdekes módon azt eredményezi, hogy a fejlődő országokban az agyelszívás mégsem vezet a képzett munkaerő hiányához: a brain drain helyett brain gain jelentkezik, sőt, a munkakínálat növekedése révén inkább a képzett munkaerő körében jelentkező munkanélküliséget eredményez (Eggert et al., 2010; Fan-Stark, 2007; Vargas-Silva, 2011). Hasonlóképp a hazautalások szerepe sem egyértelmü: bár a fejlődő országban maradt család számára rendkívül fontos az elvándorolt családtag által hazaküldött jövedelem, sok esetben ez ahhoz vezet, hogy a hazautalásban részesülő háztartások munkaerőpiaci részvétele csökken (Vargas-Silva, 2011). 
A bevándorlás hatása a munkaerőpiacra ugyancsak nem egyoldalú: a bevándorlók és a hazai munkavállalók képzettségétől és készségeitől (hogy helyettesítik vagy kiegészítik-e egymást), valamint a fogadó gazdaság jellemzőitől függ. Ráadásul a bevándorlás nem csak a munkakínálatot, de a munkakeresletet is növel(het)i, hiszen a bevándorlók is igényelnek különféle szolgáltatásokat, termékeket (Ruhs-Vargas-Silva, 2015).

A globalizáció munkapiaci intézményekre gyakorolt hatásáról eltérő empirikus eredmények születnek az intézményi háttér sokrétüsége miatt - különösen a fejlett országokban (Potrafke, 2013). Gyakran hangoztatott nézet, hogy a globalizáció következtében a képzetlen munkaerő egyre romló munkakörülményekkel és növekvő munkanélküliséggel kénytelen szembesülni. Ennek oka a nemzetközi verseny kiéleződése, aminek következtében a cégek igyekeznek növelni a hatékonyságukat, a kormányok pedig csökkentik a munkaerőpiaci szabályozás mértékét, hogy vonzóbb célponttá váljanak a külföldi tőke számára. Mindez kihat a bérek és a foglalkoztatás nagyságára egyaránt. Potrafke (2013) 140 országot felölelő panelvizsgálata azonban arra az eredményre vezetett, hogy a globalizáció nem eredményez munkapiaci deregulációt. Példaként említi a Skandináv országokat és a kontinentális Európa egyes országait, ahol az erőteljesen megjelenő globalizációs hatások nem ásták alá a munkapiaci intézményeket. Emellett azt is megállapítja, hogy egyes kormányok a globalizáció negatív következményeinek (a növekvő külső kockázatok) ellensúlyozása érdekében tovább erősíthetik a munkapiac szabályozottságát és növelhetik a szociális kiadásaikat, a versenyképességük megtartását illetve növelését pedig a tőkepiacok liberalizálásával érik el. Hellier és Chusseau (2010) szerint a globalizáció egy további eredménye a fejlett (északi) országok számára, hogy egyfajta kényszerhelyzetet generál, amelyben választaniuk kell a jövedelemegyenlőtlenség és a munkanélküliség között. Ez annál erősebben jelenik meg, minél inkább jellemzőek voltak korábban az adott országra a jövedelemegyenlőtlenségek. Azok az (európai) országok, amelyek korábban (az 1990-es évek elejéig) nem törekedtek az egyenlőtlenségek visszaszorítására, de szeretnék elkerülni azok további növekedését, két lehetőség közül választhatnak: vagy elfogadják a magas munkanélküliséget a képzetlen (és alacsonyan képzett) munkaerő körében, vagy lépéseket tesznek a szakképzett munkaerő gyors növelése érdekében. A korábban egalitárius politikát folytató országoknak azonban jobb lehetőségeik vannak az egyenlőség fenntartására a munkanélküliség növekedése nélkül is. Eszerint, hogy az egyenlötlenséget vagy a munkanélküliséget engedje-e növekedni egy ország, az tulajdonképpen a saját választásán múlik.

Mindezek az alpján az mondható el, hogy a globalizáció hatása a munkaerőpiacra nem egyértelmü, nagyban függ a globális folyamatokra adott nemzeti gazdaságpolitikai válaszoktól. 


\section{5. ÁLLAMI ESZKÖZÖK A MUNKANÉLKÜLISÉG CSÖKKENTÉSÉRE}

A munkanélküliség okainak azonosítása után ebben az alfejezetben röviden ismertetjük a foglalkoztatás növelését elősegítő gazdaságpolitikai lehetőségeket. A dolgozat későbbi fejezeteiben a fiatal korosztályt érintően részletesebben is bemutatjuk a munkanélküliség csökkentését célzó gazdaság- és foglalkoztatáspolitikai eszközöket, azonban szükségesnek tartjuk, hogy itt is kitérjünk az általánosan elfogadott lehetőségek ismertetésére.

A munkanélküliség - főként a magas munkanélküliség - egyaránt jelent gazdasági és társadalmi problémát is. A magas munkanélküliségből következően a potenciális szinttől elmaradó termelés a modern gazdaságok egyik legnagyobb kimutatható vesztesége (Samuelson-Nordhaus, 2012, 539. o.). Érthető az is, hogy a tartós munkanélküliség a társadalmi különbségek növekedéséhez vezet, ami jelentős feszültségeket szülhet. Gondoljunk csak a 2008-as válság alatti tüntetésekre: ezek alapvetően nem az elmaradt termelés miatt alakultak ki, hanem a munkahelyek megszünése, a leépítések, és általában a mindennapi életet nehezítő megszorító intézkedések miatt. A munkanélküliségnek, különösen, ha hosszú ideig húzódik, súlyos pszichológiai következményei is vannak. Olyan központi kérdésről van tehát szó, amely alapvető jelentőséggel bír egy gazdaság és társadalom működésében, éppen ezért a modern gazdaságokban elkerülhetetlen, hogy az állam valamilyen szinten beavatkozzon a munkapiaci folyamatokba.

Az államnak nagy szerepe lehet a munkanélküliség visszaszorításában. (Ami természetszerüleg az ifjúsági munkanélküliség csökkentésével is jár.) Mouhammed (2011) a szabályozási környezeten kívül számos más tényezőt is kiemel, amelyek elősegítik a foglalkoztatás növelését, így minden olyan állami intézkedés, amely ezeket segíti, hozzájárulhat a munkanélküliség csökkentéséhez is. Ezek a kedvező gazdasági környezet és a technológiai fejlődés jellemzői (2.3. táblázat). A technológiai fejlődés tényezőinek (főként a termelékenységjavulásnak) azonban a foglalkoztatást csökkentő hatása is lehet, hiszen a munkahelyteremtés nélküli növekedést is jobbára a technológiai fejlődés teszi lehetővé. Ám ez a kedvezőtlen hatás nem érvényesül, ha a termelékenység javulását a kereslet megfelelő mértékü növekedése kíséri, vagy új munkakörök alakulnak ki általa (ami felszívja a feleslegessé vált munkaerőt), vagy a technológiai fejlődés a munkakörülmények javulását segíti. 
2.3. táblázat A munkanélküliség csökkenését segítő tényezők

\begin{tabular}{ll}
\hline Szempontok & Tényezők \\
\hline \multirow{2}{*}{ kedvező gazdasági } & - kedvezö növekedési kilátások \\
környezet & - olcsó hitellehetőségek az üzleti vállalkozások számára \\
& - nyersanyagok (különösen az olaj) árának csökkenése \\
& - hazai magán és közösségi reálberuházások növelése \\
\hline & - gazdasági és pénzügyi bizonytalanságok (szabályozás, \\
kedvező szabályozási & munkaköltségek) csökkentése \\
környezet & - versenyző piacgazdaság támogatása \\
& - adócsökkentés \\
& - munkahelyekkel kapcsolatos információk hozzáférhetősége \\
\hline \multirow{3}{*}{ technológiai fejlődés } & - technológiai fejlődés és innovációk \\
& - folyamatos termelékenységjavulás \\
& - a munkavállalók készségeinek és képességeinek javítása
\end{tabular}

Forrás: Mouhammed (2011, 108-109. o.) alapján saját szerkesztés.

A közvetlenül a foglalkoztatás javítását célzó kormányzati politikáknak, más néven a foglalkoztatáspolitikai eszközöknek két csoportja van: az aktív munkaerőpiaci politikák (Active Labour Market Policies, ALMP) és a passzív ellátások (szociális támogatások, segélyek). Az állami beavatkozások célja a munkaerőpiac hatékony müködésének támogatása és az egyensúlytalanságok kiigazítása oly módon, hogy meghatározott munkaerőpiaci csoportokat támogatnak. A passzív ellátások célja a munkanélküliség negatív következményeinek csökkentése, az állásvesztésből fakadó jövedelemcsökkenés kompenzálása. Így ezek nem növelik a foglalkoztatást, sőt, adott esetben csökkentik is a munkavállalási hajlandóságot a már ismertetett helyettesítési hatás következtében. Ide tartoznak a munkanélküli-ellátások, segélyek és a korai nyugdíjazást finanszírozó támogatások is (Scharle, 2008). Az aktív munkaerőpiaci politikák célja ellenben a munkanélküli és inaktív személyek álláshoz juttatása, valamint a veszélyeztetett foglalkoztatottak segítése munkájuk megtartásában. A munkanélküliek támogatása egyrészt a munkavégző képességük javítása, másrészt a munkakereslet ösztönzése révén valósul meg (Scharle, 2008). Az ALMP-k közé tartoznak például az állami és magán foglalkoztatási szolgálatok, a munkavállalást és vállalkozásindítást ösztönző eszközök, különféle képzések, vagy speciális segítség nyújtása a munkaerőpiacon hátrányos helyzetben lévő csoportok számára (BusinessEurope et al., 2015). A munkaerőpiaci politikai kiadásokból a következő csoportok részesülnek: (regisztrált) álláskeresők, veszélyeztetett foglalkoztatottak (akik nagy eséllyel ki vannak téve az állásvesztés kockázatának), valamint azok az inaktívak, akik szeretnének belépni a munkaeröpiacra, és valamilyen szempontból hátrányos helyzetben vannak. ${ }^{20}$ Napjainkban - ahogyan korábban is

\footnotetext{
${ }^{20}$ http://ec.europa.eu/eurostat/cache/metadata/en/lmp_esms.htm
} 
utaltunk rá - az egyik kiemelt strukturális probléma az álláskeresők képesítése és az álláshelyek betöltéséhez szükséges készségek illeszkedésének hibája. Kroft et al. (2016) ennek orvoslására három aktív munkapiaci politikai intézkedést tekint hasznosnak:

1. bérkompenzáció a magasabb fizetésű állásukat elvesztett munkavállalók számára, ami alacsonyabb bért kínáló állás elfogadására ösztönöz;

2. az álláskeresést támogató szolgáltatások, az oktatási és képzési rendszer fejlesztése;

3. ágazat-orientált képzési programok, melyek a helyi munkaadókkal szoros együttműködésben kerülnek kialakításra.

Más szempontból a munkanélküliség csökkentésére irányuló eszközök két csoportja a munkaerőpiac kínálati oldalára, valamint a keresleti oldalára ható eszközök (CDPS, 2001). A kínálati oldalon megjelenő eszközök skálájának egyik végpontja az (elméleti alapokon nyugvó) oktatási rendszer munkapiaci keresleti viszonyokhoz igazítása; ${ }^{21}$ a másik pedig a gyakorlati tudás, munkatapasztalat növelése (munkahelyi képzés, on-the-job training). A kettő között helyezhető el a gyakornoki rendszer. A keresleti oldalra ható eszközök célja az új álláshelyek létrehozása, ami történhet egyrészt a vállalkozóvá válás támogatása, másrészt a közvetlenül vagy közvetve támogatott foglalkoztatási programok révén. A fiatalok esetében a közvetlenül támogatott foglalkoztatás azt jelenti, hogy a munkáltató állami hozzájárulásban részesül, ha munkanélküli fiatalt alkalmaz; míg a közvetett támogatás csökkentett adó- és/vagy járulékfizetési kötelezettséget (bértámogatást) jelent a munkáltató számára, amennyiben munkanélküli fiatalt kezd foglalkoztatni.

A munkanélküliség csökkentésére tehát többféle célzott állami eszköz is rendelkezésre áll, amelyeket az aktuális gazdasági helyzethez és a társadalmi elvárásokhoz igazodva használnak az országok kormányai. Ezek alkalmazása és hatékonysága függ továbbá attól is, hogy maga a munkaerőpiac milyen jellemzőkkel bír. A továbbiakban a munkaerőpiacok egy meghatározó tulajdonságával, a rugalmassággal foglalkozunk, kiemelten annak a munkanélküliség alakulására gyakorolt hatásával.

21 Az oktatási rendszer minősége meghatározó a munkaerőpiacon szükséges képzettség és készségek elsajátítása szempontjából. Napjainkban az ,,alapvetö olvasási és számolási képességek mellett egyre inkább elötérbe kerülnek az olyan kompetenciák, mint a kritikus gondolkodás vagy a kommunikációs készségek, nyelvismeret stb." (Laczi et al., 2016, 88. o.) 


\section{A MUNKAERŐPIACI RUGALMASSÁG JELENTŐSÉGE}

A munkaerőpiaci rugalmasság, illetve annak mértéke meghatározó az adott országban a foglalkoztatás és munkanélküliség szempontjából, mégsem teljesen egyértelmü a szerepe. Széles körben elfogadott gondolat, hogy a rugalmas munkaeröpiac stabil makrogazdasági körülmények között versenyképesebb és magasabb termelékenységü gazdaságot eredményez, amely így a gazdasági változásokra is képes jobban reagálni (HM Treasury, 2003). Általánosságban az a vélekedés, hogy a rugalmas munkapiacok a dolgozók számára kedvezötlenek, mivel megkönnyítik a munkáltatók számára az elbocsátásokat. A rugalmasságnak azonban sokkal több vetülete van, melyek közül némelyek kedveznek a munkavállalóknak - például megkönnyítik a munkaerö felvételt a vállalatok számára.

A munkaerőpiaci rugalmasság terminust többféle megközelítésben lehet értelmezni, s ennek megfelelően nem is létezik rá egyetlen általánosan használt definíció (Pula, 2005). Van, aki a munkaerőpiac gazdasági sokkokat követő alkalmazkodásának gyorsaságát tekinti rugalmasságnak; mások szerint az a rugalmas munkaerőpiac, amelyben alacsony strukturális munkanélküliséggel járó egyensúly érvényesül; és van, aki a bérszabályozást és a munkapiaci kereslet és kínálat alakulását befolyásoló intézményi tényezőkben látja a rugalmasság lényegét (HM Treasury, 2003; Reed, 2010). Egyik megközelítés sem jobb vagy rosszabb a másiknál, mégis fontos, hogy ugyanazt értsük a fogalom alatt, amikor erről beszélünk, ezért a továbbiakban ismertetjük a munkapiaci rugalmasság általunk használt definícióját.

\subsection{A MUNKAPIACI RUGALMASSÁG ELMÉLETI MEGKÖZELÍTÉSE}

Az újklasszikus közgazdaságtan elméleti keretében a rugalmasság a hosszú távú egyensúlyi trendhez való visszatérés sebességét jelenti. Pula (2005) erre a ciklikus rugalmasság kifejezést használja. Ilyenkor a külső sokkokhoz való alkalmazkodás rövid távon a nominális béreken (bérrugalmasság) vagy a foglalkoztatáson (létszámrugalmasság) keresztül történhet, hosszú távon viszont a strukturális munkanélküliséghez való visszatérést a bérek változása biztosítja. Pula $(2005,15$. o.) emellett kiemeli, hogy „,minél hosszabb ideig tart az egyensúlyi pályához való visszatérés, annál nagyobb az egyensúlyi pálya megváltozásának a valószinüsége”. Ilyenkor ,„a nominális sokkoknak [...] a hosszú távú egyensúlyi trendre is hatásuk lesz, és a rugalmasság már nem az alkalmazkodás sebességeként, hanem az egyensúlyi trend megváltozásaként lesz értelmezhetö. [...] Ez az ún. strukturális rugalmasság definíciója, amely annál rugalmasabbnak tekinti a munkapiacot, minél alacsonyabb a strukturális 
munkanélküliség szintje, azaz minél kisebb a reálgazdasági áldozat mértéke” (Pula, 2005, 11. о.).

A dolgozatban az OECD meghatározását vesszük alapul. Eszerint a munkaerőpiaci rugalmasságot úgy értelmezzük, mint ,a különböző politikák kiigazitásának lehetősége a tervezéstöl a megvalósitásig, hogy azok jobban alkalmazkodjanak a helyi körülményekhez, az egyéb szervezetek intézkedéseihez, a kitüzött stratégiákhoz, valamint a fennálló kihívásokhoz és lehetőségekhez" (Giguère-Froy, 2009a, 13-14. o.). Ebben a megközelítésben a rugalmasság alapvetően a foglalkoztatáspolitikán múlik, emellett adminisztrációs vetülete is van, és jogi, költségvetési, valamint teljesítmény-menedzsmenttel kapcsolatos elemekben egyaránt megnyilvánul (Giguère-Froy, 2009a; Mploy, 2011). Ahogyan a definíció is utal rá, a munkapiacok rugalmas müködésében kiemelt jelentősége van a lokális szintnek, ezért fontos, hogy a foglalkoztatáspolitikát meghatározó (központi vagy regionális) kormányzat kellő mozgásteret biztosítson a helyi nehézségeket és lehetőségeket ismerő hivatalnokoknak (Giguère-Froy, 2009b). Az OECD a lokális munkaerőpiacok rugalmasságát alapvetően abban látja, hogy a helyi szervezeteknek milyen szabadságuk van az aktív munkaerőpiaci politikai eszközök és programok tervezésében, megvalósításában és finanszírozásában; a célcsoportok megválasztásában; a helyi stratégiai célok kitüzésében; a stratégiai partnerek kiválasztásában; valamint egyes feladatok kiszervezésében (Mploy, 2011).

A fenti meghatározás azonban adós marad a munkaerőpiaci rugalmasság gyakorlati megközelítésével, vagyis nem adja meg azokat a szempontokat, amelyek alapján egy munkapiac rugalmasnak vagy rugalmatlannak tekinthető. A munkapiaci flexibilitásnak eltérő tipizálásai léteznek a szakirodalomban, amelyek rövid összefoglalását adja Finna (2008, 62-66. o.). Ez alapján megállapítható, hogy a különböző nézőpontokból megalkotott rugalmasságtípusok megközelítőleg ugyanazokat az elemeket fedik le, csak más csoportosításban. Klau és Mittelstadt (1986, 10-14. o.) például a munkaerőpiaci rugalmasság négy fö aspektusát nevezik meg:

1. munkaerőköltségek rugalmassága összgazdasági szinten: a termelékenység és a cserearányok változásához való alkalmazkodási képességet jelöli, legyen szó ciklikus ingadozásokról vagy külső sokkokról;

2. relatív munkaerőköltségek foglalkozások és vállalatok közötti alkalmazkodóképessége: a bérkülönbségeket meghatározó két dimenzió a munkakínálat és munkakereslet kapcsolata (a készségek/képzettség és szakmák szükössége vagy éppen túlkínálata), valamint az egyes vállalatok jövedelemtermelő ereje; 
3. munkaerő mobilitása: adott munkaerő tekintetében jelenthet földrajzi, foglalkozási és vállalatok közötti mobilitást; emellett ide értendők a munkaképes korú lakosság gazdaságilag aktív és inaktív csoportok közötti mozgásai;

4. munkaidő és munkarend rugalmassága: lényege, hogy a részmunkaidős állások létrehozása, az állásmegosztás és az állásfelosztás ${ }^{22}$ egyéb költségek generálása nélkül valósuljanak meg - ezek a foglalkoztatási formák tipikusan a női munkavállalókat érintik.

Ehhez a megközelítéshez nagyon hasonló Soltwedel et al. (1999) elgondolása is. A szerzők szerint három meghatározó tényezője van a munkapiaci külső sokkokhoz való alkalmazkodóképességének, amely befolyásolja a munkaeröpiaci teljesítményt:

1. bérrugalmasság: a munkaerő-kereslet bérrugalmasságának három eleme a béralku rendszer, a minimálbér és a nem bérjellegü munkaerőköltségek;

2. munkaidő rugalmassága: a munkaidő szabályozása és a részmunkaidős állások határozzák meg;

3. földrajzi és foglalkozások közötti mobilitás: az alkalmazás és elbocsátás költségei mellett idetartoznak a mobilitást ösztönző politikák, valamint az oktatási és képzési rendszerek.

Reed (2010, 26-29. o.) valamelyest más megközelítésben a munkaerőpiaci rugalmasság 22 összetevőjét azonosítja, s ez alapján négy nagyobb faktorba sorolja a rugalmasság szintjét meghatározó tényezőket:

1. bérrugalmasság: ezt a béralku rendszer, a minimálbér, a nem bérjellegü munkaköltségek és más, a bérekhez kapcsolódó politikák határozzák meg;

2. a munkavállalás rugalmassága: azt jelenti, hogy a munkavállalók milyen mértékben dönthetnek szabadon arról, hogy mennyi órát dolgoznak, illetve dolgoznak-e egyáltalán;

3. menedzsment rugalmasság: a munkavállalás rugalmasságát egészíti ki, és a munkáltatók szabadságát fejezi ki minden, az alkalmazottaikkal kapcsolatos döntésben;

22 Az állásfelosztás kifejezés eredetije az angol ,job-splitting”, amelynek lényege, hogy egy teljes munkaidőt és a vele járó feladatokat több részre osztanak fel több munkavállaló között, akik így egymástól függetlenül tudnak dolgozni, részmunkaidőben. Gyakran nehéz elválasztani tőle, de nem azonos az állásmegosztással (job sharing), ahol a részmunkaidőben foglalkoztatott munkavállalók adott feladatot közösen, vagy legalábbis egymással összehangoltan oldanak meg és ennek megfelelően a felelősségen is osztoznak (AllanDaniels, 1999). 
4. kompozicionális (összetételi) rugalmasság: a foglalkoztatottak (lakóhely, iparág, képzettség, készség, nemzetiség szerinti) összetételének alakítására vonatkozó szabadság.

Rodgers $(2007,2$ o. o) megint csak más nézőpontból a munkaerőpiaci rugalmasság négy dimenzióját nevezi meg, bár észre lehet venni egy-két átfedést az előzőekkel:

1. foglalkoztatottak védelme: az alkalmazás és elbocsátás szabályozása;

2. bérrugalmasság: a bérek változásait korlátozó intézmények és szabályok, mint a minimálbér, a szakszervezetek aktivitása, vagy a koordinált béralku mértéke;

3. belső vagy funkcionális rugalmasság: a vállalatok képessége a termelési és munkaerö-felhasználási folyamatok (át)szervezésére a hatékonyság növelése érdekében, például a munkaidő, a munka tartalma, a szükséges képességek és a technikai változások rugalmassága;

4. kínálati oldali rugalmasság: a munkavállalók is gyakran keresnek rugalmas munkaidejü állásokat, emellett a különböző jogosultságok munkahelyek közötti hordozhatóságára is van igény.

Keller és Seifert $(2005,307-308$. o.) a rugalmasságot két nagyobb kategóriára osztva csoportosítják:

1. belső rugalmasság: a vállalaton belül értelmezendő, leginkább a munkaidő változtatásában nyilvánul meg, a dolgozói létszámot változatlanul hagyva

a. belső számbeli (numerikus) rugalmasság: a munkaidő rugalmas kihasználását jelenti a munkahelyek megtartásának érdekében, például rugalmas munkaszervezés, túlóra, munkaidő-csökkentés, és munkaidőszámlák alkalmazásával;

b. belső funkcionális rugalmasság: a változó output igényekhez való alkalmazkodás fö eszközeként a munkafolyamatok átszervezése jelenik meg, az ennek megfelelően többféle készséggel rendelkező (multi-skilled) munkaerőre támaszkodva - ahol ez lehetséges, belső képzésekkel;

c. bérrugalmasság: a kollektív alku során kialakult bérektől való eltérés lehetőségét jelenti, például a túlóra után fizetendő bér csökkentését, a különleges juttatások eltörlését, az órabér átmeneti csökkentését; de egyre elterjedtebb a teljesítményalapú bérezés is;

d. időbeli rugalmasság: a kifejezetten a részmunkaidős munka, valamint ezen belül a jelentéktelen és marginális (alacsony díjazással és elégtelen szociális védelemmel 
járó) részmunkaidős munka alkalmazását jelentő kategória a bérrugalmassággal is kapcsolatban van;

2. a külső rugalmasság az alkalmazotti létszám változtatásának lehetőségét teremti meg a következő módokon:

a. külső számbeli (numerikus) rugalmasság: az alkalmazás és elbocsátás mellett a munkaerő-kölcsönzés és a határozott idejű szerződések tartoznak ide;

b. külső funkcionális rugalmasság: a munkaerő képességeinek és készségeinek fejlesztése a munkapiac igényeihez igazodva különféle képzésekkel a megfelelő illeszkedés érdekében;

c. külső bérrugalmasság: a munkaerőköltségek változtatása, például bérköltség támogatás alkalmazásával.

Pula (2005, 12-13. o.) - hasonlóan Pissarides (1997)-hez - az optimális valutaövezetelmélet talaján állva a munkapiac rugalmasságának három, egymással átfedésben lévő vetületét határozza meg:

1. nominálbérek rugalmassága: a bérek változtatásának lehetőségét meghatározó tényezők, vagyis a bérszerződések gyakorisága, a bérmegállapodások centralizáltsága, a szakszervezetek ereje és a minimálbérek nagysága;

2. munkakínálat rugalmassága: a munkanélküliek munkapiaci kötődését jelenti, vagyis azt, hogy a munkanélküliek milyen mértékben képesek versenyezni a foglalkoztatottakkal az álláshelyekért - ezt pedig döntően a munkakeresés intenzitása (amely függhet például a munkanélküli segélyek nagyságától vagy a földrajzi mobilitástól) és az álláskereső képzettsége és képességei határozzák meg;

3. munkakereslet rugalmassága: a vállalat képességét a bér, létszám és a munkaerő összetételének alakítására befolyásolják az alkalmazás és elbocsátás költségei, a munkajogi szabályok és a munkaerőköltséget növelő adók.

E megközelítések közül Pula (2005) cikkéhez kapcsolódik a 3.1. ábra, de valójában a többi kiemelt tipizálás alapján is az szürhető le, hogy a munkapiaci rugalmasság általában véve a munkaerőköltségekkel, a munkaidővel és a munkaerő mobilitásával jellemezhető. 
3.1. ábra A munkaerőpiaci rugalmasság jellemzői

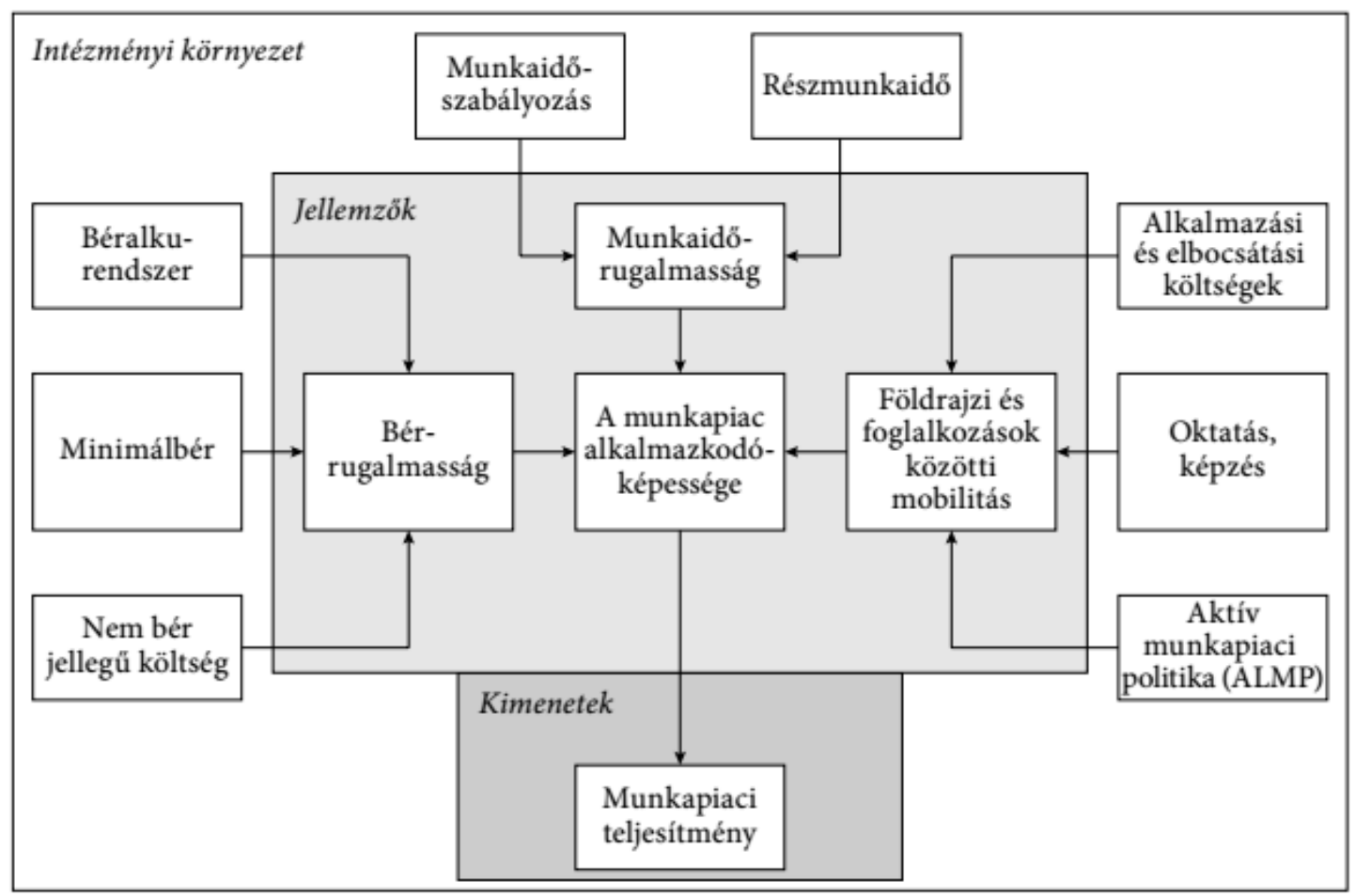

Forrás: HM Treasury (2003), Soltwedel et al. (1999), Urbánné Mező-Udvari (2016, 435. o.)

Mindezek alapján látható, hogy rendkívül összetett kérdésről van szó, nem könnyü feladat objektíven meghatározni, hogy egy adott országban vagy térségben mennyire rugalmas a munkaerőpiac. Ennek ellenére természetesen léteznek különböző indikátorok, amelyek lehetővé teszik az egyes államok összehasonlítását. A továbbiakban ezeket vesszük sorra.

\subsection{A RUGALMASSÁG MÉRÉSÉNEK LEHETÖSÉGEI}

Mivel a munkaerőpiaci rugalmasságnak több különböző vetülete van, nem lehet azt egyetlen mutatóval összefoglalni, ezért a mérésére több indikátor együttesen használatos (3.1. táblázat). Ilyen indikátorokat közzétesz például az OECD adatbázisa, a World Economic Forum (WEF), az International Institute for Management Development (IMD), és a Fraser Institute is. ${ }^{23}$ Ezek a mutatók nagyobbrészt lefedik a 3.1. ábrán összefoglalt rugalmassági jellemzőket. Aleksynska és Cazes (2014) kritikai áttekintést ad az utóbbi három szervezet által kidolgozott mutatókról, amelyben felhívja a figyelmet azok hiányosságaira, amelyek miatt elméleti és módszertani problémákat egyaránt felvet a használatuk. A legnagyobb problémát abban látják, hogy mind a három szervezet az Employing Workers Index (EWI) nevü mutatót használja - a Világbank

23 A WEF a globális versenyképességi rangsoraiban (Global Competitiveness Index), az IMD a versenyképességi évkönyveiben (World Competitiveness Yearbook), a Fraser Intézet pedig az országok gazdasági értelemben vett szabadságát reprezentáló rangsorában (Economic Freedom of the World Index) összesíti a munkapiaci szabályozásra és rugalmasságra vonatkozó adatokat (Aleksynska-Cazes, 2014). 
üzleti környezet minőségét jellemző (Ease of Doing Business) indikátorának egyik korábbi alindikátorát. Ez a mutató pedig csak a foglalkoztatás szabályozásának rugalmasságáról ad képet, azonban más dimenziókról, mint például a munkaerő védelméről már nem. Lényegében a szabályozás költségeire koncentrál, az előnyeit viszont figyelmen kívül hagyja. Éppen ezért - bár az elmúlt években jelentősen fejlesztették - maga a Világbank sem ajánlja e mutató használatát ország rangsorok kialakítására és foglalkoztatáspolitikai döntések megalapozására.

\section{1. táblázat A munkaerőpiaci rugalmassághoz kapcsolódó mutatók}

\begin{tabular}{|c|c|c|}
\hline $\begin{array}{l}\text { Rugalmasság } \\
\text { dimenziója }\end{array}$ & Mutató neve & A mutató tartalma, kapcsolata a rugalmassággal \\
\hline \multirow{3}{*}{$\begin{array}{l}\text { Bér- } \\
\text { rugalmasság }\end{array}$} & $\begin{array}{l}\text { Reál minimálbér (medián- vagy) } \\
\text { átlagkeresethez viszonyított aránya }\end{array}$ & $\begin{array}{l}\text { Minél magasabb a minimálbér, annál kevésbé } \\
\text { tekinthető rugalmasnak a munkaerőpiac. }\end{array}$ \\
\hline & Adóék & $\begin{array}{l}\text { Minél nagyobb az adók és járulékok aránya a } \\
\text { munkáltató által fizetett teljes munkaerőköltségen belül, } \\
\text { annál kevésbé rugalmas a munkapiac. }\end{array}$ \\
\hline & $\begin{array}{l}\text { Szakszervezeti szervezettség szintje } \\
\text { (Trade Union Density) }\end{array}$ & $\begin{array}{l}\text { Minél nagyobb a szakszervezeti tagsággal rendelkező } \\
\text { foglalkoztatottak összes foglalkoztatotthoz viszonyított } \\
\text { aránya, annál rugalmatlanabb a munkaerőpiac, mivel a } \\
\text { szakszervezetek tevékenysége nyomán emelkednek a } \\
\text { bérek. }\end{array}$ \\
\hline \multirow{5}{*}{$\begin{array}{l}\text { Munkaidő } \\
\text { rugalmassága }\end{array}$} & $\begin{array}{l}\text { Részmunkaidős foglalkoztatottak } \\
\text { aránya a teljes foglalkoztatáson } \\
\text { belül }\end{array}$ & $\begin{array}{l}\text { A részmunkaidős foglalkoztatás atipikus foglalkoztatási } \\
\text { forma, ezek pedig a rugalmas munkaerőpiacokon } \\
\text { jellemzőek, ezért e mutató magasabb értéke } \\
\text { rugalmasabb munkapiacot jelöl. }\end{array}$ \\
\hline & $\begin{array}{l}\text { Nem önkéntesen részmunkaidőben } \\
\text { dolgozók aránya a részmunkaidős } \\
\text { foglalkoztatottakon belül }\end{array}$ & $\begin{array}{l}\text { Ezek a munkavállalók inkább teljes munkaidőben } \\
\text { dolgoznának, ha volna rá lehetőségük, de még így is } \\
\text { kedvezőbb helyzetben vannak a másik lehetőségükhöz, } \\
\text { a munkanélküliséghez képest. Ugyan a mutató tartalma } \\
\text { negatív, mégis a rugalmasabb munkapiac jellemzöjének } \\
\text { tekinthetö, különösen, ha a rugalmasságot a } \\
\text { munkakeresleti oldalon megjelenő lehetőségekben } \\
\text { (Rodgers-féle belső vagy funkcionális rugalmasság) } \\
\text { értjük. }\end{array}$ \\
\hline & $\begin{array}{l}\text { Átlagos heti munkaórák száma a } \\
\text { fóállásban }\end{array}$ & $\begin{array}{l}\text { A mutató magasabb értéke merevebb munkapiacot } \\
\text { takar (például nehezebb másodállást vállalni). }\end{array}$ \\
\hline & $\begin{array}{l}\text { Határozott idejü (ideiglenes) } \\
\text { munkaszerződéssel dolgozók összes } \\
\text { foglalkoztatotton belüli aránya }\end{array}$ & $\begin{array}{l}\text { Minél magasabb ez az arány, annál rugalmasabbnak } \\
\text { tekinthető a munkaerőpiac. }\end{array}$ \\
\hline & Női foglalkoztatási ráta & $\begin{array}{l}\text { A család melletti munkavégzés lehetőségét jelentheti, } \\
\text { ezért a rugalmasabb munkapiacokon magasabb. }\end{array}$ \\
\hline \multirow[b]{2}{*}{ Mobilitás } & $\begin{array}{l}\text { Munkavállalók védelmével } \\
\text { kapcsolatos szabályok } \\
\text { (Employment Protection } \\
\text { Legislation, EPL) }\end{array}$ & $\begin{array}{l}\text { A dolgozók egyéni és kollektív elbocsátás elleni } \\
\text { jogszabályi védelme és az átmeneti foglalkoztatási } \\
\text { formák szabályozása megnöveli a munkáltató } \\
\text { elbocsátásokkal kapcsolatban jelentkező költségeit, } \\
\text { ezért csökkenti a munkaerőpiac rugalmasságát. }\end{array}$ \\
\hline & $\begin{array}{l}\text { Közösségi kiadások a } \\
\text { munkaerőpiaci politikákra a GDP } \\
\text { százalékában }\end{array}$ & $\begin{array}{l}\text { A kormányzati kiadások két csoportja: aktív } \\
\text { munkaeröpiaci politikákra (ALMP) fordított kiadás } \\
\text { (Eurostat 2-7 kategóriák); és a szociális támogatások, } \\
\text { segélyek ( } 8-9 \text { kategóriák). } \\
\text { Utóbbiak növelik a munkapiac rugalmatlanságát, az } \\
\text { ALMP-k viszont nem annyira a rugalmasság, mint } \\
\text { inkább a biztonság dimenzióihoz kapcsolódnak, és } \\
\text { növelik a munkavállalói biztonságot a munkaeröpiacon. }\end{array}$ \\
\hline
\end{tabular}

Forrás: Urbánné Mező-Udvari (2016, 437. o.) saját kiegészítésekkel 
A dolgozatban ezért az Eurostat és az OECD adatbázisainak használata mellett döntöttünk, hiszen az Eurostat biztosítja az Európai Unió országairól a legsokoldalúbb adatokat, azonban vannak olyan témakörök is, amelyeket nem fed le ez az adatbázis - ezekben az esetekben az OECD adatait használjuk. Valójában rendkívül sok mutatót kapcsolhatunk a munkaerőpiaci rugalmassághoz, ahogyan azt a 3.1. táblázat is szemlélteti.

Megismerve a rugalmasság mértékét kifejező indikátorokat, jogosan merül fel a kérdés, hogy milyen szinten tekinthető optimálisnak egy adott munkapiac rugalmassága. A válasz több tényező függvénye. Klau és Mittelstadt 1986-ban megjelent tanulmányukban megállapítják, hogy a merev munkaerőpiacokon különböző ársokkok következtében magas strukturális munkanélküliség alakulhat ki, míg a rugalmas munkaerőpiacok képesek alkalmazkodni a megváltozott keresleti és kínálati feltételekhez, ezért a foglalkoztatás hosszú távon nem esik vissza, vagy legalábbis nem olyan mértékben. Ez alapján gondolhatnánk, hogy minél kevésbé szabályozott a munkaerőpiac, annál jobb. Reed (2010) ezt nevezi „ortodox” vagy „,neoliberális” megközelítésnek, amellyel szemben állnak a „progresszív” vagy „alternatív” nézetek. A szerző statisztikai adatokra alapozva és számos empirikus (statisztikai, ökonometriai) vizsgálat eredményeit sorra véve azt állapítja meg, hogy az ortodox megközelítés a valóságban nem állja meg a helyét, más szóval a kérdés nem egyszerüsíthető le ilyen mértékben.

\subsection{A RUGALMASSÁG HATÁSAI A MUNKAERŐPIACI SZEREPLÖK CSOPORTJAIRA}

Alapvetően a rugalmas munkapiac olyan piacként jellemezhető, ahol relatíve alacsony mértékü az állami beavatkozás, és a piaci folyamatok határozzák meg a foglalkoztatást az állam vagy a szakszervezet nyomása helyett, továbbá gyakori a részmunkaidős foglalkoztatás (Farkas, 2011a; Hárs, 2013; Koncz, 2006). Ebből kifolyólag rugalmas munkaerőpiacon sokkal könnyebb alkalmazni és elbocsátani munkavállalókat. Európában relatíve merev munkaerőpiaccal rendelkezik Franciaország, Ausztria, Finnország vagy Spanyolország, míg relatíve rugalmas a munkaerőpiac az Egyesült Királyságban, Írországban (e kettőben kiemelten rugalmas), Dániában, Svédországban vagy Belgiumban (Farkas, 2011a; 2011b). Általában a flexibilitás előnyeként szokás említeni, hogy a cégek versenyképesebbek lehetnek, mert könnyen el tudják bocsátani a felesleges munkaeröt és könnyebb költséghatékony foglalkoztatási struktúrát kialakítani, és a munkatermelékenység így (is) növekedhet. A rugalmas munkapiac kedvezően hat a nők munkavállalására, a család és a karrier összeegyeztetésére (viszont ez vissza is üthet, amikor a korábbi állás megtartásának biztonságát gyengíti a rugalmasság), valamint alacsonyabb szintü strukturális munkanélküliséget eredményez. A rugalmasság hátránya a továbbképzések minőségének és mennyiségének 
csökkenése a részmunkaidős foglalkoztatás és a gyakoribb munkahely-váltás miatt, valamint nagyobb a foglalkoztatási bizonytalanság és az ezzel járó stressz, továbbá növekedhet a társadalmon belüli jövedelem-egyenlőtlenség, hiszen a bizonytalan foglalkoztatásban alkalmazottak (például a részmunkaidősök) bérének emelkedése általában alacsonyabb.

Ezek alapján elmondható, hogy a munkapiaci rugalmasság a munkaerőpiac különböző szereplőire más-más hatást gyakorol. Ami az egyik csoport számára kedvező, sokszor hátrányosan érint másokat (3.2. táblázat). A rugalmas munkapiacok hozzájárulnak, hogy a vállalatok gyorsan reagálhassanak a növekedési lehetőségekre (BusinessEurope, 2015). Ezzel összhangban áll a World Economic Forum (WEF, 2014) álláspontja, amely szerint a rugalmasabb munkaerőpiaccal rendelkező országoknak nagyobb a versenyképessége. Vannak azonban olyan kutatások, amelyek szerint a munkapiaci szabályozás fontos a munkahelyek minőségének javításában, ösztönzi a munkahelyi képzésekbe történő befektetést és a munkáltató iránti magasabb szintü elkötelezettséget generál, ami növeli a munkavállalók produktivitását (Aleksynska-Cazes, 2014; Almeida-Aterido, 2008; Fenwick et al., 2007). Mindez pedig hozzájárul a versenyképesség javításához. Általában véve mégis az a tapasztalat, hogy a rugalmasság alapvetően a munkaadók érdekeit (profitérdekeit) szolgálja, és sokszor kedvez a munkanélkülieknek is, de a már foglalkoztatásban álló munkavállalókat gyakran hátrányosan érinti. Ez önmagában is megnehezíti a rugalmassági dimenziók hatásainak értékelését, ráadásul a kérdéssel foglalkozó empirikus vizsgálatok tanulságai sem egyöntetűek: a különbségek egyrészt a vizsgált országok körén, másrészt a rugalmasságot kifejező mutatók megragadásán is múlnak (Kahn, 2011; Rodgers, 2007). Mi most elsősorban azt tartjuk szem előtt, hogy ezek a tényezők hogyan hatnak a munkanélküliek munkához jutási lehetőségeire és a foglalkoztatottak azon képességére, hogy megtartsák munkahelyüket.

A munkanélküliek szempontjából azok a körülmények, intézkedések tekinthetőek pozitívnak, amelyek vagy elősegítik számukra az álláshoz jutást, vagy csökkentik a társadalmi leszakadást (szegénységet). A rugalmasságnak a munkanélküliek helyzetére gyakorolt hatását vizsgáló tanulmányok megállapításai nem egységesek. Például Nickell (1997) európai országokra 1980-as és 1990-es évekbeli adatokkal végzett vizsgálatában a mobilitáshoz köthető rugalmassági dimenziókkal kapcsolatban azt állapította meg, hogy a munkanélküli segély nagyságának és folyósítási időtartamának növelése kedvezőtlenül hat a munkanélküliségre, amennyiben nem kapcsolódik hozzá olyan kényszerítő eszköz, amely a munkakeresésre ösztönöz (a helyettesítési hatás következtében); emellett - a bérrugalmassághoz kapcsolódóan - a munkát terhelő magas adók is magas munkanélküliséggel párosulnak. (Bár a munkanélküliek munkához jutását nehezíti, az is igaz, hogy a magasabb adóék teszi lehetővé a 
munkanélküli segély folyósítását, ami pedig a társadalmi leszakadást mérsékli. Hasonlóképpen a magasabb bért kiharcoló szakszervezetek munkája is értelmezhető pozitívumként, azonban a munkanélküliek munkához jutása - mint elsődleges cél - szempontjából mégis inkább nehézséget jelent számukra.) A szerző későbbi, OECD országokra végzett vizsgálata megerősítette ezeket az eredményeket (Nickell, 1998). Nunziata (2002) 20 OECD országot lefedő, 1960-1995-ös időszakra vonatkozó vizsgálatában szintén arra jutott, hogy a munkaerőpiaci intézményeknek közvetlen és szignifikáns hatása van a munkanélküliségre. Eredményei szerint a munkanélküli segély, az adóék, a magasabb szakszervezeti szervezettségi szint, valamint a határozott idejű szerződések szigorú szabályozása (azaz a merev munkapiac) mind magasabb munkanélküliséget eredményeznek. Bernal-Verdugo et al. (2012) 97 országon 1985-2008 közötti adatokra végzett panelvizsgálatában a munkaeröpiaci rugalmasságot kifejező összetett indikátor hat területet fedett le: minimálbér; alkalmazási és elbocsátási szabályozás; központosított kollektív béralku; az alkalmazás költségei; az elbocsátás költségei; végül pedig a sorkatonai szolgálat időtartama. A vizsgálat arra az eredményre vezetett, hogy a munkaerőpiaci rugalmasság növekedése révén szignifikánsan csökkentek a munkanélküliségi mutatók; úgy a teljes, mint az ifjúsági, valamint a hosszú távú munkanélküliségi ráták. ${ }^{24}$

3.2. táblázat A munkaerőpiaci rugalmasság hatása a munkaerőpiac szereplőire

\begin{tabular}{|c|c|c|c|c|}
\hline \multirow{2}{*}{$\begin{array}{l}\text { Rugalmasság } \\
\text { dimenziója }\end{array}$} & \multirow{2}{*}{ Rugalmassági jellemzők } & \multicolumn{3}{|c|}{ Hatása a szereplők csoportjaira } \\
\hline & & munkanélküliek & foglalkoztatottak & munkaadók \\
\hline \multirow{3}{*}{$\begin{array}{l}\text { Bér- } \\
\text { rugalmasság }\end{array}$} & $\begin{array}{l}\text { Átlagkeresethez viszonyított } \\
\text { alacsony reál minimálbér }\end{array}$ & + & - & + \\
\hline & Alacsony adóék & $+1-$ & $+1-$ & + \\
\hline & $\begin{array}{l}\text { Alacsony szakszervezeti } \\
\text { szervezettségi szint }\end{array}$ & + & - & + \\
\hline \multirow{5}{*}{$\begin{array}{l}\text { Munkaidő } \\
\text { rugalmassága }\end{array}$} & $\begin{array}{l}\text { Magas a részmunkaidős } \\
\text { foglalkoztatottak aránya }\end{array}$ & + & + & $+1-$ \\
\hline & $\begin{array}{l}\text { Magas a nem önkéntesen } \\
\text { részmunkaidőben dolgozók aránya }\end{array}$ & + & $+/-$ & + \\
\hline & $\begin{array}{l}\text { Alacsony átlagos heti munkaórák } \\
\text { száma a fóállásban }\end{array}$ & + & $+1-$ & $+1-$ \\
\hline & $\begin{array}{l}\text { Magas a határozott idejü } \\
\text { munkaszerződések aránya }\end{array}$ & + & - & $+1-$ \\
\hline & Magas női foglalkoztatási ráta & + & + & + \\
\hline \multirow{2}{*}{ Mobilitás } & $\begin{array}{l}\text { Gyenge szabályozás a } \\
\text { munkavállalók védelmére }\end{array}$ & + & - & + \\
\hline & $\begin{array}{l}\text { Alacsony közösségi kiadások a } \\
\text { munkaerőpiaci politikákra }\end{array}$ & - & - & - \\
\hline
\end{tabular}

Forrás: Urbánné Mező-Udvari (2016, 438. o.) saját kiegészítésekkel.

${ }^{24}$ Gyakran idézett még Nickell et al. (2005) OECD országokra az 1960-as és 1990-es évek közötti adatokkal végzett empirikus vizsgálata, amely szerint a merev munkaerőpiacok magasabb munkanélküliséget eredményeznek, viszont Vergeer és Kleinknecht (2012) kétségbe vonják a vizsgálat módszertani helyességét. 
Vannak azonban olyan elemzések, amelyek azt igazolják, hogy nem általános, hogy a munkaerőpiac deregulációja jobb gazdasági teljesítményt vagy akár kedvezőbb munkapiaci kimeneteket eredményez. Például egyes makro szintű vizsgálatok alapján a koordinált béralkurendszerek alacsonyabb munkanélküliséggel járnak együtt, és vannak mikro szintü vizsgálatok, melyek alapján nem teljesül, hogy a minimálbér léte magasabb munkanélküliséget okozna (bővebben lásd Reed, 2010). Ennek ellenére még mindig elmondható, hogy túlsúlyban vannak a rugalmasság és munkanélküliség nagysága közötti negatív irányú kapcsolatot alátámasztó vizsgálatok.

A munkapiac rugalmassága a már foglalkoztatásban állók számára jóval kevesebb pozitívumot hordoz magában. A dolgozat 2.1. alfejezetében is utaltunk rá, hogy a rugalmas munkaerőpiac jellemzője, a bizonytalan foglalkoztatás hozzájárul a sebezhető foglalkoztatottak és a dolgozó szegények arányának növekedéséhez. Az Európai Szakszervezeti Szövetség 2015ös éves növekedési jelentésében (ETUC, 2014) fel is hívja rá a figyelmet, hogy a bérek csökkentésére irányuló nyomás és a kollektív alkuk decentralizációja - vagyis a bérrugalmasság növekedése - hozzájárul ahhoz, hogy a munkavállalói szegénység az európai munkaeröpiac strukturális jellemzőjévé válik. A jelentés szerint az esetek felében a munkavállalás nem emeli ki az embereket a szegénységből. A munkaidő rugalmassága, a részmunkaidős állás lehetősége kedvező lehet a munkavállalók számára (ha másképpen nem tudnak elhelyezkedni a munkaerőpiacon), viszont ez nem minden esetben teljesül, hiszen a kényszerü részmunkaidős és határozott idejű munkaszerződések bizonytalanságot eredményeznek és sokszor alacsonyabb fizetéssel járnak. Az adóék szerepe is összetett. Az alacsony adóék egyrészt kedvező a foglalkoztatottak számára, hiszen a nettó fizetésük így magasabb lehet (amennyiben a munkaadó a profit terhére ezt biztosítja); másrészt negatív, hiszen ezek a munkavállalók egészségügyi ellátásának, nyugdíjának, szükség esetén munkanélküli segélyének szolgálnak fedezetül, így ezek csökkenése (alacsony mértéke) negatívan hat e szolgáltatások kiterjedtségére és színvonalára. A dolgozók egyéni és kollektív elbocsátás elleni jogszabályi védelme értelemszerüen erősíti a munkavállalók pozícióját. A munkaerőpiaci politikákra fordított közösségi kiadások (amelyek fedezete részben a munkát terhelő adó és járulék) alapvetően enyhe, de kedvező hatással vannak a foglalkoztatottak helyzetére, mivel a munkanélküliek anyagi helyzetén javító szociális támogatások, segélyek (passzív eszközök) hozzájárulnak a munkakínálat mérséklődéséhez, egyúttal csökkentik a társadalmi feszültségeket. Bár az aktív eszközök éppen a munkakínálat növelése irányába hatnak, általában nem veszélyeztetik a már alkalmazásban állók pozícióját. 
A munkaadók számára a rugalmas munkapiac megteremti a gazdasági változásokhoz való gyors és olcsó alkalmazkodás lehetőségét, így a magas bér- és munkaidő-rugalmasság, valamint a munkavállalók védelmének gyenge szabályozása jelentős költségmegtakarítást jelent. Mindez növeli a vállalatok versenyképességét és nagyobb profitot eredményez $-\mathbf{a z}$ alkalmazottak kiszolgáltatottságának növekedése árán. Mivel a hosszú munkaidő (különösen a heti 40-48 óránál több) csökkentheti a dolgozók termelékenységét, ezért előnyös lehet a munkaadóknak, ha alacsonyabb óraszámban foglalkoztatják munkavállalóikat (Lee et al., 2014). Az aktív munkaerőpiaci politikai kiadások a munkanélküliek mellett a munkaadók számára is előnyösek lehetnek (képzések, alkalmazotti járulék- és adókedvezmény, stb.), hiszen költségmegtakarítást eredményeznek.

\subsection{A MUNKAERŐPIACI RUGALMASSÁG SZEREPE A MUNKANÉLKÜLISÉG ALAKULÁSÁBAN}

A munkaerőpiaci rugalmasságnak nagyon széles szakirodalma van, és az idők során jelentősen változtak a kutatók nézetei a rugalmasságnak a munkanélküliség alakulásában játszott szerepéről. Az ezredforduló előtt és környékén a rugalmas munkaerőpiacot tekintették mérvadónak és kívánatosnak, majd az ezredfordulót követően egyre több kutatás zárult olyan eredménnyel, hogy nem feltétlenül a munkapiaci merevség okozza a magasabb munkanélküliséget. Például amikor Vergeer és Kleinknecht (2012) megismételte Nickell et al. (2005) korábbi, a rugalmas munkapiac mellett érvelő nagy hatású empirikus vizsgálatát, az eredeti megállapításoktól jelentősen eltérő következtetéseket vontak le. ${ }^{25}$ Ezek alapján kétségbe vonják azt a neoklasszikus megközelítést, mely szerint a munkaeröpiaci merevségek növelik a munkanélküliségi rátákat. Bell és Blanchflower (2010, 11-13. o.) ugyancsak azt hangsúlyozzák, hogy az OECD országokra eddig elvégzett ökonometriai vizsgálatok nem bizonyítják, hogy az intézményi merevségek lennének felelősek a munkanélküliségért. A szerzőpáros úgy látja, hogy a 2007-2008-as válság jól rámutatott erre, s, hogy a munkanélküliséget igazán meghatározó tényező a munkakereslet csökkenése, ami pedig az aggregált kereslet visszaesésének köszönhető. Guerazzi és Meccheri (2012) elméleti összefoglaló tanulmányukban szintén megkérdőjelezik, hogy a munkaerőpiaci rugalmatlanságok felszámolása önmagában képes lenne hosszabb távon növelni a foglalkoztatást. Éppen ezért azt hangsúlyozzák, hogy a munkapiac flexibilisebbé tételére irányuló reformoknak aktív munkaeröpiaci politikai eszközöket is tartalmazniuk kell.

${ }^{25}$ Vergeer és Kleinknecht (2012) azért ismételték meg azonos adatbázis használatával a vizsgálatot, mert módszertani hibákat fedeztek fel Nickell et al. (2005) munkájában, nevezetesen a modell nem bizonyult robusztusnak. A becslési eljárásban három feltételt megváltoztatva több vonatkozásban is eltérő eredményeket kaptak, így erősen megkérdőjelezhetővé váltak Nickell et al. (2005) következtetései. 


\section{Ennek ellenére napjainkban is vannak kutatások, amelyek a rugalmasság}

foglalkoztatást növelő szerepét igazolják. Például Köllő (2013) kutatása kimutatta, hogy a 2000-es évek elején egyes európai országokban (elsősorban Írországban, de részlegesen Olaszországban és Spanyolországban is) a munkaerőpiaci rugalmasság növelése jelentősen hozzájárult a foglalkoztatás emelkedéséhez. Zribi et al. (2014) 92 (32 fejlett és 60 fejlődő) országot felölelő, 2000-2010-es adatok alapján végzett panelvizsgálata is megerősítette a rugalmasság és a munkanélküliség közötti kapcsolat meglétét. Statikus modelljükben szinte minden rugalmassági indikátor és a munkanélküliség mutatói között negatív korreláció áll fenn; a dinamikus modell pedig azt mutatja, hogy a munkaerőpiaci szabályozás rugalmasabbá tétele statisztikailag szignifikáns mértékben csökkenti a munkanélküliséget - ez az összefüggés azonban az ifjúsági munkanélküliség esetében nem áll fenn. Agnello et al. (2014) 17 fejlett országra (az 1978-2009 közötti évekre) alkalmazott dinamikus modellje viszont éppen azt mutatta ki, hogy a munkaerőpiaci rugalmasság növelése csökkenti a fiatalok közötti munkanélküliséget - igaz, a szerzők megjegyzik, hogy az ifjúsági munkanélküliséget elsősorban a gazdasági konjunktúra határozza meg. Hasonlóképpen, Breen (2005) 27 OECD országot felölelő (1990-es évekbeli adatokat használó) vizsgálata során empirikusan igazolta, hogy az erősen szabályozott munkaerőpiacokon magasabb az ifjúsági munkanélküliség. Udvari-Urbánné Mező (2015) 25 EU-s tagállamra kiterjedő vizsgálatának ${ }^{26}$ eredménye szerint az ifjúsági munkanélküliség a válság előtti és az azt követő években is ${ }^{27}$ jellemzően alacsonyabb az Európai Unió azon országaiban, ahol elterjedtebbek az atipikus foglalkoztatási formák (ami, mint ismert, a rugalmas munkapiacok jellemzője). Sachs és Smolny (2015) tanulmányukban 17 OECD ország 1982-2005 közötti adatait alapul vevő nemzetközi összehasonlító vizsgálattal és idősorelemzéssel igyekeztek feltárni az intézményi tényezők, a demográfiai helyzet és az oktatási rendszer szerepét a teljes munkanélküliség, valamit különkülön a 15-24 év közötti és a 25 év feletti korosztály munkanélküliségének alakulásában. A vizsgált intézmények egy része - a munkáltatói adók és járulékok, a korosztályos népesség teljes népességen belüli aránya, az oktatásban résztvevők aránya - általában hasonló hatást gyakorolt a három csoportra, de voltak különbségek is. Leginkább a foglalkoztatottak védelmére vonatkozó jogszabályok (különösen a határozatlan idejü szerződések esetében) érintették eltérően a fiatalokat és az idősebbeket: míg a fiatalok körében jelentősen növelték a munkanélküliséget, addig a 25 éven felüliek korosztályát tekintve nem mutatkozott szignifikáns

${ }^{26}$ A vizsgálatban a 28 tagország közül nem szerepelt Horvátország, Ciprus és Málta.

${ }^{27}$ A válság előtti időszakot reprezentálják a 2005-2007-es évek adataiból számított számtani átlagok, a válság utánit pedig a 2011-2013-as adatok. 
kapcsolat (ez erősíti a bennfentes/kívülálló megközelítés megállapításait). Másrészt a szakszervezetekre és a béralku rendszerre is összességében az adódott, hogy az idősebb munkavállalókat védik, és hátrányos helyzetbe hozzák a fiatalokat. A munkanélküli segélyek hatását tekintve a 25 év felettiek esetében mutatkozott pozitív összefüggés a segély és a munkanélküliség nagysága között, a fiataloknál nem. Szintén a munkaerőpiaci rugalmasság generációspecifikus hatását vizsgálta Urbánné Mező-Udvari (2016). 2014-es adatokkal 28 OECD országra ${ }^{28}$ végezték el elemzésüket, amely szerint bár a rugalmas munkaerőpiacok egyes jellemzői eltérően hatnak a fiatalabb és az idősebb korosztály foglalkoztatására, összességében nem mondható el, hogy a nagyobb rugalmasság valamely korosztályt sokkal kedvezőbb pozícióba hozná a munkaerőpiacon. Az eredményeik szerint az átlagosnál rugalmasabb munkapiacokra többnyire az átlagosnál jobb munkapiaci kimenetek jellemzőek, és ez az összefüggés leginkább a felnőtt (25-54 éves) korosztály esetében érvényes, ennél valamelyest kevésbé a 25 évnél fiatalabbak, legkevésbé pedig az idősek (55-64 évesek) körében.

Ezen ellentmondásos eredmények hátterében (a módszertani eltéréseken és esetleges hibákon túl) az állhat, hogy a rugalmasságnak több vetülete van, melyek közül némelyek kedveznek a dolgozóknak (például megkönnyítik a munkaerő felvételt a vállalatok számára), mások viszont hátrányosan érintik a munkavállalókat (például megkönnyítik a munkáltatók számára az elbocsátásokat). A hasonló empirikus vizsgálatok értékelésekor ezért szem előtt tartandó, hogy azok eredményeit alapvetően befolyásolja a vizsgálni kívánt országok és a rugalmasság nagyságát kifejező mutatók meghatározása. Az is segítheti a pontosabb következtetések levonását, ha a rugalmasság dimenzióinak egy szűkebb társadalmi csoport foglalkoztatására való hatását vizsgáljuk. Ez is indokolja azt, hogy a dolgozatban az ifjúsági munkanélküliségre fókuszálunk.

A rugalmasságnak vannak előnyei és árnyoldalai is, és - ahogyan azt korábban is láttuk - a munkaerőpiaci rugalmasságnak számos különböző vetülete van, melyek más-más módon hatnak a munkaerőpiac különböző szereplőire, így eltérő mértékben befolyásolják a munkaerőpiaci kimeneteket is (Bernal-Verdugo et al., 2012; Nickell, 1997; OECD, 2013; Rodgers, 2007). Mivel a munkapiac távolról sem tekinthető tökéletesen versenyzőnek, ezért - szociális szempontok figyelembe vétele érdekében - valamilyen szintü szabályozása mindenképpen szükséges. Különösen igaz ez a jól megtervezett aktív munkaerőpiaci politikai eszközök alkalmazására, melyek jelentős szerepet töltenek be a munkaerőpiaci hatékonyság mellett a munkavállalói biztonság és a társadalmi méltányosság

\footnotetext{
${ }^{28}$ Adathiány miatt Kanada, Chile, Japán, Korea, Mexikó és Svájc kimaradt a vizsgálatból.
} 
megteremtésében is (Kim, 2009; Lee et al., 2014). Emellett a munkavállalók védelmét szolgáló szabályozásnak nagy szerepe van a gazdasági visszaesések társadalomra gyakorolt negatív hatásainak enyhítésében (Lee et al., 2014). Ezek miatt terjedt el az utóbbi két évtizedben a flexicurity koncepciója Európában (Viebrock-Clasen, 2014).

\subsection{A FLEXICURITY ÉS MÉRÉSE}

Miután világszerte egyre terjednek az atipikus foglalkoztatási formák és ezáltal a bizonytalan foglalkoztatás, egyre fontosabbá válik a mindenki számára tisztességes munka megteremtése is. Az ILO 1999-es kezdeményezéséhez, amelyben megalkotta a tisztességes munka (decent work) koncepcióját, az Európai Unió is csatlakozott. ${ }^{29}$ Ennek megvalósításában nagy szerepe lehet a flexicurity rendszernek. A kifejezés a rugalmas munkaerőpiaci szabályok és a biztonságot nyújtó szociális védelem kombinációját jelöli. Magyar fordításai a rugalmas biztonság és a biztonságos rugalmasság. Az Európai Bizottság definíciója szerint a flexicurity olyan integrált munkaerö-piaci stratégia, amely a munkaerőpiaci rugalmasság és biztonság egyidejü erősitésére irányul (Európai Bizottság, 2007). Ez a megközelítés túllép a rugalmasrugalmatlan skálán és a rugalmas-biztonságos végpontok közötti osztályozáson alapul - a munkavállalók védelmét szolgáló munkajogi szabályok, a kollektív munkajogi szabályok és a szociális védelem mértéke alapján (Auer, 2007; Sharkh, 2008; Viebrock-Clasen, 2014). A munkaerőpiaci rugalmasság a gazdasági termelékenység és versenyképesség növelését, valamint a munkahelyteremtést segíti, míg a biztonságnak a társadalmi kohézió megőrzésében, a hátrányos helyzetben lévő csoportok leszakadásának megelőzésében van jelentősége (Manca et al., 2010). A szociális transzfereknek nagy szerepe van a (mély)szegénység csökkentésében, éppen ezért az Európai Szakszervezeti Szövetség is ezek fenntartása mellett (és a fiskális megszorító intézkedések ellen) érvel (ETUC, 2014). A flexicurity rendszerek első bevezetői Dánia és Hollandia. Nem véletlen tehát, hogy a koncepció népszerűvé vált az EU-ban és az

\section{Európa 2020 stratégia részeként az Európai Foglalkoztatási Stratégiában is megjelenik,} azzal, hogy azt a tagállamoknak saját körülményeikhez kell igazítani.

A munkaerőpiaci rugalmasság jellemzőit és összetevőit korábban részletesen ismertettük. A szociális biztonság kiterjedtségét a következő - egymással összefüggő - kritériumokkal lehet értékelni (Keller-Seifert, 2005):

- a foglalkoztatásból származó jövedelemnek elégségesnek kell lennie az önálló megélhetés biztosításához, a társadalombiztosítási járulékoknak pedig biztosítaniuk

\footnotetext{
${ }^{29}$ http://eur-lex.europa.eu/legal-content/EN/TXT/?uri=celex:52006DC0249
} 
kell a nyugdíjjogosultságot és a munkanélküli segélyre szóló jogosultságot munkanélküliség esetén,

- a foglalkoztathatóság (employability) fenntartása és javítása céljából biztosítani kell az élethosszig tartó tanulás, a képzéseken való részvétel lehetőségét;

- szolidaritási alapon működő egészségbiztosítási rendszer szükséges.

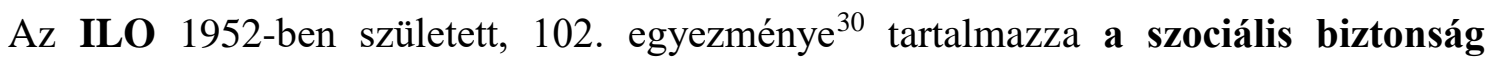
minimális standardját, vagyis azokat a minimumkövetelményeket, amelyeket be kell tartani a szociális biztonság megteremtése érdekében. Ilyenek az egészségügyi ellátás, táppénz, munkanélküli segély, öregségi nyugdíj, munkahelyi baleset utáni pótlék, családi támogatás (gyermeknevelési támogatás), anyasági ellátás, rokkantsági és özvegyi ellátás. Az egyezményt 56 ország ratifikálta. A minimumkövetelményekhez hasonló, az ILO által létrehozott eszköz még a nemzeti szinten meghatározott szociális védelmi minimumról szóló 202. ajánlás (2012), a szociális biztonság területén a belföldi és külföldi állampolgárok közötti egyenlő bánásmódot előíró 118. egyezmény (1962), valamint a társadalombiztosítási jogok érvényesítése nemzetközi rendszerének a megteremtéséről szóló 157. egyezmény (1982). ${ }^{31}$

A gyakorlatban nehéz feladat a rugalmasság és a (munkahelyi és szociális) biztonság egyidejü megvalósítása, hiszen e kettő tartalmi ellentmondásai nem elhanyagolhatóak. Nem tévedés azt állítani, hogy a biztonság nem egyenlő a rugalmatlansággal, de be kell látni, hogy a munkavállalók védelmét szolgáló szabályok a rugalmatlanság felé terelik a munkaerőpiacot. Éppen ezért a flexicurity rendszerek egyik sarokköve, hogy elsősorban a (Keller és Seifert [2005] osztályozása szerinti) belső rugalmasság elemeit erősítik a külső (létszámot befolyásoló) rugalmassággal szemben, de közben kevésbé szigorúak a munkavállalók védelmével kapcsolatos szabályok (EPL) is. A másik fontos cél az atipikus foglalkoztatási formákkal járó bizonytalanságok csökkentése: például a munkanélküli segély rendszerével; az aktív munkaerőpiaci politikákkal; a vállalatokon belüli és kívüli képzésekhez való hozzájutás támogatásával; valamint a későbbi nyugdíj összegének növelése érdekében a szolgálati idő és nyugdíjalapot képező jövedelem szerzésére irányuló megállapodás kötésének lehetőségével (Keller-Seifert, 2005). Boeri et al. (2012, 685. o.) úgy fogalmaznak, hogy a rugalmas biztonság rendszereiben a figyelem a munkanélküliek támogatására irányul, nem pedig a munkahelyek védelmére - különösen azokban az országokban, ahol nagyobb a (magasan)

30 Social Security (Minimum Standards) Convention, 1952 (No. 102), http://www.ilo.org/dyn/normlex/en/f?p=NORMLEXPUB:12100:0::NO::P12100_INSTRUMENT_ID:312247

31 http://ilo.org/global/standards/subjects-covered-by-international-labour-standards/social-security/lang-$\underline{\text { en/index.htm }}$ 
képzett munkaerő aránya. Ezért is bír nagy jelentőséggel a flexicurity rendszerekben a tanulási lehetőségek növelése.

Ahogyan magának a munkapiaci rugalmasságnak, a rugalmas biztonságnak sem létezik egyetlen ideális szintje. Sharkh (2008) 27 OECD és 57 nem OECD országot lefedő, flexicurity rendszerek elemzésével foglalkozó empirikus vizsgálata alapján megállapítja, hogy nincs egyszerü lineáris kapcsolat a munkapiaci rugalmasság és a kívánatos társadalmigazdasági teljesítmény között, hiszen a rugalmasabb munkaerőpiacok esetében általában kedvezőbbek a munkapiaci hatékonysági kimenetek (például alacsonyabb a munkanélküliség), viszont a kiterjedtebb szociális védelmet biztosító országokban alacsonyabbak a szegénységet és a társadalmi különbségeket mérő indikátorok értékei. Rodgers (2007) arra is felhívja a figyelmet, hogy más nemzeteknek mások lehetnek a preferenciái: egyes társadalmakban a mobilitásnak tulajdonítanak nagyobb értéket, másokban viszont a stabilitásnak.

A szokásosan alkalmazott munkaerőpiaci rugalmassági indikátorok mellett Manca et al. (2010) kidolgoztak egy négy komponensböl álló összetett mutatót a flexicurity mérésére is, (ezek áttekintését adja a 3.3. táblázat, ezáltal egyben segíti a flexicurity különböző vetületeinek teljesebb megértését is). A szerzők a komponensek összetevőit az Európai Bizottság által meghatározott négy dimenzió mentén határozták meg:

1. egész életen át tartó tanulás (Lifelong Learning, LLL): biztosítja a munkavállalók folyamatos alkalmazkodóképességét és foglalkoztathatóságát, különösen a leginkább sebezhető csoportokban;

2. aktív munkaerőpiaci politikák (Active Labour Market Policies, ALMP): segítenek a sokkokhoz való alkalmazkodásban, lerövidítik a munkanélküliséget és megkönnyítik az állások közötti átmenetet;

3. modern társadalombiztosítási rendszerek (Modern Social Security Systems, MSS): ösztönzik a munkavállalást a munka és a magánélet összehangolásának segítésével és széles körben kiterjesztik a szociális védelmi rendszereket;

4. rugalmas és megbízható szerződéses megállapodások (Flexible and Reliable Contractual Arrangements, FCA): korszerü munkajogi jogszabályok, kollektív szerződések és munkaszervezés. 
3.3. táblázat A flexicurity mérésére alkalmas mutatók

\begin{tabular}{|c|c|c|}
\hline $\begin{array}{l}\text { Az összetett } \\
\text { indikátor } \\
\text { komponensei }\end{array}$ & A komponensek dimenziói & $\begin{array}{l}\text { Almutatók } \\
\text { száma }\end{array}$ \\
\hline \multirow{4}{*}{$\begin{array}{l}\text { Egész életen át } \\
\text { tartó tanulás }\end{array}$} & Továbbképzéseket nyújtó vállalatok százalékos aránya & 1 \\
\hline & Részvétel a továbbképzéseken & 3 \\
\hline & Továbbképzések költségei & 3 \\
\hline & $\begin{array}{l}\text { Egész életen át tartó tanulás (25-64 éves férfi és női lakosság képzésben } \\
\text { való részvétele) }\end{array}$ & 2 \\
\hline \multirow{3}{*}{$\begin{array}{l}\text { Aktív } \\
\text { munkaerőpiaci } \\
\text { politikák }\end{array}$} & ALMP kiadások a GDP százalékában & 7 \\
\hline & Résztvevőkre jutó ALMP kiadások (millió euróban) & 6 \\
\hline & Aktivizálási törekvések hatékonysága & 3 \\
\hline \multirow{4}{*}{$\begin{array}{l}\text { Modern } \\
\text { társadalom- } \\
\text { biztosítási } \\
\text { rendszerek }\end{array}$} & $\begin{array}{l}\text { A munkanélküli-segéllyel való lefedettség és a segélyre fordított } \\
\text { kiadások összege }\end{array}$ & 3 \\
\hline & Pénzügyi ösztönzők a munkavállalásra (adókulcsok hatása) & 5 \\
\hline & Egyéni munkanélküli segélyezés összege és hossza & 6 \\
\hline & Gyermekgondozási szolgáltatások & 6 \\
\hline \multirow{3}{*}{$\begin{array}{l}\text { Rugalmas és } \\
\text { megbízható } \\
\text { szerződéses } \\
\text { megállapodások }\end{array}$} & $\begin{array}{l}\text { Elbocsátások szabályozása és rugalmas szerződések alkalmazása (külső } \\
\text { rugalmasság) }\end{array}$ & 6 \\
\hline & A munkaidő rugalmassága (belső rugalmasság) & 10 \\
\hline & $\begin{array}{l}\text { Munkaszervezés rugalmassága a családi és munkahelyi feladatok } \\
\text { összeegyeztetésének segítése érdekében }\end{array}$ & 3 \\
\hline
\end{tabular}

Megjegyzés: az almutatók nem egyforma súlyozással szerepelnek az összetett indexekben; minél magasabb értéket vesznek fel a mutatók, annál nagyobb a rugalmas biztonság, kivéve az FCA mutatói többségének esetében.

Forrás: Manca et al. (2010) alapján saját szerkesztés.

Ezek alapján Manca et al. (2010) 2004-2008-as adatokat alapul véve az EU országait ${ }^{32}$ öt földrajzi klaszterbe sorolták a flexicurity megvalósításának eredményessége alapján:

- északi: Dánia, Svédország és Finnország;

- kontinentális: Hollandia, Luxemburg, Franciaország, Németország, Ausztria, Belgium;

- mediterrán: Görögország, Spanyolország és Portugália;

- angolszász: Egyesült Királyság és Írország; és

- új tagállamok: Románia, Észtország, Lettország, Litvánia, Lengyelország, Csehország, Szlovákia, Szlovénia, Magyarország, Ciprus, Málta.

A legsikeresebbek az északi országok, a legkisebb mértékben az új tagállamok alkalmazzák a flexicurity rendszereket, a további klaszterekben pedig eltérő az államok teljesítménye.

Mint már említettük, a flexicurity rendszerek iskolapéldáiként Dániát és Hollandiát szokás megnevezni. Viebrock és Clasen (2014) részletesen ismertetik, hogy e két országban miként müködik a felxicurity rendszere. Dániában a rugalmas munkaerőpiac, bőkezü munkanélküli ellátások és az aktiválás hangsúlyos szerepe jelenti a flexicurity három, jól összehangolt elemét. Ebben az elbocsátással szembeni gyenge védelmet bőkezü munkanélküli

${ }^{32}$ Manca et al. (2010) vizsgálatában az LLL indikátor 23, az ALMP 24, az MSS 25, az FCA 23 tagállamra került kiszámításra. 
segély és a foglalkoztathatóság javítását célzó aktív munkaerőpiaci politika és az élethosszon át tartó tanulás lehetősége (képzés és átképzés) kompenzálja. Hollandiában a ,flexicurity legfontosabb jellemzöje az atipikus, rugalmas jellegü munka és a szabályos munkarendben foglalkoztatott dolgozók jogositványaihoz hasonló szociális biztonsággal kapcsolatos jogok kombinálása" (Viebrock-Clasen, 2014, 28. o.). Az aktív munkaerőpiaci programok kiterjesztésével az 1990-es évek végétől Hollandiában javult a határozott időre alkalmazott és a részmunkaidős dolgozók helyzete a szociális védelem tekintetében; miközben a szabályos foglalkoztatásban csökkent az elbocsátással szembeni védelem mértéke.

Összességében elmondható, hogy a rugalmatlanság sok esetben korlátozza a munkaerőpiac dinamikáját (azaz a munkaadók és munkavállalók számára kölcsönösen előnyös szerződések megkötését célzó tárgyalásokat), és így alacsonyabb foglalkoztatáshoz vezethet. Ennek a leginkább kitett, veszélyeztetett csoportok a fiatal pályakezdők, a (családos) női munkavállalók, a tapasztalatlan és alacsonyan képzett munkanélküliek, valamint a más okból alacsonyabb termelékenységü munkavállalók (Elgrably-Lévy, 2006). Mégis, a munkapiacok müködésének összetettségét és a flexicurity rendszerek sikerességét szem előtt tartva azt mondhatjuk, hogy nem létezik a munkapiaci rugalmasságnak egy olyan ideális szintje, amely minden szempontból kívánatos lenne. Adott társadalmi és gazdasági kimenetek elérését elősegítheti egy rugalmasabb vagy éppen egy erősebben szabályozott munkaerőpiac - hogy ezek közül melyik, az a konkrét céltól függ. Emellett nagy jelentősége van annak, hogy a munkaeröpiacot társadalmi kontextusban értelmezzük, figyelembe véve az adott országban uralkodó társadalmi normákat, értékeket. A munkapiaci flexibilitás jelentőségének pontosabb vizsgálatát segíti, ha azonosítunk egy kisebb csoportot, amelyre vonatkoztatni szeretnénk a különböző rugalmassági dimenziók hatásait. A dolgozatban a fiatal korosztály helyzetével foglalkozunk, ezért a következő fejezetben az ifjúsági munkanélküliség témáját járjuk körül. 


\section{Az IFJÚSÁGI MUNKANÉLKÜLISÉG}

Az Európai Unió munkaerőpiaci kategóriáit a szemlélteti a 4.1. ábra. Az Eurostat (2017) adatai szerint 2016-ban az Európai Unió 28 országában 4,24 millió 15-24 év közötti (és további 2,93 millió 25-29 év közötti) fiatal munkanélkülit regisztráltak. A 15-24 évesek munkanélküliségi rátája 18,7 százalék, a teljes népességre vetített munkanélkülsiégi ráta pedig 8,5 százalék volt. Az összes munkanélkülinek több, mint 20 százaléka a 25 évesnél fiatalabbak közül került ki. Ugyanebben az évben az Amerikai Egyesült Államokban a 15-24 évesek ifjúsági munkanélküliségi rátája 10,4 százalék volt, és 2,21 millió 15-24 éves fiatal volt munkanélküli (összesen pedig 7,75 millió fö, a teljes munkanélküliségi ráta pedig 4,9\%). 2016-ban az EU 28 országában a 15-24 éves népesség 11,5 százaléka volt NEET, vagyis csaknem 6,3 millió 15-24 éves fiatal nem volt foglalkoztatott és nem is tanult.

4.1. ábra Fiatalok az Európai Unió munkapiacán (2016-os adatok; ezer fö)

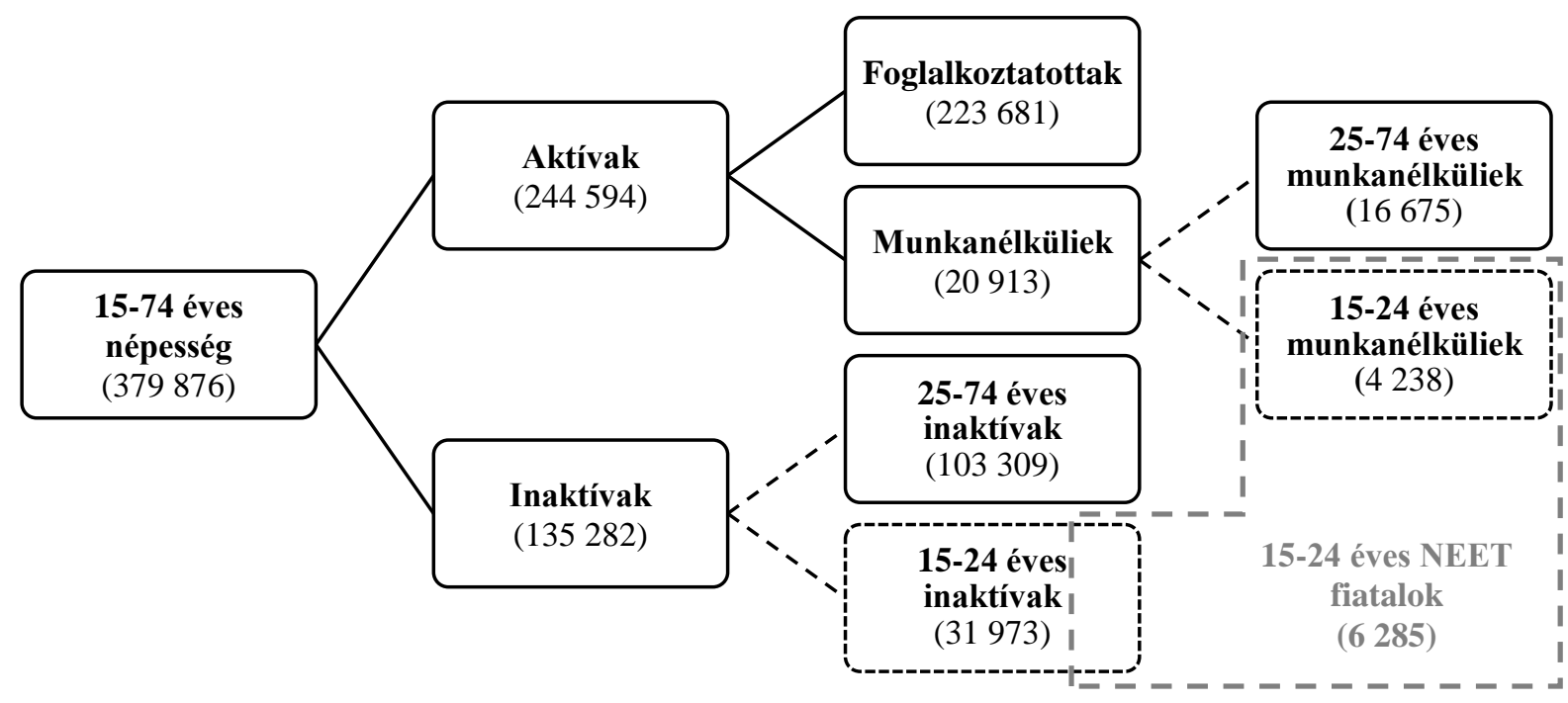

Forrás: Eurostat (2017) adatai alapján saját szerkesztés.

Az ifjúsági munkanélküliség mérésére leggyakrabban használt indikátorok értékének a 2007-2008-as válság alatti változását mutatja be a 4.1. táblázat, amelyből az is kitünik, hogy mindhárom mutató értéke jelentősen megemelkedett a válság következtében. A mélypont 2013ban jött el, de még 2016-ban is magasabbak voltak a munkanélküliség mutatószámai, mint a válság kirobbanása előtt (2007-ben). 
4.1. táblázat Az ifjúsági munkanélküliséget leíró, leggyakoribb mutatószámok

\begin{tabular}{|c|c|c|c|c|}
\hline \multirow{2}{*}{ Indikátor } & \multirow{2}{*}{ Kiszámítási módja } & \multicolumn{3}{|c|}{ Értéke az EU 28-ban } \\
\hline & & 2007 & 2013 & 2016 \\
\hline $\begin{array}{l}\text { Ifjúsági } \\
\text { munkanélküliségi } \\
\text { ráta (\%) (IMNR) }\end{array}$ & $\frac{15-24 \text { éves munkanélküliek száma }}{15-24 \text { éves aktív népesség }}$ & $15,9 \%$ & $23,7 \%$ & $18,7 \%$ \\
\hline $\begin{array}{l}\text { Ifjúsági } \\
\text { munkanélküliségi } \\
\text { arány }(\%)\end{array}$ & $\frac{15-24 \text { éves munkanélküliek száma }}{15-24 \text { éves népesség }}$ & $6,8 \%$ & $9,9 \%$ & $7,8 \%$ \\
\hline NEET ráta (\%) & $\begin{array}{l}\text { 15-24 éves nem foglalkoztatott, oktatásban } \\
\text { és képzésben nem részesülök száma } \\
15-24 \text { éves népesség }\end{array}$ & $11,0 \%$ & $13,0 \%$ & $11,5 \%$ \\
\hline $\begin{array}{l}\text { Fiatal munka- } \\
\text { nélküliek összes } \\
\text { munkanélkülin } \\
\text { belüli aránya }(\%)\end{array}$ & $\frac{15-24 \text { éves munkanélküliek száma }}{15-74 \text { éves munkanélküliek száma }}$ & $24,7 \%$ & $21,4 \%$ & $20,3 \%$ \\
\hline
\end{tabular}

Forrás: Eurostat (2017) adatai alapján saját szerkesztés.

A továbbiakban részletesebben bemutatjuk az ifjúsági (és a teljes) munkanélküliség alakulását az elmúlt évek során az Európai Unióban. Így látható lesz, hogy a munkanélküliség valóban magas arányú a fiatalok körében. Ezt követően ismertetjük az ifjúsági munkanélküliség hatásait, amelyek igen jelentősek és nem csak a fiatalokat érintik, ezért különösen indokolt ezzel a problémával foglalkozni. Ezután összefoglaljuk azokat a tényezőket, amelyeket a szakirodalom az ifjúsági munkanélkülség hátterében húzódó okokként azonosít, és amelyek feltárása és megfelelő kezelése segítheti a fiatalok munkaerőpiaci helyzetének javítását.

\subsection{A MUNKANÉLKÜLISÉG ÉS AZ IFJÚSÁGI MUNKANÉLKÜLISÉG ALAKULÁSA AZ EURÓPAI UNIÓBAN}

Európában a munkanélküliség az 1970-es évek óta kezdett emelkedni, és azóta is viszonylag magas maradt - legalábbis az Amerikai Egyesült Államokban tapasztalható rátákhoz képest. Ennek forrásaként a kutatók az európai munkapiaci merevségeket szokták megjelölni. Azonban ebből a szempontból Európa nem egységes: egyes országokban alacsony, másokban magas a munkanélküliségi ráta. Söt, az egyes országokon belüli regionális különbségek sem elhanyagolhatóak. A régiók gazdasági fejlettségbeli különbségei mellett meghatározóak a munkaerőpiaci intézményi eltérések is.

Ebben az alfejezetben ${ }^{33}$ bemutatjuk az európai munkanélküliség történeti alakulását az Amerikai Egyesült Államokéval összevetve, és az EU munkapiacainak olyan általános jellemzőit, melyek a magas munkanélküliség állandósulásához vezettek. Külön figyelmet

\footnotetext{
${ }^{33}$ A kifejtés során nagymértékben támaszkodunk Blanchard (2006) munkájára.
} 
szentelünk a 2008-as válság következményeinek, melyek felhívták a figyelmet az európai országok munkaerőpiacainak strukturális problémáira.

4.2. ábra A munkanélküliségi ráta alakulása az EU 28 országában és az USA-ban (19632015;\%)

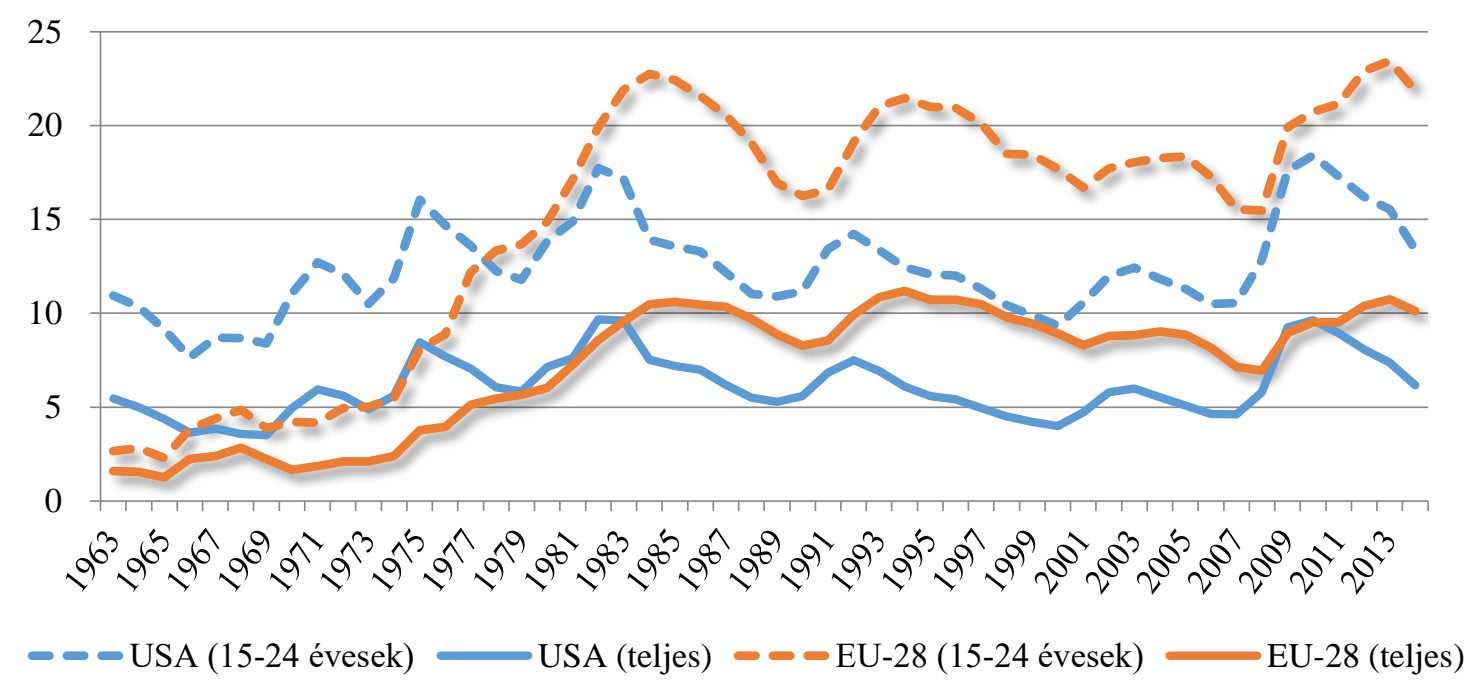

Forrás: OECD.Stat (2016) adatai alapján saját szerkesztés.

Európában a munkanélküliségi ráta az 1960-as években még kifejezetten alacsony volt és ez magas gazdasági aktivitással is párosult (4.2. és 4.3. ábra). Az 1970-es évek olajárrobbanásai következtében a munkanélküliség viszont növekedésnek indult és az 1980-as évek közepéig növekedett, míg az Egyesült Államokban már az évtized elején csökkenni kezdett (Blanchard, 2006; Horváth, 2006; Jimeno-Rodríguez-Palenzuela, 2002). Európában a munkanélküliség 1970-es évektől kezdődő fellendülésének hátterét több kutatás is vizsgálta és ezáltal az idő előrehaladtával egyre több tényező szerepére derült fény. Blanchard (2006) munkájában rövid történeti összefoglalást ad a közgazdászok körében elterjedt különböző magyarázatokról. Az 1980-as évek első feléig két sokk jelentőségét emelték ki: egyrészt az olaj árának világpiaci megugrásait (1973-74-ben és 1979-80-ban), mely az egész világgazdaságra hatással volt; másrészt pedig a teljes tényezőtermelékenység (total factor productivity, TFP) növekedésének lelassulását. A szerző megállapítja, hogy az 1950-es és '60-as években 5 százalékot is meghaladó Harrod-neutrális technikai fejlődés az 1970-es évek végére 2 százalékosra lassult, s ennek következtében a munkabéreknek is csökkenniük kellett volna, de a kollektív alku és a társadalmi ellenállás ezt megakadályozta, s így elkerülhetetlen lett a munkanélküliség növekedése. Horváth (2006, 746. o.) mindemellett felhívja a figyelmet az ebben az időben az európai munkapiacokon bekövetkezett intézményi változásokra is: a „,szakszervezeti tagság és alkupozíció növekedett, több országban növekedett a minimálbér és 
a munkanélküli-segély nagysága, munkahelyvédö intézkedéseket vezettek be (például magas végkielégitési kötelezettséget)."

Az egyes országok közötti különbségek okát keresve Blanchard (2006, 16. o.) Bruno és Sachs 1985-ben megjelent könyvéböl kiemeli azt a megállapítást, hogy a munkanélküliség nagysága magyarázható azzal, ahogyan a gazdasági sokkok „találkoznak” a reálbérek és nominálbérek merevségeivel. A reálbérek merevsége a reálbéreknek az indokolt szinthez való alkalmazkodásának sebességét jelenti. Minél lassabban megy végbe egy sokkot követően ez az alkalmazkodási folyamat, annál magasabb és hosszabb ideig tartó lesz a munkanélküliség. Ezzel szemben a nominálbérek merevségének a nominálbérek változásának az árszínvonalváltozásokat követő sebessége tekintendő. Az infláció szintjétől elmaradó nominálbérnövekedés alacsonyabb reálbért eredményez, így a monetáris hatóságok az infláció eszközével élve feltartóztathatják a munkanélküliség további növekedését. A reál- és nominálbérek rugalmatlanságának eltérései ekképpen magyarázhatják, hogy a különböző országokban miért okoznak hasonló sokkok eltérő mértékü munkanélküliség-növekedést.

Blanchard (2006, 16. o.) szerint Európában az 1980-as évek első felében is magas szinten maradó munkanélküliség eleinte az inflációt leszorító szigorú monetáris politikáknak volt köszönhető. Az infláció stabilizálódását követően azonban a munkanélküliség természetes szintje továbbra is magas maradt (az EU 15-ben 8-9\%). Ennek az eddigiekhez adódó okaiként a kutatók a tőkefelhalmozás ${ }^{34}$ és a kollektív alkuk mechanizmusait jelölték meg. Elterjedt az elmélet, hogy a magas munkanélküliség megnöveli az állással rendelkező munkavállalók alkuerejét a cégekkel szemben, így ők magasabb béreket tudnak kiharcolni, amelyek mellett viszont a vállalatok kevesebb munkaerőt alkalmaznak (Blanchard, 2006; Horváth, 2006). Ehhez hozzájárult még, hogy Európára jellemző a hosszú távú munkanélküliség magas aránya: az egy éven túli munkanélküliség alatt a humán tőke minősége romlik, a sokáig állás nélkül maradt emberek nehezebben reintegrálhatók a munkaerőpiacra.

Az 1990-es években továbbra is magas maradt a munkanélküliség, de egyre nagyobb különbségek mutatkoztak az országok között. Ez felhívta a figyelmet az intézményi különbségek szerepére: nagy hatású Jobs Study címü tanulmányában a Gazdasági Együttmüködési és Fejlesztési Szervezet a munkaerőpiaci merevségeket teszi központi felelőssé az európai munkanélküliségért (OECD, 1994). Úgy tünt például, hogy a munkavállalók védelmét szolgáló szabályok (EPL) tekinthetők a tartós munkanélküliség fő kiváltó okának Európában (Blanchard, 2006, 26. o.). Bell és Blanchflower (2010, 11-13. o.)

\footnotetext{
${ }^{34}$ Magasabb reálkamatláb csökkenő beruházásokat, s ezen keresztül csökkenő foglalkoztatást eredményez.
} 
ellenben már azt hangsúlyozzák, hogy a korábban elfogadott nézet, mely szerint az intézményi merevségek tehetők felelőssé a munkanélküliségért, empirikusan nem nyert megfelelő bizonyítást az OECD országokra eddig elvégzett ökonometriai vizsgálatok alapján. A szerzőpáros úgy látja, hogy a 2007-2008-as válság jól rámutatott erre, s, hogy a munkanélküliséget igazán meghatározó tényező a munkakereslet csökkenése, ami pedig az aggregált kereslet visszaesésének köszönhető. Nunziata (2002) OECD országokra vonatkozó vizsgálata sem önmagában az intézményi különbségek szerepére hívja fel a figyelmet, hiszen eredményei szerint a munkaerőpiaci intézményi változások hozzávetőleg 55 százalékban magyarázták az európai munkanélküliség az 1960-as és 1990-es évek első fele között tapasztalható növekedését, a fennmaradó részért pedig a gazdasági visszaesés volt a felelős.

A munkapiaci intézmények országok közötti összehasonlítása kvantitatív eszközökkel nagyon nehéz feladat, hiszen minden esetben egyedi és többdimenziós intézményekről van szó (Blanchard, 2006). Mégis, kellő óvatossággal lehet általános megállapításokat tenni az európai munkapiacra vonatkozóan, illetve csoportosíthatóak az európai országok aszerint, hogy a válság milyen mértékben sújtotta őket a foglalkoztatás alakulása szempontjából. Farkas (2011a) például a munkapiaci rugalmasság foglalkoztatáspolitikai közkiadásokkal vett kapcsolata alapján öt klaszterbe sorolta az általa vizsgált 25 EU-s tagállamot. ${ }^{35} \mathrm{Az}$ összes posztszocialista ország Szlovénia kivételével, valamint Görögország és Olaszország egy csoportot képez. Itt a foglalkoztatás átlag alatti, a munkapiacok közepesen merevek, a bérek járulékos költségei átlag felettiek. Az aktív munkapiaci eszközökre keveset, a passzívakra sokat költenek. A szakszervezeti szervezettség szintje alacsony. A második klasztert Dánia, Svédország és Belgium alkotja. Itt a magas foglalkoztatottság rugalmas munkapiacokkal párosul, emellett az állam mind az aktív, mind a passzív munkapiaci eszközökre sokat költ. A szakszervezeti szervezettség szintje nagyon magas. Hollandia egyedül van a harmadik klaszterben, amely hasonlít a másodikra, viszont itt még rugalmasabb a munkaerőpiac. A negyedik klasztert Ausztria, Finnország, Franciaország, Luxemburg, Németország, Portugália, Spanyolország, valamint Szlovénia alkotja. Itt a foglalkoztatás az EU átlaga körül mozog, a munkapiacok rugalmatlanabbak, a bérek járulékos költségei magasak. Az aktív munkapiaci kiadások közepesnek mondhatóak, azonban a passzívakra sokat fordítanak - de az előző két klaszternél kevesebbet. A szakszervezeti szervezettség szintje közepes. Az ötödik az angolszász klaszter:

${ }^{35}$ Ez az elemzés ösztönözte a dolgozat harmadik hipotézisének megfogalmazását, amely szerint az Európai Unió tagállamaiban az ifjúsági munkanélküliség nagysága és a munkaerőpiaci politikákra fordított állami költségvetési kiadások összege között nincs egyértelmü kapcsolat. 
az Egyesült Királyság és Írország tartozik ide. A foglalkoztatás magas, a munkapiac nagyon rugalmas. A munkapiaci közkiadások igen alacsonyak, kivéve az információs szolgáltatásokra fordítottakat. A szakszervezeti szervezettség pedig közepes szintü.

4.3. ábra Az aktivitási ráta alakulása az EU 28 országában és az USA-ban (1963-2015; \%)

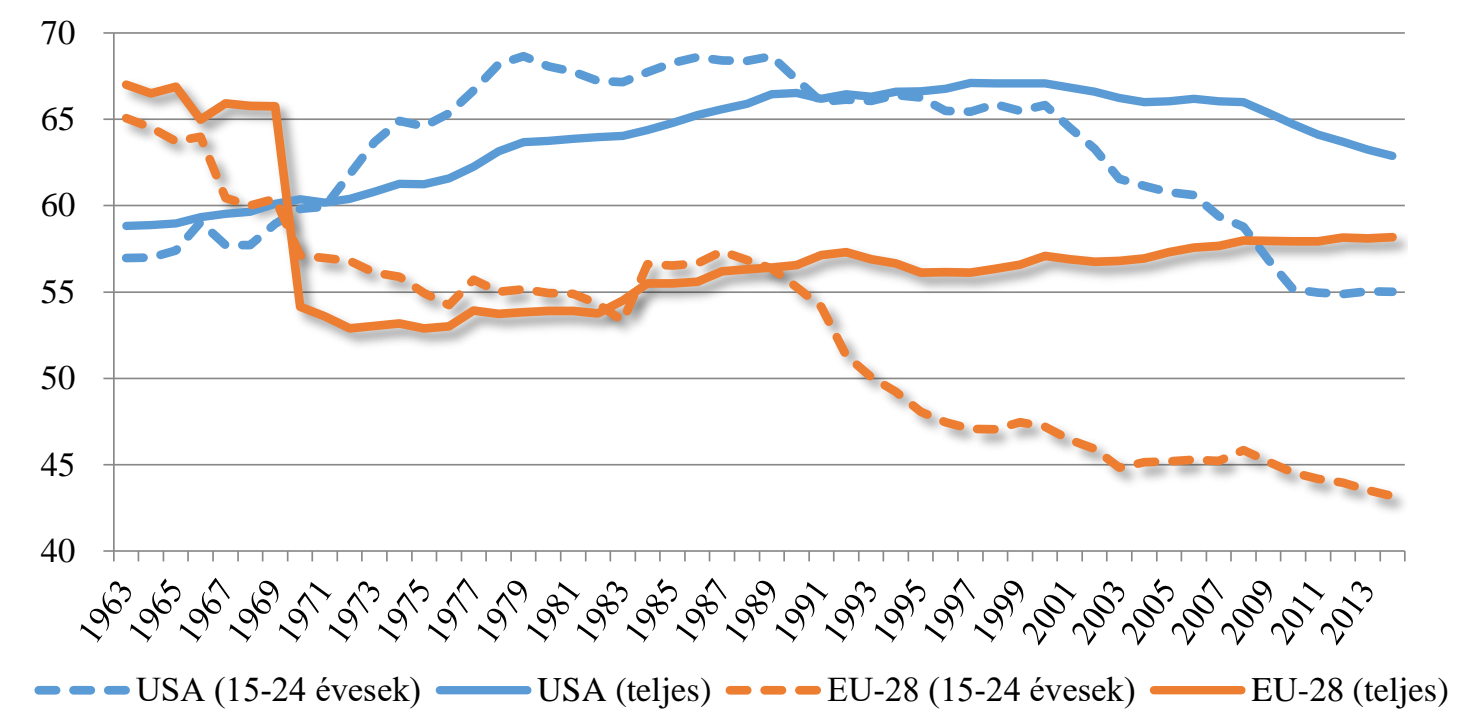

Forrás: OECD.Stat (2016) adatai alapján saját szerkesztés.

A 4.3. ábra azt is megmutatja, hogy az Európai Unióban a fiatalok aktivitási aránya az 1990-es években jelentősen elszakadt a teljes népességétől - erőteljesebben, mint az Egyesült Államokban, ahol ez csak az ezredforduló környékén jelentkezett. Ennek hátterében az a tendencia állhat, hogy az európai fiatalok egyre jelentősebb része vesz részt a felsőoktatásban, illetve szerez legalább középfokú végzettséget - az oktatásban való részvétel növekedésével pedig növekszik az inaktívak aránya a munkaképes korú népességen belül. A 4.2. táblázat jól mutatja, hogy a legalább középfokú végzettségűek aránya az elmúlt évtizedekben jelentősen emelkedett. Ez egyrészt a 2002-es és a 2016-os adatok összevetéséből látható, másrészt abból, hogy az idősebb korcsoportokban jóval alacsonyabb a képzettek aránya, mint a fiatalabbak között. Az Egyesült Államokban a legalább középfokú és a felsőfokú végzettségűek aránya legalább akkora, mint az Európai Unióban. (Az, hogy az idősebb korcsoportokat nézve jelentősen magasabb Egyesült Államokban a legalább középfokú és a felsőfokú végzettségűek aránya, egyrészt azt mutatja, hogy itt már korábban is nagyobb mértékben jellemző volt, hogy a fiatalok továbbtanultak, másrészt azt, hogy a gazdaságilag aktív felnőttek nagyobb része kapcsolódik be valamilyen képzésbe és oktatásba, mint az Európai Unióban.) 
4.2. táblázat A legalább középfokú és a felsőfokú ${ }^{36}$ végzettségüek aránya az EU-ban és az USA-ban (\%)

\begin{tabular}{lcc|cc|cc|cc}
\hline & \multicolumn{3}{c|}{\begin{tabular}{c} 
Legalább középfokú végzettségüek \\
\multicolumn{2}{c}{ aránya }
\end{tabular}} & \multicolumn{2}{c}{ Felsőfokú végzettségüek aránya } \\
\cline { 2 - 10 } & \multicolumn{2}{c}{ EU 28 } & \multicolumn{2}{c}{ USA } & \multicolumn{2}{c}{ EU 28 } & \multicolumn{2}{c}{ USA } \\
\cline { 2 - 10 } & $\mathbf{2 0 0 2}$ & $\mathbf{2 0 1 6}$ & $\mathbf{2 0 0 2}$ & $\mathbf{2 0 1 6}$ & $\mathbf{2 0 0 2}$ & $\mathbf{2 0 1 6}$ & $\mathbf{2 0 0 2}$ & $\mathbf{2 0 1 6}$ \\
\hline $\mathbf{2 0 - 2 4}$ évesek & 76,8 & 83,2 & 84,5 & $82,5^{*}$ & 11,4 & 17,6 & 16,8 & 16,7 \\
\hline $\mathbf{2 5 - 3 4}$ évesek & 75,6 & 83,5 & 86,9 & 91,5 & 24,4 & 38,2 & 39,3 & 47,5 \\
\hline $\mathbf{3 5 - 4 4}$ évesek & 70,1 & 80,5 & 88,4 & 89,5 & 21,1 & 35,5 & 38,6 & 48,4 \\
\hline $\mathbf{4 5 - 5 4}$ évesek & 63,1 & 75,2 & 89,1 & 89,4 & 18,6 & 27,1 & 39,7 & 44,9 \\
\hline $\mathbf{5 5 - 6 4}$ évesek & 50,3 & 68,8 & 83,6 & 90,2 & 14,5 & 22,3 & 33,2 & 41,9 \\
\hline $\mathbf{1 5 - 6 4}$ évesek & 63,0 & 73,5 & 80,2 & $89,0^{*}$ & 17,4 & 27,2 & 31,9 & 41,3 \\
\hline
\end{tabular}

Megjegyzés: 2016-ban az Egyesült Államok esetében a 20-24 évesek helyett a 18-24 évesekre, a 15-64 évesek helyett a 18-64 évesekre vonatkoznak az adatok.

Forrás: Eurostat (2017) és U.S. Census Bureau $(2002,2016)$ adatai alapján saját szerkesztés.

A 2007-2008-as recesszió következtében az Egyesült Államokban hamarabb, már 2007 nyarán emelkedni kezdett a munkanélküliségi ráta értéke, és több, mint kétszeresére nőtt: 2009 októberében tetőzött 10,0 százalékos szinten (Casaux-Turrini, 2011; Eurostat, 2017). Ezt követően viszont folyamatosan csökken, szemben az EU-ban 2013 közepéig tapasztalható növekedéssel (4.4. ábra). Ugyanez az időbeli elcsúszás figyelhető meg a 25 év alatti korosztályban is. Az Európát 2008-ban elérő válság hatására jelentősen megnövekedett a munkanélküliség: az Eurostat (2017) szezonálisan kiigazított adatai szerint 2007 3. negyedévében valamivel kevesebb, mint 16,5 millió munkanélkülit regisztráltak az EU 28 országában, 2014 azonos időszakában pedig már csaknem 24,5 milliót. A 25 év alatti korosztályban ezek az értékek rendre 4,2 millió és 5,1 millió körül alakultak. Maga a két időpont közötti változás a fiatalok szempontjából nem olyan kedvezőtlen, mint az idősebb korosztály számára: míg a 25-74 év közötti munkanélküliek száma az öt év alatt 53 százalékkal növekedett, addig a 25 év alattiak száma „csupán” 21 százalékkal.

A 2007-2008-as válság az európai országok munkapiacait is eltérően érintette. Az Eurostat (2016) adatai jól mutatják, hogy a válság előtti években jól teljesítő tagállamok némelyikében jelentősen megemelkedett a munkanélküliség (például a balti államokban, Cipruson, Írországban, Olaszországban), míg a korábban az átlag feletti munkanélküliségi rátával rendelkező Németország egyedülálló módon abszolút értelemben is jelentősen javított a helyzetén: a 2007-es 8,5 százalékról 2013-ban 5,2 százalékra csökkent a munkanélküliségi ráta. Voltak olyan országok is, ahol nem volt látványos a munkanélküliség növekedése: 2007ről 2013-ra nem haladta meg a két százalékpontot a ráta változása Luxemburgban, Ausztriában,

\footnotetext{
${ }^{36}$ Az ISCED11 (az oktatás nemzetközi osztályozási rendszere) 3-8 szintje jelöli a legalább középfokú végzettséget, és az 5-8 szintje a felsőfokúnak számító végzettségeket.
} 
Csehországban, Svédországban, Romániában, Máltán, (itt 6,5 százalékról 6,4 százalékra csökkent is), Finnországban, Belgiumban és Lengyelországban. A mediterrán országokat a válság óta sújtó rendkívül magas munkanélküliség pedig a médiából is jól ismert.

4.4. ábra Munkanélküliségi ráta az Európai Unió 28 országában és az Egyesült Államokban (2007.01-2017.04.; szezonálisan kiigazított adatok; \%)

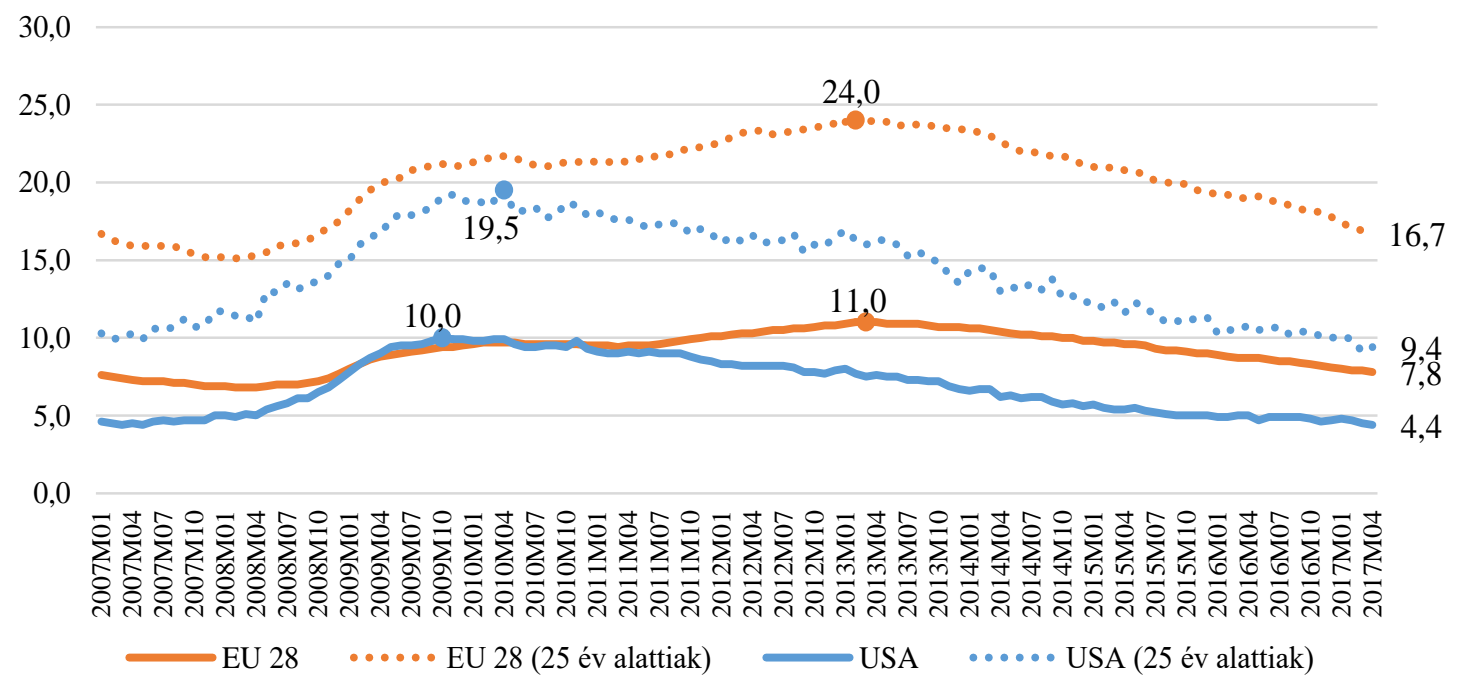

Forrás: Eurostat (2017) adatai alapján saját szerkesztés.

A munkanélküliségi ráták alapján a következő megállapításokat tehetjük az EU 28 országára: 2007-ről 2013-ra a teljes népességre vetített munkanélküliségi ráta 7,1 százalékról 10,7 százalékra növekedett; ezen belül a 25-74 éveseké 6,1 százalékról 9,5 százalékra, a 25 év alattiaké pedig 15,5 százalékról 23,5 százalékra (OECD.Stat, 2016). (2014-re már enyhe javulás figyelhető meg.) Ez alapján azt mondhatjuk, hogy a fiatalokat rendkívül súlyosan érintette a válság. A fiatal munkanélküliek számának kisebb mértékü emelkedése és a munkanélküliségi rátájuk jelentős megugrása közötti ellentmondás hátterében az aktív fiatal népesség csökkenése állhat: 2007-ben 26,9 millió 15-24 év közötti gazdaságilag aktív fiatalt regisztráltak, 2013-ban már csak 23,8 milliót. Tehát míg a fiatal munkanélküliek száma kb. 1,4 millióval növekedett a 6 év alatt, addig a - munkanélküliségi ráta nevezőjét képző - aktívak száma több, mint 3 millióval csökkent. A gazdaságilag aktív fiatalok számának csökkenése egyrészt a fiatal népesség jelentős arányú csökkenéséből, másrészt a korosztály aktivitási rátájának enyhe csökkenéséböl adódik.

A munkanélküliek teljes korcsoportos népességen belüli arányát vizsgálva a válság alatt információt kapunk az ifjúsági munkanélküliségi arány alakulásáról. E mutató esetében az ifjúsági munkanélküliségi rátához képest némileg más képet kapunk (4.3. táblázat): 2007-ben a 15-24 évesek 6,8 százaléka volt munkanélküli, 2013-ban már 9,6 százalékuk; míg 
ugyanezekben az években a 25-74 éves korosztály rendre 4,0 százaléka illetve 6,4 százaléka. A mutató a két korosztályra nézve tehát hasonló mértékủ százalékpontos növekedést produkált (a fiatalok között ez 2,8, a 25-74 évesekre 2,4). Ám az is igaz, hogy a vizsgált időszakban a korcsoportos népesség nem egyformán változott, hiszen a fiatalok száma évről évre csökkent, az idősebbeké viszont összességében növekedett.

4.3. táblázat A munkanélküliségi arány változása az EU 28 országában (1000fö)

\begin{tabular}{lccccccccc}
\hline & \multicolumn{3}{c}{$\begin{array}{c}\text { Népesség } \\
\text { (ezer fö) }\end{array}$} & & \multicolumn{2}{c}{$\begin{array}{c}\text { Munkanélküliek száma } \\
\text { (ezer fö) }\end{array}$} & \multicolumn{3}{c}{$\begin{array}{c}\text { Munkanélküliségi } \\
\text { arány (\%) }\end{array}$} \\
\cline { 2 - 10 } & 2007 & 2013 & $\begin{array}{c}\% \text { \%os } \\
\text { változás }\end{array}$ & 2007 & 2013 & $\begin{array}{c}\%-o s \\
\text { változás }\end{array}$ & 2007 & 2013 & $\begin{array}{c}\text { változás } \\
\text { (\%pont) }\end{array}$ \\
\hline $\begin{array}{l}\text { Teljes } \\
\text { népesség }\end{array}$ & 498409 & 506612 & $+1,6 \%$ & 16988 & 26292 & $+54,8 \%$ & 3,41 & 5,20 & $+1,79$ \\
\hline $\begin{array}{l}\mathbf{1 5 - 2 4} \\
\text { évesek }\end{array}$ & 62412 & 58286 & $-6,6 \%$ & 4242 & 5619 & $+32,5 \%$ & 6,80 & 9,64 & $+2,84$ \\
\hline $\begin{array}{l}\mathbf{2 5 - 7 4} \\
\text { évesek }\end{array}$ & 317933 & 325000 & $+2,2 \%$ & 12746 & 20673 & $+62,2 \%$ & 4,00 & 6,36 & $+2,36$ \\
\hline
\end{tabular}

Forrás: Eurostat (2016) adatai alapján saját szerkesztés.

A munkán és oktatáson kívüliek arányáról (NEET) elmondható, hogy míg 2007-ben az EU 28 országában a 15-24 éves népesség 11 százaléka tartozott ebbe a csoportba, 2013-ban már 13 százalékuk (Eurostat, 2017). Más szóval hat év alatt 6,8 millióról csaknem 7,5 millióra növekedett azon 15-24 éves fiatalok száma, akik nem voltak foglalkoztatottak és nem is tanultak.

Az Eurostat (2016) adatai szerint 2007-ben, azaz a válság előtt, a 15-24 éves munkanélküliek egynegyede (26,3\%) volt egy éven túl is munkanélküli, 2013-ra pedig egyharmadra (34,2\%) növekedett ez az arány. A 25 év felettiek esetében nem mutatkozik ilyen drasztikus romlás a válság következtében, viszont eleve sokkal magasabb volt az induló szint: 48,3 százalékról 51,0 százalékra növekedett. A 4.5. ábra megmutatja a munkanélküliség tartósságának eltérését az EU 28 országában és az USA-ban. Jól látható, hogy az EU-ban a válság előtt és után is minden korosztályra jellemző, hogy a munkanélküliek több mint fele legalább fél éven keresztül kénytelen új állást keresni. Ezzel szemben az Egyesült Államokban 2013-ban is az összes munkanélkülinek csak kevesebb, mint 40 százaléka, a 15-24 éveseknek pedig hozzávetőleg az egynegyede keresett 6 hónapnál hosszabb ideig állást. Ezt az eltérést a szakemberek többnyire az európai államokban jellemző bőkezű munkanélküli ellátásnak (a helyettesítési hatásnak) tudják be. 
4.5. ábra A munkanélküliség tartósság szerinti megoszlása az EU 28 országában és az USA-ban (2007 és 2013; \%)

Teljes népesség

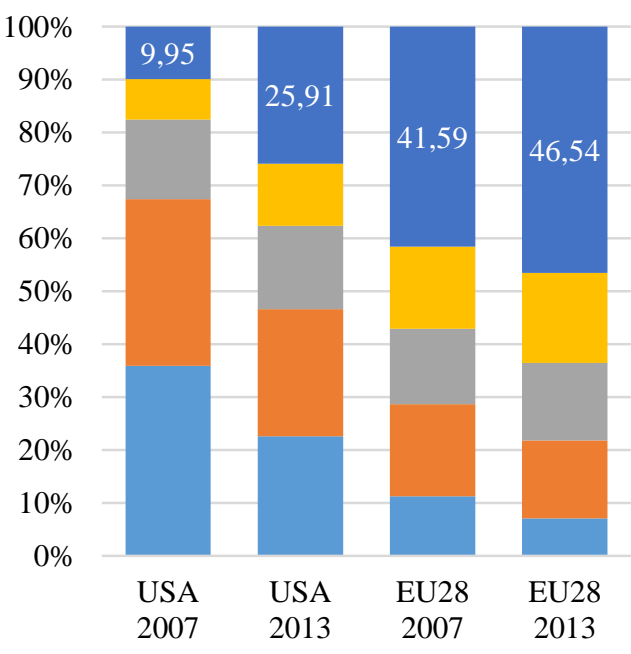

15-24 évesek

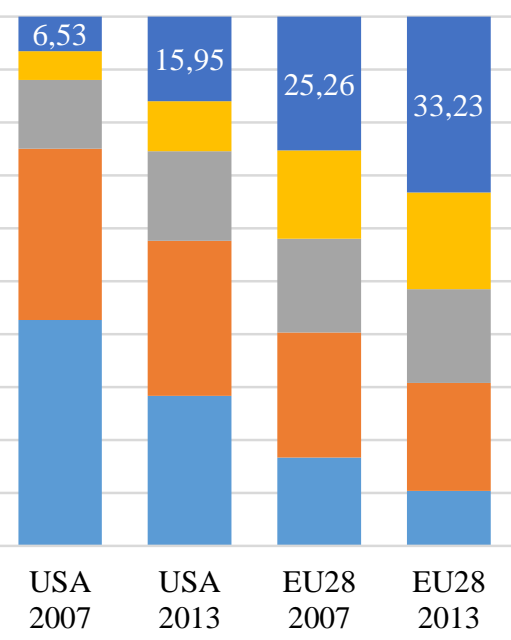

min. 1 év

6-12 hónap

3-6 hónap

1-3 hónap

max. 1 hónap

Forrás: OECD.Stat (2015) adatai alapján saját szerkesztés.

Mindkét térségben megfigyelhető továbbá, hogy a fiatal munkanélküliek között jelentősen kisebb a hosszú távú munkanélküliek aránya (4.5. ábra, 4.4. táblázat). Ennek egyik oka, hogy a fiatalok munkaerőpiaci kategóriák közötti mozgása jellemzően sokkal gyorsabban zajlik, mint az idősebbeké (OECD, 1983). Másrészt pedig a fiatal munkanélküliek jelentős része a munkaerőpiacon kívülről (az inaktív gazdasági státuszt jelentő iskolai éveit követően) lép be a munkanélküli státuszba - ellentétben a 25 év felettiekkel -, és ez gyakran csak egy rövidebb, átmeneti időszakot jelent az első állás betöltése előtt (ILO, 2016b).

4.4. táblázat A munkanélküliség időtartama az EU-ban és az USA-ban

\begin{tabular}{lccccc}
\hline & & \multicolumn{2}{c}{ EU 28 } & \multicolumn{2}{c}{ USA } \\
\cline { 2 - 6 } & & $\mathbf{2 0 0 8}$ & $\mathbf{2 0 1 3}$ & $\mathbf{2 0 0 8}$ & $\mathbf{2 0 1 3}$ \\
\hline \multirow{2}{*}{ Munkanélküliségi ráta (\%) } & teljes népesség & 7,0 & 10,9 & 5,8 & 7,4 \\
\cline { 2 - 6 } & $15-24$ évesek & 15,7 & 23,8 & 12,8 & 15,5 \\
\hline Hosszú távú (min. 1 év) & teljes népesség & 2,6 & 5,1 & 0,6 & 1,9 \\
\cline { 2 - 6 } munkanélküliségi ráta (\%) & $15-24$ évesek & 3,5 & 8,0 & n.a. & n.a. \\
\hline Legalább 12 hónapja & teljes népesség & 37,3 & 47,3 & 10,6 & 25,9 \\
\cline { 2 - 6 } munkanélküliek az összes & $15-24$ évesek & 22,2 & 33,2 & 7,1 & 15,9 \\
\hline munkanélküli \%-ában & teljes népesség & 13,9 & 13,3 & 4,1 & 8,4 \\
\hline Munkanélküliség átlagos & $15-24$ évesek & 8,1 & 9,5 & 3,2 & 5,5 \\
\hline idötartama (hónap)
\end{tabular}

Forrás: Eurostat (2016) és OECD.Stat (2016) adatai alapján saját szerkesztés.

A válság legmélyebb pontja óta lassú javulás figyelhető meg a munkaerőpiaci adatok alakulásában. A 4.6. ábra azt szemlélteti, hogy az Európai Unióban a fiatal és az idősebb munkanélküliek száma egyaránt folyamatosan csökken 2013 eleje óta, de még mindig 
magasabb, mint a válságot megelőző időszakban volt, így a probléma korántsem tekinthető megoldottnak.

4.6. ábra Munkanélküliek száma az EU 28 országában (2007.I.né.-2017.I.né.; szezonálisan kiigazított adatok; 1000 fö)

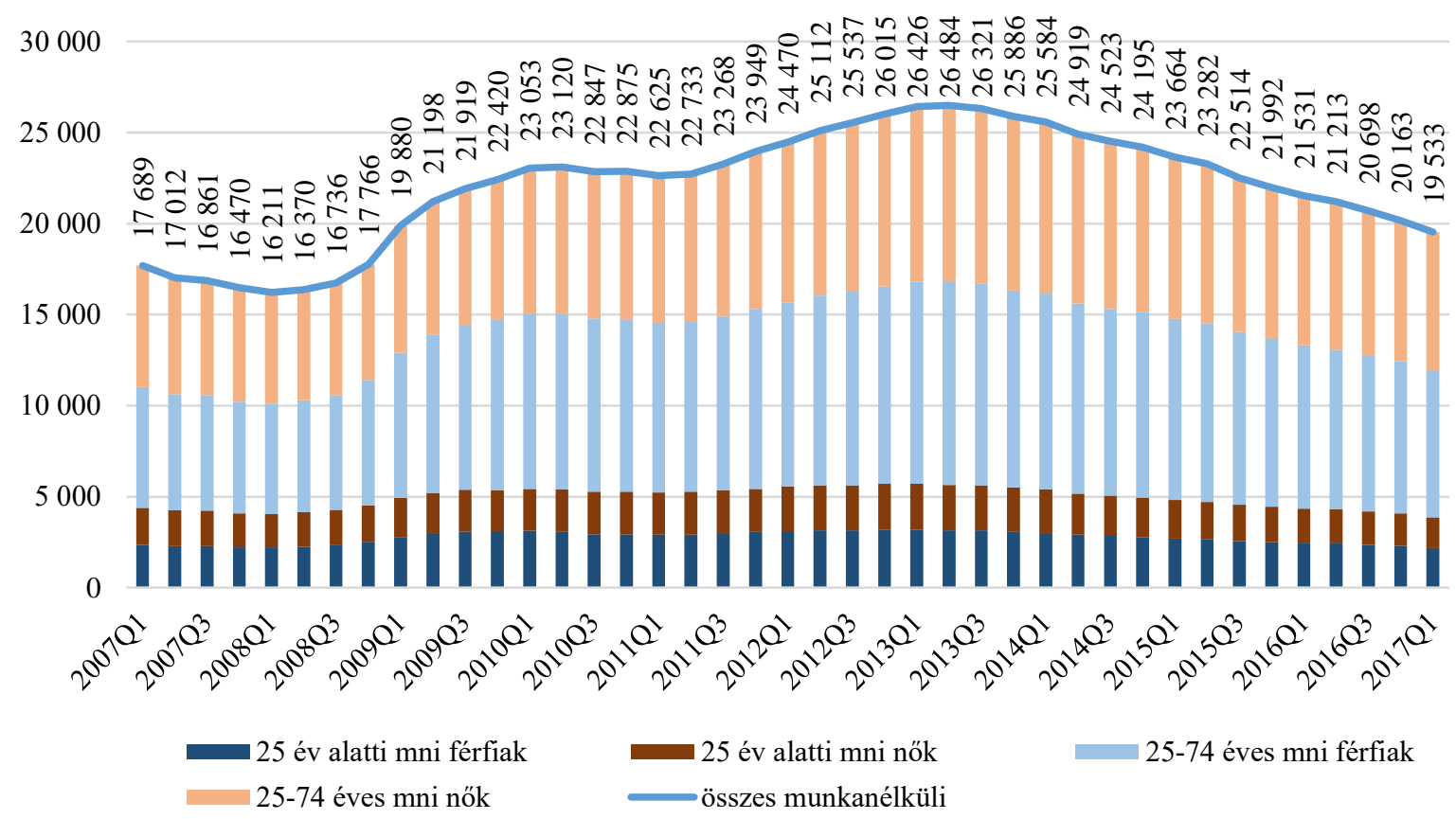

Forrás: Eurostat (2017) adatai alapján saját szerkesztés.

A 4.7. ábra azt is megmutatja, hogy a férfiak munkanélkülieken belüli aránya a válság évei alatt megugrott - mind a fiatalabb korosztályt, mind a teljes népességet tekintve. Ez egyébként nem szokatlan recesszió idején, hiszen a visszaesésre érzékenyen reagáló ágazatokban - tipikusan ilyen az építőipar - túlsúlyban van a férfi munkaerő (Arpaia-Curci, 2010).

4.7. ábra A férfiak munkanélkülieken belüli aránya az Európai Unió 28 országában (2006-2016)

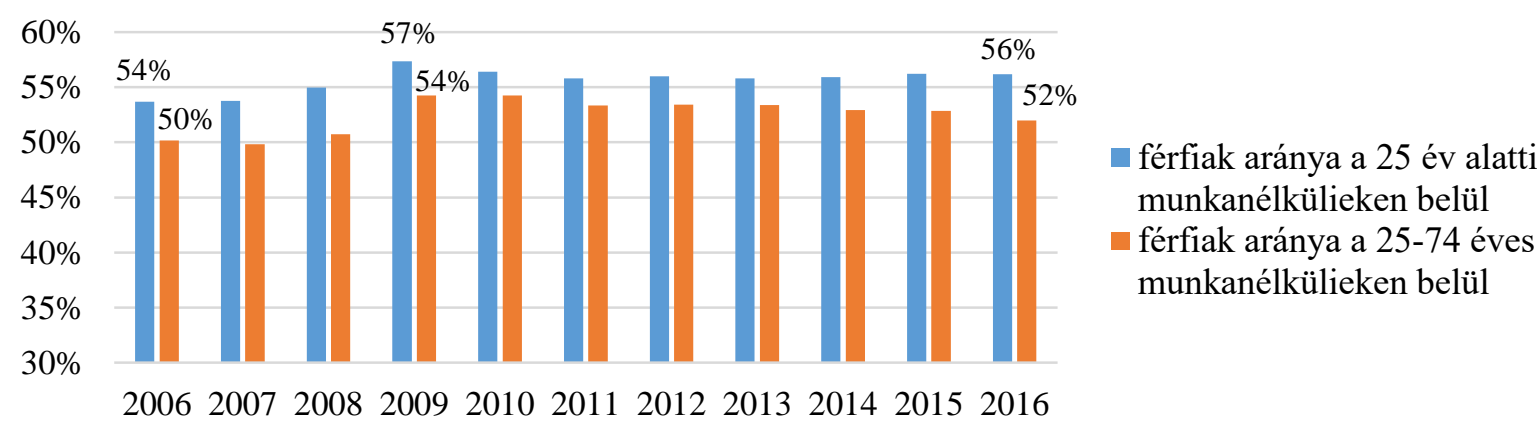

Forrás: Eurostat (2017) adatai alapján saját szerkesztés.

Köztudott, hogy a 2008-as válság még erőteljesebben felhívta a figyelmet a fiatalok közötti magas munkanélküliség korábban is létező problémájára. Különösen a mediterrán 
országokat (Görögország, Spanyolország, Olaszország, Portugália) szokták nevesíteni. Témaválasztásunk is igazolja, hogy fontosnak tartjuk az ifjúsági munkanélküliség kérdését, de amint arra már korábban is utaltunk, e promléma nem határolható le a teljes munkanélküliségtől, nem kezelhető a munkaerőpiac általános feltételeinek javítása nélkül. Jól alátámasztja ezt Artner (2013) elemzése és a 4.8. ábra. Ez megmutatja, hogy összességében az Európai Unió 28 tagállamában a fiatalok munkanélkülieken belüli aránya 2008 óta folyamatosan csökken, elmaradva a fiatalok teljes népességen belüli arányának csökkenésétől, mindez pedig az ifjúsági munkanélküliség relatív súlyának csökkenését hozza magával. Országonként természetesen lehet eltérés ettől az átlagtól, és Artner (2013, 1378. o.) is megjegyzi, hogy „a fiatalok munkanélküliségének relativ jelentösége elsősorban az EU fejlettebb országaiban nött”. Ezzel együtt nem lehet kérdés, hogy érdemes a fiatalok munkaerőpiaci helyzetével külön is foglalkozni - itt csupán arra igyekeztünk felhívni a figyelmet, hogy a fiatalok helyzete nem annyival rosszabb, mint amit a magasabb munkanélküliségi rátájuk első ránézésre sugall.

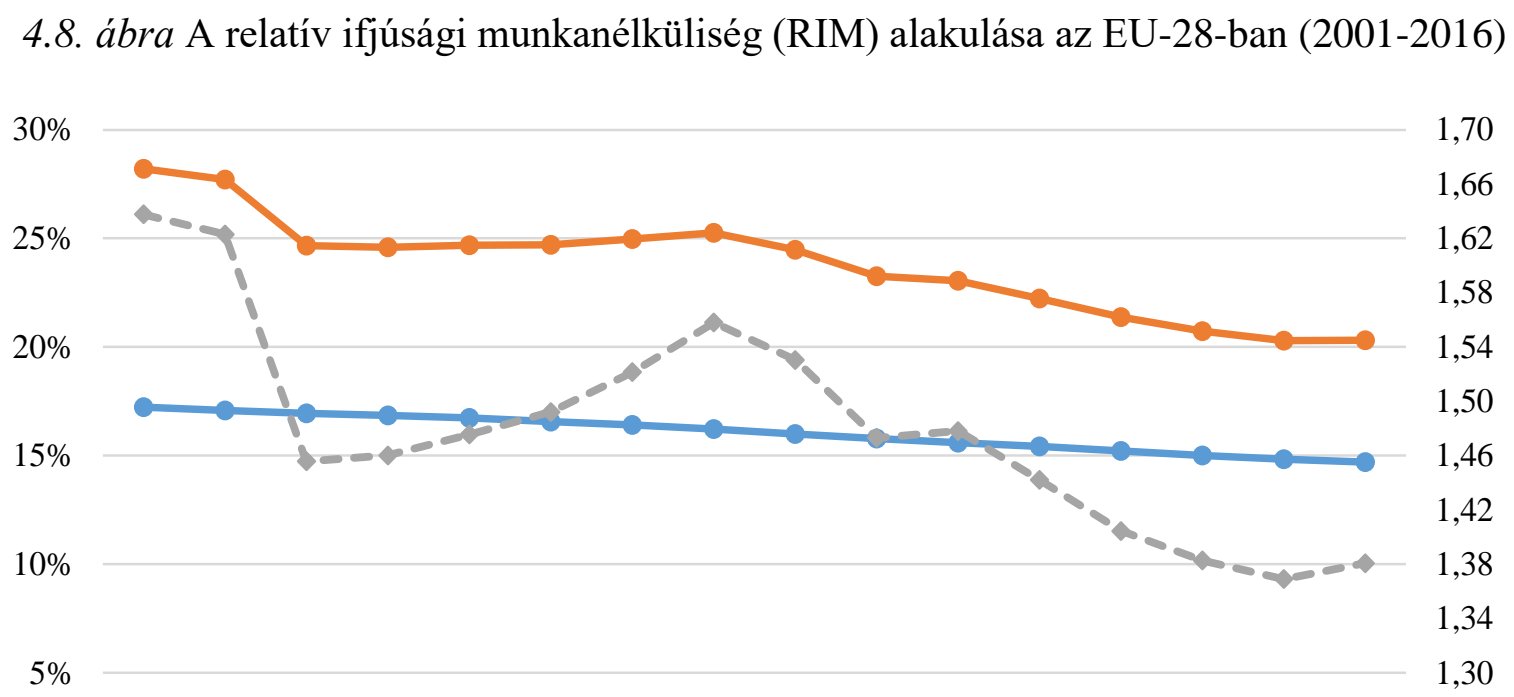

2001200220032004200520062007200820092010201120122013201420152016

- 15-24 éves népesség aránya a 15-74 éves népességben (bal tengely)

- Fiatalok aránya a munkanélküliek között (bal tengely)

$\rightarrow-$ Relatív ifjúsági munkanélküliség (RIM) (jobb tengely)

Forrás: Eurostat (2017) adatai alapján saját szerkesztés.

A válság során az Európai Unió tagállamainak munkanélküliségi rátáiban nagyobb lett a szórás mind a teljes népességet, mind a fiatal korosztályt tekintve. Az ifjúsági munkanélküliség tagországok közötti különbözőségeit mutatja a 4.9. ábra. Az ábra adatai alapján is egyértelmüen kirajzolódik az, amire már korábban is felhívtuk a figyelmet: az ifjúsági munkanélküliségi ráták minden országban meghaladják a teljes népességre vonatkozó munkanélküliségi rátákat. 
Ugyanakkor az is látható, hogy számos EU-tagországban 20 százalék felett volt az ifjúsági munkanélküliségi ráta 2013-ban, míg az USA-ban ez az érték 15,5 százalék volt. A tagországok közötti, viszonylag jelentősnek mondható szóródás is felveti a kérdést, hogy ebben a folyamatban a munkaerőpiac rugalmasságának és egyéb jellemzőinek milyen szerepe lehet.

4.9. ábra Munkanélküliségi ráták az EU 28 országában és az USA-ban 2013-ban (\%)

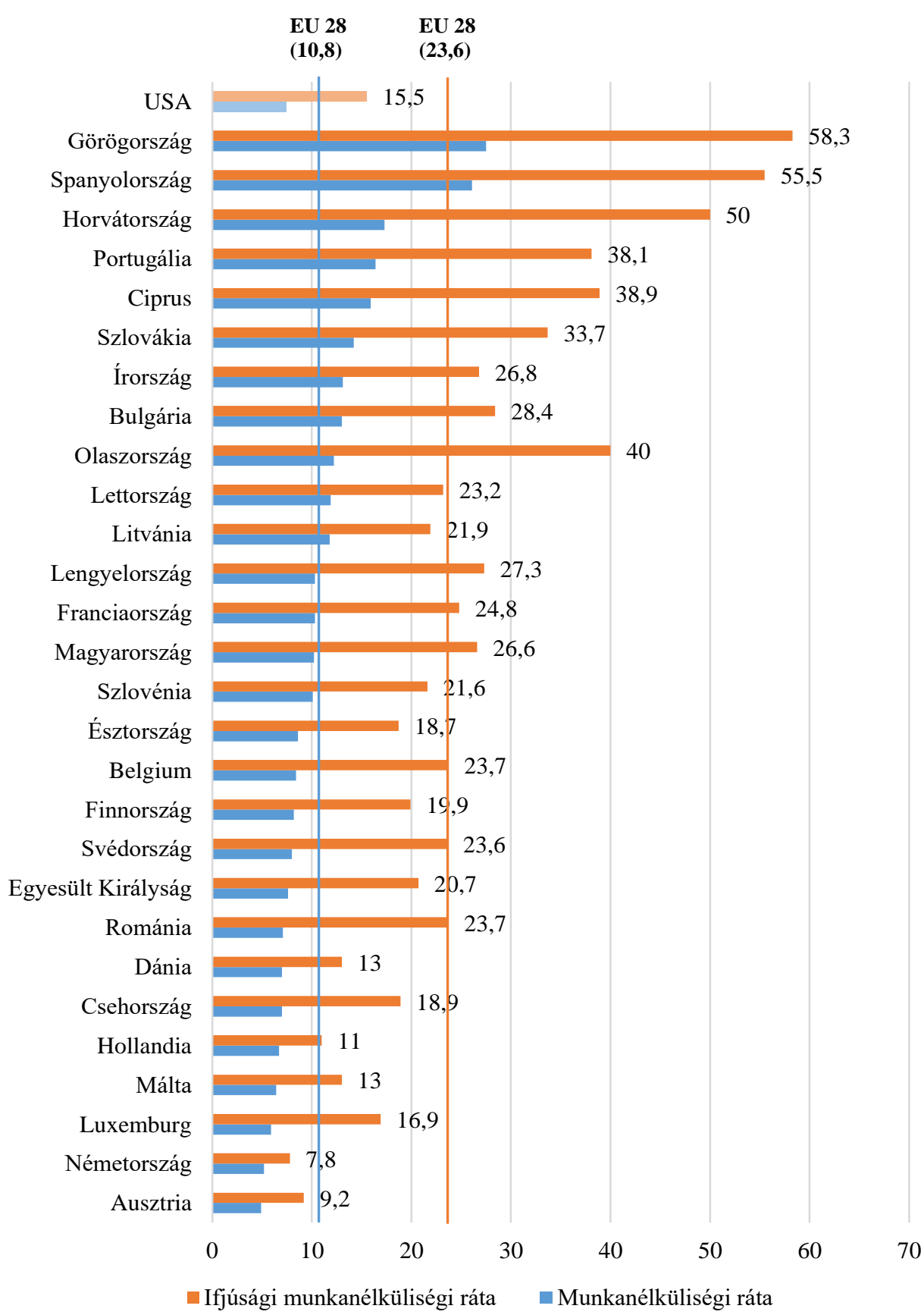

Forrás: Eurostat (2016) adatai alapján saját szerkesztés.

A továbbiakban ismertetjük az ifjúsági munkanélküliség hatásait magukra a munkanélküli fiatalokra, valamint az adott ország teljes társadalmára és gazdaságára. 
A hosszú távú ifjúsági munkanélküliség következményei - hasonlóan az általában vett munkanélküliségéhez - sokrétűek lehetnek. A jövedelem-kiesés következtében fellépő anyagi nehézségek, valamint a munka által meghatározott társadalmi státusz és identitás elvesztése következtében megjelenő élettani és pszichológiai sérülések súlyossága gyorsan növekszik a munkanélküliség hosszával párhuzamosan (CDPS, 2001; O’Higgins, 1997). A fiatalon megtapasztalt munkanélküliség tartós hatással lehet a későbbi termelékenységre és így a foglalkoztatási és kereseti kilátásokra. A nagymértékü ifjúsági munkanélküliség magában hordozza egy elveszett generáció (lost generation) kialakulásának veszélyét, amelynek tagjai a fiatal kori munkanélküliség következtében későbbi életük során is kedvezőtlen foglalkoztatási kilátásokkal rendelkeznek (ezt sebhely-hatásnak [scarring effect] is nevezik) (Eurofound, 2012a; Scarpetta et al., 2010). ${ }^{37}$ Ez a hosszú távú következmény az egyik fö különbség az idősebb és a fiatal korban jelentkező munkanélküliség között. Összességében akárcsak magának a munkanélküliségnek, a fiatalok munkanélküliségének is vannak gazdasági, társadalmi és az egyén szintjén értelmezhető (pszichés) hatásai, amelyeket a 4.10. ábra szemléltet.

4.10. ábra Az ifjúsági munkanélküliség egyéni és társadalmi következményei

\begin{tabular}{|l|}
\hline \multicolumn{1}{|c|}{ Individuális következmények } \\
\hline - anyagi nehézségek \\
- pszichológiai problémák \\
- egészségügyi problémák \\
$\downarrow$ \\
- humán tőke leépülése \\
- bizonytalan vagy alulfizetett \\
foglalkoztatás \\
- elszigetelödés \\
- önpusztító életformák \\
- családi problémák
\end{tabular}

\begin{tabular}{|l|l|}
\hline \multicolumn{1}{|c|}{ Társadalmi hatások } \\
\hline & - leterhelt egészségügy \\
- & bünözés \\
- & társadalmi kohézió gyengülése \\
\cline { 2 - 3 } &
\end{tabular}

$y$

\begin{tabular}{|c|}
\hline Gazdasági hatások \\
\hline- ténylegesen felmerülö költségek \\
- haszonáldozati költségek
\end{tabular}

Forrás: saját szerkesztés.

37 Egyes kutatások szerint a munkanélküliség későbbi előfordulása azonban nem a korábbi munkanélküliség következménye, hanem ugyanazokra, már a pályakezdés előtt is meglévő egyéni jellemzőkre (hátrányos társadalmi és/vagy munkaerőpiaci helyzetre) vezethető vissza, amelyek magát a fiatal kori munkanélküliséget okozták (CDPS, 2001). Úgy véljük, hogy mindkét megközelítés elfogadható lehet: a sebhelyhatás alapvetően a kezdeti hátrányos helyzet következményeként jelentkezik, amelyet tovább súlyosbíthat a fiatalon megtapasztalt (hosszabb távú) munkanélküliség során bekövetkező humán tőke leépülés. 


\subsubsection{INDIVIDUÁLIS ÉS TÁRSADALMI HATÁSOK}

A munkanélküliség individuális következményei hosszú távon kihathatnak az egyénre, főként, ha időben elhúzódik a munkanélküli (vagy NEET) állapot. Ezeket alapvetően két nagyobb kategóriába sorolhatjuk be: az anyagi és a pszichológiai (egészségi) problémák közé. Lorenzini és Giugni (2010) tanulmányukban azzal a kérdéssel foglalkoznak, hogy a fiatalok számára ezeket a nehézségeket hogyan könnyítheti meg a partner, a család és a közeli barátok (anyagi, érzelmi és erkölcsi) támogatása. Az eredményeik vegyesnek mondhatóak, mégis összességében azt a következtetést vonják le, hogy ez a „szociális védőháló” valóban segíthet mentálisan és anyagilag is, de mindez nem egyértelmü és természetesen nem is jelent „végleges” megoldást a problémára, csupán átmeneti segítséget.

A munkanélküliség idősebb és fiatalabb korban is hasonló következményekkel jár az egyén számára, mégis vannak olyan különbségek, melyeket érdemes szem előtt tartani. A fiatalok számára a (hosszabb ideig tartó) munkanélküliségnek a következő hatásait szokás kiemelni (Artner, 2013; CDPS, 2001; Eurofound, 2012a; Lorenzini-Giugni, 2010; Wilpert, 2009):

- alacsony életszínvonal, anyagi nehézségek;

- pszichológiai és mentális problémák: szorongás, magányosság, nyugtalanság, erőtlenség, kimerültség, depresszió - ezek következményeként az általános pszichológiai értelemben vett jól-lét veszélybe kerül;

- megromlott egészségi állapot: ez egyrészt a rossz lelkiállapot következményeként is kialakulhat, másrészt az anyagi nélkülözés miatt is;

- elszigetelődés, az emberi kapcsolatok leépülése, stressz;

- alkoholizmus, kábítószer-használat, bünözés és más önpusztító életformák kialakulása;

- a felhalmozott tudás elévülése, a humán tőke leépülése;

- bizonytalan foglalkoztatás a későbbiekben;

- alulfizetett foglalkoztatás: ez tulajdonképpen azt jelenti, hogy a fiatal szorult helyzetében olyan munkát is elfogad, amelynél kvalitásai alapján többre hivatott hosszabb távon az ilyen jellegü munkavégzés is elégedetlenséget, lelki problémákat szülhet.

Ezek a hatások mind befolyásolhatják a munkanélküli fiatalok későbbi foglalkoztatási kilátásait. A sebhely-hatás elemzésével számos vizsgálat foglalkozik. Mroz és Savage (2006) az ifjúsági munkanélküliség hosszú távú hatásait vizsgáló tanulmányukban amerikai (USA) 
adatokat felhasználva empirikusan bizonyították, hogy azoknak a munkavállalóknak, akik fiatal korukban megtapasztalták a munkanélküliséget, még csaknem 10 évvel később is 2-3 százalékkal alacsonyabb volt a bérük, mint azoknak, akik nem voltak fiatalon munkanélküliek. Ez az eredmény jól alátámasztja, hogy időben milyen rendkívül elhúzódó hatásai vannak a fiatalok számára, ha nem találnak megfelelő állást. Emellett a szerzők azt is megállapították, hogy amennyiben valaki később is munkanélkülivé válik, akkor a korábbi munkanélküliség következtében az aktuális munkanélküliség hosszabb ideig tart. Kawaguchi és Murao (2014) 20 OECD országra az 1960-2010-es időszakra elvégzett panelvizsgálata pedig megerősítette, hogy ahol a fiatalok körében magas volt az ifjúsági munkanélküliség, ott később, mikor a munkavállalók már idősebbek lettek, a munkanélküliségi ráta szintén magasabb volt - különösen azokban az országokban, amelyeket merev munkaeröpiaci intézmények jellemeznek. Gregg (2001) az Egyesült Királyságban folytatott vizsgálatának eredménye hasonlóképpen az lett, hogy azok a férfiak, akik fiatalon voltak munkanélküliek, később is nagyobb valószínüséggel lettek azok: 23 éves kor alatt minden többlet három hónapnyi munkanélküliség újabb 2 hónap munkanélküliséget (vagy inaktivitást) eredményezett 28-33 éves kor között. (A nők esetében nem mutatkozott ilyen egyértelmü összefüggés). A szerző megjegyzi, hogy ezt a kapcsolatot az alacsony iskolai végzettség, a gyenge helyi munkaerőpiac, a kedvezőtlen családi háttér és az egyéni képességek összességében kevesebb, mint fele részben magyarázzák, tehát akik fiatalon voltak munkanélküliek, azok ezektől a tényezőktől függetlenül későbbi életük során is nagyobb eséllyel számolhatnak a munkanélküliség kockázatával. Ebből leszürhető az a tanulság, hogy (függetlenül a kezdeti hátrányos feltételektől és jellemzőktől) a fiatalok munkanélküliségének kezelése hosszú távú pozitív hatásokkal jár, amennyiben az javítja a foglalkoztathatóságukat.

Az ifjúsági munkanélküliség társadalmi következményei az individuális hatásokból levezethetők (4.10. ábra). Ilyen a leterhelt egészségügy és jóléti rendszerek; a bűnözés, ehhez kapcsolódóan a zsúfolt börtönök; a családi problémák (CDPS, 2001; Eurofound, 2012a). Emellett a demokratikus elkötelezettség és a társadalmi részvétel hiánya következtében alacsonyabb a részvétel a választásokon és gyengül a civil társadalom is. Az európai fiatalok esetében ez nemzeti és uniós szinten egyaránt értelmezhető (Bălan-Bălan, 2012; GiugniLorenzini, 2012). Más szempontból viszont az elégedetlen fiatalokat könnyebb mozgósítani a társadalmi elégedetlenség kifejezése érdekében (pl. tüntetéseken), ami a politikai stabilitást 
gyengítheti. ${ }^{38}$ Fontos következmény továbbá, hogy a munkanélküliek és a munkavállalók közötti szakadék veszélyezteti a társadalmi kohéziót (CDPS, 2001).

\subsubsection{GAZDASÁGI HATÁSOK}

Az ifjúsági munkanélküliség és a NEET jelenség gazdasági kihatásait több tanulmányban is megkísérelték számszerüsíteni. Az Eurofound (2012a) 153 milliárd euróra becsülte 2011-ben a NEET fiatalok éves költségét uniós szinten - ez az EU GDP-jének 1,21 százalékának felelt meg (lásd még Coles et al., 2010). Ezek a költségek alapvetően két kategóriába sorolhatóak:

- a ténylegesen felmerülö költségek: ilyenek az államháztartási költségek, például munkanélküli ellátás, különböző támogatások az álláskeresők számára, aktív munkaerőpiaci politikai kiadások;

- és az ún. haszonáldozati költségek (vagy erőforrásköltségek): a kieső termelés és a kieső (közvetlen és közvetett, az alacsonyabb fogyasztásból adódóan elmaradó) adók, járulékok tartoznak ide, amiket nehéz megbecsülni, de nagyon is jelentősek.

A fejlett gazdaságokban, jóléti államokban a fiatalok vállára nehezedik az idősebb generációkról való gondoskodás terhe is. Az Európai Unió számára komoly kihívást jelent az idősödés. A felosztó-kirovó nyugdíjrendszereket alkalmazó államokban a jelenség önmagában is súlyos terhet ró az államháztartásra a fiatalok csökkenő népességen belüli aránya következtében, de ha belegondolunk, hogy milyen jelentős az a kieső járulékösszeg, amelyet az állástalan fiatalok nem fizetnek meg, akkor még inkább kérdésessé válik a jóléti államokban az időskori járadékfizetés - és általában a szociális juttatások - fenntarthatósága (Sarfati, 2013).

Ezek alapján kijelenthető, hogy a hosszú távon is nagymértékben fennmaradó ifjúsági munkanélküliség makrogazdasági problémákat és politikai kihívásokat eredményezhet, így e jelenség megértése és kezelése mindenképpen fontos, hogy kiemelt gazdaságpolitikai cél legyen - természetesen nem lehatárolva a teljes munkanélküliségtől. (Az e célt szolgáló lehetséges eszközökkel bővebben az 5. fejezetben foglalkozunk.) A következökben áttekintjük az ifjúsági munkanélküliség kialakulásának és tartós fennmaradásának okait A 2. fejezetben már foglalkoztunk a munkanélküliség általános megközelítésével, ezért itt igyekszünk csupán

38 A fejlődő országokban előfordulhat, hogy polgárháborúkban használják a munkanélküli fiatalokat példa erre Sierra Leone esete (Hilson-Osei, 2014). Továbbá egy 24 fejlődő államra az 1980-2010-es időszakra kiterjedő vizsgálattal megállapítást nyert, hogy a magas fiatalkori munkanélküliség és a politikai instabilitás között szignifikáns kapcsolat áll fenn, valamint a kiemelkedően magas ifjúsági munkanélküliségi ráta, a társadalmi-gazdasági egyenlőtlenségek és a korrupció együttesen magasabb politikai instabilitáshoz és a nemzeti biztonság hiányához vezetnek (Azeng-Yogo, 2013). Azaz nem csak a politikai instabilitás befolyásolja a fiatalok munkavállalási lehetőségeit, hanem a fiatalok rossz elhelyezkedési lehetőségei tovább mélyítik a politikai bizonytalanságot. 
azokra a kérdésekre fókuszálni, amelyek kifejezetten a fiatal korosztályt érintik. Legkésőbb az oktatási rendszerből kikerülve a fiatalok szembesülnek az álláskeresés nehézségeivel. Az ő helyzetük ilyenkor több szempontból is nehezített az idősebb álláskeresőkéhez képest, ráadásul sokszor a már megszerzett munkát is könnyebben veszíthetik el. Mindez több okra vezethető vissza: intézményi, strukturális és individuális jellemzők is hozzájárulnak ahhoz, hogy egy fiatalból NEET váljék.

\subsection{AZ IFJÚSÁGI MUNKANÉLKÜLISÉG OKAI}

Ebben az alfejezetben áttekintjük azokat a személyes, strukturális és intézményi tényezőket, amelyeket a szakirodalom a fiatalok munkanélküliségéhez vezető okokként említ (4.11. ábra). Mivel a dolgozat fókuszában az Európai Unió áll, ezért elsősorban a fejlett - európai országokra jellemző vonásokra koncentrálunk, de az ifjúsági munkanélküliség általános megítéléséhez szükségesnek tartjuk, hogy megemlítsünk néhány olyan problémát is, amelyek tipikusan a fejlődő országokban fordulnak elő.

Az ifjúsági munkanélküliség okainak feltárására és összegzésére több átfogó tanulmány is készült. Ezek alapján megállapítható, hogy az okok nagyban megegyeznek az általános munkanélküliséghez vezető tényezőkkel (kifejezetten ilyenek az egyéni jellemzők, például az alacsony iskolázottság; rossz egészségi állapot; de a bevándorlók vagy elmaradott térségben élő munkavállalók is jellemzően nehezebben találnak állást), ám vannak tipikusan a fiatalokat érintő faktorok is. A szakirodalom ide sorolja az iskolából a munkába való átállás nehézségeivel kapcsolatos strukturális és intézményi tényezőket (Dietrich, 2012).

\subsection{1. ábra Az ifjúsági munkanélküliség okai}

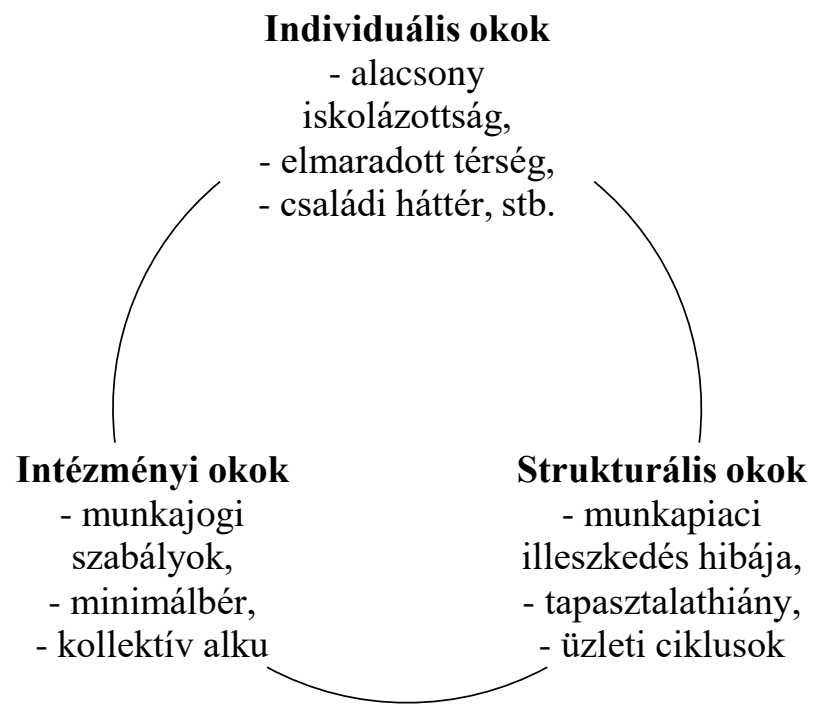

Forrás: saját szerkesztés. 
A mikro szintü, individuális tényezőket figyelembe véve az egyéni képességek és a lelki alkat értelemszerüen meghatározó, de fontosak más, objektíven mérhető és megítélhető szempontok is. Azok a fiatalok válnak nagyobb eséllyel munkanélkülivé, akik valamilyen etnikai kisebbség tagjai, bevándorlók, fogyatékkal élnek, gazdaságilag elmaradott régiókban laknak, vagy alacsony iskolázottsággal, képzettséggel rendelkeznek (O’Higgins, 1997; Reinders, 2012). Ezek mellett több tanulmány rámutat a családi háttér kiemelt jelentőségére is (Dietrich, 2012; Eurofound, 2012a): kimutathatóan nagyobb valószínűséggel lesz NEET az a gyermek, akinek a szülei (voltak) munkanélküliek, alacsony végzettségüek, vagy elváltak. Valójában ezek a jellemzők erőteljesen összefonódnak, legtöbbször egyikből következik a másik. Éppen ezért elmondható, hogy a (szocio-kulturális értelemben vett) hátrányos helyzet felfogható a munkanélküliség személyes (egyedi) okának, ám a legtöbb esetben ez társadalmi és gazdasági folyamatok eredményeként alakul ki. Szorosan kapcsolódik hozzá a szegénység fogalma is, amely az alacsony jövedelem és az ebből származó egyéb hátrányok összességét jelenti, amelyekből nagyon nehéz kitörni (Andorka, 2006). ${ }^{39}$

Az ifjúsági munkanélküliség okainak empirikus tesztelésével foglalkozó kutatások nagyobb része a makro szintü tényezőkre koncentrál, de vannak a mikro szintet előtérbe helyező vizsgálatok is. Qayyum (2007) 2003-2004-es adatokra támaszkodva a pakisztáni ifjúsági munkanélküliség okait három szempont szerint vizsgálja: a személyes jellemzők (életkor, nem, családi állapot), a földrajzi hely (melyik tartományban él), valamint a végzettség szerint. Eredményei alapján meghatározó, hogy az adott fiatal melyik tartományban él, de általánosságban igaz, hogy valaki nagyobb valószínűséggel lesz munkanélküli, ha fiatal, ha nő, ha nem házas; illetve minél magasabb iskolai végzettséggel rendelkezik. Ez utóbbi eredmény a fejlett országokban meghökkentő lenne, de Pakisztánban a fiatalok sokszor már azelőtt dolgozni kezdenek, hogy iskolába járnának. A magasabb végzettségủek így jóval nagyobb bért kínáló állásokat kívánnak betölteni, amelyeknek a száma viszont korlátozott. A szakmai gyakorlat (technical/vocational training) viszont növeli az elhelyezkedés esélyét.

Az ifjúsági munkanélküliséghez vezető makro szintű tényezők elméletben szétválaszthatóak strukturális és intézményi okokra, de a gyakorlatban ezek erőteljesen összefonódnak, ezért együtt tárgyaljuk őket. Mind a strukturális, mind az intézményi okok

\footnotetext{
${ }^{39}$ A szegénység okainak azonosítása a társadalomtudományok egyik leghangsúlyosabb kérdése, és számos szociológiai elmélet született erről. Az egyenlőtlenség forrásaként a spektrum egyik végpontján a biológiai adottságok különbözőségét megnevező elmélet áll, a másik végén pedig a gazdasági-társadalmi rendszer jellegét tekintik a fó oknak (Andorka, 2006). Ezek részletes ismertetése azonban messzire vezetne a dolgozatunk fö témájától.
} 
kapcsolatban állnak az iskolából a munkába való átállás nehézségeivel, és leginkább a szakmai tapasztalat hiányára vezethetőek vissza.

Alapvető probléma, hogy a megszerzett végzettség sokszor nem piacképes, vagyis az oktatás/képzés és a munkapiac igényei nem állnak összhangban (Choudhry et al., 2012; Eurofound, 2012a). Európában ez jelentős probléma, amit az is jól mutat, hogy az Európai Bizottság 2010-ben, az „Új készségek és munkahelyek menetrendje” (Agenda for new skills and jobs) címü dokumentumban megállapította, hogy állandó eltérés áll fenn az álláskeresők készségei, képesítése és a munkaerőpiac igényei között: ezt a munkapiaci illeszkedés hibájának (skills mismatch) nevezhetjük. ${ }^{40}$ Ezeket az eltéréseket két nagyobb csoportba lehet sorolni: vertikális és horizontális (ILO, 2014).

Vertikális illeszkedési hibának tekinthető, ha a képzettség szintje nem megfelelő. Ennek egyik fajtája a készséghiány (skill deficit) vagy felkészültséghiány (skill shortage), amikor a pályázó/dolgozó nem elég képzett a pozíció betöltéséhez; a másik a készség-kihasználatlanság (skill underutilisation), amely túlképzettséget jelent (House of Lords, 2014). A készséghiány következtében az álláskereső vagy nem talál állást, vagy talál, de ott az optimálisnál alacsonyabb termelékenységgel tud dolgozni. Sokszor a túlképzettség is munkanélküliséghez vezet (a munkaadók nem akarnak/tudnak magasabb bért fizetni a munkáért), valamint, ha a túlképzettség mellett a készségek és tudás (skill) szintje is magasabb a szükségesnél, akkor a munkavégzés során fellép a készség-kihasználatlanság, amely készségvesztéshez vezethet.

Horizontális az illeszkedési hiba, ha a munkakereslet és munkakínálat minőségében tér el, vagyis bizonyos szakképesítéseket a kereslethez képest túl sokan vagy épp túl kevesen szereznek meg. A munkapiaci illeszkedés hibája, valamint általában a képzettség problematikája egyértelmủen összekapcsolható a 3.1. alfejezetben ismertetett Klau és Mittelstadt (1986)-féle foglalkozások és vállalatok közötti alkalmazkodóképesség, valamint a Reed (2010) által meghatározott összetételi rugalmasság dimenzióval.

A munkapiaci illeszkedés hibájának okait illetően többféle elmélet is létezik. Ezek összefoglalását adja Desjardins és Rubenson (2011, 15-22. o.). Az 1960-as években elterjedt neolkasszikus alapokon nyugvó humán tőke elmélet még csak az oktatás termelékenységnövelő hatására fókuszált, és azt állította, hogy bár rövid távon felmerülhet, de a piaci erők következtében létrejövő egyensúlyban hosszú távon nem marad fenn az illeszkedés hibája. Később már megjelentek azok az elméletek is, amelyek (egymással átfedésben vagy egymást kiegészítve) hosszú távon is magyarázzák illeszkedési hibát.

\footnotetext{
${ }^{40}$ A munkapiaci illeszkedés hibája, a megfelelő képzettség hiánya az idősebb (50 év feletti) álláskeresők esetében is megjelenik - és a CDPS (2001) szerint még inkább elterjedt jelenség, mint a fiatalok között.
} 
1. A technológiai változás elmélete (technological change theory) szerint egyrészt a vállalatoknál (például a fejlesztések költségei miatt) elmaradhatnak a technológiai fejlesztések, és ennek következtében felléphet készség-kihasználatlanság. Másrészt a dinamikusan fejlődő szektorokban tevékenykedő vállalatok hajlamosak a ténylegesen szükségesnél magasabban képzett munkaerőt alkalmazni, hogy a jövőbeli technológiai változásokhoz könnyebben alkalmazkodjanak a foglalkoztatottak - ez pedig túlképzést (overeducation, overskilling) idézhet elő és ugyancsak készségvesztést okozhat. Harmadrészt a technológiai fejlödés következtében a munkaeröpiacra újonnan belépőktől egyre magasabb szintü képzettséget várnak el, így hozzájuk képest a már régóta foglalkoztatott emberek alulképzetté válhatnak (vagy csak annak tünhetnek, ha a foglalkoztatásuk során szert tettek a szükséges készségekre, csak éppen a végzettségre nem).

2. A karrier mobilitás elmélete (career mobility theory) szerint a fejlett országokban egyre jellemzőbb a foglalkozási mobilitás, a munkakörök változtatása az aktív évek során, föként a fiatal és magasan képzett munkavállalók körében. Ezért a fiatalok igyekeznek minél magasabb szintü végzettséget megszerezni, hogy jobb előmeneteli kilátásaik legyenek - hiszen ezek kompenzálják őket a munkavállalás kezdetén várható alulfizetettségért. Így a túlképzettség egy átmeneti és tudatosan vállalt jelenségnek tekinthető. A probléma, hogy az információhiány, vagy a kedvezőtlen gazdasági körülmények gátolhatják ezt a fajta mobilitást, ekkor pedig felmerülhet a készségvesztés.

3. Az álláskeresési elmélet (job search theory) a tökéletlen informáltságra vezeti vissza az illeszkedés hibáját. Eszerint a munkavállalók nem ismerik pontosan a termelési folyamatok természetét, a munkaadók pedig a munkavállalók tényleges készségeit. Ez okozza a nem megfelelő álláskereső-álláshely párosításokat.

4. A jelzési elméletek ${ }^{41}$ (signalling theories) szerint (szemben a humán tőke elmélettel) az oktatás nem feltétlenül növeli a készségeket és a termelékenységet, és nem ez a képességek vagy készségek fejlesztésének egyetlen forrása. Ebben az esetben is az információs aszimmetria a kiindulópont. A munkavállaló tényleges termelékenysége csak egy adott idő után derül ki a munkaadó számára, így később már ehhez igazíthatja a bért, de addig az álláskereső végzettsége az, ami jelzésnek tekinthető, és amely alapján a munkaadó megbecsüli a termelékenységét. Az illeszkedési hiba oldaláról

41 A jelzési elmélet (jelző/szürő) modelljeiről, azok empirikus tesztelési kísérleteinek eredményeiről összefoglalást ad Kun (2013). 
közelítve ez arra ösztönzi az embereket, hogy minél magasabb végzettséget szerezzenek ('́gy bocsátanak ki jelzést a munkaadók felé), ami önmagában nem vezet túlképzettséghez, csak ha a munkaadó (az álláskeresők termelékenységére vonatkozó pontos információk hiányában) a szükségesnél magasabb végzettségü munkavállalókat alkalmaz (ezáltal később felmerülhet a készségvesztés is).

5. Az állásverseny elmélet (job competition theory) illeszkedési szempontból releváns eredménye hasonlít a jelzési elméletekéhez. Eszerint a bérek nem feltétlenül az egyéni teljesítmény függvényében alakulnak, hanem például a munkakör jellegzetességei és a bérmeghatározó intézmények tevékenysége nyomán. A munkáltatók keresik a munkavállalókat és jobban érdeklődnek a képzettebb munkaerő iránt, mivel a képzések és a változásokhoz való alkalmazkodás szempontjából kevésbé költségesnek ítélik őket.

6. A szegmentált munkaerőpiaci elméletek ${ }^{42}$ (labour market segmentation theories) a horizontális illeszkedési hiba kialakulására adnak magyarázatot. Ezek szerint (hasonlóan az állásverseny elmélethez) a béreket elsősorban nem a dolgozók humán tőke színvonala határozza meg, hanem maga a betöltött állás (munkakör) és a technológia. A duális-szegmentált munkaerőpiac elméletében a primer (,jó állások”) és szekunder (rosszul fizetett és bizonytalan állások) részpiac között tartós jövedelmi különbségek állnak fenn és számos akadálya van a két részpiac közötti átjárásnak.

7. A munkahelyekhez való hozzárendelés elmélete (job assignment theory) elismeri az oktatás termelékenységnövelő hatását, de emellett azt is, hogy az állás (munkakör) is ugyanolyan mértékben meghatározza a munkavállaló termelékenységét és a bérét. Tehát a munka kínálata és kereslete egyaránt fontos.

8. Mindezek mellett a diszkrimináció (discrimination theory) hatása is megjelenik a munkapiaci illeszkedés problémájában.

Még ha a pályakezdő fiatal végzettsége keresett is a munkapiacon, az elhelyezkedést gyakran nehezíti a szakmai tapasztalat hiánya. Ennek oka, hogy a vállalatok számára költséges az új munkavállalók betanítása, ezért sokszor kevésbé kockázatosnak ítélik idősebb, tapasztalattal rendelkező munkaerőt alkalmazni, szemben a bizonytalan színvonalú humán tőkét képviselő tapasztalatlan, „nem kipróbált” fiatalokkal (Choudhry et al., 2012; Eurofound, 2012a). Ezen a problémán segíthet a szakmai gyakorlatot is magába építő oktatási és képzési rendszer, föként az alacsonyabb végzettségüek körében (Wolbers, 2007).

\footnotetext{
${ }^{42}$ A szegmentált munkaerőpiaci elméletekkel foglalkoztunk már a 2.2. alfejezetben.
} 
Sokszor a már alkalmazásban álló fiatalok helyzete is bizonytalanabb, mint az idősebbeké. Általánosan elfogadott álláspont, hogy az üzleti ciklusokra érzékenyebben reagál e korosztály foglalkoztatása (IMF, 2014; Kawaguchi-Murao, 2012). Noha számos empirikus vizsgálat alátámasztja, hogy recesszió idején a fiatalok munkanélküliségi rátái jobban emelkednek, mint az idősebbeké (Banerji et al., 2014; Choudhry et al., 2012; IMF, 2014), Artner (2013) cikkében a fiatalok összes munkanélkülieken belüli arányának alakulását vizsgálva arra az eredményre jut, hogy a 2007-2008-as válság során az Európai Unióban - bár valóban kiemelkedő a fiatalok munkanélküliségi rátájának növekedése, különösen a mediterrán országokban (Görögország, Spanyolország, Olaszország, Portugália) - szinte minden tagállamban csökkent a fiatalok munkanélkülieken belüli aránya. ${ }^{43} \mathrm{Ez}$ azt jelenti, hogy a gazdasági válságok generációspecifikus hatása nem olyan egyértelmü, mint ahogy a mainstream közgazdasági szakirodalom sugallja. A fiatalok recesszió idején növekvő munkanélkülisége egyébiránt arra vezethető vissza, hogy sok fiatal dolgozik az olyan, üzleti ciklusokra érzékeny iparágakban, mint az építőipar, kereskedelem, turizmus, stb., illetve kisés közepes vállalkozásoknál, ${ }^{44}$ másrészt pedig recesszió idején a foglalkoztatás összehúzódása legelőször az új felvételt (így a munkaerőpiacra újonnan kilépő fiatalokat) érinti (Eurofound, 2012a; IMF, 2014). Emellett az is jellemző, hogy a fiatalokkal gyakran kötnek hosszabb próbaidejü vagy határozott idejü munkaszerződéseket, amelyeket kedvezőtlen gazdasági körülmények esetén könnyebben, alacsonyabb költségekkel fel tud bontani a munkáltató (Artner, 2013; Choudhry et al., 2012). Ez a munkavállaló szempontjából kedvezőtlen folyamat egyben a munkaerőpiac rugalmasságát tükrözi.

A munkapiaci intézmények is szerepet játszhatnak abban, hogy egy országban milyen mértékü az ifjúsági munkanélküliség: a munkajogi szabályok, a minimálbér, a kollektív alku és a szakszervezetek szerepe mellett a munkanélküli segélyezés rendszere, a segélyezés időtartama is meghatározó lehet. Ezek a tényezők mind szorosan kapcsolódnak a munkaerőpiac rugalmasságának kérdésköréhez.

A már dolgozó munkavállalókat védő munkajogi szabályok nehezíthetik a munkába állást, pontosabban visszatarthatják a munkaadókat a munkaerő-felvételtől (Sachs-Smolny, 2015). Ennek az az oka, hogy ezek a szabályok költségessé teszik a leépítést (például gazdasági visszaesés esetén is). Ezzel kapcsolatban a szakirodalom gyakran hivatkozik az ún. insider-

\footnotetext{
${ }^{43} \mathrm{Az}$, hogy az ifjúsági munkanélküliség relatív súlya inkább konjunktúra idején növekszik, részint annak köszönhető, hogy a szülők ilyenkor jobban el tudják tartani és iskoláztatni munka nélkül lévő gyermekeiket.

${ }^{44}$ 2013-ban az EU 28 országában a nem pénzügyi szektorban a foglalkoztatottak 66,8 százaléka KKV-nál dolgozott, ez összesen 88,8 millió embert jelent. A gazdasági válság következtében a KKV-szektorban foglalkoztatottak száma jelentősen lecsökkent, még 2013-ra is 2,6 százalékkal kisebb volt, mint 2008-ban (European Commission, 2014).
} 
outsider elméletre, melynek lényege, hogy a már alkalmazásban állók bennfentesnek tekinthetőek, akik a munkapiacra jellemző tranzakciós költségek miatt jobb alkupozícióban vannak, mint a kívülálló álláskeresők. ${ }^{45}$ Ahogyan korábban is említettük, a fiatalok esetében ezekhez a várható költségekhez az is hozzájárul, hogy a munkaadó - korábbi tapasztalat híján - előzetesen nehezen tudja felmérni a pályázó termelékenységét és képezhetőségét (Choudhry et al., 2012; Eurofound, 2012a; IMF, 2014). Hasonlóan kiszoríthatja a fiatal munkavállalókat a munkapiacról a minimálbér és a kollektív alku intézménye is (Gorry, 2013; Mankiw, 2011; Sachs-Smolny, 2015). A tapasztalatok alapján az alacsonyabb alkalmazási költségek (például alacsonyabb adóék) és az állam részéről a magasabb - jól megtervezett - aktív munkaerőpiaci politikai kiadások segíthetnek a munkanélküliség leszorításában (IMF, 2014).

A 4.5. táblázatban azok a strukturális és intézményi okok szerepelnek, amelyek a munkaerőpiaci rugalmasság (3.1. alfejezetben ismertetett) Reed és Rodgers-féle tipizálás alapján elkülöníthető dimenzióinak megfeleltethetőek. Az OECD foglalkoztatási stratégiája szerint a munkapiac rugalmasabbá tétele növeli a munkahelyteremtést és csökkenti a munkanélküliséget (és erre az ezredforduló utáni német reformsorozat jó példa) (Eichhorst, 2013). Ugyanakkor, ha nem ismerjük az ifjúsági munkanélküliség okait, akkor nehezen tudjuk azt megszüntetni azáltal, hogy egyszerüen csak a rugalmasabb munkaerőpiac felé tereljük a gazdaságpolitikai folyamatokat.

4.5. táblázat Az ifjúsági munkanélküliség okai és a munkaerőpiac rugalmassága

\begin{tabular}{lcc}
\hline Ok & $\begin{array}{c}\text { A rugalmasság } \\
\text { jellemzöje }\end{array}$ & $\begin{array}{c}\text { Független a } \\
\text { rugalmasságtól }\end{array}$ \\
\hline Strukturális & & \\
\hline Fiatalok népességen belüli aránya & $\mathrm{X}$ \\
\hline Foglalkoztatás üzleti ciklusokra érzékeny szektorokban & $\mathrm{X}$ \\
\hline Aggregált kereslet visszaesése & $\mathrm{X}$ \\
\hline Gazdasági válságok & $\mathrm{X}$ \\
\hline Szakmai tapasztalat hiánya & $\mathrm{X}$ & \\
\hline Próbaidő, határozott idejü munkaszerződés & $\mathrm{X}$ \\
\hline Részmunkaidös foglalkoztatás & $\mathrm{X}$ & \\
\hline A munkapiaci illeszkedés hibája & & \\
\hline Intézményi & $\mathrm{X}$ & \\
\hline Munkajogi szabályok & $\mathrm{X}$ & \\
\hline Minimálbér növekedése & $\mathrm{X}$ & \\
\hline Kollektív alkuk, szakszervezetek tevékenysége & \\
\hline
\end{tabular}

Forrás: Udvari-Urbánné Mező $(2015,66$. o.) alapján saját szerkesztés.

\footnotetext{
${ }^{45}$ Bővebben lásd például Lindbeck-Snower (2001).
} 


\subsection{KORÁBBI EMPIRIKUS VIZSGÁLATOK AZ IFJÚSÁGI MUNKANÉLKÜLISÉG OKAIRÓL}

Az utóbbi években egyre több olyan tanulmány születik, amely empirikus úton próbálja tesztelni az ifjúsági munkanélküliség főbb okait. Noha ezek többsége a fejlett országokra fókuszál, mind több kutatás készül a fejlődő országokra vonatkozóan is. A fiatalok munkanélküliségéhez vezető okok országonként nagyon eltérőek lehetnek, ezért érdemes néhány kutatás eredményeit kiemelni. Az ifjúsági munkanélküliség kialakulásához vezető makro szintü tényezőkkel foglalkozó (empirikus) kutatások három nagyobb csoportra oszthatóak: a fiatalok népességen belüli arányát; a gazdasági körülményeket (aggregált kereslet alakulása, válságok); valamint a fiatalok béreit elemző vizsgálatokra. A 4.6. táblázat összefoglalja a továbbiakban részletesebben ismertetésre kerülő tanulmányokat.

4.6. táblázat Empirikus vizsgálatok az ifjúsági munkanélküliség okairól

\begin{tabular}{|c|c|c|}
\hline Ok & Tanulmány & Minta \\
\hline \multirow{4}{*}{$\begin{array}{l}\text { Fiatalok népességen } \\
\text { belüli aránya }\end{array}$} & Korenman-Neumark (2000) & 15 fejlett ország; 1970-1994 \\
\hline & Roth-Moffat (2014) & 24 fejlett európai; $2007-2010$ \\
\hline & Lam (2014) & 42 fejlett és 112 fejlődő; $1990-1999$ és 2000-2009 \\
\hline & Hilson-Osei (2014) & fejlődő szubszaharai országok \\
\hline \multirow{2}{*}{$\begin{array}{l}\text { Aktuális makro- } \\
\text { gazdasági helyzet }\end{array}$} & Demidova-Signorelli (2012) & oroszországi régiók; 2000-2009 \\
\hline & Anyanwu (2014) & 46 afrikai ország; $1980-2010$ \\
\hline \multirow{3}{*}{$\begin{array}{l}\text { Bérek nagysága, } \\
\text { minimálbér }\end{array}$} & Gorry (2013) & USA és Franciaország; 2007-2009 \\
\hline & Vamossy (2014) & Magyarország; 1998-2012 \\
\hline & Neumark-Wascher (2003) & 17 OECD ország; $1975-2000$ \\
\hline
\end{tabular}

Forrás: saját szerkesztés.

\subsubsection{A NÉPESSÉGNÖVEKEDÉS SZEREPE}

Logikusnak tűnik, hogy a fiatalok száma befolyásolja a fiatal munkanélküliek számát, azonban a munkaerőpiaci feltételeknek nagyobb jelentősége van (O’Higgins, 1997). Ez a megállapítás különösen a fejlett (északi) országokra igaz. Korábban több tanulmány is igazolta, hogy az ún. „baby-boom” generációk munkaerőpiacra lépésekor az 1960-as és 1970-es években megugrott az ifjúsági munkanélküliség az USA-ban és Európában is. Manapság azonban a fejlett országokban inkább a társadalom elöregedése okoz problémákat, ezért az európai és északamerikai országokban a népességnövekedés értelemszerüen nem lehet egyedüli meghatározó oka a fiatalok munkanélküliségének, illetve még a csökkenő népességü (európai) országokban sem oldódik meg idővel magától az ifjúsági munkanélküliség problémája. A fejlődő országokra végzett vizsgálatok viszont már valamivel árnyaltabb képet mutatnak.

Korenman-Neumark (2000) a fejlett országok szemszögéből közelítik meg a jelenséget. Tanulmányukban azt vizsgálják, hogy magyarázza-e az ifjúsági munkanélküliség nagyságát a fiatalok népességen belüli aránya (cohort crowding hypothesis). Szakirodalmi 
áttekintésükben olyan korábbi - föként az Egyesült Államok adatait alapul vevő - kutatásokat sorolnak fel, amelyek eredményei alátámasztják a pozitív kapcsolatot a fiatal kohorsz és a munkanélküliség nagysága között. A szerzőpáros vizsgálata az USA, Kanada, Ausztrália, Japán és 11 európai ország esetére ${ }^{46}$ terjed ki, 1970-1994 közötti adatokat felhasználva, és arra az eredményre vezet, hogy a fiatalok népességen belüli aránya és a munkanélküliségi rátájuk között valóban pozitív kapcsolat van, de a foglalkoztatási rátát nem befolyásolja a kohorsz nagysága. Összességében az ifjúsági munkanélküliségi ráták sokkal nagyobb mértékben függnek az általános munkaerőpiaci környezettől, mint a kohorsz nagyságától. (Ez a megállapítás is indokolja a munkaerőpiaci rugalmasság szerepének vizsgálatát.)

Roth és Moffat (2014) hasonló eredményre jut 24 európai országra, NUTS 1-es és NUTS 2-es regionális szinten, 2007-2010 közötti adatokkal végzett vizsgálatában. A szerzők úgy találják, hogy a fiatal népesség nagysága és a munkanélküliségi rátája között pozitív összefüggés áll fenn, mely regionális szinten erősebb, mint nemzeti szinten; ám sokkal nagyobb jelentőséggel bír a makrogazdasági környezet alakulása, amit ugyanakkor nagyon egyszerü módszerrel, a teljes munkanélküliségi ráta változásával ragadnak meg.

Lam (2014) szintén a népességnövekedés hatásait elemzi, viszont Korenman és Neumark (2000), valamint Roth és Moffat (2014) kutatásaival ellenétben nem csak a fejlett országokra vonatkozóan végzi elemzését - az ezekre az országokra jellemző elöregedő társadalom miatt. A szerző mindazonáltal kimutatja, hogy a fejlődő országok nagy részében (Ázsiában, LatinAmerikában és Észak-Afrikában) is teljesül, hogy 40 éve nagyobb volt a fiatalok részaránya az aktív korú népességen belül, mint napjainkban. ${ }^{47}$ A 42 fejlett és 112 fejlődő ország adatait felölelő vizsgálatban a fiatalok aránya és az ifjúsági munkanélküliség nagysága közötti kapcsolat; valamit a két mutató értékeinek 1990-1999-es időszakról a 2000-2009-es időszakra bekövetkezett változásai közötti kapcsolat egyaránt nagyon gyengének mutatkozott. Mindez alátámasztja, hogy a fiatalok munkaképes lakosságon belüli arányának csökkenése (önmagában) nem eredményezi az ifjúsági munkanélküliség csökkenését.

Szubszaharai országok mintáján végzett vizsgálatot Hilson és Osei (2014), akik a kézerővel, és így alacsony hatékonysággal müködő bányákra koncentráltak (artisanal and small-scale mining). A szerzők úgy vélik, hogy Afrikában a fiatalok munkanélküliségének oka a térségben tapasztalható magas termékenységi ráta (azaz a népességnövekedés). ${ }^{48}$

\footnotetext{
${ }^{46}$ A vizsgált európai országok: Finnország, Franciaország, Németország, Írország, Olaszország, Hollandia, Norvégia, Portugália, Spanyolország, Svédország és az Egyesült Királyság.

${ }^{47}$ Lam (2014) a 15-24 év közötti népesség 15-64 év közötti népességen belüli arányát veszi alapul.

48 Elörejelzések szerint 2015-re az afrikai népesség 75 százaléka fiatal lesz, valamint 2025-re a világ fiataljainak egynegyede itt fog élni (Hilson-Osei, 2014).
} 
Viszont a szerzők azt is kiemelik, hogy ezen felül a korlátozott oktatási lehetőségek és a fejletlen munkaerőpiac is akadályozza a fiatalok elhelyezkedését.

E tanulmányok alapján egyértelműnek tünik, hogy a népességnövekedésnek van hatása a fiatalok munkanélküliségének alakulására, különösen a fejlődő (déli) országokban, azonban ez a hatás meglehetősen gyenge, így jóval nagyobb szerepet játszanak a munkaerőpiaci körülmények.

\subsubsection{AZ AKTUÁLIS MAKROGAZDASÁGI HELYZET HATÁSA}

A gazdasági helyzet szempontjából nézve O’Higgins (1997) úgy véli, az aggregált kereslet csökkenése csökkenti a munkakeresletet, de a fiatal munkaerő iránti keresletet nagyobb mértékben, mint a tapasztaltabb munkavállalókét. ${ }^{49}$ Ennek több oka is lehet. Munkakínálati oldalról közelítve a fiatalok könnyebben mondanak fel önként annak érdekében, hogy számukra megfelelőbb munkát találjanak (még recesszió idején is). Munkakeresleti oldalról nézve pedig recesszió idején a vállalatok azonnal megszüntetik a munkaerő-felvételt, ami főként a munkaerőpiacra újonnan belépőket (a fiatalokat) érinti; illetve ha leépítésre is sor kerül, akkor alacsonyabb haszonáldozati költséget jelent számukra a fiatal munkavállalóiknak felmondani, mint a régebb óta alkalmazott idősebbeknek. Az ifjúsági munkanélküliség kialakulására és tartós fennmaradására értelemszerüen a hosszú gazdasági válságok is hatással lehetnek. Ezek mellett megfigyelhető egyfajta kettős kapcsolat a munkapiaci részvétel és a munkanélküliség között, hiszen a magasabb aktivitási ráta magasabb munkanélküliséget eredményez, azonban a magas munkanélküliség eltántorítja az embereket, különösen a fiatalokat a munkaerőpiacra való belépéstől, így sokszor álláskeresés helyett a továbbtanulás mellett döntenek, ekkor pedig gazdaságilag inaktívnak számítanak.

Demidova és Signorelli (2012) tanulmányukban a fiatalok munkanélküliségének okait vizsgálják az oroszországi régiókban 2000-2009 között. Ökonometriai elemzésükben a földrajzi elhelyezkedés szerepe jelentősnek bizonyult: az adott régió gazdasági fejlettsége és kereskedelmi nyitottsága csökkentette az ifjúsági munkanélküliség valószínűségét, de ezek mellett jelentős szerepe volt a demográfiai és migrációs tényezőknek, valamint a családi háttérnek és az intézményi feltételeknek is. A szerzők az ifjúsági munkanélküliséget általánosan meghatározó fő okok áttekintése során a következő tényezőket emelik ki: makrogazdasági feltételek és ingadozások; a fiatalokra jellemző alacsonyabb színvonalú vagy nem a

${ }^{49}$ Ez a megállapítás azonban nem tekinthető általános érvényünek. A 4.1. alfejezetben bemutattuk, hogy a 2008-as válság kezdete óta az EU fejlettebb tagállamaiban valóban növekedett a fiatalok munkanélküliségének relatív jelentősége, de összességében az ifjúsági munkanélküliség relatív súlya csökkent az Európai Unióban. 
munkakereslethez igazodó humán tőke (azaz a munkapiaci illeszkedés hibája) és alacsony termelékenység; valamint intézményi feltételek, különösen az iskola-munka közötti átmenetet meghatározó tényezők. A válságok hatását tekintve azt állapítják meg, hogy a gazdasági visszaesést kísérő leépítések során a fiatalok - elsősorban az alacsony iskolázottságúak veszítik el elsőként az állásukat, mivel ők gyakran ideiglenes munkaszerződéssel foglalkoztatottak. Ez a folyamat pedig teljes mértékben összhangban van a rugalmas munkaeröpiac müködésével.

Ugyan a fejlett és a fejlődő országok gazdasági feltételei, jellemzői teljesen eltérőek, mégis érdemes itt megemlíteni Anyanwu (2014) tanulmányát, melyben 46 afrikai országban vizsgálja 1980-2010 között az ifjúsági munkanélküliséget meghatározó tényezőket, különös hangsúlyt fektetve az afrikai kontinensen belüli kereskedelem hatására. Legfontosabb megállapításai, hogy csökkenti az ifjúsági munkanélküliséget:

- a kontinensen belüli kereskedelem növekedése (különösen a nők körében, mivel a kontinensen hagyományosan több nő dolgozik az exportszektorban);

- a hazai beruházási ráta növekedése (különösen a férfiak körében);

- a magasabb (legalább középfokú) iskolázottság (különösen a nők körében);

- az intézményesített demokrácia (gazdasági és politikai szabadság, állampolgári jogok);

- a magas infláció;

- a reál GDP növekedése;

- a növekvő urbanizációs ráta (különösen a nők körében).

Ám a vizsgálat azt is kimutatta, hogy magasabb az ifjúsági munkanélküliség azokban az afrikai országokban, amelyek nagyobb egy főre jutó GDP-vel rendelkeznek, illetve amelyekben magasabb a magánszféra hitelfelvétele; de nincs szignifikáns kapcsolat az ifjúsági munkanélküliség és a kormányzati fogyasztási kiadások, illetve az ifjúsági munkanélküliség és az FDI/GDP aránya között.

\subsubsection{A BÉREK NAGYSÁGÁNAK JELENTŐSÉGE}

A szakirodalomban többen is foglalkoztak a munkabérek és a fiatalok munkanélkülisége közötti kapcsolat elemzésével. Ez a kérdéskör elemzésünk szempontjából is fontos, hiszen a 3. fejezetben láthattuk, hogy a bérrugalmasság és a munkaerőköltségek a munkaeröpiac rugalmasságának meghatározó tényezői. Általánosságban elmondható, hogy az ifjúsági munkanélküliség alakulásában fontos szerepet játszhatnak a bérek, hiszen minél magasabb a fiatalok bére (vagy akár a minimálbér) az idősebbekéhez viszonyítva, a cégek annál inkább 
hajlamosak a tapasztaltabb munkavállalók alkalmazása mellett dönteni - persze csak abban az esetben, ha az idősebbek tökéletes helyettesítői a fiataloknak (O’Higgins, 1997). Valamint a minimálbér növekedése csökkenti az alacsony képzettségü és a kevés tapasztalattal bíró (azaz a fiatal) munkavállalók elhelyezkedési esélyeit (Mankiw, 2011; Vamossy, 2014).

Ugyan O’Higgins (1997) szerint a bérek nagysága a gyakorlatban nem lehet ennyire meghatározó tényező, hiszen a munkapiac nem tekinthető tökéletesen versenyző, „modellszerü” piacnak, viszont a fenti állítások igazolása több empirikus tanulmányban is megjelent. Például Gorry (2013) az Egyesült Államokra és Franciaországra vonatkozó kutatásában a minimálbér fiatalok munkanélküliségére gyakorolt hatását vizsgálta. Kimutatta, hogy az USA-ban a 2007-2009 közötti minimálbér emelkedés 2,8 százalékponttal növelte meg az ifjúsági munkanélküliséget, és konklúziójában kiemeli, hogy ha Franciaországban a minimálbért és a fizetéshez kapcsolódó adókat az USA szintjére csökkentenék, akkor jelentősen csökkenne az ifjúsági munkanélküliség az országban. Hasonló következtetéseket vont le Vamossy (2014) is regressziót alkalmazó, magyarországi vizsgálataira vonatkozóan: ezek szerint a minimálbér egy százalékos emelése egy százalékkal emelné a fiatalok munkanélküliségi rátáját. Neumark és Wascher (2003) 17 OECD országot felölelő, 1975-2000 közötti adatokkal végzett keresztmetszeti és idősoros vizsgálatokkal ugyancsak igazolta a minimálbér és az ifjúsági munkanélküliség nagysága közötti pozitív kapcsolatot, de a szerzők azt is kiemelték, hogy a minimálbér foglalkoztatást csökkentő hatása a legkevésbé szabályozott munkapiacokon a legerősebb.

A fiatal korosztály munkanélküliségéhez vezető okok áttekintése után jól látható, hogy azok valóban mutatnak eltéréseket az idősebbek körében munkanélküliséget előidéző tényezőktől, de jobbára hasonlóak, valamint, hogy ezen okok nagy része összekapcsolódik a munkapiaci rugalmasság különböző dimenzióival. Ez alapján fogalmaztuk meg a dolgozat első két hipotézisét, nevezetesen, hogy az Európai Unió tagállamaiban a nagyobb rugalmasságú munkaerőpiacokon magasabb a fiatalok foglalkoztatottsága, valamint, hogy nem jelentkezik a munkaerőpiaci rugalmasság generációspecifikus hatása. Az előbbi feltevés vizsgálatához nyújt kiindulási pontot a következő alfejezet.

\subsection{A MUNKAERÖPIACI RUGALMASSÁG HATÁSAI A FIATALOK MUNKAERÖPIACI HELYZETÉRE}

Az eddigiek alapján leszürhető, hogy a rugalmas munkaerőpiacokon a munkafeltételek jobban alkalmazkodnak a változó gazdasági körülményekhez, és egy-egy rugalmassági dimenziónak több, az ifjúsági munkanélküliség kialakulásáért felelős tényező megszüntetésében is szerepe lehet. Azonban a legtöbb rugalmassági jellemző hordoz magában negatív hatásokat is - nem 
csupán az idősebb, de a fiatal korcsoport szempontjából is. Ezeket, az ifjúsági munkanélküliség alakulása szempontjából kedvező és kedvezőtlen hatásokat foglalja össze a 4.7. táblázat.

4.7. táblázat A munkaerőpiaci rugalmasság és az ifjúsági munkanélküliség

\begin{tabular}{|c|c|c|}
\hline $\begin{array}{l}\text { A rugalmas } \\
\text { munkapiac jellemzői }\end{array}$ & $\begin{array}{l}\text { Pozitív hatások az IMN } \\
\text { szempontjából }\end{array}$ & $\begin{array}{l}\text { Negatív hatások az IMN } \\
\text { szempontjából }\end{array}$ \\
\hline Bérrugalmasság & $\begin{array}{l}\text { - Alacsonyabb kezdő fizetést } \\
\text { vállalva könnyebb belépni a } \\
\text { munkaerőpiacra } \\
\text { - Gazdasági visszaesés esetén a } \\
\text { bérek (átmeneti) csökkentésével } \\
\text { visszaszorítható a leépítések száma }\end{array}$ & $\begin{array}{l}\text { - A nagy bérrugalmasság csökkenti } \\
\text { a munkavállalói biztonságot } \\
\text { - Az átmeneti bércsökkentések } \\
\text { sokszor tartósnak/véglegesnek } \\
\text { bizonyulnak } \\
\text { - Alacsonyabb bérek alacsonyabb } \\
\text { életszínvonalhoz vezethetnek }\end{array}$ \\
\hline Munkaidő rugalmassága & $\begin{array}{l}\text { - Gazdasági visszaesés esetén a } \\
\text { részmunkaidő (átmeneti) } \\
\text { alkalmazásával visszaszorítható az } \\
\text { elbocsátások száma } \\
\text { - A családalapítást támogatja a rész- } \\
\text { és a rugalmas munkaidő } \\
\text { lehetősége }\end{array}$ & $\begin{array}{l}\text { - Esetenként kényszerü } \\
\text { részmunkaidős foglalkoztatást } \\
\text { eredményez } \\
\text { - A részmunkaidős foglalkoztatás } \\
\text { növeli a bizonytalanságot és } \\
\text { általában alacsonyabb bérrel jár }\end{array}$ \\
\hline $\begin{array}{l}\text { Mobilitás } \\
\text { (alkalmazás és } \\
\text { elbocsátás költségei; } \\
\text { oktatás és képzés; } \\
\text { ALMP) }\end{array}$ & $\begin{array}{l}\text { - Társadalmi szinten orvosolható a } \\
\text { munkapiaci illeszkedés hibája } \\
\text { (oktatás és képzés) } \\
\text { - Az oktatás és szakmai gyakorlat } \\
\text { összekapcsolásával tapasztalatot } \\
\text { szereznek a fiatalok is } \\
\text { - A földrajzi és vállalatok közötti } \\
\text { mobilitás is segíti a könnyebb } \\
\text { belépést a munkaerőpiacra } \\
\text { - Az alkalmazáshoz és } \\
\text { elbocsátáshoz kapcsolódó } \\
\text { alacsonyabb költségek mérséklik } \\
\text { az insider-outsider csoportok } \\
\text { közötti különbséget a munkaadó } \\
\text { szempontjából }\end{array}$ & $\begin{array}{l}\text { - A földrajzi mobilitás } \\
\text { következtében széthullhatnak a } \\
\text { családok (szociális) } \\
\text { - Az alkalmazáshoz és elbocsátáshoz } \\
\text { kapcsolódó alacsonyabb költségek } \\
\text { következtében csökken a } \\
\text { munkavállalói biztonság }\end{array}$ \\
\hline
\end{tabular}

Forrás: Urbánné Mező-Udvari (2016, 450. o.).

Az üzleti ciklusokhoz való rugalmasabb, átmeneti alkalmazkodást segíti a részmunkaidős foglakoztatás lehetősége, vagy akár a földrajzi mobilitás, de a (lefelé irányuló) bérrugalmasság is. A Nemzetközi Munkaügyi Szervezet (ILO, 2015a) fiatalok foglalkoztatásával foglalkozó legutóbbi kiadványában rámutat, hogy a fejlett országokban az ezredforduló óta tartó trend, hogy egyre több fiatal dolgozik részmunkaidőben. E szerint az OECD országok esetében 2000ben a fiatal foglalkoztatottak 20,7 százaléka dolgozott heti 30 óránál kevesebbet, 2013-ban viszont már 30,1 százalékuk. Az oktatásban való részvétel melletti részmunkaidős munkavállalás számos pozitív hatással bír, hiszen hozzásegíti a fiatalokat a munkatapasztalat megszerzéséhez, ezáltal megkönnyíti az iskola és munka közötti átmenetet. Mégsem minden fiatal elégedett a részmunkaidős állásával, különösen azok, akik már nem tanulnak; és ez a megítélés az országok szociokulturális hátterén is múlik. Az OECD országokban a válság évei alatt (2007-2013) jelentősen megnövekedett a nem önkéntesen részmunkaidőben dolgozók 
részmunkaidősökön belüli aránya: 14,1 százalékról 17,8 százalékra, és még 2015-ben is a részmunkaidőben alkalmazott fiatalok 17,4 százaléka dolgozott volna inkább teljes állásban (OECD.Stat, 2017). Gazdasági visszaesés idején a munkaidő (és/vagy a bérek) csökkentése révén visszaszorítható az elbocsátások száma, azonban a munkáltatók sok esetben a korábbi, magasabb fizetéssel járó munkamennyiséget várják el a részmunkaidős alkalmazottaiktól is.

Az alkalmazás és elbocsátás költségeinek csökkentése (a munkajogi szabályok lazítása, a szakszervezetek szerepének csökkenése a bérek meghatározásában) mérsékli a munkaerőpiaci insider (már dolgozó idősebbek) és outsider (pályakezdő) csoportok közötti érdekérvényesítő képességbeli különbséget és a munkáltató számára az új dolgozó alkalmazásával járó kockázatot, így ugyancsak megkönnyíti a fiatalok munkaerőpiacra való belépését. Bár a flexibilitás növelése mindezek szerint számos pozitív változást eredményez a fiatalok foglalkoztathatóságának növelése terén, mégsem old meg minden problémát, sőt, nem egyszer újakat vet fel, elsősorban a munkahely biztonságát, a foglalkoztatás minőségét illetően.

$\mathrm{Az}$ oktatás és képzések munkaerőpiaci igényekhez történő jobb alkalmazkodását segíthetik az ALMP-re fordított kiadások. A gyakorlati képzések révén orvosolható a munkapiaci illeszkedés hibája és elősegíthető az első munkahely megszerzéséhez szükséges szakmai tapasztalat megszerzése. A munkapiacon értékes tudás megszerzése révén a fiatalok nem kényszerülnek (olyan nagy számban) arra, hogy szaktudást nem igénylő munkaköröket töltsenek be. Annál is inkább jelentősek a jól megtervezett aktív munkaerőpiaci politikák, mert a leszakadó társadalmi csoportok felemelkedésének kulcsa a gyermekek és fiatalok lehetőségeinek kiterjesztése (ILO, 2015a).

Mivel a korábbiakban láttuk, hogy a munkaerőpiaci rugalmasság gyakran nemkívánatos társadalmi következményekkel jár, ezért ismét kiemeljük a rugalmasság „öncélú” növelésével ellentétben a flexicurity koncepció nagy előnyét, mégpedig, hogy az alkalmas ilyen szociális szempontok figyelembe vételére is. (Egy egyszerü, a társadalom elöregedésének problémájához is kapcsolódó példa a rugalmasság és a biztonság egyidejü szükségességére, hogy a részmunkaidő lehetősége visszafoghatja a családalapítás időbeli kitolódását, de csak akkor, ha közben elérhetőek gyermekgondozási szolgáltatások is.)

A továbbiakban ismertetjük, hogy az Európai Unió közösségként milyen válaszokat ad az ifjúsági munkanélküliség kihívására, valamint bemutatjuk néhány jól teljesítő ország kiemelt jelentőségű foglalkoztatáspolitikai lépéseit. Ezek az esetpéldák tanulsággal szolgálhatnak más országok számára is. Mindeközben igyekszünk megragadni a munkapiaci rugalmasság jellemzőit a foganatosított intézkedésekben. 


\section{AZ EURÓPAI UNIÓ VÁLASZAI AZ IFJÚSÁGI MUNKANÉLKÜLISÉGRE}

Az Európai Unió már a válságot megelőzően is foglalkozott az ifjúsági munkanélküliség problémájával, különösen az ezredforduló óta (Lahusen et al., 2013). Ennek ellenére nem jött létre külön egységes közösségi politika a fiatalok között tapasztalható munkanélküliség leszorítására, nem létezik ,az EU ifjúsági foglalkoztatáspolitikája” (Chabanet, 2014). Ezért a fiatalok munkavállalását segítő intézkedések az uniós ifjúságpolitika és foglalkoztatáspolitika keretein belül születnek, valamint kiemelten fontos szerep jut az Európa 2020 stratégiának is. Ám mivel az ifjúsági munkanélküliség szintje alapvetően a nemzetgazdasági eredményektől és politikáktól függ, a téma elemzésekor nem lehet eltekinteni a tagállami szintü lépések (legalább érintőleges) ismertetésétől. A következőkben azokkal a kezdeményezésekkel foglalkozunk, amelyek a fiatalok álláshoz jutását segítik: előbb uniós, majd tagállami szinten. A fejezet végén röviden összefoglaljuk, hogy mely eszközök tünnek a legsikeresebbnek.

\subsection{KÖZÖSSÉGI ESZKÖZÖK}

Az EU egyik legfontosabb közös politikáját képezi az uniós foglalkoztatáspolitika, ${ }^{50}$ amelynek jogalapját az Európai Unióról szóló szerződés (EUSZ) és az Európai Unió működéséről szóló szerződés (EUMSZ) egyes cikkei jelentik. Célja a magas szintű foglalkoztatás kialakulásának támogatása, és ennek érdekében az 1950-es évektől léteznek támogatások, ám valójában 1993-tól (A növekedésről, a versenyképességről és a foglalkoztatásról szóló fehér könyv megjelenésétől) került a foglalkoztatás kérdése az európai napirend fókuszába. Ezt követően több foglalkoztatási stratégia követte egymást: a luxemburgi folyamat (1997-2004), a lisszaboni stratégia (2000-2010), valamint a jelenleg érvényben lévő Európa 2020 stratégia (2010-2020).

Az ifjúságpolitika ${ }^{51}$ ezzel szemben nemzeti szakpolitikai terület az Európai Unióban, a tagállamok jogszabályainak összehangolása - az EUMSZ 165. és 166. cikke alapján - nem valósul meg. Ennek ellenére vannak közös ifjúságügyi célok az Unióban, mint a szakképzéshez való hozzáférés elösegítése, valamint az oktatók, gyakornokok, és különösen a fiatalok mobilitásának ösztönzése. Így 2002 óta létezik egy stratégiai együttmüködési keret az ifjúságpolitika területén, amely időről időre megújításra kerül: jelenleg a 2010-2018 közötti időszakra szóló uniós stratégia van érvényben, amelynek két fő célkitüzése a több esély és esélyegyenlőség teremtése minden egyes fiatal számára az oktatásban és a munkaerőpiacon,

${ }^{50}$ Bővebben: http://www.europarl.europa.eu/ftu/pdf/hu/FTU 5.10.3.pdf
${ }^{51}$ Bővebben: $\underline{\text { http://www.europarl.europa.eu/ftu/pdf/hu/FTU 5.13.5.pdf }}$ 
valamint a fiatalok aktív polgári szerepvállalásának, társadalmi befogadásának és szolidaritásának előmozdítása. Ezeknek megfelelően a stratégia nyolc cselekvési területet határoz meg: oktatás és képzés, foglalkoztatás és vállalkozói készség, egészség és jólét, részvétel, önkéntes tevékenységek, társadalmi befogadás, az ifjúság és a világ, valamint kreativitás és kultúra. Az ifjúságpolitika, illetve az annak célkitűzéseit támogató intézkedések (az egyéni tanulmányi mobilitás különféle csereprogramokkal és hálózatépítő tevékenységekkel, az együttmüködés az innováció és a jó gyakorlatok területén az aktív polgárság és a vállalkozói szellem segítésére, valamint a fiatalokkal folytatott párbeszéd) finanszírozása 2014-2020 között az Erasmus+ program 1,477 milliárd eurós költségvetéséből valósul meg.

Az Unió ifjúságpolitikájának másik nagy szelete a gyermekek és fiatalok védelmének biztosítása, ami egyszerre jelenti a gyermekek jogainak védelmét, a gyermekekkel és fiatalokkal szembeni erőszak megelőzését és a médiaszolgáltatások tartalmának ellenőrzését.

A válság az Európai Uniót rendkívül mélyen érintette, mivel olyan súlyos problémákat hozott a felszínre, mint a lassú és nem fenntartható gazdasági növekedés vagy a munkaerőpiac strukturális problémái. Ebben a környezetben született meg 2010-ben az Európa 2020 stratégia a lisszaboni stratégia folytatásaként. Míg a lisszaboni stratégia célja még az volt, hogy az Európai Unió 2010-re a világ legversenyképesebb térségévé váljon, az Európa 2020 már a közösség versenyben tartására fókuszál. Célja, hogy az Unió gazdaságilag és társadalmilag is megerősödjön (Európai Bizottság, 2010; Körösi, 2012). „Az intelligens, fenntartható és inkluzív növekedés stratégiája” azt jelenti, hogy Európa olyan tudás- és innováció-alapú, a környezeti fenntarthatóságot szem előtt tartó versenyképes gazdasággá kíván válni, amelyben megvalósul a magas foglalkoztatás és a társadalmi és területi kohézió. Ennek érdekében uniós és tagállami szintü intézkedéseket egyaránt tenni kell - utóbbiakat az országjelentések segítik, illetve az európai szemeszter, mint a gazdaságpolitikai koordináció éves ciklusa. A Bizottság pontos célokat fogalmazott meg 2020-ra a stratégia megvalósítása érdekében, melyeket öt csoportba sorolt:

1. Foglalkoztatás: legalább 75 százalékos legyen a foglalkoztatási arány (a 20-64 évesek körében).

2. K+F: az Unió GDP-jének legalább 3 százalékát kutatás-fejlesztésre kell fordítani.

3. Éghajlatvédelem és fenntartható energiagazdálkodás: az éghajlatváltozás kezelése érdekében az üvegházhatást okozó gázok kibocsátását az 1990-es szinthez képest 20 (vagy 30) százalékkal kell csökkenteni; a megújuló energiaforrások arányát 20 százalékra növelni; az energiahatékonyságot 20 százalékkal javítani. 
4. Oktatás: a korai iskolaelhagyók arányát (a 2010-es 15 százalékról) 10 százalék alá kell szorítani; a 30-34 év közöttiek legalább 40 százaléka rendelkezzen felsőfokú végzettséggel.

5. Küzdelem a szegénység és a társadalmi kirekesztés ellen: legalább 20 millióval csökkenteni kell a nyomor és kirekesztettség kockázatának kitett lakosok számát.

Az Európa 2020 hét kiemelt kezdeményezést ${ }^{52}$ fogalmaz meg, melyeket a három prioritás (az intelligens, a fenntartható és az inkluzív növekedés) alá sorol be. Ezek közül a „Mozgásban az ifjúság” kifejezetten a fiatalok szociális helyzetére és munkaerőpiaci problémáira fókuszál, de más kezdeményezések is foglalkoznak az e korosztályt érintő kérdésekkel. Az „Új készségek és munkahelyek menetrendje" célként tüzi ki a munkaerőpiacok modernizálását, a munkavállalói mobilitás fokozását, az egész életen át tartó készségfejlesztés támogatását, és a munkaerőpiaci kereslet és kínálat összehangolását. A „Szegénység elleni európai platform” célja a társadalmi és területi kohézió biztosítása és a társadalmi kirekesztettségben élők számának csökkentése.

A „Mozgásban az ifjúság” (Youth on the Move) kezdeményezés célja az oktatási rendszerek és képzések összehangolása a munkaerőpiaci igényekkel; a fiatalok ösztönzése az EU által kínált ösztöndíjak és csereprogramok kihasználására tanulás és szakmai tapasztalatszerzés céljából; valamint a fiatalok munkaerőpiacra történő belépésének (az oktatás és a munkapiaci elhelyezkedés közötti átmenet) megkönnyítése (5.1. táblázat). A Mozgásban az ifjúság projekt több kezdeményezést fog át, legfontosabb - kifejezetten, vagy tartalmából adódóan főként - fiatalok foglalkoztatását támogató részei (1) a Több lehetőséget a fiataloknak; (2) az EURES hálózat; (3) a különböző csereprogramok, ösztöndíjak; (4) az Ifjúsági garancia; valamint (5) az európai munkaerö-piaci monitor.

A „,Több lehetőséget a fiataloknak” kezdeményezés (Youth Opportunities Initiative) a munkanélküli fiatalokat támogatja: egyrészt a korai iskolaelhagyók oktatásba és képzésbe történő reintegrációjával, másrészt a diplomás fiatalok munkatapasztalat-szerzésének segítésével. A kezdeményezés része „Az első EURES-állásod” nevű foglalkoztatási mobilitási program is, melynek célja, hogy a 35 év alatti álláskeresőnek segítsen munkát vagy gyakornoki pozíciót találni más uniós országokban, Norvégiában vagy Izlandon. Maga az európai foglalkoztatási hálózat, az EURES 1993-ban jött létre az Európai Gazdasági Térség országaiban müködő foglalkoztatási szolgálatok közötti együttműködési hálózataként, hogy

52 Intelligens növekedés: „Európai digitális menetrend”, „Innovatív Unió”, „Mozgásban az ifjúság”; Fenntartható növekedés: „Eröforrás-hatékony Európa”, „Iparpolitika a globalizáció korában”; Inkluzív növekedés: „Új készségek és munkahelyek menetrendje”, „Szegénység elleni európai platform”. (Bővebben: http://ec.europa.eu/europe2020/europe-2020-in-a-nutshell/flagship-initiatives/index hu.htm) 
segítse a - természetesen nem csak fiatal - személyek szabad mozgását és a szabad munkavállalást más EU-s tagállamokban. Nem egyszerü álláskeresési portálról van szó, az EURES a határokon túli ingázáshoz szükséges információkkal is ellátja a munkavállalókat és az esetlegesen felmerülö problémák megoldásában is közremüködik.

Az EU 2007-2013 között az Élethosszig tartó tanulás program (Lifelong Learning Programme, LLP) keretében közel 7 milliárd eurós költségvetésből valósította meg a legjelentősebb csere- és ösztöndíjprogramjait: a felsőoktatásban résztvevők számára az Erasmust, a szakképzésben résztvevőknek a Leonardo da Vinci programot, a felnőttképzésben tanulóknak a Grundtvig programot és az iskolák számára a Comeniust. Az LLP folytatásaként 2014-2020 között összesen 14,7 milliárd eurós költségvetéssel működik az Erasmus+ program ifjúsági fejezete, amely több mint 4 millió fiatal számára teszi lehetővé, hogy másik tagországban (vagy akár harmadik országban) tanuljon vagy végezzen szakmai gyakorlatot. Ezek a programok szintén hozzájárulnak ahhoz, hogy a résztvevő fiatalok (később) könnyebben találjanak állást, hiszen új készségeket sajátítanak el, s eközben mélyítik idegennyelv-tudásukat is.

Az EU Miniszterek Tanácsa 2013 áprilisában fogadta el az Ifjúsági garancia létrehozásáról szóló Bizottsági ajánlást (Európai Bizottság, 2013). Az ajánlás a 2012-ben elfogadott ifjúságfoglalkoztatási intézkedéscsomag (Youth Employment Package) keretein belül született. Az Ifjúsági garanciaprogram egy strukturális reform, amelynek célja, hogy a 25 év alatti fiatalokat segítse az álláskeresésben, hogy az oktatási rendszerből kilépve vagy munkanélkülivé válásuktól számítva négy hónapon belül minőségi állásajánlatokhoz, továbbképzéshez, gyakorlati képzéshez vagy szakmai gyakorlathoz jussanak. Ennek során humántőke-beruházások valósulnak meg. Az ifjúsági garancia kiépítése a tagállamok feladata a saját költségvetésük terhére (és minden tagállam be is nyújtotta az erre kidolgozott nemzeti tervét), de az EU az Európai Szociális Alapból (ESZA) származó pénzügyi támogatással segíti őket. Azokat a tagállamokat, amelyekben a legnagyobb mértékủ az ifjúsági munkanélküliség (meghaladja a 25 százalékot) és inaktivitás, az Unió egy további pénzügyi eszközzel is támogatja, szintén az ESZA forrásaiból: ez az ifjúsági foglalkoztatási kezdeményezés (Youth Employment Initiative, YEI). Ez az eszköz az egyének megsegítésére koncentrál, nem strukturális reformokat jelent. Három finanszírozási forrása a Nemzeti ESZA előirányzatok (3,2 milliárd euró), külön uniós előirányzatok (3,2 milliárd euró), és az ESZA-rész nemzeti társfinanszírozása. 
5.1. táblázat Az EU föbb közös ifjúsági foglalkoztatási eszközeinek jellemzői

\begin{tabular}{lll}
\hline A program neve & $\begin{array}{l}\text { Kezdet/ } \\
\text { időszak }\end{array}$ & Főbb célok \\
\hline Mozgásban az ifjúság & 2010 & oktatás és foglalkoztathatóság \\
\hline Több lehetőséget a fiataloknak & 2011 & reintegráció az oktatásba \\
\hline Az első EURES-állásod & 2012 (pilot) & munkavállalás segítése más tagállamban \\
\hline Ifjúsági garancia & 2013 & négy hónapon belül állás \\
\hline Ifjúsági foglalkoztatási kezdeményezés & 2013 & pénzügyi támogatás a leszakadóknak \\
\hline Élethosszig tartó tanulás program & $2007-2013$ & csere- és ösztöndíjprogram \\
\hline Erasmus+ & $2014-2020$ & csere- és ösztöndíjprogram \\
\hline
\end{tabular}

Forrás: saját szerkesztés.

$\mathrm{Az}$ európai munkaerő-piaci monitor (European vacancy monitor, EVM) nem kifejezetten fiatalok számára jött létre, de nagy jelentőséggel bír. Célja, hogy naprakész információt nyújtson az európai munkaerőpiac rövid távú változásairól. Az uniós és a tagállami foglalkoztatási szolgálatoktól gyüjtött adatok alapján tájékoztatást ad a hiányszakmákról, így erősíti az oktatás és a munkapiac összehangolását és a munkapiaci illeszkedés hibájának csökkentését. Ezért mondhatjuk, hogy bár nem csupán a fiatalokat segíti ez az eszköz, mégis a továbbtanulás és pályaválasztás előtt álló fiatalok számára kiemelten hasznos információkat szolgáltat.

Összességében ezekről, a fiatalok munkapiaci helyzetének javítását célzó programokról elmondható, hogy öt lépcsőfokra épülnek, melyekben nagy szerep jut az oktatási rendszereknek (Eurofound, 2012a):

1. a korai iskolaelhagyás és lemorzsolódás megelőzése;

2. a korai iskolaelhagyók visszasegítése az oktatásba, képzésbe;

3. segítség az iskola befejezése és a munkába állás közti időszakban;

4. tovább- és szakképzések a foglalkoztathatóság növelésére;

5. segítség a hátrányos helyzetű csoportok számára.

A programok közül nem mind tekinthető sikeresnek. Bár természetesen vannak jobban teljesítő országok, még ezekben is fennmaradt a magas munkanélküliség az alacsonyan képzett fiatal munkaerő, különösen a nők és az etnikai kisebbségek körében (Sarfati, 2013). Ezzel együtt szükség van a tagállami szinten megvalósuló lépések mellett az uniós szintủ cselekvésre, hiszen az egyes tagállamokban jelentkező magas (ifjúsági) munkanélküliség társadalmi és gazdasági szempontból is kihatással van a többi uniós országra, így magára az EU-ra is (House of Lords, 2014). És mivel leginkább az elmaradottabb (NUTS2 szintü) régiókban állandósul a magas munkanélküliség a fiatalok között, nagy szerepe van az EU regionális politikájának is a kérdésben (Perugini-Signorelli, 2010). 
Tekintettel a tagállamok közötti heterogenitásra (például a válság által leginkább érintett szektorokban dolgozó munkaerő jellemzőiben) az Európai Uniót nagyon nehéz egységként kezelni, amikor a munkaerőpiacról beszélünk. Éppen ezért az is nehezen ragadható meg, hogy a fentebb ismertetett közös politikák, közösségi kezdeményezések összességében milyen eredményeket hoztak az európai munkaerőpiacokon. Ezért érdemes egyes tagállamok helyzetét megvizsgálni.

\subsection{KIEMELT TAGÁLLAMI GYAKORLATOK}

Az ifjúsági munkanélküliség csökkentésére az Európai Unió közösségi programjai önmagukban nem hozhatnak átütő eredményt, ezt a problémát nem lehet uniós szinten megoldani. Noha a munkaerőpiaci szabályozás egyre rugalmasabbá válik Európa-szerte, így e tekintetben közelednek egymáshoz az államok, a munkanélkülieket érintő (jogosultsági) szabályokban továbbra is nagy különbségek vannak az egyes országok között (Cinalli-Giugni, 2013). Ezért érdemes néhány esetpéldát megismerni, hogy lássuk, milyen lehetőségek vannak a fiatalok körében a munkanélküliség visszaszorítására.

Ebben az alfejezetben bemutatjuk az Európai Unió hét tagállama által foganatosított főbb intézkedéseket, mint jó gyakorlatokat, amelyek segítettek illetve segíthetnek az ifjúsági foglalkoztatottság növelésében. Az alfejezetnek tehát nem célja a kiemelt tagállamok foglalkoztatáspolitikájának teljeskörü bemutatása, itt csupán néhány - más tagországok számára is elérhető - eszközt ismertetünk. Az ezekben az országokban jellemző ifjúsági foglalkoztatási és munkanélküliségi adatokat mutatja be az 5.1., 5.2., 5.3. és 5.4 ábra. A kiemelt tagállamok a következők:

- Hollandia, Németország, Dánia: mint a válság során is alacsony munkanélküliségi rátákkal rendelkező országok;

- az Egyesült Királyság és Svédország: mint az EU átlag körüli, de annál kedvezőbb helyzetben lévő országok;

- Litvánia: akit a válság súlyosan érintett, de hamar rendkívüli javulást ért el az ifjúsági munkanélküliség terén; valamint

- Magyarország.

A munkanélküliség (és ezen belül a fiatalok közötti munkanélküliség) problémájának kezelése érdekében az országok kormányai több típusú intézkedést is hozhatnak. Egyik oldalról a célkitűzés a munkanélküliek szociális segítése, hogy ezen időszak alatt ne lehetetlenüljön el a létfenntartásuk, másik oldalról pedig a mielőbbi (megfelelő) munkához jutásuk támogatása. Utóbbi cél elérésére alkalmazzák az aktív munkaerőpiaci politikai eszközöket, melyek kedvező 
hatását több makro- és mikroökonómiai vizsgálat is igazolta (lásd Nickell et al., 2005, 6. o.). A válság kirobbanása után a Bizottság még 2008-ban elfogadta a 800/2008. sz. EK rendeletet, az általános csoportmentességi rendeletet, amelyben megerösítette, hogy - többek között - a foglalkoztatás és a képzés támogatása, valamint egyes hátrányos társadalmi csoportok munkaerőpiaci integrációjának előmozdítása olyan célok, amelyek érdekében az állami támogatás a közös piaccal összeegyeztethető (Pelle, 2010).

\section{1. ábra Ifjúsági foglalkoztatottsági ráta a kiemelt tagállamokban}

(15-24 évesek; 2000-2016; \%)

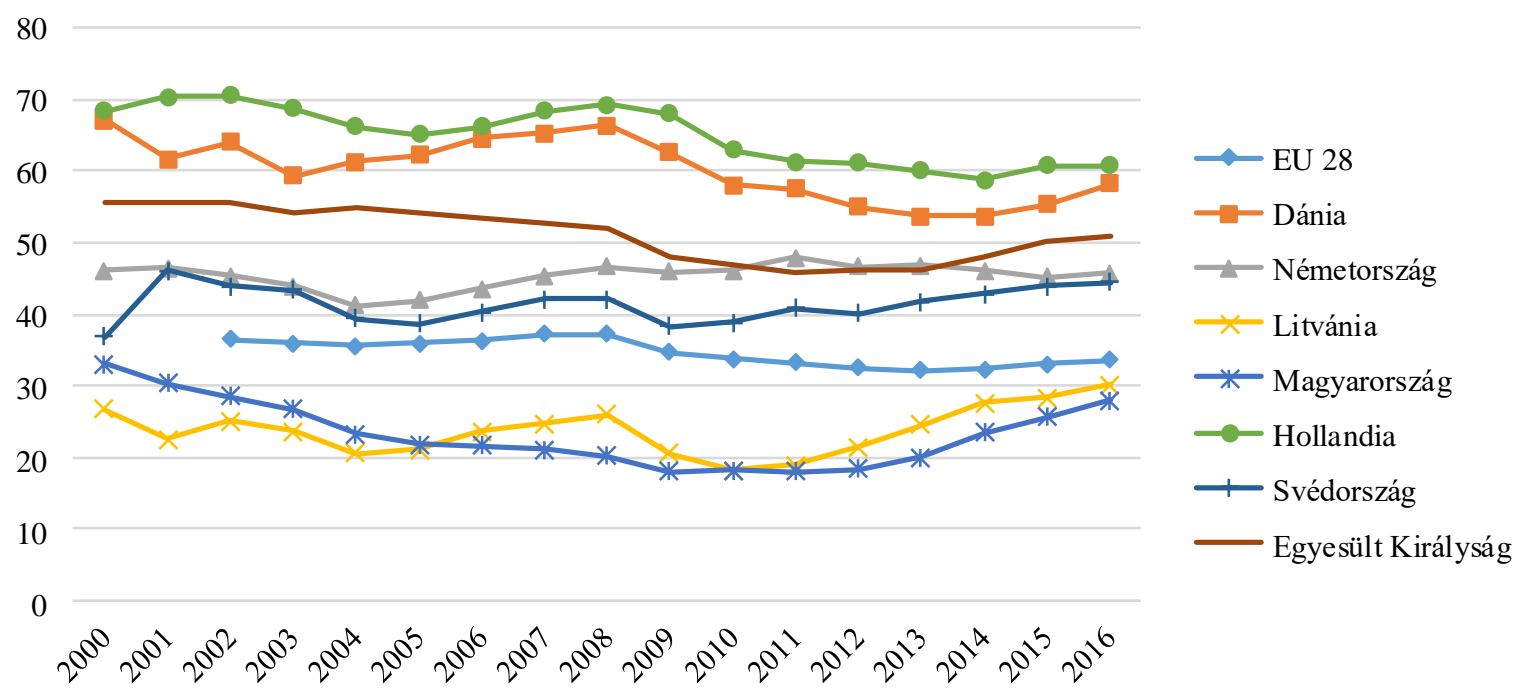

Forrás: Eurostat (2017) adatai alapján saját szerkesztés.

5.2. ábra Ifjúsági munkanélküliségi arány a kiemelt tagállamokban (15-24 évesek; 2005-2016; \%)

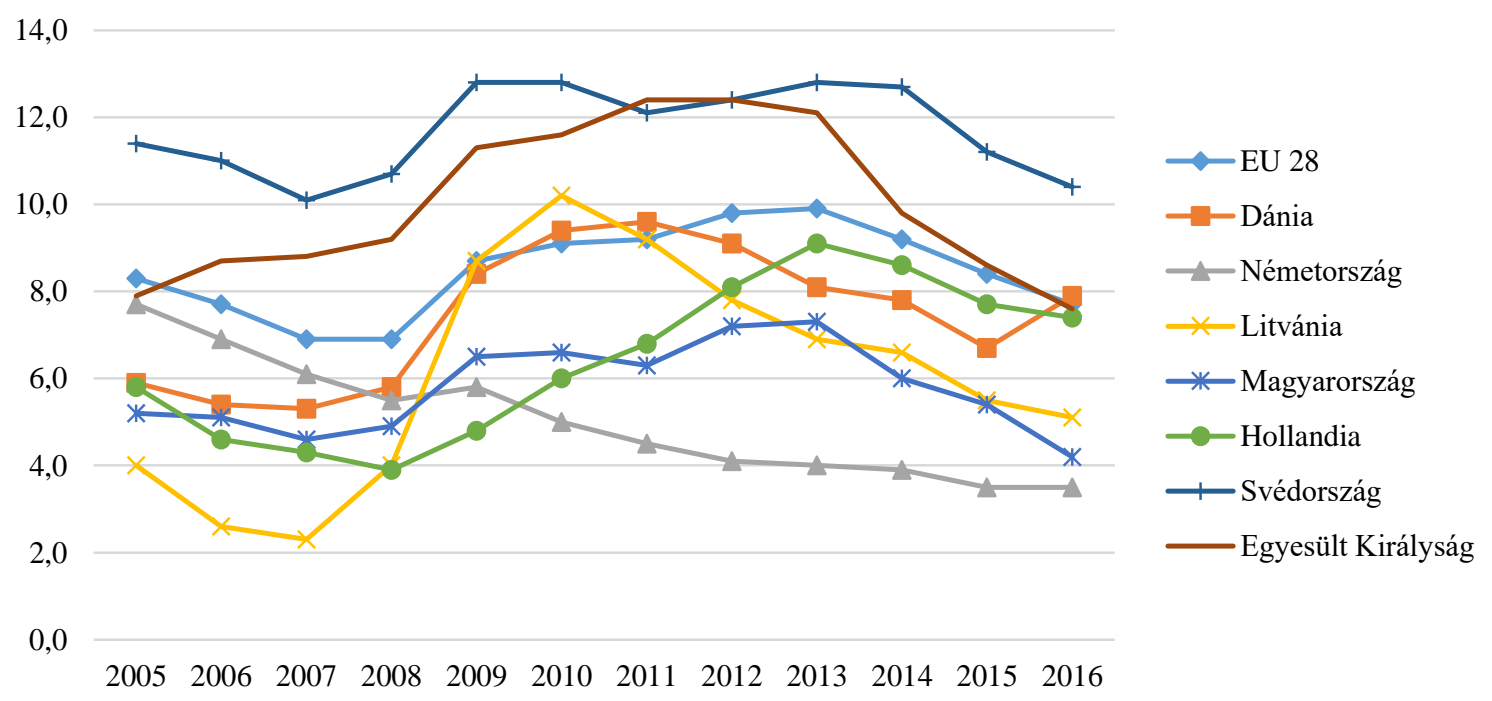

Forrás: Eurostat (2017) adatai alapján saját szerkesztés. 
5.3. ábra Ifjúsági munkanélküliségi ráta a kiemelt tagállamokban (15-24 évesek; 2000-2016; \%)
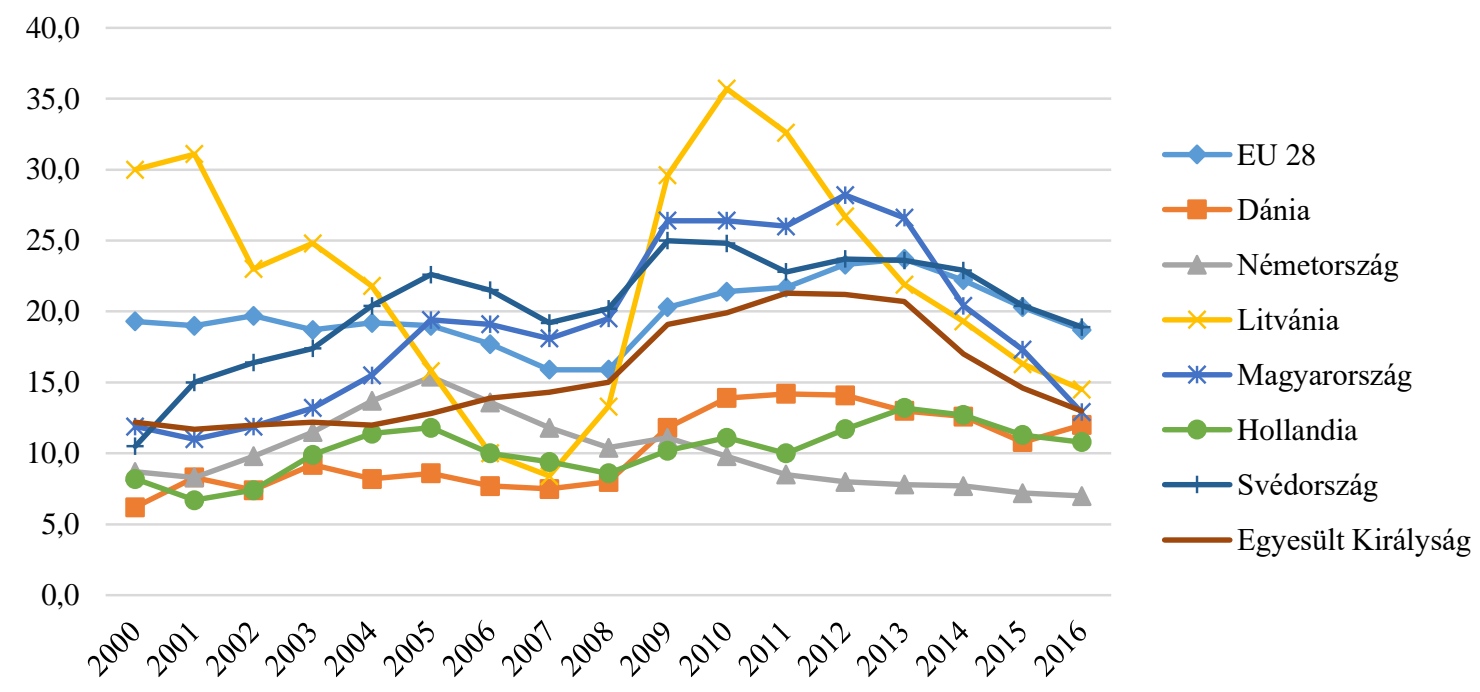

Forrás: Eurostat (2017) adatai alapján saját szerkesztés.

5.4. ábra NEET ráta a kiemelt tagállamokban (15-24 évesek; 2004-2016; \%)

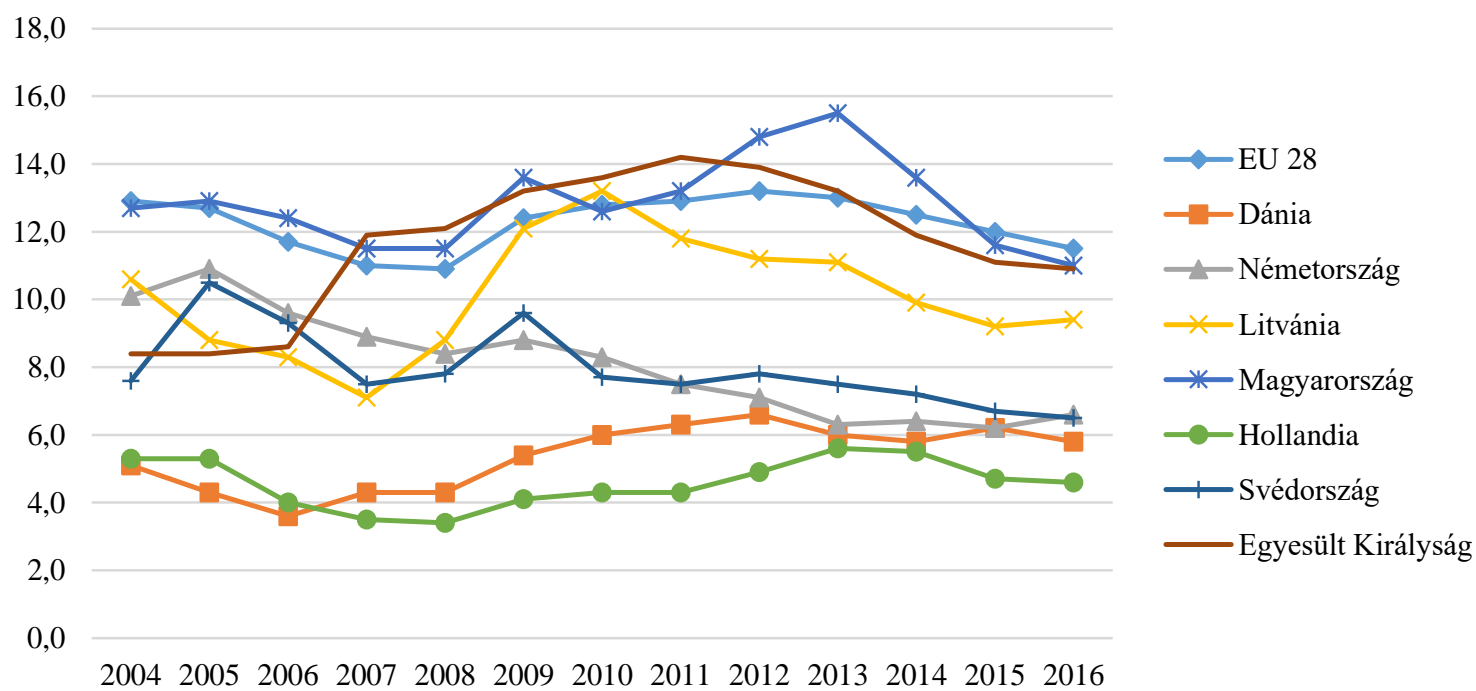

Forrás: Eurostat (2017) adatai alapján saját szerkesztés.

Cinalli és Giugni (2013) cikkükben az európai ifjúsági munkanélküliségi rendszerek (youth unemployment regimes) meghatározásával foglalkoznak. Ezek alatt azon egységes eszközök és politikák készleteit értik, melyeket az államok a munkanélküliség, azon belül is az ifjúsági munkanélküliség csökkentésére alkalmaznak. Két dimenzió, a munkanélküliségi szabályozás (unemployment regulations) és a munkaerőpiaci szabályozás (labour market regulations) mentén vizsgálták ezeket az állami intézkedéseket, összesen hét országban. Ezek alapján az ifjúsági munkanélküliségi rendszerek alábbi négy típusát különítik el: 
1. rugalmas munkapiac jellemzi inkluzív munkanélküliségi szabályokkal a flexicurity (rugalmas és biztonságos) vagy szociális védelem (social protection) modelljét (Svédország, Svájc és Franciaország tartozik ide);

2. szintén rugalmas munkapiac, de emellett a munkanélküliek kizárása jellemzi a bizonytalanság (precariousness) modelljét (Németországot és Lengyelországot ide sorolják);

3. merev munkaerőpiaci szabályozás él az exkluzív gazdasági védelem (economic protection) modelljében (Olaszország és Portugália) és

4. az inkluzív teljes védelem (full protection) modellekben.

Mindez jól bizonyítja, hogy a különböző tagállamok más-más megközelítéssel élnek ugyanazon probléma kezelése során. A továbbiakban ismertetünk néhányat a hét kiemelt tagállam által alkalmazott speciális eszközök közül - a legjobb gyakorlatokat -, melyekkel az ifjúsági munkanélküliséget próbálják csökkenteni.

\subsubsection{HolLANDiA}

2013-ban (a válság munkapiaci tekintetben vett mélypontján) Hollandiában az ifjúsági munkanélküliségi ráta 13,2 százalék volt, több, mint 10 százalékponttal alacsonyabb az EU 28 átlagánál (23,7\%). A hosszú távú (legalább 12 hónapig tartó) ifjúsági munkanélküliségi ráta a 15-24 éves korosztályban 2,2 százalék volt, ami az EU 28 országának 8,0 százalékos értékéhez képest igen alacsony. Mindez annak köszönhető, hogy az 1990-es években erősen lecsökkent az ifjúsági munkanélküliség az országban. Ebben az időszakban a holland központi kormányzat három fontos eszközt dolgozott ki annak érdekében, hogy támogatott munkahelyeket hozzanak létre a fiatal munkavállalók számára az állami szektorban (Meijers-Te Riele, 2004):

- a job-pool (1991) a kormányzati szektorban kínál állást a fiatalok számára;

- az ifjúsági garancia törvény (Youth Guarantee Act 1992) a szociális ellátások kiváltása érdekében született, és egy hat hónapig tartó állást garantál minden olyan 21 év alatti (a továbbtanulók esetében 23 év alatti) fiatal személy számára, aki legalább hat hónapja regisztrált munkanélküli;

- a tartósan munkanélküliek foglalkoztatására kidolgozott rendszer (Scheme for additional employment for the long-term unemployed, 1995) az egy évnél hosszabb ideje állástalanok számára teremt munkahelyeket - alapvetően az egészségügyi szolgáltatás, az oktatás és a környezetvédelem területén.

A holland siker legfontosabb faktora, hogy minden társadalmi fél együttesen tesz erőfeszítéseket az állásteremtés érdekében, ami helyi szinten is érvényesül, miközben a 
kormányzat biztosítja a folyamatosságot és koherenciát minden érintett résztvevő számára (CDPS, 2001; Meijers-Te Riele, 2004).

A holland munkaerőpiac - mint már említettük - a flexicurity, vagyis a rugalmas biztonság modellje szerint müködik, amelynek jellemzője a rugalmasság, amely kiegészül a munkavállalók védelmével kapcsolatos erős szabályozással (EPL) (Crowley et al. 2013). Kifejezetten magas a részmunkaidős és határozott idejű munkaszerződések száma a fiatalok körében, ami magas ifjúsági foglalkoztatottságot eredményez - Hollandia e tekintetben az OECD-országok körében az elsők között szerepel. Az OECD.Stat (2016) adatai szerint 2014ben a 15-24 éves foglalkoztatottak 55,5 százaléka határozott idejü állásban dolgozott, ami jelentősen meghaladja az EU tagállamok átlagának 43,3 százalékos értékét. Bár a határozott idejü szerződések bizonytalanabb foglalkoztatást jelentenek, mégis pozitívum a munkavállaló szemszögéből, hogy gyakran határozatlan idejü szerződésekhez vezetnek, valamint, hogy segítenek a humán tőke és a társadalmi/szociális kapcsolatok fejlesztésében. 2015-ben a 15-24 éves hollandiai foglalkoztatottak 71,5 százaléka dolgozott részmunkaidőben, ami a csaknem az EU 28 átlagának $(28,7 \%)$ 2,5-szerese és az OECD átlagnak (30,8\%) is több, mint kétszerese. Eközben Hollandiában a nem önkéntes 15-24 éves részmunkaidős foglalkoztatottak aránya az összes 15-24 éves részmunkaidős foglalkoztatottakon belül 9,8 százalék volt, ami igen alacsonynak tekinthető az EU 28 (26,8\%) vagy akár az OECD átlagával $(15,4 \%)$ összevetve is (5.2. táblázat; OECD.Stat 2016).

5.2. táblázat A részmunkaidős foglalkoztatottak aránya az EU egyes országaiban $(2015 ; \%)$

\begin{tabular}{lcccc}
\hline & $\begin{array}{c}\text { Részmunkaidősök aránya az összes } \\
\text { foglalkoztatotton belül }\end{array}$ & \multicolumn{2}{c}{$\begin{array}{c}\text { Nem önkéntes részmunkaidősök } \\
\text { aránya a részmunkaidős } \\
\text { foglalkoztatottakon belül }\end{array}$} \\
\hline & $\mathbf{1 5 - 2 4}$ évesek & Teljes népesség & $\mathbf{1 5 - 2 4}$ évesek & Teljes népesség \\
\hline EU 28 & 28,7 & 17,2 & 26,8 & 26,8 \\
\hline Dánia & 63,9 & 20,0 & 8,2 & 15,1 \\
\hline Egyesült Kir. & 35,2 & 24,0 & 22,1 & 15,9 \\
\hline Hollandia & 71,5 & 38,5 & 9,8 & 11,7 \\
\hline Litvánia & 10,0 & 7,9 & 10,9 & 29,4 \\
\hline Magyarország & 5,3 & 4,4 & 45,1 & 34,7 \\
\hline Németország & 21,6 & 22,4 & 10,0 & 12,8 \\
\hline Svédország & 38,1 & 14,1 & 47,8 & 30,8 \\
\hline
\end{tabular}

Forrás: OECD.Stat (2016) adatai alapján saját szerkesztés.

A részmunkaidős (és más, nem szabványos) munkaszerződések lehetséges negatív következményeinek mérséklése, valamint a foglalkoztatottak biztonságának garantálása érdekében a munkavállalók védelmével kapcsolatos szabályozás, a bérgarancia rendszer és a kiegészítő nyugdíjak mind nagy jelentőséggel bírnak. 


\subsubsection{NÉMETORSZÁG}

Németországban a 25 év alatti korosztályban a munkanélküliségi ráta a válság előtt és a válság után is az uniós (28 ország) átlag alatti volt, sőt, a válság alatt egyedülálló módon jelentősen csökkent is: a 2007-es 11,8 százalékról 2013-ra 7,8 százalékra, majd 2016-ra 7,0 százalékra (5.3. ábra). A (korosztályos) foglalkoztatási ráták is kifejezetten kedvezőek európai összehasonlításban (5.1. ábra).

Ennek a sikernek a kulcsa az, hogy Németországban hagyományosan igyekeznek összekapcsolni az oktatást a munkavégzéssel, például szakmai gyakorlati programok, ösztöndíjak és a tanulás melletti (akár alkalmi) munkavégzés támogatásával, hiszen ezeknek nagy jelentősége van a tanulás és a munka közötti átmenet megkönnyítésében (HughesBorbély-Pecze, 2013). Az országban müködő - rendkívül sikeres - duális gyakornoki rendszer ötvözi a munkatapasztalatot és a munkahelyi képzést a hagyományos tantermi oktatással (Cahuc et al., 2013; Solga et al., 2014). Minden gazdasági szektorban ösztönzik a munkáltatókat, hogy alkalmazzanak pályakezdő fiatalokat, illetve biztosítsanak számukra szakmai gyakorlati státuszt. A munkahelyi képzés költségeit a cégek állják, cserébe 4-5 évig számolhatnak az általánosnál alacsonyabb bérért dolgozó fiatal munkaerővel. ${ }^{53}$

A német foglalkoztatási szolgálat emellett egy olyan rendszert állított fel, amelyben speciális ifjúsági tanácsadók dolgoznak, és egy tanácsadó egyszerre legfeljebb 75 NEET fiatallal dolgozik, segíti őket a számukra megfelelő munka kiválasztásában, áthidaló programokkal és tanácsadással. A Pályaorientációs Program képzések és szakmai gyakorlat biztosítása révén segíti a fiatalok pályaválasztását (Borbély-Pecze-Hutchinson, 2013; HughesBorbély-Pecze, 2013). Megemlítendő továbbá a „Minijobs” (Nebenjobs)-rendszer ${ }^{54}$, amelyet a Hartz-reformok (2003-2005) keretében vezettek be, és amely hozzájárult a fiatalok foglalkoztatásához is. A minijob vagy miniállás olyan részmunkaidős állásokat jelent, amelyekkel járó havi fizetés nem haladja meg a 450 eurót, vagy rövid ideig tart a foglalkoztatás. Előnye, hogy a foglalkoztatónak csökkentett mértékü járulékot kell fizetnie az alkalmazott után (míg az állam biztosítja az egészség- és társadalombiztosítást), és az alkalmazottaknak nincs

${ }^{53}$ A gyakorlati képzés oktatási rendszerbe történő integrálásának hatása mindamellett sokrétü. Tény, hogy a gyakorlati programok alatt megszerzett szakmai tapasztalat segítheti az elhelyezkedést a munkaeröpiacon, de ha ez az általános elméleti, közismereti tárgyak és az ezekhez szükséges készségek elsajátításának rovására történik, akkor a fiatalok elesnek a kognitív képességeik fejlesztésének lehetőségétől, amikor a leginkább fogékonyak lennének rá. Ez hosszabb távon ronthatja a szakmai előrelépési esélyüket és társadalmi szinten is veszteséget jelent. Másrészt ez a fajta iskolarendszerbe integrált gyakorlati képzés a vállalatok számára kedvező, hiszen a betanítás költségei így részben vagy egészben áthárulnak az államra - végső soron pedig az adófizetőkre.

www.minijob-zentrale.de, www.nebenjob.de/ratgeber_nebenjobs/hartz-4-nebenverdienst.html, www.angloinfo.com/how-to/germany/working/employment/mini-jobs,

https://entwickler.de/online/webmagazin/minijobs-what-are-they-and-what-do-i-need-to-know-1260.html 
jövedelemadó-fizetési kötelezettségük. Hátránya, hogy nehéz kitörni belőle, a miniállások ritkán válnak hagyományos állásokká. 2014-ben hozzávetőleg 7,5 millió német dolgozott ilyen miniállásban - legtöbb esetben kizárólagosan, de néha fóállás mellett. A minijob jellegü állások elsősorban a kereskedelmi szektorban és a háztartási munkák esetében jelennek meg. (Korábban ezek mellett az is segítette a pályakezdők elhelyezkedését az országban, hogy 2015ig nem volt nemzeti szinten meghatározott minimálbér - noha ágazati és területi minimumok akkor is léteztek [Cahuc et al., 2013].)

\subsubsection{DÁNIA}

Dánia a munkanélküliség alakulása szempontjából szintén egy jól teljesítő ország az EU-ban: 2011-ben 7,6 százalékon tetőzött, 2016-ban pedig 6,2 százalék volt a munkanélküliségi ráta (Eurostat, 2017). A fiatalok között is relatíve alacsony a munkanélküliségi ráta (2015-ben 10,8\%, 2016-ban 12,0\%), s ez a válságot megelőzőleg is igaz volt (2007-ben 7,5\%). Jensen et al. (2003) szerint ez a teljesítmény egy 1996-ban bevezetett radikális munkaerőpiaci reformnak (Youth Unemployment Programme, YUP) köszönhető, mivel ez kifejezetten az alacsony iskolázottságú fiatal munkanélkülieket célozta meg. Az Eurostat (2017) adatai szerint a 1990es évek elején 10-13 százalék közötti volt a 25 év alattiak munkanélküliségi rátája, de a reformot követően lecsökkent: a 2000-es évek elején már 6-9 százalék között mozgott. A YUP egyik fő célja az aktív munkaerőpiaci programok fejlesztése és a munkakeresés időtartamának lerövidítése volt, a másik pedig a fiatalok oktatásban való részvételének ösztönzése. A program lényege, hogy azoknak a legfeljebb középfokú végzettségü 25 év alatti fiataloknak, akik az elmúlt 9 hónapban legalább 6 hónapon keresztül munkanélküliek voltak, felajánlanak egy 18 hónapos speciális szakképzési lehetőséget. Ez idő alatt a munkanélküli ellátásnak csak 50 százalékára jogosult a fiatal, ezért ez arra ösztönzi, hogy a speciális képzés mellett állami ösztöndíjas oktatásban is részt vegyen vagy munkát keressen. A képzésben való részvétel visszautasítása a munkanélküli segély megvonásával jár. Olyan átfogó programról van tehát szó, amely szigorítja a segélyekhez való hozzájutás kritériumait, miközben aktívan támogatja az oktatásban való részvételt (ami a jövőbeli foglalkoztathatóságot növeli), s mindezt ösztönzők és szankciók alkalmazásával éri el (Jensen et al., 2003; Nickell et al., 2005). A YUP eredményessége jól látható az ifjúsági munkanélküliségi ráta csökkenésében, de ezzel párhuzamosan a korosztály foglalkoztatási rátája nem növekedett, ami azt mutatja, hogy a program (rövid távon) inkább az oktatásban való részvételt erősítette, mint a fiatalok álláshoz jutását. Nickell et al. (2005) abban is látják a YUP erényét, hogy általa inflációs nyomás gerjesztése nélkül sikerült lecsökkenteni a munkanélküliséget. 
Dániában egyébként hagyományosan magas az aktív munkaerőpiaci politikai eszközökre fordított közösségi kiadások összege: GDP-arányosan a legmagasabb az Európai Unióban (2000-ben 1,69\%, 2015-ben 1,46\% volt) (Eurostat, 2017; Mploy, 2011; 5.5. ábra). Ennek azért is van jelentősége, mert az aktív munkaerőpiaci politikai eszközök célzott és megfelelő alkalmazásával a hosszú távú munkanélküliség csökkenthető és javítható a munkaerőpiac hatékonysága (Duell, 2012). Ehhez hozzátartozik, hogy a közösségi kiadások több mint fele helyi önkormányzati szinten jelenik meg, ami a helyi foglalkoztatáspolitika jelentőségét is mutatja (Mploy, 2011). Ez azért is pozitívum, mert így lehetőség van kifejezetten a lokális (és regionális) jellemzőknek megfelelö politikai eszközök kialakítására - hiszen vannak olyan területek, városok, ahol az alacsony iskolai végzettség jelent nagyobb problémát, míg máshol a munkakereslethez igazodó szakképzettségü munkavállalókból van hiány. Ráadásul az a tény is ismert, hogy sok országban jelentős eltérés mutatkozik a (teljes és az ifjúsági) munkanélküliség mértékét illetően a régiók között. 2009 óta pedig minden munkavállalókat és vállalatokat érintő foglalkoztatással kapcsolatos feladat (munkaügyi központok müködtetése, képzések szervezése, együttmüködés más hivatalokkal és munkáltatókkal, munkanélküli segélyek folyósítása, stb.) önkormányzati szinten valósul meg, ami rugalmas munkaerőpiacot eredményez, úgy, hogy közben nemzeti szinten érvényesül az átláthatóság (Mploy, 2011). Mindez természetesen a fiatalok munkapiaci kilátásaira is kedvező hatással bír.

5.5. ábra Az aktív munkaeröpiaci politikai eszközökre fordított kiadások a GDP arányában a kiemelt tagállamokban (2005-2015; \%)

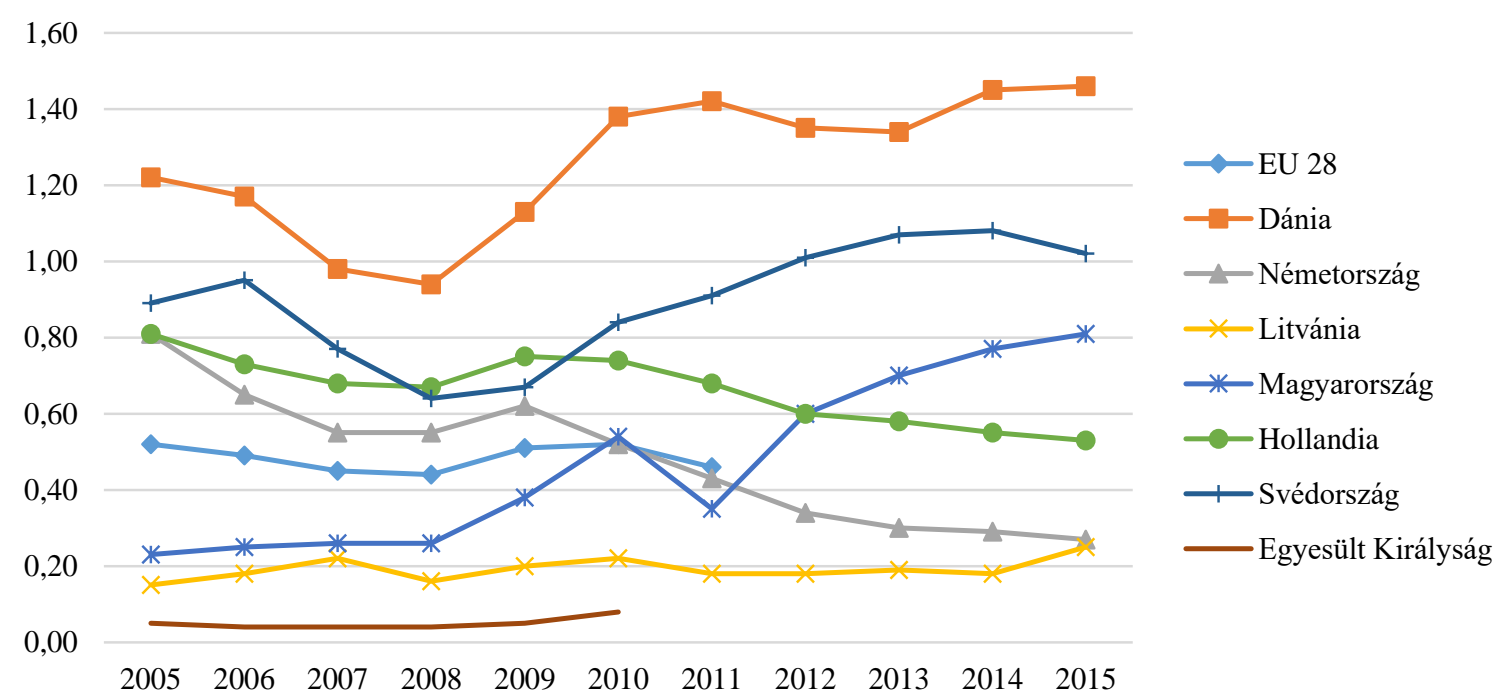

Forrás: Eurostat (2017) adatai alapján saját szerkesztés.

Dániában a szakmunkásképzés meglehetősen népszerü, a kötelező iskolai képzést elvégzettek 35 százaléka vesz benne részt (Lindahl, 2011). Így nem meglepő, hogy 
Németországhoz hasonlóan Dániában is szerepe van a szakmai gyakorlati programok és a tanulás melletti munkavégzés támogatásának. Emellett a korai iskolaelhagyó (15-17 éves) fiatalokkal együttmüködve az ifjúsági tanácsadó központok kötelesek személyre szóló oktatási tervet készíteni, és ellenőrizni annak követését egészen a fiatalok 18 éves koráig (BorbélyPecze-Hutchinson, 2013).

A 2007-2008-as válság Dániában is a munkanélküliség növekedéséhez vezetett, de így is viszonylag alacsony maradt, bár még mindig magasabb a válság előtti 7,5 százaléknál (5.3. ábra). A fiatalok közötti munkanélküliség visszafogására az Ifjúsági és Oktatási Minisztérium a fiatalok számára karrier-tanácsadást nyújt, a kormány pedig pénzügyi támogatást biztosít a meglévő szakmai gyakorlati helyek fenntartására és újabbak létrehozására, mivel ezek száma csökkent a válság alatt (Hughes-Borbély-Pecze, 2013).

\subsubsection{EgYesÜlt KiRÁLysÁG}

Az Egyesült Királyság és Litvánia esetében az ifjúsági munkanélküliségi ráták már közelítenek az uniós átlaghoz (2016-ban rendre 13,0\% és 14,5\%) (5.3. ábra). Ám míg Litvániában ez az uniós átlagnál alacsonyabb ifjúsági foglalkoztatással (2016-ban 30,2\%) párosul, addig az Egyesült Királyságban viszonylag magas az ifjúsági foglalkoztatási ráta (2016-ban 50,9\%) (5.1. ábra). Biggins (2012) ezt az Egyesült Királyságot jellemző kedvező értéket elsősorban két (válság előtti, az 1990-es évek végén született) kezdeményezés eredményének tulajdonítja. Ezek a New Deal for Young People (NDYP) és a Future Jobs Fund (FJF). Az NDYP a munkanélküli fiataloknak szóló karrier-tanácsadás mellett képzési programokat biztosított, melyeket különböző feltételekhez kötött, és ha összesen 10 hónap alatt sem talált állást egy résztvevő fiatal, akkor vagy teljes idejü oktatást vagy munkalehetőséget kínált 12 hónapra (eszerint ez is egy ifjúsági garanciaprogramnak tekinthető). A program rövid távon rendkívül eredményesnek bizonyult. Az FJF más megközelítést alkalmazott, ennek célja a munkaerőpiaci tapasztalat biztosítása a fél évnél hosszabb ideje munkanélküli fiataloknak, amit a nemzeti bérminimum ellenében végzett közösségi munkával szerezhettek meg. A programmal szemben több kritika is megfogalmazódott, mivel bár sok munkahelyet teremtett, mégsem volt elég hatékony.

Az Egyesült Királyságban komoly problémát jelent a hátrányos helyzetü fiatalok leszakadása. Körükben jellemző a korai iskolaelhagyás, és nehezített a munkaerőpiacra való belépésük is. Ennek mérséklése érdekében 2011-ben született egy jótékonysági kezdeményezés, a Speakers for Schools, melynek lényege, hogy a hivatásukban sikeres emberek előadásokat tartanak az állami iskolák és felsőoktatási intézmények diákjai számára, 
így ezek a fiatalok is hozzáférnek karrier-információkhoz és megismernek potenciális példaképeket (Hughes-Borbély-Pecze, 2013). Ez a kezdeményezés jó példája a civil összefogás jelentőségének.

\subsubsection{LITVÁNIA}

Litvániában az ifjúsági munkanélküliség kérdése az ország függetlenségének visszanyerése óta terítéken van (Repečkienè et al., 2012). Az átalakulás, a strukturális reformok és a privatizáció fellendítette a munkanélküliséget minden korosztályban, különösen vidéken (Breen et al., 2003). Az Eurostat (2017) adatai szerint az ezredforduló óta és a válságot megelőzően a 25 év alattiak munkanélküliségi rátája 2001-ben volt a legmagasabb, 31,1 százalék, majd attól kezdve egészen 2007-ig folyamatosan és jelentősen lecsökkent, egészen 8,4 százalékra. A foglalkoztatás növekedése a széles körben alkalmazott aktív munkaerőpiaci politikai eszközöknek köszönhető: ilyen az álláskeresők és a munkáltatók közötti közvetítés, a szakmai képzések és átképzések szervezése, a munkahelyteremtés (például közmunka révén és az önfoglalkoztatás támogatásával), bizonyos célcsoportok foglalkoztatásának további támogatása (Repečkienė et al., 2012).

A válság azonban ismét megugrasztotta a munkanélküliséget, így 2010-ben felugrott 35,7 százalékra az ifjúsági munkanélküliségi ráta, de azóta folyamatosan csökken, és 2013-ban már ismét az EU-s átlag alatti volt (2016-ban 14,5\%) (5.3. ábra). A válság során bevezetett főbb intézkedések a fiatal munkanélküliek támogatására a következők voltak (Repečkienè et al., 2012):

1. a munkapiaci kereslethez igazodó ingyenes szakmai képzések biztosítása;

2. egy adatbázis (The Talent Bank) létrehozása és müködtetése végzős diákok (és frissen végzettek), valamint munkáltatók számára, amely segíti a megfelelő munkahelyek megtalálását;

3. a képzetlen fiatalok számára ideiglenes foglalkoztatás biztosítása a szociális szektorban;

4. kiemelten eredményes intézkedés, hogy pénzügyi támogatást (kedvezményes hitel) nyújtanak a fiatalok számára vállalkozás indításához és az önfoglalkoztatás támogatására;

5. a gyakorlatorientált és a munkaerőpiaci kereslethez igazodó oktatási rendszer kialakítása érdekében szakmai képzéseket és gyakorlati lehetőséget biztosítanak a diákoknak; 
6. a pályakezdő fiatalokat alkalmazó munkáltatók számára alacsonyabb társadalombiztosítási hozzájárulás fizetési kötelezettség, vagyis bértámogatást kapnak.

A gyors javulásban nagy szerepe volt az Európai Bizottságnak, hiszen 2012 februárjában létrejött egy nemzeti és Bizottsági tisztviselőkből álló akciócsapat, amely az uniós támogatások lehívásának felgyorsításán és újraelosztásán dolgozott, hogy támogassa a fiatalok számára a munkahelyek létrejöttét és a KKV-k finanszírozási forrásokhoz jutását (European Commission, 2013). Ennek köszönhetően a strukturális alapok átprogramozásával 31 millió eurót fordíthattak célirányosan a fiatalok foglalkoztatásának segítésére. Így a fent felsorolt programok megvalósulása részben ennek volt köszönhető. Érdemes még kiemelni, hogy a litván kormány nagyon fontosnak tartja a külföldi müködőtőke vonzását. Ennek érdekében igyekszik kedvező jogi és gazdasági környezetet kialakítani a külföldi befektetések számára, elsősorban a szolgáltatási szektorban, a magas képzettségi szintre és a fejlett infrastruktúrára is építve (Kreivys 2010; Mező-Bagi, 2012).

\subsubsection{SVÉDORSZÁG}

Svédországban a teljes munkanélküliségi ráta az Európai Uniós átlagnál alacsonyabb volt a válság elött és 2016-ban is (2007-ben 6,2\%, 2016-ban 7,0\%). Azonban a 25 év alattiak körében mindkét évben meghaladta az EU átlagát néhány százalékponttal (2007-ben 19,2\%, 2016-ban 18,9\%) (5.3. ábra). Az ifjúsági munkanélküliségi arány is itt a legmagasabb a kiemelt tagállamok közül, 2016-ban 10,4 százalék (5.2. ábra). A fiatalok foglalkoztatása viszont kedvező, magasabb az uniós átlagnál (5.1. ábra). Az országban 2007-ben bevezettek egy új ifjúsági garanciaprogramot (job guarantee for young people) a 16-24 éves regisztrált munkanélküli fiatalok számára. (Az első ilyen programot 1984-ben indították el, éppen Svédországban.) A munkanélküliség első három hónapjában az állami foglalkoztatási szolgálatok segítséget nyújtanak a munkanélküli fiatal céljainak értékelésében, és ha ez idő alatt nem talál munkát, akkor további segítséget kap a keresésben és szakmai gyakorlati, képzési/oktatási, illetve vállalkozásindítási lehetőséget kínálnak neki (Eurofound, 2012b). Így megelőzhető a hosszú távú munkanélküliség kialakulása a fiatalok esetében, viszont a program egyik hátránya, hogy a munkapiac strukturális problémáira nem ad megoldást.

Bár két reformcsomag keretében (2007-ben és 2009-ben) csökkentették a fiatal munkavállalók után fizetendő munkáltatói hozzájárulás mértékét, Skedinger (2014) a kiskereskedelmi szektorban folytatott kutatása azzal az eredménnyel zárult, hogy ez az intézkedés valamelyest javított a fiatalok munkaerőpiaci helyzetén, de összességében 
meglehetősen költséges eszköz. Valójában leginkább csak a minimálbéren (vagy ahhoz közel) foglalkoztatottak esetében valósult meg az álláshoz jutás visszafogott mértékü javulása.

További, a munkaerőpiacra való belépést segítő intézkedésnek tekinthető a szakoktatás és szakképzés 2011 őszétől bevezetett reformja, melynek lényege, hogy a gyakorlatorientált munkahelyi tanulás nagyobb súllyal jelenik meg a szakmunkásképzésben (korábban a hároméves képzésből ez csupán 15 hét volt, ettől kezdve viszont a képzési időnek legalább a felét munkahelyi képzéssel kell tölteni). Igaz, ez a reform a szakképzésben résztvevő diákok zömét nem érinti, mert a többségük nem szakmunkásképzést választ (Lindahl, 2011).

\subsubsection{MAGYARORSZÁG}

Noha a válság alatt hazánkban is jelentősen megnövekedett az ifjúsági munkanélküliség, 2013ban már csökkenni kezdett és 2014-ben a 15-24 évesek munkanélküliségi rátája az uniós átlag alatti, 20,4 százalék volt, 2016-ban pedig már 12,9 százalék (5.3. ábra). A fenti országoktól eltérően azonban Magyarországon nem jellemző a duális szakképzés, vagy a tanulás és a munkaerőpiaci jelenlét ilyen mértékủ egyidejüsége, ráadásul a kevés dolgozó diákra is inkább csak a szünidei munkavégzés a jellemző (KSH, 2015). Más szóval, mivel hazánkban jellemzően magas a felsőfokú oktatásban résztvevő fiatalok aránya, a gazdaságilag aktívak száma relatíve alacsony (de az 5.4. ábra azt is mutatja, hogy a NEET ráta relatíve magas), és a dolgozó 15-24 évesek többnyire középfokú végzettségűek. A KSH (2015) adatai szerint a részmunkaidőben dolgozó fiatalok aránya alacsony, 7 százalék körüli, viszont a 25 év alattiak több mint 24 százaléka határozott idejü szerződéssel dolgozott, ami a próbaidőre is visszavezethető. Az is jellemző, hogy a fiatalok inkább hajlandók bejelentés nélkül történő (fekete vagy szürke) munkavégzést is vállalni, mint az idősebbek (ez magyarázhatja a magas NEET rátát).

A fiatalok közül leginkább az alacsonyan képzettek boldogulnak nehezen a munkaerőpiacon. Az alapfokú és szakiskolai végzettségüek alacsony foglalkoztatásának egyik fő oka a hiányos alapkompetenciákra vezethető vissza. Az oktatáspolitikai átalakítás éppen a gyakorlatorientált oktatás fejlesztésére próbál hangsúlyt fektetni, azonban ennek eredménye egyelőre nem látványos, ráadásul megvannak a hátulütői, hiszen a reformintézkedések azzal a veszéllyel fenyegetnek, hogy a fiatalok jelentős részénél tovább súlyosbítják a hiányos alapkészségek problémáját, ami hosszú távon társadalmi szinten is kihívásokat eredményez (Matheika, 2013).

A válság során születtek intézkedések a fiatalok munkaerőpiaci helyzetének javítása érdekében, bár a magyarországi foglalkoztatáspolitikai eszközök többsége nem kifejezetten a 
fiatalokra koncentrál (Matheika, 2013). Az egyik ilyen a Munkahelyvédelmi Akcióterv, ${ }^{55}$ amely több, munkaerőpiaci szempontból hátrányos helyzetü munkavállalói csoport ${ }^{56}$ munkaadói számára nyújt a munkáltatót terhelő szociális hozzájárulási adóból (a bruttó bér 27 százaléka) és szakképzési hozzájárulásból (a bruttó bér 1,5 százaléka) igénybe vehető kedvezményeket. A 25 év alattiakat illetően a törvény két csoportot különít el (NFSZ, 2014): a legfeljebb 180 nap munkaviszonnyal rendelkező pályakezdő munkavállalók részére a foglalkoztatás első két évében a bruttó bér 27 százaléka, de legfeljebb 27 ezer forint az igénybe vehető munkaadói kedvezmény; míg a 180 napnál több munkaviszonnyal rendelkező személy foglalkoztatása esetén a bruttó munkabér 14,5 százaléka, de legfeljebb 14500 forint. Amennyiben a munkáltató a munkavállalója után 27 százalékos szociális hozzájárulási adókedvezményre jogosult és azt érvényesíti is 100 ezer forint bruttó bérig, a szakképzési hozzájárulást sem kell megfizetnie, de szintén csak 100 ezer forint bruttó bérig.

Magyarországnak a hazai források mellett számos Európai Uniós finanszírozású program is rendelkezésére áll a fiatalok munkaerőpiaci integrációjának előmozdítása érdekében. Itt alapvetően bérköltség-támogatásra és képzési támogatásra kell gondolni. Ezek közül kiemelendők a Társadalmi Megújulás Operatív Program ${ }^{57}$ keretében meghirdetett pályázatok a pályakezdők támogatására a konvergencia régiókban és a fiatalok vállalkozóvá válását segítő pályázatok. Hasonlóképpen a Gazdaságfejlesztési és Innovációs Operatív Program $^{58}$ több pályázata keretében a fiatalok vállalkozóvá válását támogatja, valamint gyakornoki foglalkoztatás finanszírozására is lehetősége van pályázni a vállalkozásoknak. A GINOP-5.2.1 ${ }^{59}$ keretében valósul meg a magyar Ifjúsági Garancia program ${ }^{60}$ is, amely megyei szinten határozza meg az alkalmazott programelemeket - ez jó példa arra, hogy az EU az Európai Szociális Alapból származó pénzügyi támogatást nyújt a tagállamoknak az ifjúsági garancia kiépítéséhez. A programelemek lehetnek a képzési költségek, a munkába járáshoz kapcsolódó utazási költségek és a lakhatási költségek támogatása mellett a foglalkoztatóknak juttatott bérköltség támogatás, valamint a vállalkozóvá válás segítése.

55 Az egyes adótörvények és azzal összefüggő egyéb törvények módosításáról szóló 2011. évi CLVI. törvény.

${ }^{56}$ Az akcióterv a fiatalok mellett az 55 év felettiek, a szakképzetlen munkavállalók, a tartósan álláskeresők és a kisgyermekes munkavállalók foglalkoztatása esetén határoz meg kedvezményeket.

57 „A Társadalmi Megújulás Operatív Program átfogó célja a munkaerö-piaci részvétel növelése” (http://eupalyazatiportal.hu/tamop_programleiras/, letöltve: 2016.07.10.).

58 „A 2014-2020-as idöszakra vonatkozó Gazdaságfejlesztési és Innovációs Operatív Program (GINOP) a magyar gazdasági növekedés ösztönzése miatt jött létre. Az operatív program egyik legfontosabb célkitüzése, hogy a magyarországi foglalkoztatási ráta elérje a 75\%-ot” (www.ginop.hu, letöltve: 2016.07.10.).

${ }^{59} \mathrm{http}: / /$ nfsz.munka.hu/engine.aspx?page=GINOP G521

60 A Közép-magyarországi régióban az ifjúsági garanciát azonban a VEKOP-8.2.1-15 projekt biztosítja. 
A harmadik nagyobb intézkedési csoportot a közfoglalkoztatási programok jelentik. Ahogyan Matheika (2013, 16. o.) fogalmaz, e programok ,2007-2008-ban még 60-65 ezer föt érintettek, 2009-ben viszont már 139 ezer fö, 2011-ben pedig több mint 266 ezer fö vett részt valamilyen közfoglalkoztatási eszközben, és ezzel a közfoglalkoztatási programok az összes aktív foglalkoztatáspolitikai programokon belül fölényesen domináns szerephez jutottak. Az Eurostat szerint a fiatalok aránya a résztvevök között megközelítöleg 15\%”. 2014-ben a három típusú közfoglalkoztatási programban már 483 ezer érintett fö vett részt, de mivel egy személy több típusú közfoglalkoztatásban is szerepelhet, ezért közfoglalkoztatásban részt vevő személyek nettó létszáma az egész évre 376 ezer fő volt. A havi átlagos létszám viszont ennél kevesebb volt, 179 ezer fö. ${ }^{61}$ Tekintve, hogy 2014-ben az összes 15-64 éves foglalkoztatott létszáma valamivel 4 millió fő felett állt (Eurostat, 2016), azt mondhatjuk, hogy a foglalkoztatottak hozzávetőleg 4 százaléka dolgozott a közfoglalkoztatási programban. A közfoglalkoztatási programot azonban sok kritika éri, mert bár valóban az alacsony képzettségü, tartósan munkanélküli rétegeket juttatja álláshoz, de nem a magánszektorban, és nem járul hozzá a foglalkoztathatóság javításához (Európai Bizottság, 2016).

Összességében a hazai gyakorlattal kapcsolatban az szürhető le, hogy célzottan alapvetően adócsökkentéssel, emellett pedig különféle (egyedi) Európai Uniós finanszírozású programok segítségével igyekszik támogatni a fiatalok foglalkoztatottságának javítását.

\subsection{A KÖZÖS JELLEMZÖK, JÓ GYAKORLATOK ÖSSZEFOGLALÁSA}

Az áttekintett esetpéldák alapján elmondható, hogy az ifjúsági foglalkoztatottság javításában nagy szerepe van a fiatalokat megcélzó jól megtervezett aktív munkaeröpiaci eszközöknek valamint az oktatási/képzési rendszer és a munkaeröpiac gyakornoki programokkal történő összekapcsolásának. Nagyon fontos tehát a realizált kormányzati kiadások hatékony felhasználása. Ennek érdekében elengedhetetlen a kormányzat és a gazdasági szereplők együttmüködése, illetve még előnyösebb, ha uniós szinten is megvalósul a kooperáció a fiatalok mobilitásának ösztönzésével. Az 5.3. táblázat összefoglalja azokat a lépéseket, amelyek nagyobb jelentőséggel bírtak a fiatalok munkapiaci helyzetének javításában, nem feltétlenül csak a válság időszakában, hanem az ezredforduló óta. (Természetesen az összes típusú intézkedés megjelenik a vizsgált országok mindegyikében, de eltérő súllyal, ezért emeltük ki a legjelentősebb lépéseket.) Látható, hogy ezek között csak egy passzív eszköz (bértámogatás)

61 
van, az információszerzés (karrier-tanácsadás, közvetítés) és képzésekben, oktatásban való részvétel támogatása nagyobb hangsúllyal jelenik meg, és hosszú távon is fenntartható.

5.3. táblázat Jelentősebb munkapiaci politikai lépések a kiemelt tagállamokban

\begin{tabular}{ll}
\hline Kiemelt jelentőségü intézkedések & Alkalmazó országok \\
\hline karrier-tanácsadás & Németország, Dánia, Egyesült Királyság \\
\hline álláskeresők és a munkáltatók közötti közvetítés & Litvánia \\
\hline \multirow{2}{*}{ képzések, oktatási részvétel támogatása } & $\begin{array}{l}\text { Dánia, Németország, Egyesült Királyság, } \\
\text { Litvánia, Svédország, Magyarország }\end{array}$ \\
\hline gyakornoki rendszer, programok & Németország, Dánia, Litvánia, Svédország \\
\hline állás a közszektorban & Hollandia \\
\hline közfoglalkoztatás, közmunka & Egyesült Királyság, Litvánia, Magyarország \\
\hline önfoglalkoztatás támogatása & Litvánia, Svédország, Magyarország \\
\hline \multirow{2}{*}{ ifjúsági garancia } & 2013: Litvánia, Svédország, Magyarország \\
& 2014: Dánia, Hollandia, Egyesült Királyság, \\
\hline bértámogatás & Németország \\
\hline
\end{tabular}

Forrás: saját szerkesztés.

Az aktív munkaerőpiaci politikai eszközök sikerességének kulcsa az OECD (2015) szerint három pilléren nyugszik, ezek pedig: a motiváció, a foglalkoztathatóság és a lehetőség. Ezek megvalósítását pedig hatékony munkaerőpiaci intézmények és politikák segítségével lehet elérni. Az aktiválás során a motiváció erősítése nem minden esetben szükséges, de különösen az elhúzódó sikertelen álláskeresés során figyelhető meg, hogy a munkanélküliek reményvesztetté válnak. Az ő esetükben elengedhetetlen a motiváció erősítése, hogy ne adják fel az álláskeresést. Ám ez nem nem elég a sikerhez, ha az álláskereső kompetenciái nem keresettek a munkaerőpiacon, ezért a legtöbb aktivációs politikai eszköz a foglalkoztathatóság javítására törekszik, például különféle képzésekkel. A lehetőségek megteremtése pedig alapvetően a munkáltatók elérése révén történhet meg, például az alkalmazás költségeinek csökkentésével, vagy pedig a munkavállalás egyéb (például egészségi vagy szociális) akadályainak elhárításával.

$\mathrm{Az}$ is látható, hogy Európában (szükebb értelemben az Európai Unióban) az ifjúsági munkanélküliség olyan akut probléma, amely a foglalkoztathatóságot javító strukturális változtatások mellett a NEET fiatalok számára azonnali támogatást is szükséges biztosítani. Ebből a megfontolásból döntött az összes tagállam is az ifjúsági garanciaprogramok bevezetéséről. E programok nagy előnye, hogy azonnali intézkedéseket követelnek és így elkerülhető a hosszú távú ifjúsági munkanélküliség - és a későbbi kedvezőtlen foglalkoztatási kilátások, a sebhely-hatás - kialakulása.

Emellett úgy tűnik, hogy a relatíve rugalmasabb munkaerőpiacokon, ahol a fiataloknak több lehetőségük van részmunkaidős állást vállalni már a tanulmányaik mellett, jobbak az 
esélyeik. Az 5.4. táblázatból jól látható, hogy Hollandiában és Dániában kiemelkedően magas a részmunkaidőben dolgozó fiatalok aránya. A humán tőke és a társadalmi/szociális kapcsolatok fejlesztését segítő határozott idejű szerződéssel foglalkoztatott fiatalok aránya pedig Svédországban, Németországban és szintén Hollandiában a legmagasabb.

5.4. táblázat A részmunkaidős és határozott idejű szerződéssel dolgozó fiatalok (15-24 évesek) aránya az EU egyes országaiban 2015-ben (\%)

\begin{tabular}{lcc||ccc}
\hline & $\begin{array}{c}\text { Részmunkaidősök } \\
\text { aránya az összes } \\
\text { foglalkoztatotton } \\
\text { belül }\end{array}$ & $\begin{array}{c}\text { Határozott idejü } \\
\text { szerződések aránya } \\
\text { az összes } \\
\text { foglalkoztatotton } \\
\text { belül }\end{array}$ & $\begin{array}{c}\text { Ifjúsági } \\
\text { munka- } \\
\text { nélküliségi } \\
\text { arány }\end{array}$ & $\begin{array}{c}\text { Ifjúsági } \\
\text { munka- } \\
\text { nélküliségi } \\
\text { ráta }\end{array}$ & $\begin{array}{c}\text { Hosszú távú } \\
\text { (min. 12 hó) } \\
\text { ifjúsági munka- } \\
\text { nélküliségi ráta }\end{array}$ \\
\hline EU 28 & 32,1 & 40,5 & 8,4 & 20,3 & 6,5 \\
\hline Dánia & 67,0 & 22,3 & 6,7 & 10,8 & 0,9 \\
\hline Egyesült Kir. & 37,7 & 14,1 & 8,6 & 14,6 & 3,2 \\
\hline Hollandia & 80,0 & 49,0 & 7,7 & 11,3 & 2,0 \\
\hline Litvánia & 11,4 & 6,1 & 5,5 & 16,3 & $4,4 *$ \\
\hline Magyarország & 6,9 & 23,2 & 5,4 & 17,3 & 4,6 \\
\hline Németország & 23,6 & 52,4 & 3,5 & 7,2 & 1,6 \\
\hline Svédország & 49,0 & 54,2 & 11,2 & 20,4 & 1,2 \\
\hline
\end{tabular}

Megjegyzés: a *-gal jelölt érték 2015-ös adat hiányában a 2014-es évre vonatkozik.

Forrás: Eurostat (2016) adatai alapján saját szerkesztés.

Rövid áttekintésünk egyik legfontosabb tanulsága, hogy minél pontosabban sikerül meghatározni a (hátrányos helyzetü) célcsoportokat és azok jellemzőit, annál hatékonyabban kezelhető a probléma - ezt pedig jelentősen segítheti a lokális és regionális szintü megközelítés. Mindazonáltal Eichhorst et al. (2013, 16. o.) úgy vélik, hogy az ifjúsági munkanélküliség válságára valódi megoldást az érintett munkapiacok strukturális reformjai jelenthetnek, azonban ezek a reformok csak késleltetve tudják kifejteni a várt hatást, ezért a jelenleg érintett fiatalokon tulajdonképpen már nem segíthetnek. Azonban a gazdaságok felépülése és az uniós szintü összefogás mégis reményt kelt a továbbiakra nézve. Ez még azokban az országokban is igaz, ahol az aktív munkaerőpiaci politikákra viszonylag kevesebb forrást tudnak fordítani - ha magas a felhasználás hatékonysága.

A következő fejezetben bemutatjuk a munkaerőpiaci rugalmasság dimenziói és az ifjúsági munkanélküliség kapcsolatára vonatkozó empirikus vizsgálatunk módszertanát és eredményeit. 


\section{A MUNKAERŐPIACI RUGALMASSÁG FIATALOK MUNKAERÖPIACI HELYZETÉRE}

GYAKOROLT HATÁSÁNAK EMPIRIKUS VIZSGÁLATA

Ahogyan az előző fejezetekben bemutattuk, a fiatalok munkanélküliségéhez vezető okok egy része speciális abban az értelemben, hogy az idősebb korcsoportok tagjai nem szembesülnek hasonló nehézségekkel. Azt is láttuk, hogy a szakirodalomban még napjainkra sem alakult ki egységes álláspont arra vonatkozóan, hogy rugalmas vagy rugalmatlan munkaerőpiaci jellemzők szükségesek az általános foglalkoztatási mutatók javulása érdekében. Emellett az 5.2. alfejezetben ismertetett tagállami gyakorlatok is mutatják, hogy az EU tagállamai között is jelentős különbségek vannak mind a rugalmasság mértéke, mind a foglalkoztatás nagysága tekintetében. Ezért érdemes empirikusan megvizsgálni, hogy különbözik-e a munkaerőpiaci rugalmasság fiatalokra és az idősebb munkavállalókra gyakorolt hatása, valamint, hogy a munkaerőpiaci rugalmasság mely dimenziói azok, amelyek kifejezetten a fiatalok foglalkoztatását segítik. $^{62}$ A vizsgált korcsoportok közötti különbségeket összevetve feltárhatóvá válnak a rugalmasság esetleges generációspecifikus hatásai. Empirikus vizsgálatunkban tehát az alábbi kérdésekre kerestük a választ:

1. Mutatkozik-e egyértelmü összefüggés a munkapiaci rugalmasság és a fiatalok (a 1524 évesek) körében tapasztalható munkanélküliség nagysága között az Európai Unió országaiban? (Tehát a dolgozat első hipotézisét: ,, Az Európai Unió tagállamaiban a nagyobb rugalmasságú munkaerőpiacokon magasabb a fiatalok foglalkoztatottsága” teszteljük.)

2. Mennyiben tér el a munkapiaci rugalmasság ifjúsági munkanélküliségre gyakorolt hatása a teljes vagy az idősebb munkavállalók körében jelentkező munkanélküliségre kifejtett hatásától? (Tehát a dolgozat második hipotézisének helytállóságát teszteljük, amely így szólt: „Az Európai Unió tagállamaiban tetten érhető a munkaeröpiaci rugalmasság generációspecifikus hatása, vagyis a fiatal és az idösebb korosztály foglalkoztatottságát eltérö mértékben befolyásolják a rugalmasság különbözö dimenziói. ”)

3. Van-e egyértelmü kapcsolat az Európai Unió tagállamaiban az ifjúsági munkanélküliség nagysága és a munkaerőpiaci politikákra fordított állami

${ }^{62}$ Visszautalunk a korábban említett hasonló célkitűzésű vizsgálatokra. Breen (2005) 27 OECD országot felölelő (1990-es évekbeli adatokat használó) vizsgálata során igazolta, hogy az erősen szabályozott munkaerőpiacokon magasabb az ifjúsági munkanélküliség. Sachs és Smolny (2015) tanulmányukban 17 OECD ország 1982-2005 közötti adatait alapul véve vonták le azt a következtetést, hogy míg a foglalkoztatottak védelmére vonatkozó jogszabályok a fiatalok körében jelentősen növelték a munkanélküliséget, addig az idősebb korosztályt tekintve nem mutatkozott szignifikáns kapcsolat. 
költségvetési kiadások összege között? (A dolgozat harmadik hipotézise: „Az Európai Unió tagállamaiban az ifjúsági munkanélküliség nagysága és a munkaeröpiaci politikákra fordított állami költségvetési kiadások összege között nincs egyértelmü kapcsolat.")

\subsection{A VIZSGÁLT ORSZÁGOK KÖRE ÉS A HASZNÁLT INDIKÁTOROK}

Az elemzés alapsokaságát az Európai Unió 28 tagállama képezi, a vizsgálat időszaka a 20002015 közötti 16 év. Az adatok forrása az Eurostat (2017) és az OECD.Stat (2017) adatbázisa.

$\mathrm{Az}$ alkalmazott indikátorokat a 6.1. táblázat ismerteti. Az ifjúsági foglalkoztatáshoz kapcsolódóan több mutatót is bevontuk az elemzésbe. Ennek oka, hogy ezek az indikátorok az ifjúsági munkanélküliség más-más szegmensét jelenítik meg, így véleményünk szerint jobban meg lehet ragadni a jelenséget, ha több mutatót figyelembe veszünk.

A munkaerőpiaci rugalmasság mértékét leíró indikátorok kiválasztásakor törekedtünk arra, hogy minél többféle mutatót bevonjunk az elemzésbe, hiszen a szakirodalmi elemzésünk egyik fontos tanulsága, hogy a munkaerőpiaci rugalmasság minden dimenziója hatással lehet a munkapiaci kimenetekre. Ennek megfelelően a 3.2. alfejezetben ismertetett indikátorokat alkalmaztuk. Ezekkel kapcsolatban megjegyezzük, hogy a mobilitás dimenzióján belül a munkavállalók védelmével kapcsolatos szabályok (EPL) mindkét (hagyományos és határozott munkaidejü szerződésekre vonatkozó, az elbocsátással szembeni védelmet kifejező) mutatójára igaz, hogy az olyan index, amely 0-6 közötti értékeket vehet fel, ahol a magasabb érték szigorúbb szabályozást jelent. ${ }^{63}$ A GDP-arányos munkaerőpiaci politikákra fordított kiadásokat két csoportra osztva vizsgáltuk: az aktív munkaerőpiaci politikákra (képzés, foglalkoztatási ösztönzők, támogatott foglalkoztatás és rehabilitáció, közvetlen munkahelyteremtés, vállalkozásindítási hajlandóság ösztönzése) fordított kiadásokat, valamint a passzív politikákra fordított kiadásokat (szociális támogatások, segélyek) is.

Végül a makrogazdasági környezet dimenzióját a két kézenfekvő mutató, az egy főre jutó bruttó hazai termék és a GDP-növekedés mellett a fogyasztóiár-index segítségével ragadtuk meg. Hacsak ilyen részlegesen is, de mindenképpen szükségesnek tartottuk a makrogazdaság szerepének elemzését, hiszen ahogyan korábban is láttuk, a gazdasági helyzet meghatározó a foglalkoztatás alakulásában (így a fiatalok foglalkoztatásának alakulásában is).

${ }^{63} \mathrm{http}: / /$ www.oecd.org/els/emp/EPL-Methodology.pdf 
6.1. táblázat A vizsgálat dimenziói és indikátorai (és azok forrásai)

\section{Munkaerőpiaci kimenetek}

\begin{tabular}{|c|c|c|c|}
\hline \multirow{4}{*}{ Fiatalok } & ifjúsági (15-24 évesek) foglalkoztatási ráta (\%) & youth_emp_rate & $O E C D$ \\
\hline & ifjúsági (15-24 évesek) munkanélküliségi ráta (\%) & youth_unemp_rate & $O E C D$ \\
\hline & ifjúsági (15-24 évesek) munkanélküliségi arány (\%) & youth_unemp_ratio & Eurostat \\
\hline & NEET (15-24 évesek) ráta (\%) & NEET_rate & Eurostat \\
\hline \multirow{2}{*}{ Teljes munkaerö } & teljes foglalkoztatási ráta $(\%)$ & total_emp_rate & $O E C D$ \\
\hline & teljes munkanélküliségi ráta $(\%)$ & total_unemp_rate & $O E C D$ \\
\hline \multirow{2}{*}{ Felnőttek } & 25-54 évesek foglalkoztatási rátája (\%) & adult_emp_rate & $O E C D$ \\
\hline & 25-54 évesek munkanélküliségi rátája (\%) & adult_unemp_rate & $O E C D$ \\
\hline \multirow{2}{*}{ Idősebbek } & 55-64 évesek foglalkoztatási rátája (\%) & old_emp_rate & $O E C D$ \\
\hline & 55-64 évesek munkanélküliségi rátája (\%) & old_unemp_rate & $O E C D$ \\
\hline \multicolumn{4}{|c|}{ Munkaerőpiaci rugalmasság } \\
\hline \multirow{3}{*}{ Bérrugalmasság } & reál minimálbér átlagkeresethez viszonyított aránya (\%) & min_wage & $O E C D$ \\
\hline & adóék $(\%)$ & tax_wedge & Eurostat \\
\hline & szakszervezeti szervezettség szintje (\%) & trade_union_dens & $O E C D$ \\
\hline \multirow{4}{*}{$\begin{array}{l}\text { Munkaidő } \\
\text { rugalmassága }\end{array}$} & részmunkaidősök aránya az összes foglalkoztatotton belül (\%) & part_timers & $O E C D$ \\
\hline & nem önkéntesen részmunkaidőben dolgozók aránya a részmunkaidős foglalkoztatottakon belül (\%) & involuntary_part_timers & $O E C D$ \\
\hline & átlagos heti munkaórák száma a föállásban (óra) & hours_worked & $O E C D$ \\
\hline & határozott idejü munkaszerződéssel dolgozók összes alkalmazotton belüli aránya (\%) & temporary_emp & $O E C D$ \\
\hline \multirow{4}{*}{ Mobilitás } & munkavállalók védelmével kapcsolatos szabályok (határozatlan idejű szerződések) (index) & EPL_regular & $O E C D$ \\
\hline & munkavállalók védelmével kapcsolatos szabályok (határozott idejű szerződések) (index) & EPL_temporary & $O E C D$ \\
\hline & aktív munkaerőpiaci politikai kiadások (2-7 kategória) GDP-n belüli aránya (\%) & ALMP_expend & Eurostat \\
\hline & passzív munkaerőpiaci politikai kiadások (8-9 kategória) GDP-n belüli aránya (\%) & PLMP_expend & Eurostat \\
\hline \multicolumn{4}{|c|}{ Makrogazdasági környezet } \\
\hline & egy före jutó GDP (euro) & GDP_per_cap & Eurostat \\
\hline & GDP-növekedés (láncindexált volumenek, 2010=100) & GDP_growth & Eurostat \\
\hline & fogyasztóiár-index (2005=100) & $\mathrm{HICP}$ & Eurostat \\
\hline
\end{tabular}

Forrás: saját szerkesztés. 


\subsection{MÓDSZERTANI HÁTTÉR}

Tekintettel arra, hogy oksági következtetéseket kívántunk levonni, a vizsgálathoz panel regressziót alkalmaztunk, amely felfogható keresztmetszeti idősorelemzésként, ahol ugyanazokról az országokról több időpontban végezzük el a megfigyelést (Tarnóczi et al., 2015). Ezen belül a rögzített hatások modelljét ${ }^{64}$ (fixed effects model) használtuk, amely alkalmas arra, hogy meghatározzuk, hogy a független változók (mint a munkapiaci rugalmasság indikátorai) milyen hatással vannak a függő változó (például az ifjúsági foglalkoztatási ráta) alakulására. „A fix hatások (FE) modelljének alapfeltételezése, hogy a változók különböznek egymáshoz képest, de időben állandóak. Az együtthatók becslése a legkisebb négyzetek módszerével ${ }^{65}$ történik” (Kiss, 2017, 104. o.). A rögzített hatások modelljének függvénye (Kiss, 2017; Park, 2011):

$$
y_{i t}=\alpha+\beta^{\prime} X_{i t}+u_{i}+\varepsilon_{i t} \quad \mathrm{i}=1, \ldots, \mathrm{n} \quad \mathrm{t}=1, \ldots, \mathrm{T}, \quad \text { ahol }
$$

$y_{i}$ a függő változó

$X_{i}$ a magyarázó változó

$\alpha \quad$ a függvény konstans tagja

$\beta_{i}$ a regressziós együttható

$u_{i}$ az egyéni hatás, vagy nem megfigyelhető változó (a különböző megfigyelési egységekre eltérő, időben állandó)

$\varepsilon_{i t}$ a hibatag (idioszinkratikus hiba, amely mind a különböző megfigyelési egységekre, mind időben eltérő)

i a megfigyelési egység (esetünkben ország, $n=28$ )

$\mathrm{t} \quad$ az idő (esetünkben $\mathrm{T}=16$, illetve $\mathrm{T}=8$ ).

A modell követelményei (Álvarez et al., 2017; Kiss, 2017; Park, 2011; Wooldridge, 2010):

- stacioner bemenet ${ }^{66}$ (az Im, Pesaran and Shin (IPS) teszt alapján teljesül, mivel p értékei 0,05 alattiak);

${ }^{64}$ A panel regresszió másik modellje a véletlenhatás modell. A két modell közötti választást a Hausman teszt segíti. Mivel nem volt pozitív definit mátrixa a magyarázó változóknak, ezért nem választhattuk a véletlenhatás modelljét.

${ }_{65}$, „A legkisebb négyzetek módszere (LNM) úgy határozza meg a paramétereket, hogy a tényleges és a becsült paraméterrel illesztett modellek négyzetes eltérése, azaz az eltérések négyzetösszege minimális legyen. [...] Az összes lineáris becslöfüggvény közül itt a legkisebbek a becslések standard hibái. S ehhez még azt sem kell feltételezni, hogy az Y [függö] változó normális eloszlást követ”"(Sajtos-Mitev, 2007, 215-216. o.).

${ }^{66}$ Ebben az esetben elegendőnek tekinthető a gyenge stacionaritás megvalósulása. ,Kovariancia (gyenge) stacionaritásról beszélhetünk abban az esetben, amennyiben az idösor elsö és a második momentuma explicit módon nem függ az idötöl. Tehát $E(x t)=\mu t$ minden $t \in T$ esetre, illetve $E[(x t-\mu t)(x t-m-\mu t)]=\gamma t$ minden $t \in T$ illetve t-hET esetre" (Kiss, 2017, 35. o.). 
- a hibatagok nem autokorreláltak, vagyis egymástól függetlenek (a Durbin-Watsonmutató értéke 2-höz közelít).

A panel regresszió lefuttatásához a Gretl ${ }^{67}$ programot használtuk. Az egyes országok és/vagy vizsgálati évek esetében fellépő adathiányt (9,89\%) imputációs eljárással kezeltük (Oravecz, 2008; Sávai-Kiss, 2016; Udvari et al., 2016). Ehhez a MATLAB programot használtuk.

A vizsgálatban használt modellek függő változóit a munkapiaci kimenetek tíz indikátora képezi, a magyarázó változók a rugalmasság és a makrogazdasági környezet indikátorai (6.1. táblázat). Tekintettel arra, hogy a 2007-2008-as válság rendkívül erős hatást gyakorolt a munkaerőpiaci kimenetekre, úgy véltük, hogy célszerü a 2000-2015-ig tartó 16 éves időszakot egyben és kettébontva is vizsgálni. Így összesen három időszakra futtattuk le a regressziós vizsgálatokat: a teljes időszakra (2000-2015), a válság előtti évekre (2000-2007), valamint a válság alatti (és utáni) évekre (2008-2015). A használt becslőfüggvény általános alakja:

$$
y_{i t}=\alpha+\beta^{\prime} X_{i t}+\beta y_{i(t-1)}+u_{i}+\varepsilon_{i t} \quad \mathrm{i}=1, \ldots, 28 \quad \mathrm{t}=1, \ldots, 16
$$

Azokban az esetekben, amikor az adott modellben a Durbin-Watson-mutató értéke 1,8 alatti lett volna (pozitív autokorreláció), még egy évvel korábbi adatot is figyelembe vettünk, és ezt addig ismételtük, ameddig a Durbin-Watson-mutató értéke már 2-höz közelített. Ily módon az adott évi teljesítményre nem csak az adott évi, hanem az előző évi (vagy még az azt megelőző évre, évekre jellemző) intézkedéseket és sajátosságokat is figyelembe vettük, így teret adva a függő változóra gyakorolt hatásuk érvényesülésének. Ezért a regressziós becslőfüggvényeink bizonyos esetekben így módosultak:

$$
\begin{array}{lrr}
y_{i t}=\alpha+\beta^{\prime} X_{i t}+\beta^{\prime} X_{i(t-1)}+\beta y_{i(t-1)}+u_{i}+\varepsilon_{i t} & \mathrm{i}=1, \ldots, 28 & \mathrm{t}=1, \ldots, 16 ; \\
y_{i t}=\alpha+\beta^{\prime} X_{i t}+\beta^{\prime} X_{i(t-1)}+\beta^{\prime} X_{i(t-2)}+\beta y_{i(t-1)}+\beta y_{i(t-2)}+u_{i}+\varepsilon_{i t} & \mathrm{i}=1, \ldots, 28 & \mathrm{t}=1, \ldots, 16 ; \\
y_{i t}=\alpha+\beta^{\prime} X_{i t}+\beta^{\prime} X_{i(t-1)}+\beta^{\prime} X_{i(t-2)}+\beta^{\prime} X_{i(t-3)}+\beta y_{i(t-1)}+\beta y_{i(t-2)}+\beta y_{i(t-3)}+u_{i}+\varepsilon_{i t} & \\
& \mathrm{i}=1, \ldots, 28 & \mathrm{t}=1, \ldots, 16 .
\end{array}
$$

A vizsgált 8 éves időszakokban is előfordultak ilyen esetek, természetesen ezekben is ugyanígy jártunk el. Összesen 3-szor 10 regressziós vizsgálatot futtattunk le (három időszak és tíz függő változó). A továbbiakban ismertetjük e vizsgálatok eredményeit.

\subsection{A VIZSGÁLAT EREDMÉNYEI}

A vizsgálatok eredményeit a 6.2., 6.3. és 6.4. táblázatok szemléltetik. A teljes 16 éves időszakban mutatkozó összefüggéseket a 6.2. táblázat foglalja össze. Ebböl látható, hogy a

\footnotetext{
${ }^{67}$ http://gretl.sourceforge.net/
} 
legtöbb kiválasztott magyarázó változóval érzékeny a függő változók kapcsolata. Mindamellett számos változó hatása ciklikus, azaz egyik évben pozitív, a következő évben negatív hatással bír. Ennek az egyik oka lehet, hogy a vizsgált függő változók (vagyis a munkapiaci kimenetek) alakulását más (a modellen kívüli) tényezők is befolyásolják. Az általunk vizsgált 16 éves időszakra megállapítható, hogy a fiatalok foglalkoztatottságát növeli, vagy a munkanélküliségüket csökkenti a részmunkaidősök összes foglalkoztatotton belüli arányának növekedése, a határozott idejü munkaszerződéssel dolgozók összes alkalmazotton belüli arányának növekedése, a munkavállalók védelmével kapcsolatos szabályok szigorítása, az aktív munkaeröpiaci politikai kiadások GDP-n belüli arányának növekedése, a GDP növekedése, valamint a fogyasztóiár-index növekedése. A fiatalok foglalkoztatását csökkentő (és munkanélküliségét növelö) tényező a szakszervezeti szervezettség szintjének növekedése és a nem önkéntesen részmunkaidőben dolgozók arányának növekedése, valamint a passzív munkaerőpiaci politikai kiadások GDP-n belüli arányának növekedése.

A teljes munkaerő munkapiaci helyzetére kedvező hatással bír a határozott idejü munkaszerződéssel dolgozók összes alkalmazotton belüli arányának növekedése, a munkavállalók védelmével kapcsolatos szabályok szigorodása, az aktív munkaerőpiaci politikai kiadások GDP-n belüli arányának növekedése, valamint a GDP-növekedés. A teljes foglalkoztatást csökkenti, vagy a munkanélküliséget növeli a részmunkaidősök növekvő aránya, a nem önkéntesen részmunkaidőben dolgozók arányának növekedése, az átlagos heti munkaórák számának emelkedése, a passzív munkaerőpiaci politikai kiadások GDP-n belüli arányának növekedése, valamint az egy före jutó GDP és a fogyasztóiár-index növekedése. A 25-54 éves korosztályra hasonló eredmények adódtak, kivéve, hogy az átlagos heti munkaórák számának emelkedése itt csökkentőleg hatott a munkanélküliségre, valamint, hogy esetükben a minimálbér átlagkeresethez viszonyított arányának növekedése és a szakszervezeti szervezettség növelte a foglalkoztatást.

Az idősebb korosztály foglalkoztatottságát növeli, vagy a munkanélküliségüket csökkenti a minimálbér átlagkeresethez viszonyított arányának növekedése, a szakszervezeti szervezettség, a részmunkaidősök arányának növekedése, a munkavállalók védelmével kapcsolatos szabályok szigorodása, valamint az aktív munkaerőpiaci politikai kiadások GDP-n belüli arányának növekedése. Az idősebb korosztály munkapiaci helyzetére kedvezőtlen hatása van az adóék növekedésének, a nem önkéntesen részmunkaidőben dolgozók aránya növekedésének, a növekvő heti munkaóráknak, a GDP-arányos passzív munkaerőpiaci politikai kiadások növekedésének, valamint az egy före jutó GDP növekedésének. 
6.2. táblázat A teljes vizsgált időszakra (2000-2015) kapott eredmények összefoglalása

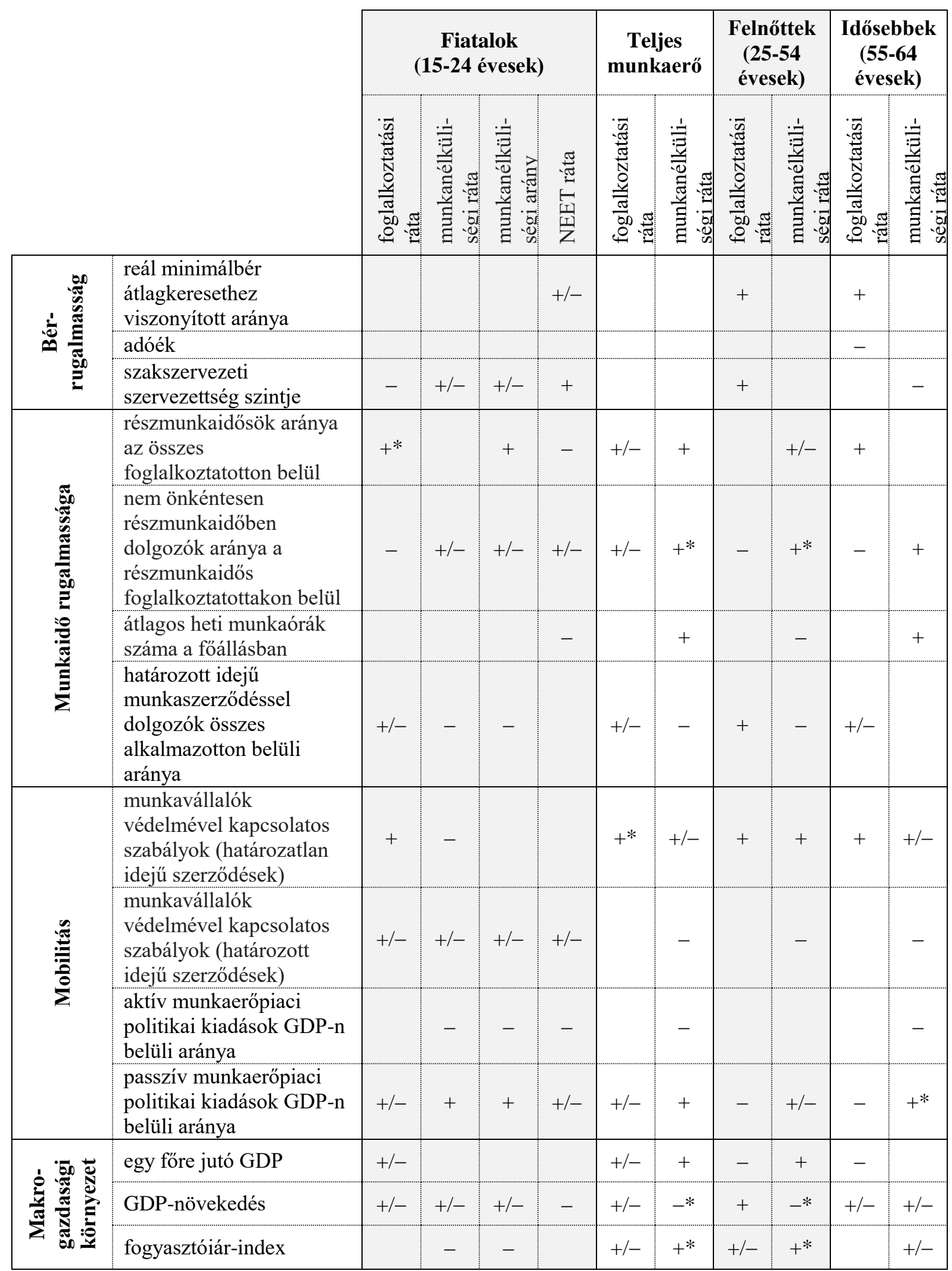

Megjegyzés: a „,+” jel azt jelenti, hogy a magyarázó változó változása azonos irányban változtatja a függő változó értékét; a ,-" jel azt, hogy ellentétes irányban; a „,/-” jel pedig azt, hogy több évre visszatekintve egy évben azonos, más évben ellentétes hatással bír a magyarázó változó változása. A „*” azt jelöli, hogy több évre visszatekintve két évben a táblázatban megadott irányba hatott a magyarázó változó változása, és egy évben ellentétes irányba.

Forrás: saját szerkesztés. 
A jelentősebb eltérések a korcsoportok között a bérrugalmasság dimenziójában azt mutatják, hogy a bérrugalmasság növekedése hozzájárul a fiatalok foglalkoztatottságának javulásához, míg a felnőtt és idősebb korosztályokban inkább ennek ellenkezője figyelhető meg (kivéve az adóék növekedésének idősebbek foglalkoztatására gyakorolt negatív hatását). A munkaidő rugalmasságának dimenzióján belül a fóállásban ledolgozott heti munkaórák számának növekedése a fiatalok és a felnőttek körében a munkanélküliségi ráták csökkenésével járt, míg az idősebbek körében növelte azt. A mobilitás indikátorait tekintve nem mutatkozott ilyen kiemelendő különbség a korcsoportok munkapiaci kimenetei között.

Tekintettel arra, hogy relatíve sok magyarázó változó bizonyult ciklikus hatásúnak, úgy döntöttünk, hogy a válság előtti és alatti/utáni időszakot érdemes külön-külön is megvizsgálni, a válság torzító hatásainak kiküszöbölése érdekében. A 6.3. táblázat ismerteti a válságot megelőző évekre kapott eredményeket. Jól látható, hogy a sejtésünk beigazolódott, ebben az esetben jóval kevesebb ciklikus hatású változó jelent meg, azaz egyértelmübb egy-egy munkapiaci jellemző hatása a munkaerőpiaci kimenetekre. Így megállapítható, hogy a fiatalok foglalkoztatottságát növelte, vagy a munkanélküliségüket csökkentette a részmunkaidősök arányának növekedése, a határozott idejü munkaszerződéssel dolgozók összes alkalmazotton belüli arányának növekedése, az aktív munkaerőpiaci politikai kiadások GDP-n belüli arányának növekedése, valamint a GDP növekedése. A fiatalok foglalkoztatását csökkentette (és munkanélküliségét növelte) a bérrugalmasság csökkenése (mindhárom indikátor esetében), ${ }^{68}$ a nem önkéntesen részmunkaidőben dolgozók arányának növekedése, a munkaórák számának emelkedése, a munkavállalók védelmével kapcsolatos szabályok szigorodása, a passzív munkaerőpiaci politikai kiadások GDP-n belüli arányának növekedése, valamint az egy före jutó GDP növekedése.

A többi korcsoportra ehhez képest jelentősebb eltérés, hogy

- az adóék változásának hatása a teljes és a felnőtt munkaerő esetében nem bizonyult szignifikánsnak;

- a szakszervezeti szervezettség szintjének növekedése csak a felnőtt munkaerő esetében volt szignifikáns hatású (a teljes és idősebb korosztály esetében nem), viszont a fiatalokkal ellentétben itt növelte a foglalkoztatási rátát;

${ }^{68}$ Ez az eredmény egybevág a 4.4.3. részfejezetben ismertetetett vizsgálatok (Gorry, 2013; NeumarkWascher, 2003; Vamossy, 2014) eredményeivel. 
- a nem önkéntesen részmunkaidősök arányának növekedése a felnőttek esetében csökkentette a munkanélküliséget, a teljes és idősebb korosztály esetében pedig ciklikus hatású változónak bizonyult;

- a munkaórák számának emelkedése csökkentette az idősebbek munkanélküliségi rátáját (a teljes és felnőtt korosztály esetében nem bizonyult szignifikánsnak);

- a munkavállalók védelmével kapcsolatos szabályok szigorodása pozitívan hatott a teljes, a felnőtt és az idősebb korosztály munkapiaci helyzetére is.

Röviden összefoglalva, a válságot megelöző nyolcéves időszakban a bérrugalmasság növekedése hozzájárult mindhárom korcsoport foglalkoztatottságának javulásához, (kivéve a szakszervezeti szervezettség növekedésének a felnőttek foglalkoztatására gyakorolt pozitív hatását). A munkaidő rugalmasságának növekedése javította a foglalkoztatást mindhárom korcsoportban, különösen a részmunkaidősök és a határozott idejü szerződéssel alkalmazottak arányának növekedése. A nem önkéntesen részmunkaidőben dolgozók részmunkaidősökön belüli arányának növekedése a fiatalok körében növelte a munkanélküliségi rátákat, míg a felnőttek esetében csökkentette (a teljes és idősebb munkaerö körében ciklikus hatás jelentkezett). A mobilitás indikátorait tekintve ebben az időszakban sem jelentkezett kiemelendő különbség a korcsoportok munkapiaci kimenetei között. A munkavállalók védelmével kapcsolatos szabályok szigorodása vegyes, az aktív munkaerőpiaci politikákra fordított kiadások GDP-arányos növekedése pedig pozitív hatással bírt. Vagyis a mobilitás dimenzióban inkább a rugalmasság csökkenése eredményezett kedvezőbb munkapiaci kimeneteket (a passzív politikákra fordított kiadások hatásától eltekintve).

A válság alatti és az azt követő évekre végzett regressziós vizsgálat eredményeit a 6.4. táblázat mutatja be. Jól látható, hogy a 16 éves időszakhoz hasonlóan itt is számos ciklikus hatású változó van, ezért kevesebb egyértelmű következtetést lehet levonni. A munkaerőpiaci politikákra fordított közösségi kiadások hatását illetően azonban elmondható, hogy ebben az időszakban az aktív munkaerőpiaci politikai kiadások GDP-n belüli arányának növelése nem járt együtt a munkapiaci kimenetek javulásával (egyedül az idősebb korosztály munkanélküliségi rátájának csökkenéséhez járult hozzá). A passzív munkaerőpiaci politikai kiadások GDP-n belüli arányának növekedése pedig kifejezetten a foglalkoztatási ráták csökkenését és a munkanélküliségi ráták növekedését eredményezte - akárcsak a korábban bemutatott másik két vizsgált időszakban. Ez összhangban áll azzal a szakirodalomban gyakran olvasható nézettel, amely szerint a relatíve nagy összegü munkanélküli segély a munkanélküliség növekedését eredményezheti, vagyis a válság évei alatt erőteljesen érvényesült a helyettesítési hatás. 
6.3. táblázat Az első időszakra (2000-2007) kapott eredmények összefoglalása

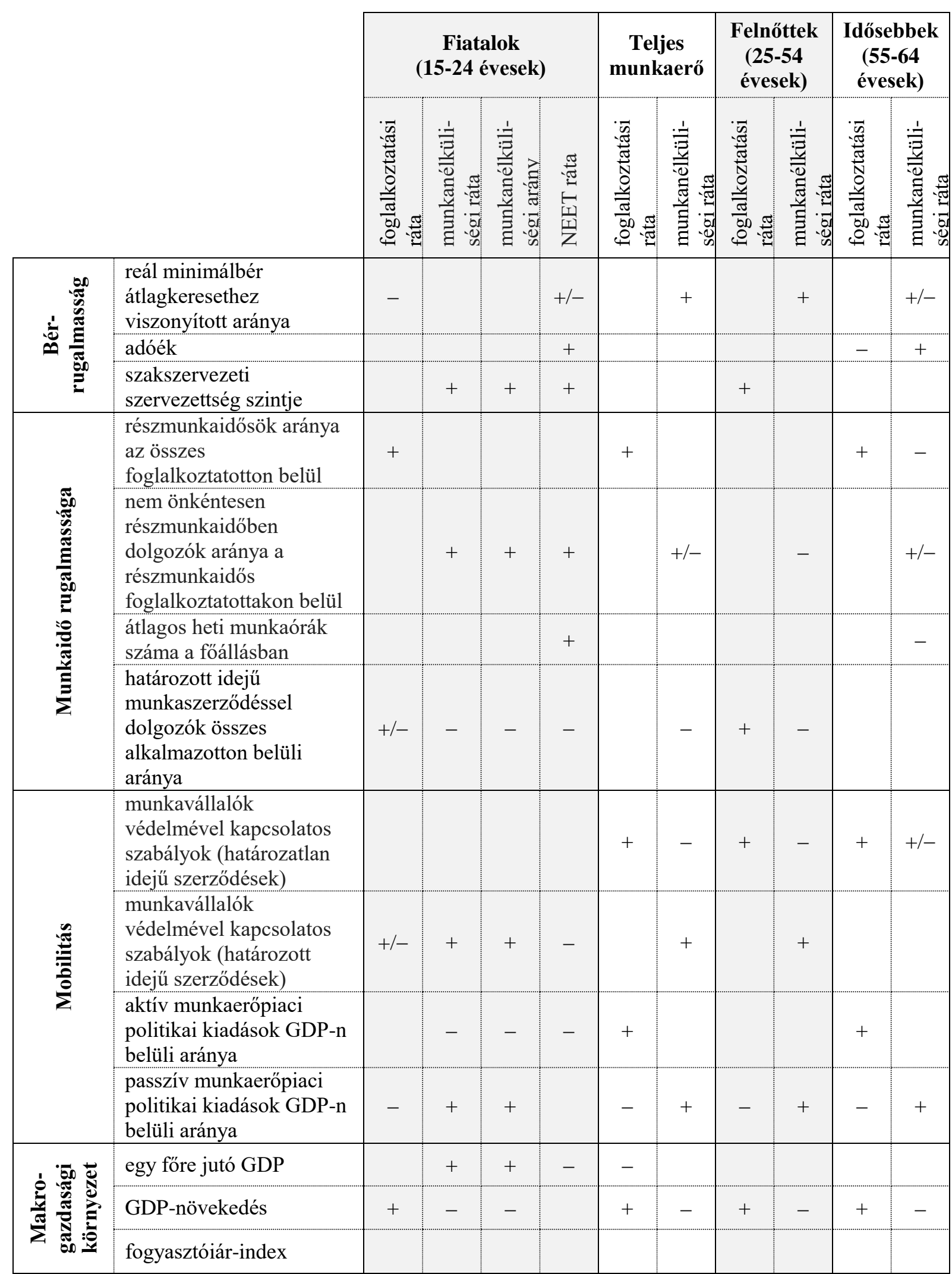

Megjegyzés: a „+" jel azt jelenti, hogy a magyarázó változó változása azonos irányban változtatja a függő változó értékét; a ,-" jel azt, hogy ellentétes irányban; a „+/-" jel pedig azt, hogy több évre visszatekintve egy évben azonos, más évben ellentétes hatással bír a magyarázó változó változása.

Forrás: saját szerkesztés. 
6.4. táblázat A második időszakra (2008-2015) kapott eredmények összefoglalása

\begin{tabular}{|c|c|c|c|c|c|c|c|c|c|c|c|}
\hline & & \multicolumn{4}{|c|}{$\begin{array}{c}\text { Fiatalok } \\
\text { (15-24 évesek) }\end{array}$} & \multicolumn{2}{|c|}{$\begin{array}{c}\text { Teljes } \\
\text { munkaerö }\end{array}$} & \multicolumn{2}{|c|}{$\begin{array}{c}\text { Felnőttek } \\
(25-54 \\
\text { évesek })\end{array}$} & \multicolumn{2}{|c|}{$\begin{array}{c}\text { Idősebbek } \\
\text { (55-64 } \\
\text { évesek) }\end{array}$} \\
\hline & & 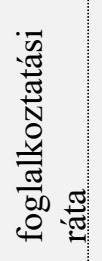 & 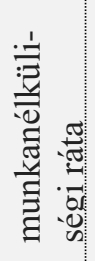 & 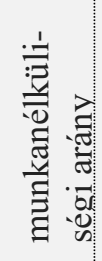 & 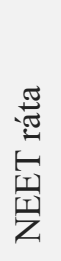 & 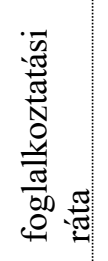 & 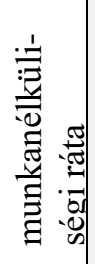 & 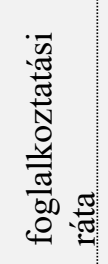 & 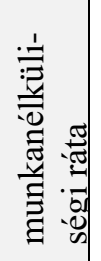 & 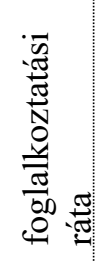 & 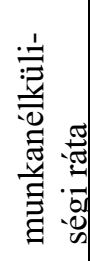 \\
\hline \multirow{3}{*}{ 离 } & $\begin{array}{l}\text { reál minimálbér } \\
\text { átlagkeresethez } \\
\text { viszonyított aránya }\end{array}$ & $+/-$ & + & & + & - & + & + & + & & \\
\hline & adóék & & $+1-$ & + & & + & $+1-$ & + & $+1-$ & & \\
\hline & $\begin{array}{l}\text { szakszervezeti } \\
\text { szervezettség szintje }\end{array}$ & + & & & + & $+1-$ & $+/-$ & -* & $+/-$ & $+/-$ & - \\
\hline \multirow{4}{*}{ 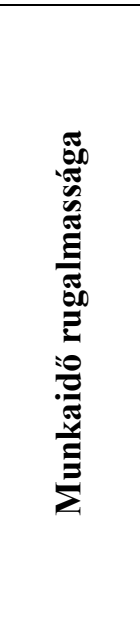 } & $\begin{array}{l}\text { részmunkaidősök aránya } \\
\text { az összes } \\
\text { foglalkoztatotton belül }\end{array}$ & & - & & - & & & + & & & \\
\hline & $\begin{array}{l}\text { nem önkéntesen } \\
\text { részmunkaidőben } \\
\text { dolgozók aránya a } \\
\text { részmunkaidős } \\
\text { foglalkoztatottakon belül }\end{array}$ & & & + & & & - & & & & \\
\hline & $\begin{array}{l}\text { átlagos heti munkaórák } \\
\text { száma a fóállásban }\end{array}$ & & $+/-$ & - & - & - & $+/-$ & $+/-$ & $+1-$ & - & \\
\hline & $\begin{array}{l}\text { határozott idejü } \\
\text { munkaszerződéssel } \\
\text { dolgozók összes } \\
\text { alkalmazotton belüli } \\
\text { aránya }\end{array}$ & $+/-$ & & $+/-$ & & + & - & + & $+/-$ & & \\
\hline \multirow{4}{*}{ 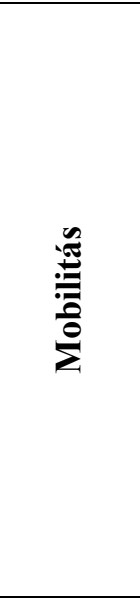 } & $\begin{array}{l}\text { munkavállalók } \\
\text { védelmével kapcsolatos } \\
\text { szabályok (határozatlan } \\
\text { idejü szerződések) }\end{array}$ & $+*$ & - & $+/-$ & & + & $+/-$ & + & $+/-$ & & + \\
\hline & $\begin{array}{l}\text { munkavállalók } \\
\text { védelmével kapcsolatos } \\
\text { szabályok (határozott } \\
\text { idejü szerződések) }\end{array}$ & - & & & & & & & & + & - \\
\hline & $\begin{array}{l}\text { aktív munkaeröpiaci } \\
\text { politikai kiadások GDP-n } \\
\text { belüli aránya }\end{array}$ & - & + & & + & - & & & & & - \\
\hline & $\begin{array}{l}\text { passzív munkaerôpiaci } \\
\text { politikai kiadások GDP-n } \\
\text { belüli aránya }\end{array}$ & - & + & + & + & - & + & - & + & $+/-$ & + \\
\hline \multirow{3}{*}{ 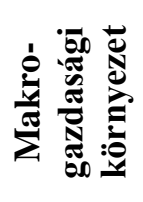 } & egy före jutó GDP & - & + & + & & $+/-$ & + & - & + & & + \\
\hline & GDP-növekedés & - & $+/-$ & - & & + & $+/-$ & + & $+/-$ & + & - \\
\hline & fogyasztóiár-index & & & & - & + & - & $+/-$ & $+/-$ & + & \\
\hline
\end{tabular}

Megjegyzés: a „,+” jel azt jelenti, hogy a magyarázó változó változása azonos irányban változtatja a függő változó értékét; a ,-" jel azt, hogy ellentétes irányban; a „,/-” jel pedig azt, hogy több évre visszatekintve egy évben azonos, más évben ellentétes hatással bír a magyarázó változó változása. A „*” azt jelöli, hogy több évre visszatekintve két évben a táblázatban megadott irányba hatott a magyarázó változó változása, és egy évben ellentétes irányba.

Forrás: saját szerkesztés. 
Minden vizsgálatban jelentős hatással bírt továbbá a vizsgált függő változó előző évi változása is. Mind a foglalkoztatási, mind a munkanélküliségi ráták döntő többségének esetében igaz, hogy az előző évi növekedés a következő évben ceteris paribus szintén növekedést idézett elö.

Összességében az empirikus vizsgálatunk eredményei alapján elmondható, hogy a munkapiaci rugalmasság bérrugalmasság és munkaidő rugalmasság dimenziója alapvetően pozitívan befolyásolja a munkanélküliség alakulását az EU tagországaiban, s eközben nem jelentkezik a rugalmasságnak olyan egyértelmü generációspecifikus hatása, amely egy korosztályt jelentősen kedvezőbben érintene, mint a többit. Így a dolgozat első és második hipotézise igazolásra került. Ezek az eredmények nagyrészt egybevágnak az elméleti fejezetekben leírtakkal, azonban fontos megjegyezni, hogy a vizsgálatunk során csak a foglalkoztatás tényére koncentráltunk, annak minőségére nem. Ez azért fontos, mert - ahogyan a konceptualizálás során is kitértünk rá - a foglalkoztatási ráta növekedése akkor tekinthető igazán kedvező jelenségnek, ha annak hátterében nem a bizonytalan foglalkoztatás terjedése húzódik. A bérrugalmasság, és főként a munkaidő rugalmasság növelésének munkanélküliségcsökkentő hatása valójában azt jelenti, hogy az atipikus foglalkoztatási formák terjedésének köszönhetően növekszik a foglalkoztatás, ami nem csak pozitív hatással bír, hiszen az ilyen jellegü alkalmazásban állók között nem elhanyagolható a sebezhető foglalkoztatottak és a dolgozó szegények aránya. Mindamellett úgy gondoljuk, hogy a foglalkoztatottság növekedése összességében kedvező folyamat.

Másrészt a mobilitás dimenzióját illetően elmondható, hogy a nagyobb mértékű aktív állami beavatkozás segíti a foglalkoztatás javulását (de az EPL, ezen belül a munkavállalók elbocsátás elleni védelmét szolgáló szabályozás jelentősége nem teljesen egyértelmü). Ezt megerősíti az 5.2. alfejezetben bemutatott holland és dán példa is. A passzív juttatások foglalkoztatást csökkentő hatása - a szakirodalmi tapasztalatokkal összhangban - igazolta a helyettesítési hatás létezését. (Meg kell jegyeznünk, hogy a passzív juttatások összege azért is emelkedik, mert növekszik a munkanélküliség, tehát a két tényező kölcsönösen hat egymásra.) A munkaerőpiaci politikai kiadások két típusának egymással ellentétes hatása megnehezíti az a munkaerőpiaci politikákra fordított összes állami költségvetési kiadás hatásának értékelését, ami alátámasztja a dolgozat harmadik hipotézisét. 


\section{7. ÖSSZEFOGLALÁS, KÖVETKEZTETÉSEK}

A dolgozatban az ifjúsági munkanélküliség jelenségével foglalkoztunk, különös hangsúlyt fektetve a munkaerőpiaci rugalmasság különböző dimenzióinak hatásaira. Ennek során elsősorban az Európai Unió térségében jelentkező problémákra fókuszáltunk. Tekintettel a téma aktualitására és összetettségére, nehéz volna néhány mondatban összefoglalni a kutatás eredményeit. Mindenesetre a dolgozatnak vannak érdekes tanulságai.

A szakirodalmi áttekintés alapján az szürhető le, hogy a rugalmatlanság sok esetben korlátozza a munkaerőpiac dinamikáját (azaz a munkaadók és munkavállalók számára kölcsönösen elönyös szerződések megkötését célzó tárgyalásokat), és így alacsonyabb foglalkoztatáshoz vezethet. Ennek az egyik leginkább kitett, veszélyeztetett csoportot jelentik a fiatal pályakezdők. Más szempontból, az olyan, a munkapiacok rugalmatlanságát tükröző feltételek, mint a munkavállalók védelmével kapcsolatos szigorúbb szabályozás, komoly jelentőséggel bírnak a munkapiaci bizonytalanságok csökkentésében és akár a munka termelékenységének növelésében is. Ezáltal a munkapiacok müködésének összetettségét és a rugalmas biztonság rendszereinek sikerességét szem elött tartva azt mondhatjuk, hogy nem létezik a munkapiaci rugalmasságnak (így a bérrugalmasságnak, a munkaidő rugalmasságának és a mobilitásnak) egy olyan ideális szintje, amely minden szempontból kívánatos lenne - tehát egyes, konkrétan meghatározott társadalmi és gazdasági kimenetek elérését egy rugalmasabb, másokét éppen egy erősebben szabályozott munkaerőpiac segítheti. Emellett nagy jelentősége van annak, hogy a munkaerőpiacot társadalmi kontextusban értelmezzük, figyelembe véve az adott országban uralkodó társadalmi normákat, értékeket. Más szóval, mint a közgazdaságtan oly sok más területén, ebben az esetben sem alkalmazható egységes recept a munkaerőpiaci problémák orvoslására.

A témaválasztás egyik kiindulópontja az az elképzelés volt, hogy a munkapiaci flexibilitás jelentőségének pontosabb vizsgálatát segíti, ha azonosítunk egy kisebb csoportot, amelyre vonatkoztatni szeretnénk a különböző rugalmassági dimenziók hatásait. Egyrészt ezért, másrészt az aktuálisan a fiatalok között tapasztalható rendkívüli mértékű munkanélküliség miatt döntöttünk úgy, hogy a dolgozatban a fiatal korosztály helyzetével foglalkozunk. Annak oka pedig, hogy az Európai Unió országai körében vizsgálódtunk, pedig az, hogy Európában az 1970-es évek óta emelkedő munkanélküliség azóta is viszonylag magas maradt, és ennek forrásaként a kutatók az európai munkapiacokra jellemző merevséget szokták megjelölni.

Az ifjúsági munkanélküliség okainak feltárására és összegzésére számos tanulmány készült már. Ezek alapján megállapítható, hogy az okok nagyban megegyeznek az általános 
munkanélküliséghez vezető tényezőkkel (például az alacsony iskolázottság; rossz egészségi állapot; de a bevándorlók vagy elmaradott térségben élő munkavállalók is jellemzően nehezebben találnak állást), ám vannak tipikusan a fiatalokat érintő faktorok is. A szakirodalom ide sorolja az iskolából a munkába való átállás nehézségeivel kapcsolatos strukturális és intézményi tényezőket. Ezek közül az egyik legjelentősebb, hogy a megszerzett végzettség sokszor nem piacképes, vagyis az oktatás/képzés és a munkapiac igényei nem állnak összhangban. Ez azt jelenti, hogy állandó eltérés áll fenn az álláskeresők készségei, képesítése és a munkaerőpiac igényei között: ezt a munkapiaci illeszkedés hibájának nevezzük. Ezen eltérések két nagyobb csoportja a vertikális (készséghiány és készség-kihasználatlanság) és a horizontális (a munkakereslet és munkakínálat minőségbeli eltérései) illeszkedési hiba. A másik nagy strukturális probléma, hogy az elhelyezkedést gyakran nehezíti a szakmai tapasztalat hiánya. Ezen a problémán segíthet a szakmai gyakorlatot is magába építő oktatási és képzési rendszer, föként az alacsonyabb végzettségüek körében. Mindezek mellett empirikus tapasztalatok szerint egyes országokban az üzleti ciklusokra érzékenyebben reagál e korosztály foglalkoztatása, mivel sok fiatal dolgozik az olyan, üzleti ciklusokra érzékeny iparágakban, mint az építőipar, kereskedelem, turizmus, stb., illetve kis- és közepes vállalkozásoknál. Emellett az is jellemző, hogy a fiatalokkal gyakran kötnek hosszabb próbaidejü vagy határozott idejű (sokszor bizonytalan) munkaszerződéseket, amelyeket kedvezőtlen gazdasági körülmények esetén könnyebben, alacsonyabb költségekkel fel tud bontani a munkáltató - bár az ilyen jellegü szerződések segíthetik a munkaerőpiacra való belépést, a tapasztalatszerzést is. A munkapiaci intézmények, mint a munkajogi szabályok, a minimálbér, a kollektív alku és a szakszervezetek szerepe mellett a munkanélküli segélyezés rendszere, a segélyezés időtartama is meghatározó lehet, kiszoríthatja a fiatal munkavállalókat a munkapiacról. Ezek a tényezők mind szorosan kapcsolódnak a munkaerőpiac rugalmassági jellemzőihez.

A fiatal álláskeresők helyzetével azért is érdemes kiemelten foglalkozni, mert a hosszú távon is nagymértékben fennmaradó ifjúsági munkanélküliség súlyos makrogazdasági problémákat és politikai kihívásokat eredményezhet. A hosszú távú ifjúsági munkanélküliség következményei - hasonlóan az általában vett munkanélküliségéhez - sokrétüek lehetnek. A jövedelem-kiesés következtében fellépő anyagi nehézségek, valamint a munka által meghatározott társadalmi státusz és identitás elvesztése következtében megjelenő élettani és pszichológiai sérülések súlyossága gyorsan növekszik a munkanélküliség hosszával párhuzamosan. A fiatalon megtapasztalt munkanélküliség tartós hatással lehet a későbbi termelékenységre és így a foglalkoztatási és kereseti kilátásokra. Hiszen a nagymértékű ifjúsági 
munkanélküliség magában hordozza egy elveszett generáció kialakulásának veszélyét, amelynek tagjai a fiatal kori munkanélküliség következtében fellépő sebhely-hatás miatt későbbi életük során is kedvezőtlen foglalkoztatási kilátásokkal rendelkeznek. Ez a hosszú távú következmény az egyik fő különbség az idősebb és a fiatal korban jelentkező munkanélküliség között.

A szakirodalom alapján az EU munkapiacainak merevségeit, azok hatásait illetően az a következtetés vonható le, hogy az intézmények szerepe jelentős, de nem egyedüli a munkapiaci kimenetek alakulása szempontjából - az aggregált kereslet változása, a makrogazdasági környezet nagyobb hatással bír.

A következökben ismertetjük a korábban megfogalmazott hipotézisek mentén kialakított három tézist. Ezeket a dolgozat empirikus vizsgálatait bemutató fejezete alapján fogalmaztuk meg, az ott kapott eredményeket és az elméleti fejezetekben leírtakat összevetve.

1. tézis: Az ifjúsági munkanélküliség jellemzően az Európai Unió azon országaiban alacsonyabb, ahol nagyobb a bérrugalmasság és munkaidő rugalmasság, vagyis elterjedtebbek az atipikus foglalkoztatási formák.

Vizsgálatunk eredményei egyértelműen alátámasztották, hogy az EU tagállamaiban a munkaerőpiaci rugalmasság bérrugalmasság és munkaidő rugalmasság dimenzióinak növekedése csökkenő ifjúsági munkanélküliséggel párosul, azaz a rugalmasság növelése ezekben az országokban valóban hozzájárul a fiatalok munkapiaci helyzetének javulásához. (A munkapiaci rugalmasság mobilitás dimenziójának ellenben nem ilyen egyértelmű a szerepe.) Más szavakkal, az ifjúsági munkanélküliség jellemzően az Európai Unió azon országaiban alacsonyabb, ahol elterjedtebbek az atipikus foglalkoztatási formák. Ahogyan igaz volt ez a gazdasági válságot megelőző években (2000-2007), úgy a válság alatt és azt követően (20082015 ) is. A vizsgálat korlátja, hogy a foglalkoztatás minőségére vonatkozó megállapítások nem szürhetőek le belőle.

2. tézis: Bár a rugalmas munkaerőpiacok egyes jellemzői eltérően hatnak a fiatalabb és az idősebb korosztály foglalkoztatására, összességében nem mondható el, hogy a nagyobb rugalmasság valamely korosztályt jelentősen kedvezőbb pozícióba hozná a munkaerőpiacon.

Noha az elméleti megközelítés arra enged következtetni, hogy a fiatalok számára előnyösebbek a rugalmas munkapiacok, mint a felnőtt korosztály számára, empirikus vizsgálatunk ezt nem támasztotta alá. Más szóval, általában véve minden vizsgált korcsoportra (15-24, 25-54, 55-64, valamint 15-64 évesek) igaz, hogy a növekvő munkapiaci bérrugalmasság 
és munkaidő rugalmasság többnyire javuló munkapiaci kimeneteket eredményez, a mobilitás indikátorainak hatása pedig vegyesnek mondható. Ebben az esetben is érdemes szem előtt tartani, hogy a vizsgálat során a foglalkoztatás minőségét nem vettük figyelembe - így ebben lehetnek eltérések a korcsoportok között.

3. tézis: Az Európai Unió tagállamaiban az ifjúsági munkanélküliség nagysága és a munkaerōpiaci politikákra fordított állami költségvetési kiadások összege között nincs egyértelmü kapcsolat.

Vizsgálataink eredményei szerint a foglalkoztatási rátákra kedvező hatással vannak a (GDP arányában vett) nagyobb összegü aktív munkaerőpiaci politikai eszközökre fordított kiadások, azonban a passzív eszközökre fordított kiadások növekedése növelte a munkanélküliséget. Ez arra enged következtetni, hogy alapvetően nem a ráfordított összeg nagysága a döntő szempont, hanem az alkalmazott munkapiaci eszközök minősége.

Az Európai Unió már a válságot megelőzően is foglalkozott az ifjúsági munkanélküliség problémájával, leginkább az ezredforduló óta. A fiatalok munkavállalását segítő intézkedések az uniós ifjúságpolitika és foglalkoztatáspolitika keretein belül születnek, valamint kiemelten fontos szerep jut az Európa 2020 stratégiának is. Azonban az ifjúsági munkanélküliség szintje alapvetően a nemzetgazdasági eredményektől és politikáktól függ, a probléma megoldásának kulcsa a tagállamok kezében van. Noha a munkaerőpiaci szabályozás egyre rugalmasabbá válik Európa-szerte, így e tekintetben közelednek egymáshoz az államok, a munkanélkülieket érintő szabályokban továbbra is nagy különbségek vannak az egyes országok között. A dolgozatban áttekintett esetpéldák és az empirikus vizsgálatunk eredménye alapján elmondható, hogy az ifjúsági foglalkoztatottság javításában nagy szerepe van a fiatalokat megcélzó jól megtervezett aktív munkaerőpiaci eszközöknek, valamint az oktatási/képzési rendszer és a munkaerőpiac gyakornoki programokkal történő összekapcsolásának. Ennek érdekében elengedhetetlen a kormányzat és a gazdasági szereplők együttmüködése, illetve még előnyösebb, ha uniós szinten is megvalósul a kooperáció a fiatalok mobilitásának ösztönzésével. Emellett a relatíve rugalmasabb munkaerőpiacokon, ahol a fiataloknak több lehetőségük van részmunkaidős állást vállalni már a tanulmányaik mellett, szintén jobbak az esélyeik.

$\mathrm{Az}$ is látható ezek mellett, hogy az Európai Unióban az ifjúsági munkanélküliség olyan akut probléma, amelynek megoldása érdekében a foglalkoztathatóságot javító strukturális változtatások mellett a NEET fiatalok számára azonnali támogatást is szükséges biztosítani. Ebből a megfontolásból döntött több tagállam is az ifjúsági garanciaprogramok bevezetéséről, 
amelyek nagy előnye, hogy azonnali intézkedéseket követelnek és így elkerülhető a hosszú távú ifjúsági munkanélküliség - és a későbbi kedvezőtlen foglalkoztatási kilátások - kialakulása.

Végül - a dolgozat mottójául választott idézettel kapcsolatban - kiemelendő annak a szerepe, hogy a fiatalok már az iskolaévek alatt tudatosan felkészüljenek a munkaerőpiacra való kilépés buktatóira, ismerjék meg a lehetőségeiket. Ezt is segítheti az oktatási rendszerbe beépített gyakorlati képzés, a tanulás melletti (részmunkaidős) munkavégzés, és a karriertanácsadás.

A kutatás nem tekinthető lezártnak, hiszen újabb kérdések is felmerültek, amelyeket e dolgozat keretében már nem volt módunk vizsgálni. Egyrészt érdemes lenne a foglalkoztatás minőségét jellemző mutatók alakulását is vizsgálni, ezek kapcsolatát a munkapiaci rugalmasság dimenzióival a különböző korcsoportokban. Így meglehet, hogy a munkaerőpiaci rugalmasság generációspecifikus hatásaival kapcsolatban árnyaltabb eredményeket kapnánk. Másrészt beszédes lehet, ha a munkaerőpiaci politikákra fordított kiadások egyes kategóriáinak hatásait nem összességében, hanem elkülönítve vizsgáljuk, így meghatározhatóvá válik, hogy az egyes országokban mely intézkedések tekinthetők a legeredményesebbnek. Ezeken kívül további, rendkívül érdekes kérdések merültek fel az oktatás hatékonyságával, az oktatás és a munkaerőpiaci kimenetek közötti összefüggésekkel kapcsolatban is, amelyekre a dolgozatban nem volt módunk kitérni, de amelyeket érdemes lenne az oktatásgazdaságtan keretei között tovább vizsgálni. 


\section{FELHASZNÁLT IRODALOM}

Agnello, L. - Castro, V. - Jalles, J. T. - Sousa, R. M. (2014): Fiscal adjustments, labour market flexibility and unemployment. Economics Letters, 124, 231-235. o.

Aleksynska, M. - Cazes, S. (2014): Comparing indicators of labour market regulations across databases: A post scriptum to the employing workers debate. Conditions of Work and Employment Series No. 50, International Labour Office, Geneva.

Allan, A. - Daniels, L. (1999): Part-Time Workers. CIPD, London.

Almeida, R. K. - Aterido, R. (2008): The incentives to invest in job training: Do strict labor codes influence this decision? Social Protection and Labor Policy and Technical Notes 46189, The World Bank.

Álvarez, I. C. - Barbero, J. - Zofío, J. L. (2017): A Panel Data Toolbox for MATLAB. Journal of Statistical Software, 76, 6, 1-27. o.

Andorka Rudolf (2006): Bevezetés a szociológiába. Osiris Kiadó, Budapest.

Anyanwu, J. C. (2014): Does Intra-African Trade Reduce Youth Unemployment in Africa? Working Paper Series $\mathrm{N}^{\circ}$ 201, African Development Bank, Tunis.

Arpaia, A. - Curci, N. (2010): EU labour market behaviour during the great recession. European Economy, Economic Papers, 405. (Letöltve: 2015.01.28. http://ec.europa.eu/economy_finance/publications/economic_paper/2010/pdf/ecp405_en .pdf)

Artner Annamária (2009): Válság és foglalkoztatás. Eszmélet, 84. sz. 2009. tél, 30-49. o.

Artner Annamária (2013): A fiatalok munkanélküliségének kérdéséhez Európa példáján keresztül. Közgazdasági Szemle, 12, 1370-1392. o.

Auer, P. (2007): Security in labour markets: Combining flexibility with security for decent work. Economic and Labour Market Papers 2007/12, International Labour Office, Geneva.

Azeng, T. F. - Yogo, T. U. (2013): Youth Unemployment and Political Instability in Selected Developing Countries. Working Paper Series $\mathrm{N}^{\circ} 171$, African Development Bank, Tunis.

Bălan, M. - Bălan, G.-S. (2012): Young Labor Market in the Global Crisis. Hyperion International Journal of Econophysics \& New Economy, 2, 323-332. o.

Balcsók István (2005): A munkanélküliség területi egyenlőtlenségei és legjellemzőbb folyamatainak alakulása az 1992-2002 közötti időszakban. Doktori (PhD) értekezés, Debreceni Egyetem, Természettudományi Kar, Debrecen.

Banerji, A. - Saksonovs, S. - Lin, H. - Blavy, R. (2014): Youth Unemployment in Advanced Economies in Europe: Searching for Solutions. IMF Staff Discussion Note, Vol. 14., No. 11., http://dx.doi.org/10.5089/9781498337113.006

Beissinger, T. - Moeller, J. (2000): Unemployment: Theoretical Explanation. In Wagner, H. (szerk.): Globalization and Unemployment. Springer, Berlin, 89-133. o.

Bell, D. N. F. - Blanchflower, D. G. (2010): Youth Unemployment: Déjà Vu? IZA Discussion Paper No. 4705, January 2010. http://ftp.iza.org/dp4705.pdf

Bernal-Verdugo, L. E. - Furceri, D. - Guillaume, D. M. (2012): Labor Market Flexibility and Unemployment: New Empirical Evidence of Static and Dynamic Effects. Comparative Economic Studies, Palgrave Macmillan;Association for Comparative Economic Studies, 54, 2, 251-273. o. DOI: 10.1057/ces.2012.3

Biggins, C. (2012): A demanding job: finding sustainable employment for Britain's youth. CentreForum, London.

Blanchard, O. (2006): European unemployment: the evolution of facts and ideas. Economic Policy, 21, 45, 5-59. o. 
Boeri, T. - Conde-Ruiz, J. I. - Galasso, V. (2012): The Political Economy Of Flexicurity. Journal of the European Economic Association, 10, 4, 684-715. o. DOI: 10.1111/j.15424774.2012.01065.x

Borbély-Pecze, T. B. - Hutchinson, J. (2013): The Youth Guarantee and Lifelong Guidance. European Lifelong Guidance Policy Network Concept Note No. 4.

Breen, P. J. - Shiønnemann, M-E. - Nurse, L. A. - Azzopardi, A. - Lagree, J-C. - Lauritzen, P. (2003): Youth policy in Lithuania. Council of Europe Publishing, Strasbourg.

Breen, R. (2005): Explaining Cross-national Variation in Youth Unemployment: Market and Institutional Factors. European Sociological Review, 21, 2, 125-134. o.

BusinessEurope (2015): Labour markets reforms and implementation of country specific recommendations in 2014. April 2015. https://www.businesseurope.eu/sites/buseur/files/media/imported/2015-00313-E.pdf

BusinessEurope - CEEP - UEAPME - ETUC (2015): The 2015-2017 work programme of the European social partners: partnership for inclusive growth and employment. http://resourcecentre.etuc.org/spaw_uploads/files/FINAL_Joint_Social_Dialogue_Work _Programme_2015_2017.pdf

Buzás Norbert - Lukovics Miklós (2015): A felelősségteljes innovációról. Közgazdasági Szemle, 62, 4, 438-456. o.

Byrne, D. - Strobl, E. (2004): Defining unemployment in developing countries: evidence from Trinidad and Tobago. Journal of Development Economics, 73, 1, 465-476. o.

Cahuc, P. - Carcillo, S. - Rinne, U. - Zimmermann, K. F. (2013): Youth Unemployment in Old Europe: The Polar Cases of France and Germany. IZA Journal of European Labor Studies, 2, 18, 1-23. o., https://link.springer.com/article/10.1186/2193-9012-2-18

Caporale, G. M. - Gil-Alana, L. A. (2014): Youth Unemployment in Europe: Persistence and Macroeconomic Determinants. Comparative Economic Studies, 56, 4, 581-591. o., http://dx.doi.org/10.1057/ces.2014.29

Card, (D. 2011): Origins of the Unemployment Rate: The Lasting Legacy of Measurement without Theory. American Economic Review, 101, 3, 552-557. o.

Casaux, S. - Turrini, A. (2011): Post-crisis unemployment developments: US and EU approaching? ECFIN Economic Briefs, 13, 1-7. o.

CDPS (2001): The social and family consequences and costs of the unemployment of young people. Steering Committee on Social Policy, Strasbourg, 97, 9, 107 o.

Chabanet, D. (2014): Between Youth Policy and Employment Policy: The Rise, Limits and Ambiguities of a Corporatist System of Youth Representation within the EU. Journal of Common Market Studies, 3, 479-494. o.

Choudhry, M. T. - Marelli, E. - Signorelli, M. (2012): Youth unemployment rate and impact of financial crises. International Journal of Manpower, 1, 76-95. o.

Cinalli, M. - Giugni, M. (2013): New challenges for the welfare state: The emergence of youth unemployment regimes in Europe? International Journal of Social Welfare, 3, 290-299. o.

Coles, B. - Godfrey, C. - Keung, A. - Parrot, S. - Bradshaw, J. (2010): Estimating the life-time cost of NEET: 16-18 year olds not in Education, Employment or Training. Research conducted for the Audit Commission by University of York, York. https://www.york.ac.uk/inst/spru/research/pdf/NEET.pdf

Crowley, L. - Jones, K. - Cominetti, N. - Gulliford, J. (2013): International Lessons: Youth unemployment in the global context. Report from The Missing Million Programme, The Work Foundation, Lancaster University.

Daniels, A. K. (1987): Invisible Work. Social Problems, 34, 5, 403-415. o.

Demidova, O. - Signorelli, M. (2012): Determinants of youth unemployment in Russian regions. Post-Communist Economies, 24, 2, 191-217. o. 
Desjardins, R. - Rubenson, K. (2011): An Analysis of Skill Mismatch Using Direct Measures of Skills. OECD Education Working Papers, No. 63, OECD Publishing, Paris. http://dx.doi.org/10.1787/5kg3nh9h52g5-en

Dietrich, H. (2012): Youth Unemployment in Europe. Theoretical Considerations and Empirical Findings. Friedrich Ebert Stiftung, Berlin.

Duell, N. (2012): Can active labour market programmes reduce long-term unemployment? Thematic Review Seminar on "Tackling Long-Term unemployment - effective strategies and tools to address long-term unemployment”, Brussels, 8 November 2012, Mutual Learning Programme, Autumn Seminar 2012. (Letöltve: 2015.03.18. http://ec.europa.eu/social/BlobServlet?docId=10926\&langId=en)

Dutt, P. - Mitra, D. - Ranjan, P. (2009): International Trade and Unemployment: Theory and Cross-National Evidence. Journal of International Economics, 78, 1, 32-44. o.

Eckel, C. (2003): Labor market adjustments to globalization: unemployment versus relative wages. North American Journal of Economics and Finance, 14, 173-188. o.

Eggert, W. - Krieger, T. - Meier, V. (2010): Education, unemployment and migration. Journal of Public Economics, 94, 5-6, 354-362. o.

Eichhorst, W. (2013): The European Labour Market. Success through Flexibility and Mobility. Konrad Adenauer Stiftung, Berlin.

Elgrably-Lévy, N. (2006): The minimum wage and labour market flexibility. Economic Note, Labour Law Series, Montreal Economic Institute, December 2006.

ETUC (2014): Annual Growth Survey 2015: Europe must have a new start. European Trade Union Confederation, Brussels.

Eurofound (2012a): NEETs - Young people not in employment, education or training: Characteristics, costs and policy responses in Europe. Publications Office of the European Union, Luxembourg.

Eurofound (2012b): Youth Guarantee: Experiences from Finland and Sweden. Publications Office of the European Union, Luxembourg.

Európai Bizottság (2007): A rugalmas biztonság közös elveinek kidolgozása felé: több és jobb munkahely a rugalmasságon és biztonságon keresztül. COM(2007) 359 végleges, Brüsszel, 2007. 06. 27.

Európai Bizottság (2010): EURÓPA 2020 - Az intelligens, fenntartható és inkluzív növekedés stratégiája. A Bizottság közleménye, Brüsszel, 2010. 03. 03. (Letöltve: 2015. 01. 09. http://eur-

lex.europa.eu/LexUriServ/LexUriServ.do?uri=COM:2010:2020:FIN:HU:PDF)

Európai Bizottság (2013): Uniós intézkedések az ifjúsági munkanélküliség leküzdésére. Feljegyzés. Brüsszel, 2013. május 28. (Letöltve: 2014.11.01. http://europa.eu/rapid/press-release_MEMO-13-464_hu.htm)

Európai Bizottság (2016): 2016. évi országjelentés - Magyarország. Bizottsági Szolgálati Munkadokumentum. Brüsszel, 2016. február 26. (Letöltve: 2016.07.10. http://ec.europa.eu/europe2020/pdf/csr2016/cr2016_hungary_hu.pdf)

European Commission (2013): Report on youth employment action teams: update for the spring European Council. European Commission, 2013.03.12. (Letöltve: 2015.03.26. http://ec.europa.eu/europe2020/pdf/barroso/report_en.pdf)

European Commission (2014): Annual Report on European SMEs 2013/2014 - A Partial and Fragile Recovery. European Commission, Brussels. (Letöltve: 2014.10.30. http://www.eubusiness.com/topics/sme/report-2014)

Eurostat (2014): Statistics Explained: Labour market glossary. (Letöltve 2014.10.21. http://epp.eurostat.ec.europa.eu/statistics_explained/index.php/EU_labour_force_survey -_methodology)

Eurostat (2016): Statistics. http://ec.europa.eu/eurostat/data/database

Eurostat (2017): Statistics. http://ec.europa.eu/eurostat/data/database 
Falusné Szikra Katalin (1999): Globalizáció és munkapiac, különös tekintettel a magasan fejlett országokra. Közgazdasági Szemle, 46, 1, 20-34. o.

Fan, C. S. - Stark, O. (2007): International migration and "educated unemployment". Journal of Development Economics, 83, 1, 76-87. o.

Farkas Beáta (2011a): A piacgazdaság intézményrendszere az Európai Unió új tagállamaiban. Statisztikai Szemle, 89, 1, 50-76. o.

Farkas Beáta (2011b): The Central and Eastern European model of capitalism. Post-Communist Economies, 23, 1, 15-34. o.

Farkas Péter (2007): A közgazdasági elméleti iskolák a foglalkoztatásról, különös tekintettel a globalizáció hatásaira. I rész. Munkaügyi Szemle, 9, 27-31. o.

Felbermayr, G. - Prat, J. - Schmerer, H.-J. (2011): Trade and unemployment: What do the data say? European Economic Review, 55, 6, 741-758. o.

Fenwick, C. - Howe, J. - Marshall, S. - Landau, I. (2007): Labour and labour-related laws in micro and small enterprises: Innovative regulatory approaches. SEED Working Paper 81, Small enterprise programme, ILO, Geneva.

Finna Henrietta (2008): A munkaerőpiaci rugalmasságot elősegítő atipikus foglalkoztatási formák a hazai kis- és középvállalkozásoknál. Ph.D. értekezés, Budapesti Müszaki és Gazdaságtudományi Egyetem Gazdaság- és Társadalomtudományi Kar, Budapest.

Ghai, D. (2003): Decent work: Concept and indicators. International Labour Review, 142, 2 , 113-145. o.

Giguère, S. - Froy, F. (2009a) (ed.): Flexible Policy for More and Better Jobs. Local Economic and Employment Development, OECD, Paris.

Giguère, S. - Froy, F. (2009b): A New Framework for Labour Market Policy in a Global Economy. In Giguère, S. - Froy, F. (ed.): Flexible Policy for More and Better Jobs. Local Economic and Employment Development, OECD, Paris, 17-34. o.

Giugni, M. - Lorenzini, J. (2012): Employment Status and Political Participation: Does Exclusion Influence the Protest Behavior of the Young Unemployed? In AndreossoO'Callaghan, B. - Royall, F. (szerk.): Economic and Political Change in Asia and Europe. Springer, Berlin, 179-195. o.

Gorry, A. (2013): Minimum wages and youth unemployment. European Economic Review, 64, C, 57-75. o.

Gregg, P. (2001): The Impact of Youth Unemployment on Adult Unemployment in the NCDS. The Economic Journal, 111, 475, 626-653. o.

Guerazzi, M. - Meccheri, N. (2012): From wage rigidity to labour market institution rigidity: A turning-point in explaining unemployment? The Journal of Socio-Economics, 41 189197. o.

Harms, P. - Hefeker, C. (2003): Globalization and unemployment: the role of international diversification. Economics Letters, 78, 281-286. o.

Hárs Ágnes (2013): Atipikus foglalkoztatási formák Magyarországon a kilencvenes és a kétezres években. Közgazdasági Szemle, 60, 2, 224-250. o.

Hellier, J. - Chusseau, N. (2010): Globalization and the Inequality - Unemployment Tradeoff. Review of International Economics, 18, 5, 1028-1043. o. DOI:10.1111/j.14679396.2010.00924.x

Heyne, P. - Boettke, P. J. - Prychitko, D. L. (2004): A közgazdasági gondolkodás alapjai. Nemzeti Tankönyvkiadó, Budapest, 520 o.

Hilson, G. - Osei, L. (2014): Tackling youth unemployment in sub-Saharan Africa: Is there a role for artisanal and small-scale mining? Futures, 62, Part A, 83-94. o.

HM Treasury (2003): EMU and Labour Market Flexibility. HMSO, London.

Hori, K. (2008): Economic Growth, Unemployment, and Business Cycles. Keio/Kyoto Joint Global COE Discussion Paper Series 2008-039, Keio/Kyoto Joint Global COE Program. 
Horváth Gergely (2006): A munkapiaci intézmények hatása a munkanélküliségi rátára. Közgazdasági Szemle, 9, 744-768. o.

Horváth Hedvig - Hudomiet Péter (2005): Munkapiaci trendek Magyarországon, 2004. In Fazekas K. - Koltay J. (szerk.): Munkaeröpiaci Tükör 2005. MTA Közgazdaságtudományi Intézet, Budapest, 15-33. o.

House of Lords (2014): Youth unemployment in the EU: a scarred generation? House of Lords Paper 164, 2013-14. Stationery Office, London.

Hughes, D. - Borbély-Pecze, T. B. (2013): Youth Unemployment: A Crisis in Our Midst - The role of lifelong guidance policies in addressing labour supply and demand. European Lifelong Guidance Policy Network Concept Note No. 2.

ILO (1999): Report of the Director-General: Decent Work. International Labour Conference, $87^{\text {th }}$ Session, International Labour Office, Geneva.

ILO (2014): Skills mismatch in Europe. Statistics Brief, September 2014. International Labour Office, Geneva.

ILO (2015a): Global employment trends for youth 2015: Scaling up investments in decent jobs for youth. International Labour Office, Geneva.

ILO (2015b): Non-standard forms of employment. Report for discussion at the Meeting of Experts on Non-Standard Forms of Employment (Geneva, 16-19 February 2015). International Labour Office, Conditions of Work and Equality Department, Geneva.

ILO (2016a): World Employment and Social Outlook 2016: Trends for Youth. International Labour Office, Geneva.

ILO (2016b): Key Indicators of the Labour Market, Ninth edition. International Labour Office, Geneva.

IMF (2014): Euro Area Policies: Selected Issues, July 2014. International Monetary Fund, Washington, D.C.

Jensen, P. - Rosholm, M. - Svarer, M. (2003): The response of youth unemployment to benefits, incentives, and sanctions. European Journal of Political Economy, 2, 301-316. o.

Jimeno, J. F. - Rodríguez-Palenzuela, D. (2002): Youth Unemployment in the OECD: Demographic Shifts, Labour Market Institutions and Macroeconomic Shocks. European Central Bank Working Paper Series, No. 155. http://www.central.banktunnel.eu/pub/pdf/scpwps/ecbwp155.pdf

Kahn, L. M. (2011): Labor Market Policy: A Comparative View on the Costs and Benefits of Labor Market Flexibility. Journal of Policy Analysis and Management, Vol. 31., No. 1., 94-110. o., http://dx.doi.org/10.1002/pam.20602

Katz, L. F. (1986): Efficiency Wage Theories: A Partial Evaluation. NBER Macroeconomics Annual 1986, 1, 235-290. o. http://www.nber.org/chapters/c4248

Kawaguchi, D. - Murao, T. (2012): Who bears the cost of the business cycle? Labor-market institutions and volatility of the youth unemployment rate. IZA Journal of Labor Policy, 10, 1-22. 0 .

Kawaguchi, D. - Murao, T. (2014): Labor Market Institutions and Long-Term Effects of Youth Unemployment. Journal of Money, Credit and Banking, 46, S2, 95-116. o.

Keller, B. - Seifert, H. (2005): Atypical Employment and Flexicurity. Management Revue, The International Review of Management Studies, 16, 3, 304-323. o.

Khemraj, T. - Madrick, J. - Semmler, W. (2006): Okun's Law and Jobless Growth. SCEPA policy note series No. 3. Schwartz Center for Economic Policy Analysis (SCEPA), The New School.

http://www.economicpolicyresearch.org/images/docs/research/employment/0603_PN_ Okun's_Law.pdf 
Kim, H. (2009): Economic Performance in Three Labor Market Models: Flexibility, Rigidity, and Flexicurity. Paper presented at 15th IIRA World Congress, Sydney, Australia, 2428 August 2009.

Kiss Gábor Dávid (2017): Volatilitás, extrém elmozdulások és tökepiaci fertözések. JATEPress Kiadó, Szeged. 113 o.

Klau, F. - Mittelstadt, A. (1986): Labour market flexibility. OECD Economic Studies, 6, 8-45. o.

Knotek, E. S. (2007): How Useful is Okun's Law? Economic Review, Q IV., 73-103. o.

Koncz Katalin (2006): A felzárkózás elmaradása: a magyar nők munkaerő-piaci helyzete. Statisztikai Szemle, 84, 7, 651-674. o.

Korenman, S. - Neumark, D. (2000): Cohort Crowding and Youth Labor Markets (A CrossNational Analysis). In Blanchflower, D. G. - Freeman, R. B. (szerk.): Youth Employment and Joblessness in Advanced Countries. University of Chicago Press, Chicago, 57-106. o.

Köllő János (szerk.) (2013): Foglalkoztatási csodák Európában - Tanulságok a munkaeröpiaci elörejelzés számára. MTA Közgazdaság- és Regionális Tudományi Kutatóközpont, Budapest.

Körösi István (2012): Az Európa 2020 Stratégia, az EUREKA szerepe és kilátásai. Kihívások, 205. sz.

Kreivys, D. 2010: Post-crisis Lithuania - lessons and recovery. Baltic rim Economies, 7, 6, 23. 0 .

Kroft, K. - Lange, F. - Notowidigdo, M.J. - Katz, L.F. (2016): Long-Term Unemployment and the Great Recession: The Role of Composition, Duration Dependence, and NonParticipation. Journal of Labor Economics, 34 S1, Part 2, S7-S54. o.

KSH (2015): Munkaerő-piaci helyzetkép, 2014. Statisztikai Tükör, 45, 1-8. o.

Kun András István (2013): Oktatási jelzés és szürés a munkaeröpiacon - az empirikus vizsgálatok tanulságai. Competitio, 12, 2, 5-26. o.

Laczi Renáta - London András - Pelle Anita - Végh Marcell Zoltán (2016): Várakozások és innováció az Európai Unióban: összefüggések, folyamatok, hatások. In Lengyel Imre Nagy Benedek (szerk.): Térségek versenyképessége, intelligens szakosodása és újraiparosodása, JATEPress, Szeged, 79-102. o.

Lahusen, C. - Schulz, N. - Graziano, P. R. (2013): Promoting social Europe? The development of European youth unemployment policies. International Journal of Social Welfare, 22, 300-309. o.

Lakatos Judit (2012): Új uniós mutatók a munkanélküliségi ráta információtartalmának kiegészítésére. Statisztikai Szemle, 2-3, 206-214. o.

Lam, D. (2014): Youth bulges and youth unemployment. IZA World of Labor, May, 1-10. o.

Lavery, S. (2014): The politics of precarious employment in Europe: 'Zero Hour' contracts and the commodification of work. In Cardoso, P. M. - Erdinc, I. - Horemnas, J. - Lavery, S.: Percarious Employment in Europe. FEPS Young Academics Network, Renner Institut, Brussels, 6-16. o.

Lee, S. - Aleksynska, M. - Rani, U. A. - Bonnet, F. - Fenwick, C. - Lansky, M. - Macis, M. - Monti, P. (2014): Labour and social protection institutions: Recent trends and impact on development. World of Work Report, 2014, 1., 85-108. o., doi:10.1002/wow3.48

Lin, M. Y. - Wang, J. S. (2004): Outward Capital Flow and Unemployment. Public Finance, Taiwan, 31-38. o.

Lindahl, L. (2011): Improving the school-to-work transition for vocational students - What can we learn from research? Swedish Institute for Social Research, Stockholm University Working Paper 13/2011.

Lindbeck, A. - Snower, D. J. (2001): Insiders versus Outsiders. Journal of Economic Perspectives, 15, 1, 165-188. o. 
Lipsmeyer, C. S. - Zhu, L. (2011): Immigration, Globalization, and Unemployment Benefits in Developed EU States. American Journal of Political Science, 55, 3, 647-664. o.

Lorenzini, J. - Giugni, M. (2010): Youth Coping with Unemployment: The Role of Social Support. Revue Suisse de Travail Social, 11, 80-99. o.

Lörincz Szabolcs (2000): Reál üzleti ciklusok. Közgazdasági Szemle, 47, 7-8, 509-530. o.

Manca, A. R. - Governatori, M. - Mascherini, M. (2010): Towards a set of Composite Indicators on Flexicurity: a Comprehensive Approach. European Commission, Joint Research Centre, Luxembourg.

Mankiw, N. G. (2011): A közgazdaságtan alapjai. Osiris Kiadó, Budapest, 640. o.

Martus Bettina (2015): Növekedjünk vagy foglalkoztassunk? Az amerikai gazdasági növekedés problémája. Pénzügyi Szemle, 60, 2, 254-274. o.

Martus Bettina - Urbánné Mező Júlia (2016): A munkahelyteremtés nélküli növekedés és az ifjúsági munkanélküliség kapcsolata. Külgazdaság, 60, 5-6, 78-105. o.

Máté Domicián (2010): A kibocsátás és a munkatényező kapcsolata az okuni posztulátum szemszögéböl. Statisztikai Szemle, 10-11, 1106-1122. o.

Matheika Zoltán (2013): Az ifjúsági munkanélküliség magyarországi sajátosságai. FriedrichEbert-Stiftung, Budapest. http://www.fesbp.hu/common/pdf/tanulmany tarki.pdf

Meijers, F. - Te Riele, K. (2004). From Controlling to Constructive: Youth Unemployment Policy in Australia and The Netherlands. Journal of Social Policy, 33, 3-25. o. doi:10.1017/S0047279403007256.

Mező Júlia - Bagi Ágnes (2012): Gyors felzárkózás megszakításokkal - a balti államok válságkezelése. In Farkas Beáta - Voszka Éva - Mező Júlia (szerk.): Válság és válságkezelés az Európai Unió kohéziós országaiban. Szegedi Tudományegyetem Gazdaságtudományi Kar, Szeged, 70-88. o.

Morvay Endre (2012): Munkapiac keresési súrlódásokkal. Közgazdasági Szemle, 59, 2, 139163. 0.

Mploy (2011): Building Flexibility and Accountability Into Local Employment Services: Country Report for Denmark. OECD Local Economic and Employment Development (LEED) Working Papers, 2011/12, OECD Publishing, Paris. DOI: 10.1787/20794797

Mroz, T. A. - Savage, T. H. (2006): The Long-Term Effects of Youth Unemployment. Journal of Human Resources, 2, 259-293. o.

Mouhammed, A. H. (2011): Important Theories of Unemployment and Public Policies. Journal of Applied Business and Economics, 12, 5, 100-110. o.

NFSZ (2014): Tájékoztató az egyes adótörvények és azzal összefüggő egyéb törvények módosításáról szóló 2011. évi CLVI. törvény alapján a Munkahelyvédelmi Akcióterv kedvezményeiről, Budapest, 2014. január. Interneten: http://nfsz.munka.hu/engine.aspx?page=showcontent\&content=ma_tamogatas_mhelyve delmiakcioterv

Nichols, A. - Mitchell, J. - Lindner, S. (2013): Consequences of Long-Term Unemployment. Urban Institute, Washington, D.C. (Letöltve: 2015. 04. 24. http://www.urban.org /uploadedpdf/412887-consequences-oflong-term-unemployment.pdf)

Nickell, S. (1997): Unemployment and Labor Market Rigidities: Europe versus North America. Journal of Economic Perspectives, 3, 11, 55-74. o.

Nickell, S. (1998): Unemployment: Questions and Some Answers. Economic Journal, 108, 802-816. o.

Nickell, S. - Nunziata, L. - Ochel, W. (2005): Unemployment in the OECD since the 1960s. What do we know? The Economic Journal, 115, 500, 1-27. o.

Nunziata, L. (2002): Unemployment, Labour Market Institutions and Shocks. Nuffield College Working Papers in Economics No. 16, Nuffield College, Oxford.

O'Higgins, N. (1997): The challenge of youth unemployment. International Social Security Review, 4, 63-93. o. 
OECD (1983): The Nature of Youth-Adult Unemployment Differentials. In OECD Employment Outlook 1983, OECD Publishing, Paris, 73-80. $о$. http://www.oecd.org/employment/emp/4379563.pdf

OECD (1994): The OECD Jobs Study. OECD Publishing, Paris https://www.oecd.org/els/emp/1941679.pdf

OECD (2010): Off to a Good Start? Jobs for Youth. OECD Publishing. http://www.odx.doi.org/10.1787/9789264096127-en

OECD (2013): Protecting jobs, enhancing flexibility: A new look at employment protection legislation. In OECD Employment Outlook 2013, OECD Publishing, Paris. http://dx.doi.org/10.1787/empl_outlook-2013-6-en

OECD (2015): Activation policies for more inclusive labour markets. In OECD Employment Outlook 2015, OECD Publishing, Paris. http://www.keepeek.com/Digital-AssetManagement/oecd/employment/oecd-employment-outlook-2015/activation-policies-formore-inclusive-labour-markets_empl_outlook-2015-7-en\#.WGug8X252jA\#page1

OECD.Stat (2016): OECD Statistics. http://www.oecd.org/statistics/

OECD.Stat (2017): OECD Statistics. http://www.oecd.org/statistics/

Oravecz Beatrix (2008): Hiányzó adatok és kezelésük a statisztikai elemzésekben. Statisztikai Szemle, 86, 4, 365-384. o.

Owyang, M. T. - Sekhposyan, T. (2012): Okun's Law over the Business Cycle: Was the Great Recession All That Different? Federal Reserve Bank of St. Louis Review, 94, 5, 399-418. o.

Öry Mária (2005): Hátrányos helyzetü csoportok helyzete a munkaeröpiacon. Nemzeti Felnőttképzési Intézet, Budapest.

Park, H. M. (2011): Practical Guides To Panel Data Modeling: A Step-by-step Analysis Using Stata. Tutorial Working Paper. Graduate School of International Relations, International University of Japan.

Pelle Anita (2010): Állami támogatások az Európai Unióban a gazdasági válság idején. Európai Tükör, 15, 9, 32-48.o.

Perugini, C. - Signorelli, M. (2010): Youth labour market performance in European regions. The European Journal of Comparative Economics, 2, 243-278. o.

Pissarides, C. A. (1997): The need for Labour-Market Flexibility in European Economic and Monetary Union, Swedish Economic Policy Review, 4, 2, 513-545. o.

Polónyi István (2002): Az oktatás gazdaságtana. Osiris Kiadó, Budapest.

Potrafke, N. (2013): Globalization and labor market institutions: International empirical evidence. Journal of Comparative Economics, 41, 3, 829-842. o.

Prosser, T. (2015): Dualization or liberalization? Investigating precarious work in eight European countries. Work, Employment \& Society, 30, 6, 1-7. o.

Pula Gábor (2005): Az euro bevezetésével járó strukturális politikai kihívások: munkapiac. MNB-tanulmányok 41, Magyar Nemzeti Bank, Budapest. http://www.mnb.hu/Root/Dokumentumtar/MNB/Kiadvanyok/mnbhu_mnbtanulmanyok /MT 41.pdf

Qayyum, W. (2007): Causes of Youth Unemployment in Pakistan. The Pakistan Development Review, 46, 4, 611-621. o.

Reed, H. (2010): Flexible with the Truth? Exploring the Relationship between Labour Market Flexibility and Labour Market Performance. A Report for the TUC, Landman Economics, London.

Reinders, H. (2012): Migrant Youth in Europe. Harvard International Review, 2, 39-43. o.

Repečkienè, A. - Kvedaraitė, N. - Žvirelienè, R. - Glinskienė, R. (2012): Measures facilitating reduction of academic youth unemployment and transfer from educational institutions to labour market (Lithuanian case). Economics and Management, 17, 4, 1397-1409. o. 
Rodgers, G. (2007): Labour Market Flexibility and Decent Work. DESA Working Paper No. 47, United Nations Department of Economic and Social Affairs, New York.

Rogerson, R. - Shimer, R. - Wright, R. (2005): Search-Theoretic Models of the Labor Market: A Survey. Journal of Economic Literature, 43, 4, 959-988. o.

Roth, D. - Moffat, J. (2014): Cohort size and youth unemployment in Europe: a regional analysis. MAGKS Papers on Economics 201440, Philipps-Universität Marburg, Faculty of Business Administration and Economics, Department of Economics (Volkswirtschaftliche Abteilung).

Ruhs, M. - Vargas-Silva, C. (2015): The Labour Market Effects of Immigration. Migration Observatory policy primer, COMPAS, University of Oxford, 22/05/2015.

Sachs, A. - Smolny, W. (2015): Youth Unemployment in the OECD: The Role of Institutions. Journal of Economics and Statistics (Jahrbuecher fuer Nationaloekonomie und Statistik), De Gruyter, 235, 4-5, 403-417. o. DOI: https://doi.org/10.1515/jbnst-2015-4-505

Sajtos László - Mitev Ariel (2007): SPSS kutatási és adatelemzési kézikönyv. Alinea Kiadó, Budapest.

Samuelson, P. A. - Nordhaus W. D. (2012): Közgazdaságtan. Akadémiai Kiadó, Budapest, 19. kiadás, $672 \mathrm{o}$.

Sarfati, H. (2013): Coping with the unemployment crisis in Europe. International Labour Review, 1, 145-156. o.

Sávai Marianna - Kiss Gábor Dávid (2016): Hiányzó adatok kezelése pénzügyi idősoroknál afrikai devizaárfolyamok példáján. Statisztikai Szemle, 94, 7, 736-756. o.

Scarpetta, S. - Sonnet, A. - Manfredi, T. (2010): Rising youth unemployment during the crisis: how to prevent negative long-term consequences on a generation? OECD social, employment and migration working papers, 6. OECD Publishing. http://www.oecd.org/employment/youthforum/44986030.pdf

Scharle Ágota (2008): Foglalkoztatás, intézményrendszer és foglalkoztatáspolitika. In Kolosi Tamás - Tóth István György (szerk.): Társadalmi Riport 2008. TÁRKI, Budapest, 255289. o.

Schmerer, H.-J. (2014): Foreign direct investment and search unemployment: Theory and evidence. International Review of Economics and Finance, 30, C, 41-56. o.

Schumpeter, J. A. (1942): Capitalism, Socialism, Democracy. Routledge, Milton Park.

Sharkh, M. A. (2008): Are there optimal global configurations of labour market flexibility and security? Tackling the "flexicurity" oxymoron. Employment working paper no.15, International Labour Office, Geneva.

Sik Endre - Szeitl Blanka (2016): A prekariátus mint munkaerőpiaci csoport. Metszetek, 5, 3, 3-40. o.

Simai Mihály (2008): A világgazdaság a XXI. század forgatagában. Akadémiai Kiadó, Budapest.

Siyal, Ghamz-e-Ali - Ahmed, Adeel - Aziz, Arshad - Zaman, Khalid, (2013): The Long Run Effects between Unemployment and Economic Growth in Selected SAARC Countries, Economic Research Guardian, 3, 2, 70-85. o.

Skedinger, P. (2014): Effects of Payroll Tax Cuts for Young Workers. IFN Working Paper No. 1031, Research Institute of Industrial Economics, Stockholm.

Solga, H. - Protsch, P. - Ebner, C. - Brzinsky-Fay, C. (2014): The German vocational education and training system: Its institutional configuration, strengths, and challenges. WZB Discussion Paper, No. SP I 2014-502, Leibniz Information Centre for Economics, Berlin.

Soltwedel, R. - Dohse, D. - Krieger-Boden, C. (1999): EMU Challenges European Labor Markets. IMF Working Paper, No. WP/ 99/ 131.

Standing, G. (2011): The Precariat. The New Dangerous Class. Bloomsbury Academic, London, 2011. 
Statistics Netherlands (2015): Definitions. (Letöltve: 2015. 01. 29. http://www.cbs.nl/en$\mathrm{GB} / \mathrm{menu} / \mathrm{methoden/begrippen/default.htm)}$

Szépe András (2012): Prekariátus. Miért pont most és miért pont itt? Fordulat, 19, 3, 11-27. o. Tarnóczi Tibor - Fenyves Veronika - Bács Zoltán - Böcskei Elvira (2015): Versenyképesség és gazdasági etika. Vállalati teljesítmény elemzése panel regresszióval. Polgári Szemle, 11, 4-6. http://epa.oszk.hu/00800/00890/00061/EPA00890_polgari_szemle_2015_46 $705 . h$ tm

Tóthné Sikora Gizella (2002): Munkaerőpiaci ismeretek. Oktatási segédlet. Miskolci Egyetem Gazdaságtudományi Kar, Miskolc, 98 o.

Udvari Beáta - Kiss Gábor Dávid - Pontet Julianna (2016): Challenges of Missing Data in Analyses of Aid Activity: The Case of US Aid Activity. Bangladesh Development Studies, 39, 1-2, 1-25. o.

Udvari Beáta - Urbánné Mező Júlia (2015): Az ifjúsági munkanélküliség és a munkaerő- piaci rugalmasság összefüggései az Európai Unióban. Külgazdaság, 59, 11-12, 52-78. o.

Urbánné Mező Júlia - Udvari Beáta (2016): Munkapiaci rugalmasság és ifjúsági foglalkoztathatóság. Közgazdasági Szemle, 63, 4, 431-460. o.

U.S. Census Bureau (2002): Educational Attainment in the United States: 2002. https://www.census.gov/data/tables/2002/demo/educational-attainment/cps-detailedtables.html (Letöltve: 2017. 05. 31.)

U.S. Census Bureau (2016): Educational Attainment in the United States: 2016. https://www.census.gov/data/tables/2016/demo/education-attainment/cps-detailedtables.html (Letöltve: 2017. 05. 31.)

Vamossy, Domonkos F. (2014): Relationship between Youth Unemployment and Minimum Real Wage: An Empirical Analysis of the Hungarian Labor Market Using Multivariate Least Squares Regression Analysis. In Pál Michelberger (szerk.): Proceedings of FIKUSZ '14 Symposium for Young Researchers, 2014, Óbuda University, Budapest, 285-292. o.

Vargas-Silva, C. (2011): Migration and Development. Migration Observatory policy primer, COMPAS, University of Oxford, 26/10/2011.

Vergeer, R. - Kleinknecht, A. (2012): Do Flexible Labor Markets Indeed Reduce Unemployment? A Robustness Check. Review of Social Economy, 70, 4, 451-467. o.

Viebrock, E. - Clasen, J. (2014): Flexicurity - aktuális helyzetjelentés. Esély: Társadalom- és szociálpolitikai folyóirat, 25. évf., 1. sz., 18-44. o.

WEF (2014): The Global Competitiveness Report 2014-2015. World Economic Forum, Geneva.

Williamson, S. D. (2009): Makroökonómia. Osiris Kiadó, Budapest, 677. o.

Wilpert, B. (2009): Impact of globalization on human work. Safety Science, 47, 6, 727-732. o.

Wolbers, M. H. J. (2007): Patterns of Labour Market Entry. A Comparative Perspective on School-to-Work Transitions in 11 European Countries. Acta Sociologica, 50, 3, 189-210. o.

Wooldridge, J. M. (2010): Econometric Analysis of Cross Section and Panel Data. The MIT Press Cambridge, Massachusetts.

Zagler, M. (2009): Economic growth, structural change, and search unemployment. Journal of Economics, Springer, 96, 1, 63-78. o.

Zribi, T. EL G. - Temmi, H. - Zrelli, N. (2014): Can Labor Market Flexibility Affect Unemployment? A Panel Data Analysis. Journal of Human Resources Management and Labor Studies, 2, 1, 17-40. o. 


\section{MELLÉKLETEK}

\section{A TELJES IDÖSZAKRA (2000-2015) ELVÉGZETT PANEL REGRESSZIÓK EREDMÉNYEI (GRETL)}

1. A teljes foglalkoztatási rátát befolyásoló tényezők

\begin{tabular}{|c|c|c|c|c|c|}
\hline \multicolumn{6}{|c|}{$\begin{array}{l}\text { FE, } 364 \text { megfigyelés ( } 28 \text { ország, idősor hossza: } 13 \text { év) } \\
\text { Függő változó: teljes foglalkoztatási ráta }\end{array}$} \\
\hline & együttható & standard hiba & t-arány & p-érték & \\
\hline const & 1,77875 & 7,67738 & 0,2317 & 0,817 & \\
\hline min_wage & $-1,29993$ & 2,85832 & $-0,4548$ & 0,6496 & \\
\hline min_wage_1 & 1,42708 & 3,47481 & 0,4107 & 0,6816 & \\
\hline min_wage_2 & $-0,247825$ & 3,32553 & $-0,07452$ & 0,9406 & \\
\hline min_wage_3 & $-2,12753$ & 2,52922 & $-0,8412$ & 0,401 & \\
\hline tax_wedge & $-0,0143682$ & 0,030055 & $-0,4781$ & 0,633 & \\
\hline tax_wedge_1 & $-0,00601019$ & 0,03925 & $-0,1531$ & 0,8784 & \\
\hline tax_wedge_2 & 0,004133 & 0,038744 & 0,1067 & 0,9151 & \\
\hline tax_wedge_3 & $-0,00556433$ & 0,030127 & $-0,1847$ & 0,8536 & \\
\hline trade_union_dens & 0,006934 & 0,008073 & 0,8589 & 0,3911 & \\
\hline trade_union_dens_1 & $-0,0129468$ & 0,009634 & $-1,344$ & 0,1801 & \\
\hline trade_union_dens_2 & $-0,00488601$ & 0,010831 & $-0,4511$ & 0,6523 & \\
\hline trade_union_dens_3 & $-0,00274012$ & 0,009896 & $-0,2769$ & 0,7821 & \\
\hline part_timers & 0,106486 & 0,094955 & 1,121 & 0,2631 & \\
\hline part_timers_1 & $-0,143545$ & 0,111365 & $-1,289$ & 0,1985 & \\
\hline part_timers_2 & 0,224872 & 0,109149 & 2,06 & 0,0403 & $* *$ \\
\hline part_timers_3 & $-0,152221$ & 0,081044 & $-1,878$ & 0,0614 & $*$ \\
\hline invol_part_timers & $-0,0267267$ & 0,011994 & $-2,228$ & 0,0267 & $* *$ \\
\hline invol_part_timers_1 & 0,000254 & 0,013797 & 0,01841 & 0,9853 & \\
\hline invol_part_timers_2 & 0,025251 & 0,013296 & 1,899 & 0,0586 & $*$ \\
\hline invol_part_timers_3 & $-0,0178953$ & 0,011283 & $-1,586$ & 0,1139 & \\
\hline hours_worked & 0,333693 & 0,209819 & 1,59 & 0,1129 & \\
\hline hours_worked_1 & 0,02556 & 0,236786 & 0,1079 & 0,9141 & \\
\hline hours_worked_2 & $-0,163402$ & 0,20663 & $-0,7908$ & 0,4297 & \\
\hline hours_worked_3 & $-0,0438129$ & 0,155381 & $-0,2820$ & 0,7782 & \\
\hline temporary_emp & 0,190463 & 0,055274 & 3,446 & 0,0007 & $* * *$ \\
\hline temporary_emp_1 & $-0,179214$ & 0,072662 & $-2,466$ & 0,0143 & $* *$ \\
\hline temporary_emp_2 & 0,039372 & 0,065773 & 0,5986 & 0,5499 & \\
\hline temporary_emp_3 & $-0,0322466$ & 0,048875 & $-0,6598$ & 0,5099 & \\
\hline EPL_regular & 0,755881 & 0,300203 & 2,518 & 0,0124 & $* *$ \\
\hline EPL_regular_1 & $-0,357141$ & 0,347196 & $-1,029$ & 0,3045 & \\
\hline EPL_regular_2 & $-0,740145$ & 0,368654 & $-2,008$ & 0,0456 & $* *$ \\
\hline EPL_regular_3 & 0,606141 & 0,33522 & 1,808 & 0,0717 & $*$ \\
\hline EPL_temporary & 0,041898 & 0,154368 & 0,2714 & 0,7863 & \\
\hline EPL_temporary_1 & 0,140887 & 0,177595 & 0,7933 & 0,4283 & \\
\hline EPL_temporary_2 & 0,087358 & 0,185312 & 0,4714 & 0,6377 & \\
\hline EPL_temporary_3 & $-0,101530$ & 0,164518 & $-0,6171$ & 0,5377 & \\
\hline ALMP_expend & 0,914116 & 0,614284 & 1,488 & 0,1379 & \\
\hline ALMP_expend_1 & 0,048322 & 0,753431 & 0,06414 & 0,9489 & \\
\hline ALMP_expend_2 & $-0,673620$ & 0,778053 & $-0,8658$ & 0,3874 & \\
\hline ALMP_expend_3 & 0,7481 & 0,584853 & 1,279 & 0,2019 & \\
\hline PLMP_expend & $-1,30537$ & 0,265529 & $-4,916$ & $1,51 \mathrm{E}-06$ & $* * *$ \\
\hline PLMP_expend_1 & 0,719452 & 0,354452 & 2,03 & 0,0433 & $* *$ \\
\hline
\end{tabular}




\begin{tabular}{|c|c|c|c|c|c|}
\hline PLMP_expend_2 & 0,052761 & 0,368974 & 0,143 & 0,8864 & \\
\hline PLMP_expend_3 & 0,021194 & 0,290847 & 0,07287 & 0,942 & \\
\hline GDP_per_cap & $-0,000139567$ & $4,90 \mathrm{E}-05$ & $-2,849$ & 0,0047 & $* * *$ \\
\hline GDP_per_cap_1 & 0,00014 & $7,19 \mathrm{E}-05$ & 1,942 & 0,0532 & $*$ \\
\hline GDP_per_cap_2 & $3,64 \mathrm{E}-05$ & $7,38 \mathrm{E}-05$ & 0,4927 & 0,6226 & \\
\hline GDP_per_cap_3 & $-7,65108 \mathrm{e}-05$ & $5,17 \mathrm{E}-05$ & $-1,479$ & 0,1403 & \\
\hline GDP_growth & 0,134929 & 0,021688 & 6,221 & $1,81 \mathrm{E}-09$ & $* * *$ \\
\hline GDP_growth_1 & $-0,0376575$ & 0,034823 & $-1,081$ & 0,2805 & \\
\hline GDP_growth_2 & $-0,0779581$ & 0,033851 & $-2,303$ & 0,022 & $* *$ \\
\hline GDP_growth_3 & $-0,00973782$ & 0,022308 & $-0,4365$ & 0,6628 & \\
\hline HICP & 0,085848 & 0,034939 & 2,457 & 0,0146 & $* *$ \\
\hline HICP_1 & $-0,168752$ & 0,059996 & $-2,813$ & 0,0053 & $* * *$ \\
\hline HICP_2 & 0,191149 & 0,066764 & 2,863 & 0,0045 & $* * *$ \\
\hline HICP_3 & $-0,0741848$ & 0,041516 & $-1,787$ & 0,075 & $*$ \\
\hline total_emp_rate_1 & 0,970069 & 0,058309 & 16,64 & $1,45 \mathrm{E}-43$ & $* * *$ \\
\hline total_emp_rate_2 & $-0,124533$ & 0,072685 & $-1,713$ & 0,0878 & $*$ \\
\hline total_emp_rate_3 & $-0,0339284$ & 0,052925 & $-0,6411$ & 0,522 & \\
\hline Mean dependent var & 53,45235 & & S.D. dependent & & 5,944947 \\
\hline Sum squared resid & 131,8906 & & S.E. of regressi & & 0,690029 \\
\hline LSDV R-squared & 0,98972 & & Within R-squar & & 0,920379 \\
\hline LSDV F(86, 277) & 310,086 & & P-value(F) & & $7,10 \mathrm{E}-235$ \\
\hline Log-likelihood & $-331,7307$ & & Akaike criterio & & 837,4614 \\
\hline Schwarz criterion & 1176,514 & & Hannan-Quinn & & 972,2191 \\
\hline rho & $-0,012122$ & & Durbin-Watson & & 1,876893 \\
\hline \multicolumn{6}{|c|}{$\begin{array}{l}\text { Joint test on named regressors - } \\
\text { Test statistic: } \mathrm{F}(59,277)=54,2712 \\
\text { with p-value }=\mathrm{P}(\mathrm{F}(59,277)>54,2712)=6,68874 \mathrm{e}-122\end{array}$} \\
\hline \multicolumn{6}{|c|}{$\begin{array}{l}\text { Test for differing group intercepts - } \\
\text { Null hypothesis: The groups have a common intercept } \\
\text { Test statistic: } F(27,277)=2,06502 \\
\text { with p-value }=\mathrm{P}(\mathrm{F}(27,277)>2,06502)=0,00199175\end{array}$} \\
\hline
\end{tabular}

Megjegyzés: * jelöli a 10 százalékos, ** az 5 százalékos, *** pedig az 1 százalékos szinten szignifikáns hatással bíró változókat.

Forrás: saját szerkesztés.

2. A teljes munkanélküliségi rátát befolyásoló tényezők

\begin{tabular}{|c|c|c|c|c|c|}
\hline \multicolumn{6}{|c|}{$\begin{array}{l}\text { FE, } 364 \text { megfigyelés ( } 28 \text { ország, idősor hossza: } 13 \text { év) } \\
\text { Függő változó: teljes munkanélküliségi ráta }\end{array}$} \\
\hline & együttható & standard hiba & t-arány & p-érték & \\
\hline const & $-5,65115$ & 9,17682 & $-0,6158$ & 0,5385 & \\
\hline min_wage & 3,11486 & 3,25725 & 0,9563 & 0,3398 & \\
\hline min_wage_1 & $-1,52658$ & 3,96815 & $-0,3847$ & 0,7007 & \\
\hline min_wage_2 & $-0,864976$ & 3,79309 & $-0,2280$ & 0,8198 & \\
\hline min_wage_3 & 0,713818 & 2,88795 & 0,2472 & 0,805 & \\
\hline tax_wedge & $-0,0134963$ & 0,033773 & $-0,3996$ & 0,6897 & \\
\hline tax_wedge_1 & 0,010352 & 0,044708 & 0,2315 & 0,8171 & \\
\hline tax_wedge_2 & 0,035271 & 0,043982 & 0,8019 & 0,4233 & \\
\hline tax_wedge_3 & 0,002935 & 0,034151 & 0,08594 & 0,9316 & \\
\hline trade_union_dens & 0,00187 & 0,009265 & 0,2018 & 0,8402 & \\
\hline trade_union_dens_1 & $-0,00304433$ & 0,010913 & $-0,2790$ & 0,7805 & \\
\hline trade_union_dens_2 & 0,005149 & 0,012375 & 0,416 & 0,6777 & \\
\hline trade_union_dens_3 & $-0,00710738$ & 0,011291 & $-0,6295$ & 0,5295 & \\
\hline
\end{tabular}




\begin{tabular}{|c|c|c|c|c|c|}
\hline part_timers & 0,027238 & 0,107856 & 0,2525 & 0,8008 & \\
\hline part_timers_1 & $-0,0645436$ & 0,126798 & $-0,5090$ & 0,6111 & \\
\hline part_timers_2 & $-0,201124$ & 0,123478 & $-1,629$ & 0,1045 & \\
\hline part_timers_3 & 0,201532 & 0,092707 & 2,174 & 0,0306 & $* *$ \\
\hline invol_part_timers & 0,040889 & 0,013471 & 3,035 & 0,0026 & $* * *$ \\
\hline invol_part_timers_1 & $-0,0153999$ & 0,015834 & $-0,9726$ & 0,3316 & \\
\hline invol_part_timers_2 & $-0,0298816$ & 0,015431 & $-1,936$ & 0,0538 & $*$ \\
\hline invol_part_timers_3 & 0,030886 & 0,013117 & 2,355 & 0,0192 & $* *$ \\
\hline hours_worked & $-0,299400$ & 0,238332 & $-1,256$ & 0,2101 & \\
\hline hours_worked_1 & 0,103134 & 0,270747 & 0,3809 & 0,7036 & \\
\hline hours_worked_2 & 0,067219 & 0,235662 & 0,2852 & 0,7757 & \\
\hline hours_worked_3 & 0,294961 & 0,177312 & 1,664 & 0,0973 & $*$ \\
\hline temporary_emp & $-0,134391$ & 0,063178 & $-2,127$ & 0,0343 & $* *$ \\
\hline temporary_emp_1 & 0,06352 & 0,081939 & 0,7752 & 0,4389 & \\
\hline temporary_emp_2 & 0,025386 & 0,074789 & 0,3394 & 0,7345 & \\
\hline temporary_emp_3 & 0,012814 & 0,056394 & 0,2272 & 0,8204 & \\
\hline EPL_regular & $-0,650530$ & 0,340002 & $-1,913$ & 0,0567 & $*$ \\
\hline EPL_regular_1 & 0,501876 & 0,395782 & 1,268 & 0,2058 & \\
\hline EPL_regular_2 & 0,998845 & 0,42276 & 2,363 & 0,0188 & $* *$ \\
\hline EPL_regular_3 & $-0,552000$ & 0,383179 & $-1,441$ & 0,1508 & \\
\hline EPL_temporary & $-0,0660781$ & 0,17661 & $-0,3741$ & 0,7086 & \\
\hline EPL_temporary_1 & $-0,395833$ & 0,201548 & $-1,964$ & 0,0505 & $*$ \\
\hline EPL_temporary_2 & $-0,0846248$ & 0,211387 & $-0,4003$ & 0,6892 & \\
\hline EPL_temporary_3 & 0,160926 & 0,187789 & 0,857 & 0,3922 & \\
\hline ALMP_expend & $-1,27835$ & 0,695034 & $-1,839$ & 0,0669 & $*$ \\
\hline ALMP_expend_1 & 0,693808 & 0,856625 & 0,8099 & 0,4187 & \\
\hline ALMP_expend_2 & 0,406184 & 0,888316 & 0,4573 & 0,6478 & \\
\hline ALMP_expend_3 & $-0,444272$ & 0,668587 & $-0,6645$ & 0,5069 & \\
\hline PLMP_expend & 1,60555 & 0,302381 & 5,31 & $2,26 \mathrm{E}-07$ & $* * *$ \\
\hline PLMP_expend_1 & $-0,533460$ & 0,402473 & $-1,325$ & 0,1861 & \\
\hline PLMP_expend_2 & $-0,128672$ & 0,41659 & $-0,3089$ & 0,7577 & \\
\hline PLMP_expend_3 & 0,305989 & 0,332238 & 0,921 & 0,3579 & \\
\hline GDP_per_cap & $9,45 \mathrm{E}-05$ & $5,57 \mathrm{E}-05$ & 1,696 & 0,0911 & $*$ \\
\hline GDP_per_cap_1 & $-4,50533 e-05$ & $8,17 \mathrm{E}-05$ & $-0,5514$ & 0,5818 & \\
\hline GDP_per_cap_2 & $-9,04038 \mathrm{e}-05$ & $8,37 \mathrm{E}-05$ & $-1,080$ & 0,281 & \\
\hline GDP_per_cap_3 & 0,000121 & $5,90 \mathrm{E}-05$ & 2,06 & 0,0403 & $* *$ \\
\hline GDP_growth & $-0,147843$ & 0,02475 & $-5,973$ & 7,11E-09 & $* * *$ \\
\hline GDP_growth_1 & 0,022737 & 0,039406 & 0,577 & 0,5644 & \\
\hline GDP_growth_2 & 0,139147 & 0,038826 & 3,584 & 0,0004 & $* * *$ \\
\hline GDP_growth_3 & $-0,0599340$ & 0,026136 & $-2,293$ & 0,0226 & $* *$ \\
\hline HICP & $-0,0280870$ & 0,039828 & $-0,7052$ & 0,4813 & \\
\hline HICP_1 & 0,208715 & 0,068473 & 3,048 & 0,0025 & $* * *$ \\
\hline HICP_2 & $-0,262029$ & 0,0758 & $-3,457$ & 0,0006 & $* * *$ \\
\hline HICP_3 & 0,103553 & 0,047352 & 2,187 & 0,0296 & $* *$ \\
\hline total_unemp_rate_1 & 1,00893 & 0,05748 & 17,55 & $6,93 \mathrm{E}-47$ & $* * *$ \\
\hline total_unemp_rate_2 & $-0,180597$ & 0,072811 & $-2,480$ & 0,0137 & $* *$ \\
\hline total_unemp_rate_3 & $-0,111209$ & 0,049705 & $-2,237$ & 0,0261 & $* *$ \\
\hline Mean dependent var & 8,975862 & \multicolumn{3}{|c|}{ S.D. dependent var } & 4,262773 \\
\hline Sum squared resid & 171,7974 & \multicolumn{3}{|c|}{ S.E. of regression } & 0,787532 \\
\hline LSDV R-squared & 0,973955 & \multicolumn{3}{|c|}{ Within R-squared } & 0,948072 \\
\hline LSDV F(86, 277) & 120,4466 & \multicolumn{3}{|c|}{ P-value(F) } & $3,00 \mathrm{E}-179$ \\
\hline Log-likelihood & $-379,8411$ & \multicolumn{3}{|c|}{ Akaike criterion } & 933,6821 \\
\hline Schwarz criterion & 1272,735 & \multicolumn{3}{|c|}{ Hannan-Quinn } & 1068,44 \\
\hline rho & 0,014145 & \multicolumn{3}{|c|}{ Durbin-Watson } & 1,826082 \\
\hline
\end{tabular}




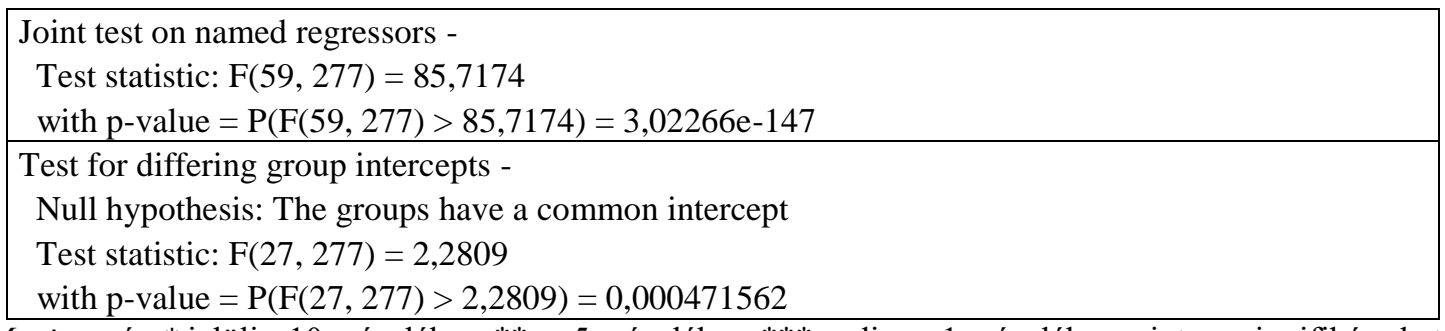

Megjegyzés: * jelöli a 10 százalékos, ** az 5 százalékos, *** pedig az 1 százalékos szinten szignifikáns hatással bíró változókat.

Forrás: saját szerkesztés.

3. Az ifjúsági foglalkoztatási rátát befolyásoló tényezők

\begin{tabular}{|c|c|c|c|c|c|}
\hline \multicolumn{6}{|c|}{$\begin{array}{l}\text { FE, } 392 \text { megfigyelés ( } 28 \text { ország, idősor hossza: } 14 \text { év) } \\
\text { Függő változó: ifjúsági foglalkoztatási ráta }\end{array}$} \\
\hline & együttható & standard hiba & t-arány & p-érték & \\
\hline const & $-14,7679$ & 12,5148 & $-1,180$ & 0,2389 & \\
\hline min_wage & $-0,0279819$ & 5,31502 & $-0,005265$ & 0,9958 & \\
\hline min_wage_1 & 1,84088 & 6,31749 & 0,2914 & 0,7709 & \\
\hline min_wage_2 & 2,53603 & 4,66793 & 0,5433 & 0,5873 & \\
\hline tax_wedge & 0,006423 & 0,057297 & 0,1121 & 0,9108 & \\
\hline tax_wedge_1 & 0,004259 & 0,074315 & 0,05732 & 0,9543 & \\
\hline tax_wedge_2 & $-0,0353575$ & 0,056224 & $-0,6289$ & 0,5299 & \\
\hline trade_union_dens & $-0,0321387$ & 0,015147 & $-2,122$ & 0,0346 & $* *$ \\
\hline trade_union_dens_1 & 0,026987 & 0,01858 & 1,452 & 0,1473 & \\
\hline trade_union_dens_2 & 0,013686 & 0,018441 & 0,7421 & 0,4585 & \\
\hline part_timers & 0,308685 & 0,174272 & 1,771 & 0,0775 & $*$ \\
\hline part_timers_1 & $-0,668380$ & 0,210254 & $-3,179$ & 0,0016 & $* * *$ \\
\hline part_timers_2 & 0,376557 & 0,157743 & 2,387 & 0,0176 & $* *$ \\
\hline invol_part_timers & $-0,0669127$ & 0,022394 & $-2,988$ & 0,003 & **** \\
\hline invol_part_timers_1 & 0,036657 & 0,02649 & 1,384 & 0,1674 & \\
\hline invol_part_timers_2 & 0,004858 & 0,021758 & 0,2233 & 0,8235 & \\
\hline hours_worked & 0,428615 & 0,361624 & 1,185 & 0,2368 & \\
\hline hours_worked_1 & $-0,103052$ & 0,409066 & $-0,2519$ & 0,8013 & \\
\hline hours_worked_2 & 0,071206 & 0,305774 & 0,2329 & 0,816 & \\
\hline temporary_emp & 0,54192 & 0,097848 & 5,538 & $6,37 \mathrm{E}-08$ & $* * *$ \\
\hline temporary_emp_1 & $-0,323712$ & 0,12464 & $-2,597$ & 0,0098 & $* * *$ \\
\hline temporary_emp_2 & $-0,106349$ & 0,093314 & $-1,140$ & 0,2553 & \\
\hline EPL_regular & 1,09798 & 0,551922 & 1,989 & 0,0475 & $* *$ \\
\hline EPL_regular_1 & $-0,734639$ & 0,66264 & $-1,109$ & 0,2684 & \\
\hline EPL_regular_2 & $-0,307072$ & 0,59065 & $-0,5199$ & 0,6035 & \\
\hline EPL_temporary & $-1,16010$ & 0,286264 & $-4,053$ & $6,37 \mathrm{E}-05$ & $* * *$ \\
\hline EPL_temporary_1 & 1,13734 & 0,348911 & 3,26 & 0,0012 & $* * *$ \\
\hline EPL_temporary_2 & $-0,0971284$ & 0,300051 & $-0,3237$ & 0,7464 & \\
\hline ALMP_expend & 1,37014 & 1,11568 & 1,228 & 0,2203 & \\
\hline ALMP_expend_1 & $-0,742964$ & 1,41688 & $-0,5244$ & 0,6004 & \\
\hline ALMP_expend_2 & 0,829011 & 1,11577 & 0,743 & 0,458 & \\
\hline PLMP_expend & $-2,71383$ & 0,495534 & $-5,477$ & $8,78 \mathrm{E}-08$ & $* * *$ \\
\hline PLMP_expend_1 & 2,18885 & 0,666394 & 3,285 & 0,0011 & $* * *$ \\
\hline PLMP_expend_2 & $-0,724819$ & 0,531393 & $-1,364$ & 0,1735 & \\
\hline GDP_per_cap & $-0,000179803$ & $9,43 \mathrm{E}-05$ & $-1,907$ & 0,0574 & $*$ \\
\hline GDP_per_cap_1 & 0,000309 & 0,000138 & 2,231 & 0,0264 & $* *$ \\
\hline GDP_per_cap_2 & $-0,000153905$ & 9,83E-05 & $-1,565$ & 0,1185 & \\
\hline GDP_growth & 0,192795 & 0,041266 & 4,672 & $4,40 \mathrm{E}-06$ & $* * *$ \\
\hline GDP_growth_1 & $-0,0906560$ & 0,060639 & $-1,495$ & 0,1359 & \\
\hline
\end{tabular}




\begin{tabular}{|c|c|c|c|c|c|}
\hline GDP_growth_2 & $-0,0882644$ & 0,040583 & $-2,175$ & 0,0304 & $* *$ \\
\hline HICP & 0,100057 & 0,065106 & 1,537 & 0,1253 & \\
\hline HICP_1 & $-0,110197$ & 0,111458 & $-0,9887$ & 0,3236 & \\
\hline HICP_2 & 0,041584 & 0,075311 & 0,5522 & 0,5812 & \\
\hline youth_emp_rate_1 & 0,968107 & 0,054552 & 17,75 & $1,54 \mathrm{E}-49$ & $* * *$ \\
\hline youth_emp_rate_2 & $-0,148305$ & 0,053519 & $-2,771$ & 0,0059 & $* * *$ \\
\hline Mean dependent var & \multicolumn{2}{|l|}{33,97683} & \multicolumn{2}{|c|}{ S.D. dependent var } & 12,80189 \\
\hline Sum squared resid & \multicolumn{2}{|l|}{630,4229} & \multicolumn{2}{|c|}{ S.E. of regression } & 1,403592 \\
\hline LSDV R-squared & \multicolumn{2}{|l|}{0,990162} & \multicolumn{2}{|c|}{ Within R-squared } & 0,901979 \\
\hline $\operatorname{LSDV} F(71,320)$ & \multicolumn{2}{|l|}{453,6186} & \multicolumn{2}{|l|}{ P-value(F) } & $1,20 \mathrm{E}-283$ \\
\hline Log-likelihood & \multicolumn{2}{|l|}{$-649,3492$} & \multicolumn{2}{|l|}{ Akaike criterion } & 1442,698 \\
\hline Schwarz criterion & \multicolumn{2}{|l|}{1728,629} & & 1556,02 \\
\hline rho & \multicolumn{2}{|l|}{$-0,064748$} & Hannan-Quinn & Durbin-Watson & 1,946021 \\
\hline \multicolumn{6}{|c|}{$\begin{array}{l}\text { Joint test on named regressors - } \\
\text { Test statistic: } \mathrm{F}(44,320)=66,9228 \\
\text { with p-value }=\mathrm{P}(\mathrm{F}(44,320)>66,9228)=7,16702 \mathrm{e}-136\end{array}$} \\
\hline \multicolumn{6}{|c|}{$\begin{array}{l}\text { Test for differing group intercepts - } \\
\text { Null hypothesis: The groups have a common intercept } \\
\text { Test statistic: } \mathrm{F}(27,320)=2,37016 \\
\text { with p-value }=\mathrm{P}(\mathrm{F}(27,320)>2,37016)=0,000222278\end{array}$} \\
\hline
\end{tabular}

Megjegyzés: * jelöli a 10 százalékos, ** az 5 százalékos, *** pedig az 1 százalékos szinten szignifikáns hatással bíró változókat.

Forrás: saját szerkesztés.

4. Az ifjúsági munkanélküliségi rátát befolyásoló tényezők

\begin{tabular}{|c|c|c|c|c|c|}
\hline \multicolumn{6}{|c|}{$\begin{array}{l}\text { FE, } 392 \text { megfigyelés ( } 28 \text { ország, idősor hossza: } 14 \text { év) } \\
\text { Függő változó: ifjúsági munkanélküliségi ráta }\end{array}$} \\
\hline & együttható & standard hiba & t-arány & p-érték & \\
\hline const & 25,62 & 19,9146 & 1,286 & 0,1992 & \\
\hline min_wage & 3,53492 & 8,09807 & 0,4365 & 0,6628 & \\
\hline min_wage_1 & $-9,87193$ & 9,59412 & $-1,029$ & 0,3043 & \\
\hline min_wage_2 & $-3,97813$ & 7,07978 & $-0,5619$ & 0,5746 & \\
\hline tax_wedge & $-0,0953466$ & 0,08682 & $-1,098$ & 0,2729 & \\
\hline tax_wedge_1 & 0,144897 & 0,11332 & 1,279 & 0,2019 & \\
\hline tax_wedge_2 & 0,029999 & 0,086192 & 0,348 & 0,728 & \\
\hline trade_union_dens & 0,067547 & 0,023298 & 2,899 & 0,004 & $* * *$ \\
\hline trade_union_dens_1 & $-0,0609394$ & 0,028521 & $-2,137$ & 0,0334 & $* *$ \\
\hline trade_union_dens_2 & $-0,0165712$ & 0,028202 & $-0,5876$ & 0,5572 & \\
\hline part_timers & 0,05075 & 0,265062 & 0,1915 & 0,8483 & \\
\hline part_timers_1 & $-0,0457884$ & 0,316582 & $-0,1446$ & 0,8851 & \\
\hline part_timers_2 & $-0,218687$ & 0,240102 & $-0,9108$ & 0,3631 & \\
\hline invol_part_timers & 0,192356 & 0,033695 & 5,709 & $2,60 \mathrm{E}-08$ & $* * *$ \\
\hline invol_part_timers_1 & $-0,0851397$ & 0,040995 & $-2,077$ & 0,0386 & $* *$ \\
\hline invol_part_timers_2 & $9,05 \mathrm{E}-05$ & 0,034051 & 0,002658 & 0,9979 & \\
\hline hours_worked & $-0,117823$ & 0,549983 & $-0,2142$ & 0,8305 & \\
\hline hours_worked_1 & $-0,250559$ & 0,622354 & $-0,4026$ & 0,6875 & \\
\hline hours_worked_2 & 0,102065 & 0,457921 & 0,2229 & 0,8238 & \\
\hline temporary_emp & $-0,281395$ & 0,146146 & $-1,925$ & 0,0551 & $*$ \\
\hline temporary_emp_1 & $-0,0481934$ & 0,186934 & $-0,2578$ & 0,7967 & \\
\hline temporary_emp_2 & 0,172168 & 0,140342 & 1,227 & 0,2208 & \\
\hline EPL_regular & $-2,28340$ & 0,840695 & $-2,716$ & 0,007 & $* * *$ \\
\hline EPL_regular_1 & 0,769415 & 1,01469 & 0,7583 & 0,4488 & \\
\hline EPL_regular_2 & 0,283291 & 0,907889 & 0,312 & 0,7552 & \\
\hline
\end{tabular}




\begin{tabular}{|c|c|c|c|c|c|}
\hline EPL_temporary & 1,32476 & 0,434385 & 3,05 & 0,0025 & $* * *$ \\
\hline EPL_temporary_1 & $-1,61504$ & 0,528952 & $-3,053$ & 0,0025 & $* * *$ \\
\hline EPL_temporary_2 & 0,183559 & 0,454183 & 0,4042 & 0,6864 & \\
\hline ALMP_expend & $-4,51168$ & 1,70098 & $-2,652$ & 0,0084 & $* * *$ \\
\hline ALMP_expend_1 & 2,1283 & 2,16831 & 0,9815 & 0,3271 & \\
\hline ALMP_expend_2 & $-0,575955$ & 1,70278 & $-0,3382$ & 0,7354 & \\
\hline PLMP_expend & 2,84718 & 0,755748 & 3,767 & 0,0002 & $* * *$ \\
\hline PLMP_expend_1 & $-0,937893$ & 1,0043 & $-0,9339$ & 0,3511 & \\
\hline PLMP_expend_2 & 0,752865 & 0,810909 & 0,9284 & 0,3539 & \\
\hline GDP_per_cap & 0,000178 & 0,000143 & 1,243 & 0,2148 & \\
\hline GDP_per_cap_1 & $3,69 \mathrm{E}-05$ & 0,000211 & 0,1751 & 0,8611 & \\
\hline GDP_per_cap_2 & $-5,65398 \mathrm{e}-05$ & 0,00015 & $-0,3763$ & 0,7069 & \\
\hline GDP_growth & $-0,364871$ & 0,062538 & $-5,834$ & $1,32 \mathrm{E}-08$ & $* * *$ \\
\hline GDP_growth_1 & 0,109849 & 0,093044 & 1,181 & 0,2386 & \\
\hline GDP_growth_2 & 0,140477 & 0,064067 & 2,193 & 0,0291 & $* *$ \\
\hline $\mathrm{HICP}$ & 0,088215 & 0,098461 & 0,8959 & 0,371 & \\
\hline HICP_1 & 0,21717 & 0,168203 & 1,291 & 0,1976 & \\
\hline HICP_2 & $-0,254150$ & 0,113636 & $-2,237$ & 0,026 & $* *$ \\
\hline youth_unemp_rate_1 & 0,834644 & 0,053309 & 15,66 & $2,03 \mathrm{E}-41$ & $* * *$ \\
\hline youth_unemp_rate_2 & $-0,191188$ & 0,049557 & $-3,858$ & 0,0001 & $* * *$ \\
\hline Mean dependent var & 20,63155 & & S.D. dependent & & 9,749676 \\
\hline Sum squared resid & 1460,493 & & S.E. of regressi & & 2,136362 \\
\hline LSDV R-squared & 0,960705 & & Within R-squar & & 0,911523 \\
\hline $\operatorname{LSDV} F(71,320)$ & 110,1892 & & P-value(F) & & $7,10 \mathrm{E}-188$ \\
\hline Log-likelihood & $-814,0163$ & & Akaike criterior & & 1772,033 \\
\hline Schwarz criterion & 2057,964 & & Hannan-Quinn & & 1885,355 \\
\hline rho & $-0,020493$ & & Durbin-Watson & & 1,881636 \\
\hline \multicolumn{6}{|c|}{$\begin{array}{l}\text { Joint test on named regressors - } \\
\text { Test statistic: } \mathrm{F}(44,320)=74,9259 \\
\text { with p-value }=\mathrm{P}(\mathrm{F}(44,320)>74,9259)=6,80375 \mathrm{e}-143\end{array}$} \\
\hline \multicolumn{6}{|c|}{$\begin{array}{l}\text { Test for differing group intercepts - } \\
\text { Null hypothesis: The groups have a common intercept } \\
\text { Test statistic: } \mathrm{F}(27,320)=3,24283 \\
\text { with p-value }=\mathrm{P}(\mathrm{F}(27,320)>3,24283)=3,35951 \mathrm{e}-007\end{array}$} \\
\hline
\end{tabular}

Megjegyzés: * jelöli a 10 százalékos, ** az 5 százalékos, *** pedig az 1 százalékos szinten szignifikáns hatással bíró változókat.

Forrás: saját szerkesztés.

5. Az ifjúsági munkanélküliségi arányt befolyásoló tényezők

\begin{tabular}{|c|c|c|c|c|c|}
\hline \multicolumn{6}{|c|}{$\begin{array}{l}\text { FE, } 392 \text { megfigyelés ( } 28 \text { ország, idősor hossza: } 14 \text { év } \\
\text { Függő változó: ifjúsági munkanélküliségi arány }\end{array}$} \\
\hline & együttható & standard hiba & t-arány & p-érték & \\
\hline const & 2,14272 & 7,44838 & 0,2877 & 0,7738 & \\
\hline min_wage & 4,38416 & 3,11701 & 1,407 & 0,1605 & \\
\hline min_wage_1 & $-4,97927$ & 3,69781 & $-1,347$ & 0,1791 & \\
\hline min_wage_2 & $-0,869270$ & 2,72351 & $-0,3192$ & 0,7498 & \\
\hline tax_wedge & $-0,0102989$ & 0,033504 & $-0,3074$ & 0,7587 & \\
\hline tax_wedge_1 & 0,02476 & 0,043631 & 0,5675 & 0,5708 & \\
\hline tax_wedge_2 & 0,013058 & 0,032956 & 0,3962 & 0,6922 & \\
\hline trade_union_dens & 0,036001 & 0,008929 & 4,032 & $6,92 \mathrm{E}-05$ & $* * *$ \\
\hline trade_union_dens_1 & $-0,0265290$ & 0,011042 & $-2,402$ & 0,0169 & $* *$ \\
\hline trade_union_dens_2 & 0,004117 & 0,010873 & 0,3786 & 0,7052 & \\
\hline part_timers & 0,186695 & 0,101902 & 1,832 & 0,0679 & $*$ \\
\hline
\end{tabular}




\begin{tabular}{|c|c|c|c|c|c|}
\hline part_timers_1 & $-0,162081$ & 0,12196 & $-1,329$ & 0,1848 & \\
\hline part_timers_2 & $-0,0413245$ & 0,092807 & $-0,4453$ & 0,6564 & \\
\hline invol_part_timers & 0,068629 & 0,012857 & 5,338 & $1,79 \mathrm{E}-07$ & $* * *$ \\
\hline invol_part_timers_1 & $-0,0318257$ & 0,015762 & $-2,019$ & 0,0443 & $* *$ \\
\hline invol_part_timers_2 & $-0,00470653$ & 0,012873 & $-0,3656$ & 0,7149 & \\
\hline hours_worked & 0,080272 & 0,21169 & 0,3792 & 0,7048 & \\
\hline hours_worked_1 & $-0,145090$ & 0,239124 & $-0,6068$ & 0,5444 & \\
\hline hours_worked_2 & 0,047604 & 0,175578 & 0,2711 & 0,7865 & \\
\hline temporary_emp & $-0,00121623$ & 0,05581 & $-0,02179$ & 0,9826 & \\
\hline temporary_emp_1 & $-0,133435$ & 0,071648 & $-1,862$ & 0,0635 & $*$ \\
\hline temporary_emp_2 & 0,078165 & 0,053847 & 1,452 & 0,1476 & \\
\hline EPL_regular & $-0,448447$ & 0,320834 & $-1,398$ & 0,1632 & \\
\hline EPL_regular_1 & 0,217195 & 0,386378 & 0,5621 & 0,5744 & \\
\hline EPL_regular_2 & 0,405401 & 0,343709 & 1,179 & 0,2391 & \\
\hline EPL_temporary & 0,301392 & 0,167289 & 1,802 & 0,0725 & $*$ \\
\hline EPL_temporary_1 & $-0,470812$ & 0,201798 & $-2,333$ & 0,0203 & $* *$ \\
\hline EPL_temporary_2 & 0,210844 & 0,173242 & 1,217 & 0,2245 & \\
\hline ALMP_expend & $-1,88575$ & 0,654216 & $-2,882$ & 0,0042 & $* * *$ \\
\hline ALMP_expend_1 & 1,08123 & 0,838228 & 1,29 & 0,198 & \\
\hline ALMP_expend_2 & $-0,168910$ & 0,658987 & $-0,2563$ & 0,7979 & \\
\hline PLMP_expend & 1,33511 & 0,290637 & 4,594 & $6,27 \mathrm{E}-06$ & $* * *$ \\
\hline PLMP_expend_1 & $-0,620929$ & 0,390356 & $-1,591$ & 0,1127 & \\
\hline PLMP_expend_2 & $-0,191739$ & 0,315857 & $-0,6070$ & 0,5443 & \\
\hline GDP_per_cap & $-2,29385 \mathrm{e}-05$ & $5,51 \mathrm{E}-05$ & $-0,4160$ & 0,6777 & \\
\hline GDP_per_cap_1 & \begin{tabular}{|l|}
0,000106 \\
\end{tabular} & $8,10 \mathrm{E}-05$ & 1,312 & 0,1905 & \\
\hline GDP_per_cap_2 & $-4,35293 \mathrm{e}-05$ & $5,78 \mathrm{E}-05$ & $-0,7532$ & 0,4519 & \\
\hline GDP_growth & $-0,0912043$ & 0,024039 & $-3,794$ & 0,0002 & $* * *$ \\
\hline GDP_growth_1 & 0,006499 & 0,035181 & 0,1847 & 0,8536 & \\
\hline GDP_growth_2 & 0,057516 & 0,024015 & 2,395 & 0,0172 & $* *$ \\
\hline HICP & 0,03143 & 0,037441 & 0,8395 & 0,4018 & \\
\hline HICP_1 & 0,09037 & 0,064417 & 1,403 & 0,1616 & \\
\hline HICP_2 & $-0,106006$ & 0,043672 & $-2,427$ & 0,0158 & $* *$ \\
\hline youth_unemp_ratio_1 & 0,760707 & 0,05203 & 14,62 & $1,97 \mathrm{E}-37$ & $* * *$ \\
\hline youth_unemp_ratio_2 & $-0,0893293$ & 0,048146 & $-1,855$ & 0,0645 & $*$ \\
\hline Mean dependent var & 8,051666 & & S.D. dependent & & 3,179868 \\
\hline Sum squared resid & 215,8874 & & S.E. of regressic & & 0,82137 \\
\hline LSDV R-squared & 0,945395 & & Within R-squar & & 0,881127 \\
\hline LSDV F(71, 320) & 78,03196 & & P-value $(F)$ & & $3,00 \mathrm{E}-165$ \\
\hline Log-likelihood & $-439,3089$ & & Akaike criterior & & 1022,618 \\
\hline Schwarz criterion & 1308,549 & & Hannan-Quinn & & 1135,94 \\
\hline rho & $-0,015129$ & & Durbin-Watson & & 1,828969 \\
\hline \multicolumn{6}{|c|}{$\begin{array}{l}\text { Joint test on named regressors - } \\
\text { Test statistic: } \mathrm{F}(44,320)=53,9081 \\
\text { with p-value }=\mathrm{P}(\mathrm{F}(44,320)>53,9081)=1,1103 \mathrm{e}-122\end{array}$} \\
\hline \multicolumn{6}{|c|}{$\begin{array}{l}\text { Test for differing group intercepts - } \\
\text { Null hypothesis: The groups have a common intercept } \\
\text { Test statistic: } \mathrm{F}(27,320)=3,15349 \\
\text { with p-value }=\mathrm{P}(\mathrm{F}(27,320)>3,15349)=6,66534 \mathrm{e}-007\end{array}$} \\
\hline
\end{tabular}

Megjegyzés: * jelöli a 10 százalékos, ** az 5 százalékos, *** pedig az 1 százalékos szinten szignifikáns hatással bíró változókat.

Forrás: saját szerkesztés. 


\section{A NEET rátát befolyásoló tényezők}

\begin{tabular}{|c|c|c|c|c|c|}
\hline \multicolumn{6}{|c|}{$\begin{array}{l}\text { FE, } 420 \text { megfigyelés ( } 28 \text { ország, idősor hossza: } 15 \text { év) } \\
\text { Függő változó: NEET ráta }\end{array}$} \\
\hline & együttható & standard hiba & t-arány & p-érték & \\
\hline const & 2,22194 & 7,90892 & 0,2809 & 0,7789 & \\
\hline min_wage & 26,3797 & 3,66816 & 7,192 & $3,69 \mathrm{E}-12$ & $* * *$ \\
\hline min_wage_1 & $-18,1884$ & 3,53782 & $-5,141$ & $4,47 \mathrm{E}-07$ & $* * *$ \\
\hline tax_wedge & $-0,00410278$ & 0,04245 & $-0,09665$ & 0,9231 & \\
\hline tax_wedge_1 & 0,067853 & 0,041451 & 1,637 & 0,1025 & \\
\hline trade_union_dens & 0,032257 & 0,011377 & 2,835 & 0,0048 & $* * *$ \\
\hline trade_union_dens_1 & $-0,0193751$ & 0,012549 & $-1,544$ & 0,1235 & \\
\hline part_timers & 0,169958 & 0,127461 & 1,333 & 0,1832 & \\
\hline part_timers_1 & $-0,197948$ & 0,115986 & $-1,707$ & 0,0887 & $*$ \\
\hline invol_part_timers & 0,098215 & 0,016491 & 5,956 & $6,12 \mathrm{E}-09$ & $* * *$ \\
\hline invol_part_timers_1 & $-0,0723589$ & 0,016044 & $-4,510$ & $8,76 \mathrm{E}-06$ & $* * *$ \\
\hline hours_worked & 0,377129 & 0,246259 & 1,531 & 0,1265 & \\
\hline hours_worked_1 & $-0,438222$ & 0,226561 & $-1,934$ & 0,0539 & $*$ \\
\hline temporary_emp & 0,067735 & 0,065701 & 1,031 & 0,3032 & \\
\hline temporary_emp_1 & $-0,0806417$ & 0,066762 & $-1,208$ & 0,2279 & \\
\hline EPL_regular & 0,22249 & 0,401422 & 0,5543 & 0,5797 & \\
\hline EPL_regular_1 & 0,299026 & 0,419583 & 0,7127 & 0,4765 & \\
\hline EPL_temporary & $-0,962564$ & 0,213792 & $-4,502$ & $9,07 \mathrm{E}-06$ & $* * *$ \\
\hline EPL_temporary_1 & 0,697189 & 0,222783 & 3,129 & 0,0019 & $* * *$ \\
\hline ALMP_expend & $-2,78554$ & 0,807096 & $-3,451$ & 0,0006 & $* * *$ \\
\hline ALMP_expend_1 & 1,16538 & 0,802904 & 1,451 & 0,1475 & \\
\hline PLMP_expend & 1,86965 & 0,362539 & 5,157 & $4,13 \mathrm{E}-07$ & $* * *$ \\
\hline PLMP_expend_1 & $-1,02421$ & 0,367543 & $-2,787$ & 0,0056 & $* * *$ \\
\hline GDP_per_cap & $-4,16230 \mathrm{e}-05$ & $6,74 \mathrm{E}-05$ & $-0,6177$ & 0,5371 & \\
\hline GDP_per_cap_1 & $4,27 \mathrm{E}-05$ & $6,61 \mathrm{E}-05$ & 0,6465 & 0,5184 & \\
\hline GDP_growth & $-0,0825735$ & 0,02697 & $-3,062$ & 0,0024 & $* * *$ \\
\hline GDP_growth_1 & 0,042638 & 0,028791 & 1,481 & 0,1395 & \\
\hline HICP & 0,049959 & 0,045757 & 1,092 & 0,2756 & \\
\hline HICP_1 & $-0,0287962$ & 0,043142 & $-0,6675$ & 0,5049 & \\
\hline NEET_rate_1 & 0,571445 & 0,04327 & 13,21 & $8,63 \mathrm{E}-33$ & $* * *$ \\
\hline Mean dependent var & 11,73871 & & S.D. dependent & var & 4,326133 \\
\hline Sum squared resid & 439,4787 & & S.E. of regressi & & 1,100311 \\
\hline LSDV R-squared & 0,943957 & & Within R-squar & & 0,760936 \\
\hline LSDV F(56, 363) & 109,1809 & & P-value(F) & & $1,00 \mathrm{E}-194$ \\
\hline Log-likelihood & $-605,4744$ & & Akaike criteriol & & 1324,949 \\
\hline Schwarz criterion & 1555,243 & & Hannan-Quinn & & 1415,972 \\
\hline rho & $-0,021634$ & & Durbin-Watson & & 1,895265 \\
\hline \multicolumn{6}{|c|}{$\begin{array}{l}\text { Joint test on named regressors - } \\
\text { Test statistic: } \mathrm{F}(29,363)=39,8422 \\
\text { with p-value }=\mathrm{P}(\mathrm{F}(29,363)>39,8422)=9,29654 \mathrm{e}-095\end{array}$} \\
\hline \multicolumn{6}{|c|}{$\begin{array}{l}\text { Test for differing group intercepts - } \\
\text { Null hypothesis: The groups have a common intercept } \\
\text { Test statistic: } \mathrm{F}(27,363)=3,58914 \\
\text { with p-value }=\mathrm{P}(\mathrm{F}(27,363)>3,58914)=1,65685 \mathrm{e}-008\end{array}$} \\
\hline
\end{tabular}

Megjegyzés: * jelöli a 10 százalékos, ** az 5 százalékos, *** pedig az 1 százalékos szinten szignifikáns hatással bíró változókat.

Forrás: saját szerkesztés. 
7. A 25-54 éves korosztály foglalkoztatási rátáját befolyásoló tényezők FE, 392 megfigyelés (28 ország, idősor hossza: 14 év)

Függő változó: felnőttek foglalkoztatási rátája

\begin{tabular}{|c|c|c|c|c|c|}
\hline & együttható & standard hiba & t-arány & p-érték & \\
\hline const & $-3,24025$ & 7,51008 & $-0,4315$ & 0,6664 & \\
\hline min_wage & 10,2923 & 3,27753 & 3,14 & 0,0018 & $* * *$ \\
\hline min_wage_1 & $-0,826875$ & 3,7739 & $-0,2191$ & 0,8267 & \\
\hline min_wage_2 & 1,7677 & 2,78783 & 0,6341 & 0,5265 & \\
\hline tax_wedge & 0,025305 & 0,034801 & 0,7271 & 0,4677 & \\
\hline tax_wedge_1 & $-0,0114862$ & 0,044475 & $-0,2583$ & 0,7964 & \\
\hline tax_wedge_2 & $-0,0128138$ & 0,03378 & $-0,3793$ & 0,7047 & \\
\hline trade_union_dens & 0,015178 & 0,009124 & 1,664 & 0,0972 & $*$ \\
\hline trade_union_dens_1 & $-0,00645588$ & 0,011136 & $-0,5797$ & 0,5625 & \\
\hline trade_union_dens_2 & $-0,00260981$ & 0,011079 & $-0,2356$ & 0,8139 & \\
\hline part_timers & 0,031494 & 0,104473 & 0,3015 & 0,7633 & \\
\hline part_timers_1 & 0,024047 & 0,124685 & 0,1929 & 0,8472 & \\
\hline part_timers_2 & 0,080145 & 0,093936 & 0,8532 & 0,3942 & \\
\hline invol_part_timers & $-0,0509705$ & 0,013199 & $-3,862$ & 0,0001 & $* * *$ \\
\hline invol_part_timers_1 & 0,014255 & 0,015845 & 0,8996 & 0,369 & \\
\hline invol_part_timers_2 & 0,008895 & 0,012992 & 0,6846 & 0,4941 & \\
\hline hours_worked & 0,195881 & 0,216858 & 0,9033 & 0,3671 & \\
\hline hours_worked_1 & 0,265506 & 0,244807 & 1,085 & 0,2789 & \\
\hline hours_worked_2 & $-0,0591187$ & 0,180263 & $-0,3280$ & 0,7432 & \\
\hline temporary_emp & 0,14447 & 0,057276 & 2,522 & 0,0121 & $* *$ \\
\hline temporary_emp_1 & $-0,0147601$ & 0,073346 & $-0,2012$ & 0,8406 & \\
\hline temporary_emp_2 & $-0,0316484$ & 0,055733 & $-0,5679$ & 0,5705 & \\
\hline EPL_regular & 1,95353 & 0,333133 & 5,864 & $1,13 \mathrm{E}-08$ & $* * *$ \\
\hline EPL_regular_1 & $-0,581626$ & 0,403129 & $-1,443$ & 0,1501 & \\
\hline EPL_regular_2 & 0,146243 & 0,372849 & 0,3922 & 0,6951 & \\
\hline EPL_temporary & 0,11494 & 0,170851 & 0,6727 & 0,5016 & \\
\hline EPL_temporary_1 & 0,066166 & 0,205417 & 0,3221 & 0,7476 & \\
\hline EPL_temporary_2 & 0,168391 & 0,176822 & 0,9523 & 0,3417 & \\
\hline ALMP_expend & $-0,137465$ & 0,674028 & $-0,2039$ & 0,8385 & \\
\hline ALMP_expend_1 & $-0,148014$ & 0,847011 & $-0,1747$ & 0,8614 & \\
\hline ALMP_expend_2 & $-0,275932$ & 0,672465 & $-0,4103$ & 0,6818 & \\
\hline PLMP_expend & $-1,53730$ & 0,298167 & $-5,156$ & $4,43 \mathrm{E}-07$ & $* * *$ \\
\hline PLMP_expend_1 & 0,75495 & 0,404815 & 1,865 & 0,0631 & $*$ \\
\hline PLMP_expend_2 & $-0,0941944$ & 0,322715 & $-0,2919$ & 0,7706 & \\
\hline GDP_per_cap & $-0,000148644$ & $5,64 \mathrm{E}-05$ & $-2,636$ & 0,0088 & $* * *$ \\
\hline GDP_per_cap_1 & 0,00012 & $8,30 \mathrm{E}-05$ & 1,446 & 0,1493 & \\
\hline GDP_per_cap_2 & $-3,09917 \mathrm{e}-05$ & $5,89 \mathrm{E}-05$ & $-0,5266$ & 0,5988 & \\
\hline GDP_growth & 0,155453 & 0,024686 & 6,297 & $9,99 \mathrm{E}-10$ & $* * *$ \\
\hline GDP_growth_1 & $-0,0537506$ & 0,036369 & $-1,478$ & 0,1404 & \\
\hline GDP_growth_2 & $-0,0453806$ & 0,024824 & $-1,828$ & 0,0685 & $*$ \\
\hline $\mathrm{HICP}$ & 0,049533 & 0,038436 & 1,289 & 0,1984 & \\
\hline HICP_1 & $-0,134646$ & 0,066351 & $-2,029$ & 0,0433 & $* *$ \\
\hline HICP_2 & 0,110487 & 0,044716 & 2,471 & 0,014 & $* *$ \\
\hline adult_emp_rate_1 & 0,834911 & 0,05331 & 15,66 & $1,95 \mathrm{E}-41$ & $* * *$ \\
\hline adult_emp_rate_2 & $-0,201355$ & 0,048876 & $-4,120$ & $4,84 \mathrm{E}-05$ & $* * *$ \\
\hline Mean dependent var & \multicolumn{2}{|l|}{78,01123} & \multicolumn{2}{|c|}{ S.D. dependent var } & 5,287638 \\
\hline Sum squared resid & \multicolumn{2}{|l|}{225,5138} & \multicolumn{2}{|c|}{ S.E. of regression } & 0,839482 \\
\hline LSDV R-squared & \multicolumn{2}{|l|}{0,979371} & \multicolumn{2}{|c|}{ Within R-squared } & 0,911554 \\
\hline LSDV F(71, 320) & \multicolumn{2}{|l|}{213,9765} & P-value(F) & & $2,30 \mathrm{E}-232$ \\
\hline
\end{tabular}


Joint test on named regressors -

Test statistic: $\mathrm{F}(44,320)=74,9552$

with $\mathrm{p}$-value $=\mathrm{P}(\mathrm{F}(44,320)>74,9552)=6,43054 \mathrm{e}-143$

Test for differing group intercepts -

Null hypothesis: The groups have a common intercept

Test statistic: $\mathrm{F}(27,320)=4,21315$

with p-value $=\mathrm{P}(\mathrm{F}(27,320)>4,21315)=1,75652 \mathrm{e}-010$

Megjegyzés: * jelöli a 10 százalékos, ** az 5 százalékos, *** pedig az 1 százalékos szinten szignifikáns hatással bíró változókat.

Forrás: saját szerkesztés.

8. A 25-54 éves korosztály munkanélküliségi rátáját befolyásoló tényezők

\begin{tabular}{|c|c|c|c|c|c|}
\hline \multicolumn{6}{|c|}{$\begin{array}{l}\text { FE, } 364 \text { megfigyelés ( } 28 \text { ország, idősor hossza: } 13 \text { év) } \\
\text { Függő változó: felnőttek munkanélküliségi rátája }\end{array}$} \\
\hline & együttható & standard hiba & t-arány & p-érték & \\
\hline const & $-3,42572$ & 8,57944 & $-0,3993$ & 0,69 & \\
\hline min_wage & 2,30558 & 3,04844 & 0,7563 & 0,4501 & \\
\hline min_wage_1 & $-0,857785$ & 3,71235 & $-0,2311$ & 0,8174 & \\
\hline min_wage_2 & $-0,809435$ & 3,54493 & $-0,2283$ & 0,8196 & \\
\hline min_wage_3 & 0,826652 & 2,70273 & 0,3059 & 0,7599 & \\
\hline tax_wedge & $-0,00458905$ & 0,031581 & $-0,1453$ & 0,8846 & \\
\hline tax_wedge_1 & $-0,00299031$ & 0,041775 & $-0,07158$ & 0,943 & \\
\hline tax_wedge_2 & 0,048028 & 0,041082 & 1,169 & 0,2434 & \\
\hline tax_wedge_3 & $-0,00781085$ & 0,031918 & $-0,2447$ & 0,8069 & \\
\hline trade_union_dens & $-0,00462628$ & 0,008696 & $-0,5320$ & 0,5952 & \\
\hline trade_union_dens_1 & 0,002953 & 0,010192 & 0,2897 & 0,7722 & \\
\hline trade_union_dens_2 & 0,002091 & 0,011563 & 0,1808 & 0,8567 & \\
\hline trade_union_dens_3 & $-0,00679542$ & 0,010551 & $-0,6440$ & 0,5201 & \\
\hline part_timers & 0,001194 & 0,100821 & 0,01184 & 0,9906 & \\
\hline part_timers_1 & $-0,0322526$ & 0,118515 & $-0,2721$ & 0,7857 & \\
\hline part_timers_2 & $-0,204126$ & 0,115361 & $-1,769$ & 0,0779 & $*$ \\
\hline part_timers_3 & 0,193491 & 0,086428 & 2,239 & 0,026 & $* *$ \\
\hline invol_part_timers & 0,02755 & 0,012547 & 2,196 & 0,0289 & $* *$ \\
\hline invol_part_timers_1 & $-0,00896956$ & 0,014735 & $-0,6087$ & 0,5432 & \\
\hline invol_part_timers_2 & $-0,0256496$ & 0,014318 & $-1,791$ & 0,0743 & $*$ \\
\hline invol_part_timers_3 & 0,026062 & 0,012147 & 2,146 & 0,0328 & $* *$ \\
\hline hours_worked & $-0,388382$ & 0,222762 & $-1,743$ & 0,0824 & $*$ \\
\hline hours_worked_1 & 0,159473 & 0,253251 & 0,6297 & 0,5294 & \\
\hline hours_worked_2 & 0,157723 & 0,220383 & 0,7157 & 0,4748 & \\
\hline hours_worked_3 & 0,172163 & 0,16606 & 1,037 & 0,3008 & \\
\hline temporary_emp & $-0,147025$ & 0,059231 & $-2,482$ & 0,0136 & $* *$ \\
\hline temporary_emp_1 & 0,084122 & 0,076819 & 1,095 & 0,2744 & \\
\hline temporary_emp_2 & 0,025672 & 0,07009 & 0,3663 & 0,7144 & \\
\hline temporary_emp_3 & 0,009602 & 0,05277 & 0,182 & 0,8557 & \\
\hline EPL_regular & $-0,493950$ & 0,318623 & $-1,550$ & 0,1222 & \\
\hline EPL_regular_1 & 0,361069 & 0,371156 & 0,9728 & 0,3315 & \\
\hline EPL_regular_2 & 0,96738 & 0,393603 & 2,458 & 0,0146 & $* *$ \\
\hline EPL_regular_3 & $-0,499469$ & 0,357859 & $-1,396$ & 0,1639 & \\
\hline EPL_temporary & $-0,0479523$ & 0,165002 & $-0,2906$ & 0,7716 & \\
\hline EPL_temporary_1 & $-0,354908$ & 0,188169 & $-1,886$ & 0,0603 & $*$ \\
\hline EPL_temporary_2 & $-0,0962916$ & 0,197137 & $-0,4884$ & 0,6256 & \\
\hline
\end{tabular}




\begin{tabular}{|c|c|c|c|c|c|}
\hline EPL_temporary_3 & 0,115455 & 0,175299 & 0,6586 & 0,5107 & \\
\hline ALMP_expend & $-0,983903$ & 0,647458 & $-1,520$ & 0,1297 & \\
\hline ALMP_expend_1 & 0,62088 & 0,796399 & 0,7796 & 0,4363 & \\
\hline ALMP_expend_2 & 0,132984 & 0,827295 & 0,1607 & 0,8724 & \\
\hline ALMP_expend_3 & $-0,234785$ & 0,624644 & $-0,3759$ & 0,7073 & \\
\hline PLMP_expend & 1,75951 & 0,282649 & 6,225 & $1,78 \mathrm{E}-09$ & *** \\
\hline PLMP_expend_1 & $-0,839662$ & 0,37888 & $-2,216$ & 0,0275 & $* *$ \\
\hline PLMP_expend_2 & 0,017749 & 0,391648 & 0,04532 & 0,9639 & \\
\hline PLMP_expend_3 & 0,307161 & 0,314899 & 0,9754 & 0,3302 & \\
\hline GDP_per_cap & 0,000108 & $5,20 \mathrm{E}-05$ & 2,084 & 0,0381 & $* *$ \\
\hline GDP_per_cap_1 & $-8,61996 \mathrm{e}-05$ & $7,64 \mathrm{E}-05$ & $-1,129$ & 0,2599 & \\
\hline GDP_per_cap_2 & $-5,49006 \mathrm{e}-05$ & $7,82 \mathrm{E}-05$ & $-0,7019$ & 0,4834 & \\
\hline GDP_per_cap_3 & 0,000111 & $5,51 \mathrm{E}-05$ & 2,006 & 0,0458 & $* *$ \\
\hline GDP_growth & $-0,139005$ & 0,023151 & $-6,004$ & $6,01 \mathrm{E}-09$ & $* * *$ \\
\hline GDP_growth_1 & 0,030011 & 0,036903 & 0,8133 & 0,4168 & \\
\hline GDP_growth_2 & 0,125975 & 0,036356 & 3,465 & 0,0006 & $* * *$ \\
\hline GDP_growth_3 & $-0,0603969$ & 0,024493 & $-2,466$ & 0,0143 & $* *$ \\
\hline HICP & $-0,0287360$ & 0,037181 & $-0,7729$ & 0,4403 & \\
\hline HICP_1 & 0,188866 & 0,063976 & 2,952 & 0,0034 & $* * *$ \\
\hline HICP_2 & $-0,240130$ & 0,07087 & $-3,388$ & 0,0008 & $* * *$ \\
\hline HICP_3 & 0,101686 & 0,044189 & 2,301 & 0,0221 & $* *$ \\
\hline adult_unemp_rate_1 & 1,05204 & 0,058774 & 17,9 & $3,84 \mathrm{E}-48$ & *** \\
\hline adult_unemp_rate_2 & $-0,214382$ & 0,07518 & $-2,852$ & 0,0047 & $* * *$ \\
\hline adult_unemp_rate_3 & $-0,110281$ & 0,051257 & $-2,152$ & 0,0323 & $* *$ \\
\hline Mean dependent var & \multicolumn{2}{|l|}{7,997886} & \multicolumn{2}{|c|}{ S.D. dependent var } & 4,103467 \\
\hline Sum squared resid & \multicolumn{2}{|l|}{150,0043} & \multicolumn{2}{|c|}{ S.E. of regression } & 0,735888 \\
\hline LSDV R-squared & \multicolumn{2}{|l|}{0,975459} & \multicolumn{2}{|c|}{ Within R-squared } & 0,949768 \\
\hline LSDV F(86, 277) & \multicolumn{2}{|l|}{128,0251} & \multicolumn{2}{|l|}{ P-value(F) } & $8,40 \mathrm{E}-183$ \\
\hline Log-likelihood & \multicolumn{2}{|l|}{$-355,1524$} & \multicolumn{2}{|l|}{ Akaike criterion } & 884,3048 \\
\hline Schwarz criterion & \multicolumn{2}{|l|}{1223,357} & \multicolumn{2}{|l|}{ Hannan-Quinn } & 1019,063 \\
\hline rho & \multicolumn{2}{|l|}{0,006589} & \multicolumn{2}{|l|}{ Durbin-Watson } & 1,847689 \\
\hline \multicolumn{6}{|c|}{$\begin{array}{l}\text { Joint test on named regressors - } \\
\text { Test statistic: } \mathrm{F}(59,277)=88,7695 \\
\text { with p-value }=\mathrm{P}(\mathrm{F}(59,277)>88,7695)=3,20146 \mathrm{e}-149\end{array}$} \\
\hline \multicolumn{6}{|c|}{$\begin{array}{l}\text { Test for differing group intercepts - } \\
\text { Null hypothesis: The groups have a common intercept } \\
\text { Test statistic: } \mathrm{F}(27,277)=2,10218 \\
\text { with p-value }=\mathrm{P}(\mathrm{F}(27,277)>2,10218)=0,00156154\end{array}$} \\
\hline
\end{tabular}

Megjegyzés: * jelöli a 10 százalékos, ** az 5 százalékos, *** pedig az 1 százalékos szinten szignifikáns hatással bíró változókat.

Forrás: saját szerkesztés.

9. Az 55-64 éves korosztály foglalkoztatási rátáját befolyásoló tényezők

\begin{tabular}{|c|c|c|c|c|c|}
\hline $\begin{array}{l}\text { FE, } 420 \text { megfigyelés } \\
\text { Függő változó: idős }\end{array}$ & $\begin{array}{l}\text { ország, idősor ho } \\
\text { k foglalkoztatás }\end{array}$ & $\begin{array}{l}\text { ssza: } 15 \text { év) } \\
\text { i rátája }\end{array}$ & & & \\
\hline & együttható & standard hiba & t-arány & p-érték & \\
\hline const & $-15,1327$ & 10,7845 & $-1,403$ & 0,1614 & \\
\hline min_wage & $-7,98886$ & 5,00631 & $-1,596$ & 0,1114 & \\
\hline min_wage_1 & 8,44869 & 4,66977 & 1,809 & 0,0712 & $*$ \\
\hline tax_wedge & $-0,149643$ & 0,057872 & $-2,586$ & 0,0101 & $* *$ \\
\hline tax_wedge_1 & 0,066698 & 0,057504 & 1,16 & 0,2469 & \\
\hline trade_union_dens & 0,013637 & 0,015566 & 0,8761 & 0,3816 & \\
\hline trade_union_dens_1 & 0,004027 & 0,017164 & 0,2346 & 0,8146 & \\
\hline
\end{tabular}




\begin{tabular}{|c|c|c|c|c|c|}
\hline part_timers & 0,301529 & 0,174377 & 1,729 & 0,0846 & $*$ \\
\hline part_timers_1 & $-0,0173780$ & 0,160052 & $-0,1086$ & 0,9136 & \\
\hline invol_part_timers & $-0,0413208$ & 0,022192 & $-1,862$ & 0,0634 & $*$ \\
\hline invol_part_timers_1 & 0,03491 & 0,021782 & 1,603 & 0,1099 & \\
\hline hours_worked & 0,127648 & 0,336476 & 0,3794 & 0,7046 & \\
\hline hours_worked_1 & 0,196834 & 0,310218 & 0,6345 & 0,5262 & \\
\hline temporary_emp & $-0,165705$ & 0,089987 & $-1,841$ & 0,0664 & $*$ \\
\hline temporary_emp_1 & 0,240755 & 0,091459 & 2,632 & 0,0088 & $* * *$ \\
\hline EPL_regular & 1,16906 & 0,54961 & 2,127 & 0,0341 & $* *$ \\
\hline EPL_regular_1 & $-0,266301$ & 0,577353 & $-0,4612$ & 0,6449 & \\
\hline EPL_temporary & 0,176283 & 0,292804 & 0,602 & 0,5475 & \\
\hline EPL_temporary_1 & $-0,362553$ & 0,300975 & $-1,205$ & 0,2291 & \\
\hline ALMP_expend & 1,33506 & 1,11636 & 1,196 & 0,2325 & \\
\hline ALMP_expend_1 & $-0,938590$ & 1,07998 & $-0,8691$ & 0,3854 & \\
\hline PLMP_expend & $-1,00208$ & 0,495753 & $-2,021$ & 0,044 & $* *$ \\
\hline PLMP_expend_1 & 0,063663 & 0,497538 & 0,128 & 0,8983 & \\
\hline GDP_per_cap & $-0,000156391$ & $9,20 \mathrm{E}-05$ & $-1,699$ & 0,0901 & $*$ \\
\hline GDP_per_cap_1 & 0,000128 & $9,05 \mathrm{E}-05$ & 1,41 & 0,1594 & \\
\hline GDP_growth & 0,172942 & 0,036728 & 4,709 & $3,55 \mathrm{E}-06$ & $* * *$ \\
\hline GDP_growth_1 & $-0,124528$ & 0,038762 & $-3,213$ & 0,0014 & $* * *$ \\
\hline HICP & $-0,00822796$ & 0,062556 & $-0,1315$ & 0,8954 & \\
\hline HICP_1 & 0,049444 & 0,059191 & 0,8353 & 0,4041 & \\
\hline old_emp_rate_1 & 0,839086 & 0,026783 & 31,33 & $3,00 \mathrm{E}-105$ & $* * *$ \\
\hline Mean dependent var & 44,66166 & & S.D. dependent & var & 11,22678 \\
\hline Sum squared resid & 824,4551 & & S.E. of regressi & & 1,507059 \\
\hline LSDV R-squared & 0,984389 & & Within R-squar & & 0,926452 \\
\hline LSDV F $(56,363)$ & 408,7359 & & P-value(F) & & $5,50 \mathrm{E}-295$ \\
\hline Log-likelihood & $-737,5924$ & & Akaike criterio & & 1589,185 \\
\hline Schwarz criterion & 1819,479 & & Hannan-Quinn & & 1680,208 \\
\hline rho & $-0,047987$ & & Durbin-Watson & & 1,907828 \\
\hline \multicolumn{6}{|c|}{$\begin{array}{l}\text { Joint test on named regressors - } \\
\text { Test statistic: } \mathrm{F}(29,363)=157,674 \\
\text { with p-value }=\mathrm{P}(\mathrm{F}(29,363)>157,674)=1,57466 \mathrm{e}-186\end{array}$} \\
\hline \multicolumn{6}{|c|}{$\begin{array}{l}\text { Test for differing group intercepts - } \\
\text { Null hypothesis: The groups have a common intercept } \\
\text { Test statistic: } \mathrm{F}(27,363)=2,71223 \\
\text { with p-value }=\mathrm{P}(\mathrm{F}(27,363)>2,71223)=1,57924 \mathrm{e}-005\end{array}$} \\
\hline
\end{tabular}

Megjegyzés: * jelöli a 10 százalékos, ** az 5 százalékos, *** pedig az 1 százalékos szinten szignifikáns hatással bíró változókat.

Forrás: saját szerkesztés.

10. Az 55-64 éves korosztály munkanélküliségi rátáját befolyásoló tényezők

\begin{tabular}{|c|c|c|c|c|c|}
\hline \multicolumn{6}{|c|}{$\begin{array}{l}\text { FE, } 392 \text { megfigyelés ( } 28 \text { ország, idősor hossza: } 14 \text { év) } \\
\text { Függő változó: idősebbek munkanélküliségi rátája }\end{array}$} \\
\hline & együttható & standard hiba & t-arány & p-érték & \\
\hline const & 0,635248 & 8,32042 & 0,07635 & 0,9392 & \\
\hline min_wage & $-0,229534$ & 3,38393 & $-0,06783$ & 0,946 & \\
\hline min_wage_1 & 1,76805 & 4,01386 & 0,4405 & 0,6599 & \\
\hline min_wage_2 & $-2,09071$ & 2,96825 & $-0,7044$ & 0,4817 & \\
\hline tax_wedge & 0,005442 & 0,036182 & 0,1504 & 0,8805 & \\
\hline tax_wedge_1 & $-0,0129850$ & 0,047253 & $-0,2748$ & 0,7837 & \\
\hline tax_wedge_2 & 0,044845 & 0,035994 & 1,246 & 0,2137 & \\
\hline trade_union_dens & $-0,0171360$ & 0,009678 & $-1,771$ & 0,0776 & * \\
\hline
\end{tabular}




\begin{tabular}{|c|c|c|c|c|c|}
\hline trade_union_dens_1 & 0,004227 & 0,011815 & 0,3578 & 0,7207 & \\
\hline trade_union_dens_2 & 0,001742 & 0,011754 & 0,1482 & 0,8823 & \\
\hline part_timers & 0,122436 & 0,111667 & 1,096 & 0,2737 & \\
\hline part_timers_1 & $-0,212619$ & 0,132557 & $-1,604$ & 0,1097 & \\
\hline part_timers_2 & 0,045282 & 0,101472 & 0,4463 & 0,6557 & \\
\hline invol_part_timers & 0,053748 & 0,013985 & 3,843 & 0,0001 & $* * *$ \\
\hline invol_part_timers_1 & $-0,0255218$ & 0,01697 & $-1,504$ & 0,1336 & \\
\hline invol_part_timers_2 & $-0,00359686$ & 0,013897 & $-0,2588$ & 0,7959 & \\
\hline hours_worked & $-0,250819$ & 0,22883 & $-1,096$ & 0,2739 & \\
\hline hours_worked_1 & $-0,128067$ & 0,260585 & $-0,4915$ & 0,6234 & \\
\hline hours_worked_2 & 0,404176 & 0,192083 & 2,104 & 0,0361 & $* *$ \\
\hline temporary_emp & 0,018184 & 0,060872 & 0,2987 & 0,7653 & \\
\hline temporary_emp_1 & $-0,0107648$ & 0,077777 & $-0,1384$ & 0,89 & \\
\hline temporary_emp_2 & $-0,0157169$ & 0,058138 & $-0,2703$ & 0,7871 & \\
\hline EPL_regular & $-1,63326$ & 0,349481 & $-4,673$ & $4,37 \mathrm{E}-06$ & $* * *$ \\
\hline EPL_regular_1 & 0,714853 & 0,425873 & 1,679 & 0,0942 & $*$ \\
\hline EPL_regular_2 & 0,374974 & 0,384788 & 0,9745 & 0,3305 & \\
\hline EPL_temporary & $-0,356113$ & 0,181319 & $-1,964$ & 0,0504 & $*$ \\
\hline EPL_temporary_1 & $-0,00214425$ & 0,21899 & $-0,009792$ & 0,9922 & \\
\hline EPL_temporary_2 & 0,125099 & 0,188111 & 0,665 & 0,5065 & \\
\hline ALMP_expend & $-1,55680$ & 0,71069 & $-2,191$ & 0,0292 & $* *$ \\
\hline ALMP_expend_1 & 1,04362 & 0,902034 & 1,157 & 0,2482 & \\
\hline ALMP_expend_2 & 0,199354 & 0,708934 & 0,2812 & 0,7787 & \\
\hline PLMP_expend & 0,65603 & 0,317317 & 2,067 & 0,0395 & $* *$ \\
\hline PLMP_expend_1 & 1,20608 & 0,414679 & 2,908 & 0,0039 & $* * *$ \\
\hline PLMP_expend_2 & $-0,877751$ & 0,351013 & $-2,501$ & 0,0129 & $* *$ \\
\hline GDP_per_cap & $5,26 \mathrm{E}-05$ & $5,98 \mathrm{E}-05$ & 0,8786 & 0,3803 & \\
\hline GDP_per_cap_1 & $-3,52385 \mathrm{e}-05$ & $8,80 \mathrm{E}-05$ & $-0,4003$ & 0,6892 & \\
\hline GDP_per_cap_2 & $1,86 \mathrm{E}-05$ & $6,27 \mathrm{E}-05$ & 0,2962 & 0,7673 & \\
\hline GDP_growth & $-0,0832335$ & 0,02618 & $-3,179$ & 0,0016 & $* * *$ \\
\hline GDP_growth_1 & $-0,0138421$ & 0,038177 & $-0,3626$ & 0,7172 & \\
\hline GDP_growth_2 & 0,072211 & 0,026236 & 2,752 & 0,0063 & $* * *$ \\
\hline HICP & 0,027217 & 0,040752 & 0,6679 & 0,5047 & \\
\hline HICP_1 & 0,122411 & 0,070405 & 1,739 & 0,0831 & $*$ \\
\hline HICP_2 & $-0,131956$ & 0,047504 & $-2,778$ & 0,0058 & $* * *$ \\
\hline old_unemp_rate_1 & 0,800301 & 0,050015 & 16 & $9,43 \mathrm{E}-43$ & $* * *$ \\
\hline old_unemp_rate_2 & $-0,0553654$ & 0,048161 & $-1,150$ & 0,2512 & \\
\hline Mean dependent var & 6,417625 & & S.D. dependent & var & 3,577141 \\
\hline Sum squared resid & 254,9729 & & S.E. of regressi & & 0,892631 \\
\hline LSDV R-squared & 0,949038 & & Within R-squar & & 0,901272 \\
\hline LSDV F(71, 320) & 83,9325 & & P-value(F) & & $5,40 \mathrm{E}-170$ \\
\hline Log-likelihood & $-471,9234$ & & Akaike criterior & & 1087,847 \\
\hline Schwarz criterion & 1373,778 & & Hannan-Quinn & & 1201,169 \\
\hline rho & $-0,018015$ & & Durbin-Watson & & 1,877189 \\
\hline $\begin{array}{l}\text { Joint test on named re } \\
\text { Test statistic: } F(44,3 \\
\text { with p-value }=\mathrm{P}(\mathrm{F}(4\end{array}$ & $\begin{array}{l}\text { sors - } \\
=66,3918 \\
20)>66,3918)\end{array}$ & $464 \mathrm{e}-135$ & & & \\
\hline \multicolumn{6}{|c|}{$\begin{array}{l}\text { Test for differing group intercepts - } \\
\text { Null hypothesis: The groups have a common intercept } \\
\text { Test statistic: } F(27,320)=1,78473 \\
\text { with p-value }=\mathrm{P}(\mathrm{F}(27,320)>1,78473)=0,0109362\end{array}$} \\
\hline
\end{tabular}

Megjegyzés: * jelöli a 10 százalékos, ** az 5 százalékos, *** pedig az 1 százalékos szinten szignifikáns hatással bíró változókat.

Forrás: saját szerkesztés. 
1. A teljes foglalkoztatási rátát befolyásoló tényezők

\begin{tabular}{|c|c|c|c|c|c|}
\hline \multicolumn{6}{|c|}{$\begin{array}{l}\text { FE, } 196 \text { megfigyelés ( } 28 \text { ország, idősor hossza: } 7 \text { év) } \\
\text { Függő változó: teljes foglalkoztatási ráta }\end{array}$} \\
\hline & együttható & standard hiba & t-arány & p-érték & \\
\hline const & 21,0171 & 8,44456 & 2,489 & 0,0139 & $* *$ \\
\hline min_wage & $-2,91212$ & 3,54814 & $-0,8207$ & 0,4131 & \\
\hline tax_wedge & $-0,0767989$ & 0,046766 & $-1,642$ & 0,1026 & \\
\hline trade_union_dens & 0,0187325 & 0,012366 & 1,515 & 0,1319 & \\
\hline part_timers & 0,20784 & 0,083465 & 2,49 & 0,0138 & $* *$ \\
\hline invol_part_timers & $-0,00745252$ & 0,0155631 & $-0,4789$ & 0,6327 & \\
\hline hours_worked & $-0,170433$ & 0,174479 & $-0,9768$ & 0,3302 & \\
\hline temporary_emp & 0,0459802 & 0,0430693 & 1,068 & 0,2874 & \\
\hline EPL_regular & 1,2176 & 0,44188 & 2,756 & 0,0066 & $* * *$ \\
\hline EPL_temporary & $-0,190209$ & 0,18414 & $-1,033$ & 0,3033 & \\
\hline ALMP_expend & 1,92416 & 0,711015 & 2,706 & 0,0076 & $* * *$ \\
\hline PLMP_expend & $-1,39758$ & 0,389516 & $-3,588$ & 0,0004 & $* * *$ \\
\hline GDP_per_cap & $-6,50976 \mathrm{e}-05$ & $3,77 \mathrm{E}-05$ & $-1,728$ & 0,086 & $*$ \\
\hline GDP_growth & 0,0948663 & 0,0218886 & 4,334 & $2,64 \mathrm{E}-05$ & $* * *$ \\
\hline HICP & $-0,0412435$ & 0,0301067 & $-1,370$ & 0,1727 & \\
\hline total_emp_rate_1 & 0,626136 & 0,047097 & 13,29 & $2,69 \mathrm{E}-27$ & $* * *$ \\
\hline \multirow{7}{*}{$\begin{array}{l}\text { Mean dependent var } \\
\text { Sum squared resid } \\
\text { LSDV R-squared } \\
\text { LSDV F(42, 153) } \\
\text { Log-likelihood } \\
\text { Schwarz criterion } \\
\text { rho }\end{array}$} & \multicolumn{2}{|l|}{53,47798} & \multicolumn{2}{|c|}{ S.D. dependent var } & 6,192429 \\
\hline & \multicolumn{2}{|l|}{85,61998} & \multicolumn{2}{|c|}{ S.E. of regression } & 0,748069 \\
\hline & \multicolumn{2}{|l|}{0,98855} & \multicolumn{2}{|c|}{ Within R-squared } & 0,789146 \\
\hline & \multicolumn{2}{|l|}{314,5011} & \multicolumn{2}{|l|}{ P-value(F) } & $6,10 \mathrm{E}-129$ \\
\hline & \multicolumn{2}{|l|}{$-196,9487$} & \multicolumn{2}{|c|}{ Akaike criterion } & 479,8975 \\
\hline & \multicolumn{2}{|l|}{620,8564} & & 536,9644 \\
\hline & $-0,216539$ & & \multicolumn{2}{|c|}{ Durbin-Watson } & 1,956036 \\
\hline \multicolumn{5}{|c|}{$\begin{array}{l}\text { Test statistic: } F(15,153)=38,1747 \\
\text { with p-value }=P(F(15,153)>38,1747)=5,39483 \mathrm{e}-044\end{array}$} & \\
\hline $\begin{array}{l}\text { Test for differing gro } \\
\text { Null hypothesis: Th } \\
\text { Test statistic: } \mathrm{F}(27, \\
\text { with p-value }=\mathrm{P}(\mathrm{F}(\end{array}$ & $\begin{array}{l}\text { tercepts - } \\
\text { ups have a com } \\
=5,50517 \\
53)>5,50517)\end{array}$ & $\begin{array}{l}\text { mon intercept } \\
=2,81877 \mathrm{e}-012\end{array}$ & \multicolumn{2}{|c|}{$\begin{array}{l}\text { Test statistic: } F(27,153)=5,50517 \\
\text { with p-value }=P(F(27,153)>5,50517)=2,81877 \mathrm{e}-012\end{array}$} & \\
\hline
\end{tabular}

Megjegyzés: * jelöli a 10 százalékos, ** az 5 százalékos, *** pedig az 1 százalékos szinten szignifikáns hatással bíró változókat.

Forrás: saját szerkesztés.

2. A teljes munkanélküliségi rátát befolyásoló tényezők

\begin{tabular}{|c|c|c|c|c|c|}
\hline $\begin{array}{l}\text { FE, } 196 \text { megfigyelés } \\
\text { Függő változó: telje }\end{array}$ & $\begin{array}{l}\text { ország, idősor ho } \\
\text { nkanélküliségi }\end{array}$ & $\begin{array}{l}\text { ssza: } 7 \text { év) } \\
\text { ráta }\end{array}$ & & & \\
\hline & együttható & standard hiba & t-arány & p-érték & \\
\hline const & 7,79904 & 10,9425 & 0,7127 & 0,4772 & \\
\hline min_wage & $-1,24724$ & 4,5499 & $-0,2741$ & 0,7844 & \\
\hline min_wage_1 & 6,22006 & 3,52333 & 1,765 & 0,0797 & * \\
\hline tax_wedge & $-0,0398893$ & 0,0617803 & $-0,6457$ & 0,5196 & \\
\hline tax_wedge_1 & 0,0695263 & 0,0625294 & 1,112 & 0,2681 & \\
\hline trade_union_dens & $-0,000336091$ & 0,0158698 & $-0,02118$ & 0,9831 & \\
\hline trade_union_dens_1 & 0,0017315 & 0,0178126 & 0,09721 & 0,9227 & \\
\hline
\end{tabular}




\begin{tabular}{|c|c|c|c|c|c|}
\hline part_timers & $-0,0429142$ & 0,145483 & $-0,2950$ & 0,7685 & \\
\hline part_timers_1 & 0,0011221 & 0,138994 & 0,008073 & 0,9936 & \\
\hline invol_part_timers & 0,0396595 & 0,0191016 & 2,076 & 0,0397 & $* *$ \\
\hline invol_part_timers_1 & $-0,0478949$ & 0,0198929 & $-2,408$ & 0,0174 & $* *$ \\
\hline hours_worked & $-0,103193$ & 0,236994 & $-0,4354$ & 0,6639 & \\
\hline hours_worked_1 & 0,0664485 & 0,224624 & 0,2958 & 0,7678 & \\
\hline temporary_emp & $-0,0672880$ & 0,0726998 & $-0,9256$ & 0,3563 & \\
\hline temporary_emp_1 & $-0,162489$ & 0,0811712 & $-2,002$ & 0,0473 & $* *$ \\
\hline EPL_regular & $-1,60757$ & 0,605213 & $-2,656$ & 0,0088 & $* * *$ \\
\hline EPL_regular_1 & 0,801535 & 0,65824 & 1,218 & 0,2254 & \\
\hline EPL_temporary & 0,565691 & 0,259451 & 2,18 & 0,0309 & $* *$ \\
\hline EPL_temporary_1 & $-0,161741$ & 0,259746 & $-0,6227$ & 0,5345 & \\
\hline ALMP_expend & $-1,56995$ & 1,09488 & $-1,434$ & 0,1538 & \\
\hline ALMP_expend_1 & $-0,584458$ & 1,08806 & $-0,5372$ & 0,592 & \\
\hline PLMP_expend & 1,98033 & 0,521771 & 3,795 & 0,0002 & $* * *$ \\
\hline PLMP_expend_1 & 0,0236149 & 0,574498 & 0,04111 & 0,9673 & \\
\hline GDP_per_cap & $1,36 \mathrm{E}-05$ & 0,000142 & 0,09605 & 0,9236 & \\
\hline GDP_per_cap_1 & 0,0001339 & 0,0001632 & 0,8208 & 0,4132 & \\
\hline GDP_growth & $-0,119239$ & 0,0625149 & $-1,907$ & 0,0585 & $*$ \\
\hline GDP_growth_1 & 0,0297812 & 0,0667951 & 0,4459 & 0,6564 & \\
\hline $\mathrm{HICP}$ & 0,0399769 & 0,0969198 & 0,4125 & 0,6806 & \\
\hline HICP_1 & $-0,0118666$ & 0,0816042 & $-0,1454$ & 0,8846 & \\
\hline total_unemp_rate_1 & 0,653388 & 0,0645309 & 10,13 & $2,17 \mathrm{E}-18$ & $* * *$ \\
\hline Mean dependent var & 8,133959 & & S.D. depende & var & 3,824246 \\
\hline Sum squared resid & 94,91518 & & S.E. of regres & & 0,826343 \\
\hline LSDV R-squared & 0,966718 & & Within R-squ & & 0,851844 \\
\hline LSDV F(56, 139) & 72,09699 & & P-value $(F)$ & & $5,01 \mathrm{E}-80$ \\
\hline Log-likelihood & $-207,0491$ & & Akaike criter & & 528,0982 \\
\hline Schwarz criterion & 714,9508 & & Hannan-Quin & & 603,7451 \\
\hline rho & $-0,120458$ & & Durbin-Wats & & 1,858292 \\
\hline \multicolumn{6}{|c|}{$\begin{array}{l}\text { Joint test on named regressors - } \\
\text { Test statistic: } \mathrm{F}(29,139)=27,5586 \\
\text { with p-value }=\mathrm{P}(\mathrm{F}(29,139)>27,5586)=3,28895 \mathrm{e}-044\end{array}$} \\
\hline \multicolumn{6}{|c|}{$\begin{array}{l}\text { Test for differing group intercepts - } \\
\text { Null hypothesis: The groups have a common intercept } \\
\text { Test statistic: } \mathrm{F}(27,139)=2,67486 \\
\text { with p-value }=\mathrm{P}(\mathrm{F}(27,139)>2,67486)=0,000101177\end{array}$} \\
\hline
\end{tabular}

Megjegyzés: * jelöli a 10 százalékos, ** az 5 százalékos, *** pedig az 1 százalékos szinten szignifikáns hatással bíró változókat.

Forrás: saját szerkesztés.

3. Az ifjúsági foglalkoztatási rátát befolyásoló tényezők

\begin{tabular}{|c|c|c|c|c|c|}
\hline \multicolumn{6}{|c|}{$\begin{array}{l}\text { FE, } 196 \text { megfigyelés ( } 28 \text { ország, idősor hossza: } \\
\text { Függő változó: ifjúsági foglalkoztatási ráta }\end{array}$} \\
\hline & együttható & standard hiba & t-arány & p-érték & \\
\hline const & 9,49233 & 16,2215 & 0,5852 & 0,5594 & \\
\hline min_wage & 2,35966 & 7,02548 & 0,3359 & 0,7375 & \\
\hline min_wage_1 & $-11,7098$ & 5,46265 & $-2,144$ & 0,0338 & $* *$ \\
\hline tax_wedge & $-0,0426648$ & 0,0957878 & $-0,4454$ & 0,6567 & \\
\hline tax_wedge_1 & 0,0660254 & 0,096897 & 0,6814 & 0,4968 & \\
\hline trade_union_dens & $-0,0297713$ & 0,0246586 & $-1,207$ & 0,2294 & \\
\hline trade_union_dens_1 & 0,0061474 & 0,0277012 & 0,2219 & 0,8247 & \\
\hline part_timers & 0,745822 & 0,225457 & 3,308 & 0,0012 & $* * *$ \\
\hline
\end{tabular}




\begin{tabular}{|c|c|c|c|c|c|}
\hline part_timers_1 & $-0,329933$ & 0,216536 & $-1,524$ & 0,1299 & \\
\hline invol_part_timers & $-0,0192431$ & 0,029957 & $-0,6424$ & 0,5217 & \\
\hline invol_part_timers_1 & 0,0403463 & 0,0306681 & 1,316 & 0,1905 & \\
\hline hours_worked & $-0,452586$ & 0,361138 & $-1,253$ & 0,2122 & \\
\hline hours_worked_1 & 0,346253 & 0,352699 & 0,9817 & 0,3279 & \\
\hline temporary_emp & 0,334142 & 0,113502 & 2,944 & 0,0038 & $* * *$ \\
\hline temporary_emp_1 & $-0,307130$ & 0,12789 & $-2,402$ & 0,0176 & $* *$ \\
\hline EPL_regular & 0,145527 & 0,94542 & 0,1539 & 0,8779 & \\
\hline EPL_regular_1 & $-0,450720$ & 1,0113 & $-0,4457$ & 0,6565 & \\
\hline EPL_temporary & $-0,793111$ & 0,40292 & $-1,968$ & 0,051 & $*$ \\
\hline EPL_temporary_1 & 1,26052 & 0,402178 & 3,134 & 0,0021 & $* * *$ \\
\hline ALMP_expend & 0,770913 & 1,68345 & 0,4579 & 0,6477 & \\
\hline ALMP_expend_1 & 2,10918 & 1,66546 & 1,266 & 0,2075 & \\
\hline PLMP_expend & $-2,99743$ & 0,809531 & $-3,703$ & 0,0003 & $* * *$ \\
\hline PLMP_expend_1 & 1,28602 & 0,816547 & 1,575 & 0,1175 & \\
\hline GDP_per_cap & $-0,000217631$ & 0,0002203 & $-0,9881$ & 0,3248 & \\
\hline GDP_per_cap_1 & $-7,46913 e-05$ & 0,000254 & $-0,2941$ & 0,7692 & \\
\hline GDP_growth & 0,265077 & 0,0950054 & 2,79 & 0,006 & $* * *$ \\
\hline GDP_growth_1 & $-0,113703$ & 0,103463 & $-1,099$ & 0,2737 & \\
\hline $\mathrm{HICP}$ & 0,101903 & 0,150693 & 0,6762 & 0,5 & \\
\hline HICP_1 & $-0,195492$ & 0,128926 & $-1,516$ & 0,1317 & \\
\hline youth_emp_rate_1 & 0,756242 & 0,0533879 & 14,17 & $9,44 \mathrm{E}-29$ & $* * *$ \\
\hline Mean dependent var & 36,32088 & & S.D. depende & var & 12,60172 \\
\hline Sum squared resid & 228,4747 & & S.E. of regres & & 1,28207 \\
\hline LSDV R-squared & 0,992622 & & Within R-squ & & 0,765048 \\
\hline LSDV F(56, 139) & 333,939 & & P-value $(F)$ & & $3,40 \mathrm{E}-125$ \\
\hline Log-likelihood & $-293,1364$ & & Akaike criteri & & 700,2728 \\
\hline Schwarz criterion & 887,1253 & & Hannan-Quin & & 775,9196 \\
\hline rho & $-0,147896$ & & Durbin-Wats & & 1,89851 \\
\hline \multicolumn{6}{|c|}{$\begin{array}{l}\text { Joint test on named regressors - } \\
\text { Test statistic: } \mathrm{F}(29,139)=15,6073 \\
\text { with p-value }=\mathrm{P}(\mathrm{F}(29,139)>15,6073)=6,55477 \mathrm{e}-031\end{array}$} \\
\hline \multicolumn{6}{|c|}{$\begin{array}{l}\text { Test for differing group intercepts - } \\
\text { Null hypothesis: The groups have a common intercept } \\
\text { Test statistic: } \mathrm{F}(27,139)=2,75789 \\
\text { with p-value }=\mathrm{P}(\mathrm{F}(27,139)>2,75789)=6,15305 \mathrm{e}-005\end{array}$} \\
\hline
\end{tabular}

Megjegyzés: * jelöli a 10 százalékos, ** az 5 százalékos, *** pedig az 1 százalékos szinten szignifikáns hatással bíró változókat.

Forrás: saját szerkesztés.

4. Az ifjúsági munkanélküliségi rátát befolyásoló tényezők

\begin{tabular}{|c|c|c|c|c|c|}
\hline \multicolumn{6}{|c|}{$\begin{array}{l}\text { FE, } 196 \text { megfigyelés ( } 28 \text { ország, idősor hossza: } 7 \text { év } \\
\text { Függő változó: ifjúsági munkanélküliségi ráta }\end{array}$} \\
\hline & együttható & standard hiba & t-arány & p-érték & \\
\hline const & 6,37265 & 24,162 & 0,2637 & 0,7923 & \\
\hline min_wage & 11,4792 & 10,2379 & 1,121 & 0,2639 & \\
\hline tax_wedge & $-0,0374955$ & 0,135021 & $-0,2777$ & 0,7816 & \\
\hline trade_union_dens & 0,068006 & 0,0356236 & 1,909 & 0,0581 & $*$ \\
\hline part_timers & 0,0132336 & 0,236136 & 0,05604 & 0,9554 & \\
\hline invol_part_timers & 0,088965 & 0,0459441 & 1,936 & 0,0547 & $*$ \\
\hline hours_worked & 0,23515 & 0,509786 & 0,4613 & 0,6453 & \\
\hline temporary_emp & $-0,392875$ & 0,122257 & $-3,214$ & 0,0016 & $* * *$ \\
\hline EPL_regular & $-1,83014$ & 1,27803 & $-1,432$ & 0,1542 & \\
\hline
\end{tabular}




\begin{tabular}{|c|c|c|c|c|c|}
\hline EPL_temporary & 1,15868 & 0,547839 & 2,115 & 0,0361 & $* *$ \\
\hline ALMP_expend & $-5,89303$ & 2,06223 & $-2,858$ & 0,0049 & $* * *$ \\
\hline PLMP_expend & 3,75214 & 1,13994 & 3,292 & 0,0012 & $* * *$ \\
\hline GDP_per_cap & 0,0003291 & 0,0001155 & 2,85 & 0,005 & $* * *$ \\
\hline GDP_growth & $-0,181074$ & 0,0624285 & $-2,900$ & 0,0043 & $* * *$ \\
\hline HICP & $-0,00693294$ & 0,084273 & $-0,08227$ & 0,9345 & \\
\hline youth_unemp_rate_1 & 0,647315 & 0,0595514 & 10,87 & $9,41 \mathrm{E}-21$ & $* * *$ \\
\hline Mean dependent var & 17,92485 & & S.D. depende & var & 8,16155 \\
\hline Sum squared resid & 719,0245 & & S.E. of regres & & 2,167835 \\
\hline LSDV R-squared & 0,944644 & & Within R-squ & & 0,737282 \\
\hline LSDV F(42, 153) & 62,16509 & & P-value(F) & & $5,61 \mathrm{E}-77$ \\
\hline Log-likelihood & $-405,4905$ & & Akaike criter & & 896,9809 \\
\hline Schwarz criterion & 1037,94 & & Hannan-Quin & & 954,0479 \\
\hline rho & $-0,141191$ & & Durbin-Wats & & 1,941624 \\
\hline \multicolumn{6}{|c|}{$\begin{array}{l}\text { Joint test on named regressors - } \\
\text { Test statistic: } \mathrm{F}(15,153)=28,6249 \\
\text { with p-value }=\mathrm{P}(\mathrm{F}(15,153)>28,6249)=7,07467 \mathrm{e}-037\end{array}$} \\
\hline \multicolumn{6}{|c|}{$\begin{array}{l}\text { Test for differing group intercepts - } \\
\text { Null hypothesis: The groups have a common intercept } \\
\text { Test statistic: } \mathrm{F}(27,153)=3,13119 \\
\text { with p-value }=\mathrm{P}(\mathrm{F}(27,153)>3,13119)=4,86203 \mathrm{e}-006\end{array}$} \\
\hline
\end{tabular}

Megjegyzés: * jelöli a 10 százalékos, ** az 5 százalékos, *** pedig az 1 százalékos szinten szignifikáns hatással bíró változókat.

Forrás: saját szerkesztés.

5. Az ifjúsági munkanélküliségi arányt befolyásoló tényezők

\begin{tabular}{|c|c|c|c|c|c|}
\hline \multicolumn{6}{|c|}{$\begin{array}{l}\text { FE, } 196 \text { megfigyelés ( } 28 \text { ország, idősor hossza: } 7 \text { év) } \\
\text { Függő változó: ifjúsági munkanélküliségi arány }\end{array}$} \\
\hline & együttható & standard hiba & t-arány & p-érték & \\
\hline const & $-6,80181$ & 10,345 & $-0,6575$ & 0,5119 & \\
\hline min_wage & 5,78418 & 4,42676 & 1,307 & 0,1933 & \\
\hline tax_wedge & 0,0342937 & 0,0589853 & 0,5814 & 0,5618 & \\
\hline trade_union_dens & 0,0385647 & 0,015549 & 2,48 & 0,0142 & $* *$ \\
\hline part_timers & 0,0957065 & 0,102873 & 0,9303 & 0,3537 & \\
\hline invol_part_timers & 0,0356765 & 0,0197741 & 1,804 & 0,0732 & $*$ \\
\hline hours_worked & 0,239281 & 0,219182 & 1,092 & 0,2767 & \\
\hline temporary_emp & $-0,120307$ & 0,0529058 & $-2,274$ & 0,0244 & $* *$ \\
\hline EPL_regular & $-0,248214$ & 0,553758 & $-0,4482$ & 0,6546 & \\
\hline EPL_temporary & 0,411073 & 0,237838 & 1,728 & 0,0859 & $*$ \\
\hline ALMP_expend & $-2,98946$ & 0,903877 & $-3,307$ & 0,0012 & $* * *$ \\
\hline PLMP_expend & 1,90791 & 0,49212 & 3,877 & 0,0002 & $* * *$ \\
\hline GDP_per_cap & 0,0001269 & $5,01 \mathrm{E}-05$ & 2,532 & 0,0123 & $* *$ \\
\hline GDP_growth & $-0,0487585$ & 0,0268912 & $-1,813$ & 0,0718 & $*$ \\
\hline HICP & $-0,0381523$ & 0,0365343 & $-1,044$ & 0,298 & \\
\hline youth_unemp_ratio_1 & 0,52212 & 0,0608411 & 8,582 & $9,82 \mathrm{E}-15$ & $* * *$ \\
\hline Mean dependent var & 7,335717 & & S.D. depende & nt var & 2,886909 \\
\hline Sum squared resid & 135,2917 & & S.E. of regres & sion & 0,940351 \\
\hline LSDV R-squared & 0,916753 & & Within R-squ & ared & 0,706799 \\
\hline LSDV F(42, 153) & 40,1166 & & P-value(F) & & $1,12 \mathrm{E}-63$ \\
\hline Log-likelihood & $-241,7851$ & & Akaike criter & ion & 569,5703 \\
\hline Schwarz criterion & 710,5292 & & Hannan-Quin & & 626,6372 \\
\hline rho & $-0,122635$ & & Durbin-Wats & & 1,847749 \\
\hline
\end{tabular}


Joint test on named regressors -

Test statistic: $\mathrm{F}(15,153)=24,5884$

with $\mathrm{p}$-value $=\mathrm{P}(\mathrm{F}(15,153)>24,5884)=2,39831 \mathrm{e}-033$

Test for differing group intercepts -

Null hypothesis: The groups have a common intercept

Test statistic: $F(27,153)=3,29017$

with p-value $=\mathrm{P}(\mathrm{F}(27,153)>3,29017)=1,80149 \mathrm{e}-006$

Megjegyzés: * jelöli a 10 százalékos, ** az 5 százalékos, *** pedig az 1 százalékos szinten szignifikáns hatással bíró változókat.

Forrás: saját szerkesztés.

\section{A NEET rátát befolyásoló tényezők}

\begin{tabular}{|c|c|c|c|c|c|}
\hline \multicolumn{6}{|c|}{$\begin{array}{l}\text { FE, } 168 \text { megfigyelés ( } 28 \text { ország, idősor hossza: } 6 \text { év) } \\
\text { Függő változó: NEET ráta }\end{array}$} \\
\hline & együttható & standard hiba & t-arány & p-érték & \\
\hline const & $-23,4337$ & 21,7506 & $-1,077$ & 0,284 & \\
\hline min_wage & 53,318 & 8,49257 & 6,278 & $9,92 \mathrm{E}-09$ & $* * *$ \\
\hline min_wage_1 & $-24,1031$ & 10,121 & $-2,381$ & 0,0192 & $* *$ \\
\hline min_wage_2 & 14,0955 & 7,22235 & 1,952 & 0,0539 & $*$ \\
\hline tax_wedge & $-0,0420991$ & 0,106331 & $-0,3959$ & 0,693 & \\
\hline tax_wedge_1 & 0,226813 & 0,111385 & 2,036 & 0,0445 & $* *$ \\
\hline tax_wedge_2 & $-0,0719164$ & 0,119476 & $-0,6019$ & 0,5486 & \\
\hline trade_union_dens & 0,0586205 & 0,0286988 & 2,043 & 0,0438 & $* *$ \\
\hline trade_union_dens_1 & $-0,0366418$ & 0,0346306 & $-1,058$ & 0,2927 & \\
\hline trade_union_dens_2 & 0,0140799 & 0,0357628 & 0,3937 & 0,6947 & \\
\hline part_timers & 0,240761 & 0,261608 & 0,9203 & 0,3597 & \\
\hline part_timers_1 & $-0,0916058$ & 0,275975 & $-0,3319$ & 0,7407 & \\
\hline part_timers_2 & $-0,156802$ & 0,255025 & $-0,6148$ & 0,5401 & \\
\hline invol_part_timers & 0,0955151 & 0,0333937 & 2,86 & 0,0052 & $* * *$ \\
\hline invol_part_timers_1 & $-0,0216774$ & 0,0353377 & $-0,6134$ & 0,541 & \\
\hline invol_part_timers_2 & $-0,0196179$ & 0,0470985 & $-0,4165$ & 0,678 & \\
\hline hours_worked & 0,855764 & 0,432108 & 1,98 & 0,0505 & $*$ \\
\hline hours_worked_1 & $-0,437747$ & 0,419703 & $-1,043$ & 0,2996 & \\
\hline hours_worked_2 & 0,0077258 & 0,365524 & 0,02114 & 0,9832 & \\
\hline temporary_emp & 0,155375 & 0,147148 & 1,056 & 0,2937 & \\
\hline temporary_emp_1 & $-0,302934$ & 0,174565 & $-1,735$ & 0,0859 & $*$ \\
\hline temporary_emp_2 & 0,0850764 & 0,150543 & 0,5651 & 0,5733 & \\
\hline EPL_regular & 0,916419 & 1,10176 & 0,8318 & 0,4076 & \\
\hline EPL_regular_1 & $-1,25114$ & 1,34502 & $-0,9302$ & 0,3546 & \\
\hline EPL_regular_2 & 0,963045 & 1,24726 & 0,7721 & 0,4419 & \\
\hline EPL_temporary & $-1,88153$ & 0,43938 & $-4,282$ & $4,39 \mathrm{E}-05$ & $* * *$ \\
\hline EPL_temporary_1 & 0,294845 & 0,473492 & 0,6227 & 0,535 & \\
\hline EPL_temporary_2 & 0,604158 & 0,476093 & 1,269 & 0,2075 & \\
\hline ALMP_expend & $-6,46392$ & 1,8863 & $-3,427$ & 0,0009 & $* * *$ \\
\hline ALMP_expend_1 & 3,05087 & 2,28001 & 1,338 & 0,184 & \\
\hline ALMP_expend_2 & $-1,00792$ & 1,93647 & $-0,5205$ & 0,6039 & \\
\hline PLMP_expend & 0,466969 & 0,957093 & 0,4879 & 0,6267 & \\
\hline PLMP_expend_1 & 0,297128 & 1,06462 & 0,2791 & 0,7808 & \\
\hline PLMP_expend_2 & 0,186085 & 0,978637 & 0,1901 & 0,8496 & \\
\hline GDP_per_cap & $-0,000478767$ & 0,0002642 & $-1,812$ & 0,0731 & $*$ \\
\hline GDP_per_cap_1 & 0,0005965 & 0,0003599 & 1,657 & 0,1008 & \\
\hline GDP_per_cap_2 & $-0,000118811$ & 0,0002952 & $-0,4025$ & 0,6882 & \\
\hline GDP_growth & 0,119941 & 0,118655 & 1,011 & 0,3146 & \\
\hline GDP_growth_1 & $-0,185178$ & 0,153279 & $-1,208$ & 0,23 & \\
\hline
\end{tabular}




\begin{tabular}{|c|c|c|c|c|c|}
\hline GDP_growth_2 & $-0,0365160$ & 0,121205 & $-0,3013$ & 0,7639 & \\
\hline HICP & 0,27304 & 0,175722 & 1,554 & 0,1235 & \\
\hline HICP_1 & $-0,338191$ & 0,252664 & $-1,338$ & 0,1839 & \\
\hline HICP_2 & 0,125273 & 0,156807 & 0,7989 & 0,4263 & \\
\hline NEET_rate_1 & 0,214047 & 0,107904 & 1,984 & 0,0501 & $*$ \\
\hline NEET_rate_2 & $-0,145052$ & 0,125521 & $-1,156$ & 0,2507 & \\
\hline Mean dependent var & 11,44777 & & S.D. depen & & 4,142652 \\
\hline Sum squared resid & 134,3723 & & S.E. of regr & & 1,183094 \\
\hline LSDV R-squared & 0,953115 & & Within R-sc & & 0,737903 \\
\hline LSDV F(71, 96) & 27,48665 & & P-value $(F)$ & & $6,41 \mathrm{E}-42$ \\
\hline Log-likelihood & $-219,6203$ & & Akaike crit & & 583,2406 \\
\hline Schwarz criterion & 808,166 & & Hannan-Qu & & 674,5262 \\
\hline rho & $-0,120982$ & & Durbin-Wa & & 1,905506 \\
\hline \multicolumn{6}{|c|}{$\begin{array}{l}\text { Joint test on named regressors - } \\
\text { Test statistic: } F(44,96)=6,14264 \\
\text { with p-value }=P(F(44,96)>6,14264)=6,54727 \mathrm{e}-014\end{array}$} \\
\hline \multicolumn{6}{|c|}{$\begin{array}{l}\text { Test for differing group intercepts - } \\
\text { Null hypothesis: The groups have a common intercept } \\
\text { Test statistic: } F(27,96)=1,64629 \\
\text { with p-value }=\mathrm{P}(\mathrm{F}(27,96)>1,64629)=0,0409342\end{array}$} \\
\hline
\end{tabular}

Megjegyzés: * jelöli a 10 százalékos, ** az 5 százalékos, *** pedig az 1 százalékos szinten szignifikáns hatással bíró változókat.

Forrás: saját szerkesztés.

7. A 25-54 éves korosztály foglalkoztatási rátáját befolyásoló tényezők

\begin{tabular}{|c|c|c|c|c|c|}
\hline \multicolumn{6}{|c|}{$\begin{array}{l}\text { FE, } 196 \text { megfigyelés ( } 28 \text { ország, idősor hossza: } 7 \text { é } \\
\text { Függő változó: felnőttek foglalkoztatási rátája }\end{array}$} \\
\hline & együttható & standard hiba & t-arány & p-érték & \\
\hline const & 19,263 & 9,18295 & 2,098 & 0,0376 & $* *$ \\
\hline min_wage & $-2,50236$ & 3,79738 & $-0,6590$ & 0,5109 & \\
\hline tax_wedge & $-0,0623933$ & 0,0499669 & $-1,249$ & 0,2137 & \\
\hline trade_union_dens & 0,0372425 & 0,0132103 & 2,819 & 0,0055 & $* * *$ \\
\hline part_timers & 0,0982672 & 0,0876727 & 1,121 & 0,2641 & \\
\hline invol_part_timers & 0,0058147 & 0,0166943 & 0,3483 & 0,7281 & \\
\hline hours_worked & $-0,0698423$ & 0,187849 & $-0,3718$ & 0,7106 & \\
\hline temporary_emp & 0,0935516 & 0,0453274 & 2,064 & 0,0407 & $* *$ \\
\hline EPL_regular & 2,07618 & 0,474736 & 4,373 & $2,25 \mathrm{E}-05$ & $* * *$ \\
\hline EPL_temporary & 0,0723169 & 0,1979 & 0,3654 & 0,7153 & \\
\hline ALMP_expend & 0,860885 & 0,763646 & 1,127 & 0,2614 & \\
\hline PLMP_expend & $-1,81756$ & 0,418665 & $-4,341$ & $2,56 \mathrm{E}-05$ & $* * *$ \\
\hline GDP_per_cap & $-3,72459 \mathrm{e}-05$ & $4,06 \mathrm{E}-05$ & $-0,9184$ & 0,3598 & \\
\hline GDP_growth & 0,0655349 & 0,023324 & 2,81 & 0,0056 & $* * *$ \\
\hline HICP & 0,0190139 & 0,0313774 & 0,606 & 0,5454 & \\
\hline adult_emp_rate_1 & 0,647693 & 0,0513663 & 12,61 & $1,90 \mathrm{E}-25$ & $* * *$ \\
\hline Mean dependent var & 77,62891 & & S.D. depen & lent var & 5,376282 \\
\hline Sum squared resid & 98,5183 & & S.E. of regr & ession & 0,80244 \\
\hline LSDV R-squared & 0,982521 & & Within R-sc & quared & 0,83167 \\
\hline LSDV F(42, 153) & 204,7697 & & P-value(F) & & $6,10 \mathrm{E}-115$ \\
\hline Log-likelihood & $-210,7005$ & & Akaike crit & erion & 507,4009 \\
\hline Schwarz criterion & 648,3599 & & Hannan-Qu & inn & 564,4679 \\
\hline rho & $-0,185302$ & & Durbin-Wa & son & 1,947605 \\
\hline
\end{tabular}


Joint test on named regressors -

Test statistic: $F(15,153)=50,3954$

with $\mathrm{p}$-value $=\mathrm{P}(\mathrm{F}(15,153)>50,3954)=2,47951 \mathrm{e}-051$

Test for differing group intercepts -

Null hypothesis: The groups have a common intercept

Test statistic: $\mathrm{F}(27,153)=4,4356$

with p-value $=\mathrm{P}(\mathrm{F}(27,153)>4,4356)=1,53987 \mathrm{e}-009$

Megjegyzés: * jelöli a 10 százalékos, ** az 5 százalékos, *** pedig az 1 százalékos szinten szignifikáns hatással bíró változókat.

Forrás: saját szerkesztés.

8. A 25-54 éves korosztály munkanélküliségi rátáját befolyásoló tényezők

\begin{tabular}{|c|c|c|c|c|c|}
\hline \multicolumn{6}{|c|}{$\begin{array}{l}\text { FE, } 196 \text { megfigyelés ( } 28 \text { ország, idősor hossza: } 7 \text { év) } \\
\text { Függő változó: felnőttek munkanélküliségi rátája }\end{array}$} \\
\hline & együttható & standard hiba & t-arány & p-érték & \\
\hline const & 11,7799 & 9,89288 & 1,191 & 0,2358 & \\
\hline min_wage & $-1,87987$ & 4,04617 & $-0,4646$ & 0,6429 & \\
\hline min_wage_1 & 5,8299 & 3,13204 & 1,861 & 0,0648 & $*$ \\
\hline tax_wedge & $-0,0389548$ & 0,0549974 & $-0,7083$ & 0,4799 & \\
\hline tax_wedge_1 & 0,0679616 & 0,0555723 & 1,223 & 0,2234 & \\
\hline trade_union_dens & $-0,00945206$ & 0,0141072 & $-0,6700$ & 0,504 & \\
\hline trade_union_dens_1 & 0,0038868 & 0,0158511 & 0,2452 & 0,8067 & \\
\hline part_timers & $-0,0534243$ & 0,129392 & $-0,4129$ & 0,6803 & \\
\hline part_timers_1 & 0,0237555 & 0,123597 & 0,1922 & 0,8479 & \\
\hline invol_part_timers & 0,022554 & 0,0170278 & 1,325 & 0,1875 & \\
\hline invol_part_timers_1 & $-0,0381740$ & 0,0176311 & $-2,165$ & 0,0321 & $* *$ \\
\hline hours_worked & $-0,0844807$ & 0,211712 & $-0,3990$ & 0,6905 & \\
\hline hours_worked_1 & $-0,0638566$ & 0,199931 & $-0,3194$ & 0,7499 & \\
\hline temporary_emp & $-0,0629461$ & 0,0651296 & $-0,9665$ & 0,3355 & \\
\hline temporary_emp_1 & $-0,137371$ & 0,0722729 & $-1,901$ & 0,0594 & $*$ \\
\hline EPL_regular & $-1,39392$ & 0,539333 & $-2,585$ & 0,0108 & $* *$ \\
\hline EPL_regular_1 & 0,527518 & 0,583313 & 0,9043 & 0,3674 & \\
\hline EPL_temporary & 0,466026 & 0,229799 & 2,028 & 0,0445 & $* *$ \\
\hline EPL_temporary_1 & $-0,0688922$ & 0,230709 & $-0,2986$ & 0,7657 & \\
\hline ALMP_expend & $-0,805770$ & 0,972487 & $-0,8286$ & 0,4088 & \\
\hline ALMP_expend_1 & $-1,06713$ & 0,962146 & $-1,109$ & 0,2693 & \\
\hline PLMP_expend & 1,95467 & 0,463723 & 4,215 & $4,47 \mathrm{E}-05$ & $* * *$ \\
\hline PLMP_expend_1 & 0,0494887 & 0,514994 & 0,0961 & 0,9236 & \\
\hline GDP_per_cap & $3,71 \mathrm{E}-05$ & 0,0001262 & 0,2938 & 0,7693 & \\
\hline GDP_per_cap_1 & $8,73 \mathrm{E}-05$ & 0,0001452 & 0,6015 & 0,5485 & \\
\hline GDP_growth & $-0,133640$ & 0,0554356 & $-2,411$ & 0,0172 & $* *$ \\
\hline GDP_growth_1 & 0,0357333 & 0,0593463 & 0,6021 & 0,5481 & \\
\hline HICP & 0,0728639 & 0,0860877 & 0,8464 & 0,3988 & \\
\hline HICP_1 & $-0,0202525$ & 0,0726447 & $-0,2788$ & 0,7808 & \\
\hline adult_unemp_rate_1 & 0,617672 & 0,0656312 & 9,411 & $1,41 \mathrm{E}-16$ & $* * *$ \\
\hline Mean dependent var & 7,133326 & & S.D. depen & dent var & 3,488606 \\
\hline Sum squared resid & 75,12073 & & S.E. of regr & ession & 0,735144 \\
\hline LSDV R-squared & 0,968347 & & Within R-s & quared & 0,856927 \\
\hline LSDV F(56, 139) & 75,93401 & & P-value(F) & & $1,60 \mathrm{E}-81$ \\
\hline Log-likelihood & $-184,1282$ & & Akaike crit & erion & 482,2564 \\
\hline Schwarz criterion & 669,1089 & & Hannan-Qu & inn & 557,9032 \\
\hline rho & $-0,099159$ & & Durbin-Wa & tson & 1,803588 \\
\hline
\end{tabular}


Joint test on named regressors -

Test statistic: $\mathrm{F}(29,139)=28,7079$

with $\mathrm{p}$-value $=\mathrm{P}(\mathrm{F}(29,139)>28,7079)=3,1456 \mathrm{e}-045$

Test for differing group intercepts -

Null hypothesis: The groups have a common intercept

Test statistic: $F(27,139)=3,08518$

with p-value $=\mathrm{P}(\mathrm{F}(27,139)>3,08518)=8,5774 \mathrm{e}-006$

Megjegyzés: * jelöli a 10 százalékos, ** az 5 százalékos, *** pedig az 1 százalékos szinten szignifikáns hatással bíró változókat.

Forrás: saját szerkesztés.

9. Az 55-64 éves korosztály foglalkoztatási rátáját befolyásoló tényezők

\begin{tabular}{|c|c|c|c|c|c|}
\hline \multicolumn{6}{|c|}{$\begin{array}{l}\text { FE, } 196 \text { megfigyelés ( } 28 \text { ország, idősor hossza: } 7 \text { év) } \\
\text { Függó változó: idősebbek foglalkoztatási rátája }\end{array}$} \\
\hline & együttható & standard hiba & t-arány & p-érték & \\
\hline const & 15,7742 & 16,5634 & 0,9524 & 0,3424 & \\
\hline min_wage & $-4,38078$ & 7,09202 & $-0,6177$ & 0,5377 & \\
\hline tax_wedge & $-0,276955$ & 0,0942156 & $-2,940$ & 0,0038 & $* * *$ \\
\hline trade_union_dens & 0,0176372 & 0,0248895 & 0,7086 & 0,4796 & \\
\hline part_timers & 0,465254 & 0,171625 & 2,711 & 0,0075 & $* * *$ \\
\hline invol_part_timers & $-0,0211007$ & 0,0313355 & $-0,6734$ & 0,5017 & \\
\hline hours_worked & $-0,189082$ & 0,350679 & $-0,5392$ & 0,5905 & \\
\hline temporary_emp & $-0,0467443$ & 0,0860394 & $-0,5433$ & 0,5877 & \\
\hline EPL_regular & 1,75342 & 0,892614 & 1,964 & 0,0513 & $*$ \\
\hline EPL_temporary & $-0,259957$ & 0,37049 & $-0,7017$ & 0,484 & \\
\hline ALMP_expend & 2,47224 & 1,45735 & 1,696 & 0,0918 & $*$ \\
\hline PLMP_expend & $-1,42127$ & 0,789406 & $-1,800$ & 0,0738 & $*$ \\
\hline GDP_per_cap & $-9,97679 \mathrm{e}-05$ & 7,59E-05 & $-1,315$ & 0,1905 & \\
\hline GDP_growth & 0,142886 & 0,0465911 & 3,067 & 0,0026 & $* * *$ \\
\hline HICP & 0,0208116 & 0,0594 & 0,3504 & 0,7265 & \\
\hline old_emp_rate_1 & 0,586273 & 0,058364 & 10,05 & $1,50 \mathrm{E}-18$ & $* * *$ \\
\hline Mean dependent var & \multicolumn{2}{|l|}{41,17714} & \multicolumn{2}{|c|}{ S.D. dependent var } & 11,38902 \\
\hline Sum squared resid & \multicolumn{2}{|l|}{346,6736} & \multicolumn{2}{|c|}{ S.E. of regression } & 1,505271 \\
\hline LSDV R-squared & \multicolumn{2}{|l|}{0,986294} & \multicolumn{2}{|c|}{ Within R-squared } & 0,844256 \\
\hline LSDV F(42, 153) & \multicolumn{2}{|l|}{262,1412} & \multicolumn{2}{|l|}{ P-value(F) } & $5,50 \mathrm{E}-123$ \\
\hline Log-likelihood & \multicolumn{2}{|l|}{$-333,9983$} & \multicolumn{2}{|c|}{ Akaike criterion } & 753,9966 \\
\hline Schwarz criterion & \multicolumn{2}{|l|}{894,9556} & \multicolumn{2}{|c|}{ Hannan-Quinn } & 811,0636 \\
\hline rho & \multicolumn{2}{|l|}{$-0,199425$} & \multicolumn{2}{|c|}{ Durbin-Watson } & 1,94648 \\
\hline \multicolumn{6}{|c|}{$\begin{array}{l}\text { Joint test on named regressors - } \\
\text { Test statistic: } \mathrm{F}(15,153)=55,2922 \\
\text { with p-value }=\mathrm{P}(\mathrm{F}(15,153)>55,2922)=7,14918 \mathrm{e}-054\end{array}$} \\
\hline \multicolumn{6}{|c|}{$\begin{array}{l}\text { Test for differing group intercepts - } \\
\text { Null hypothesis: The groups have a common intercept } \\
\text { Test statistic: } \mathrm{F}(27,153)=4,59878 \\
\text { with p-value }=\mathrm{P}(\mathrm{F}(27,153)>4,59878)=5,76086 \mathrm{e}-010\end{array}$} \\
\hline
\end{tabular}

Megjegyzés: * jelöli a 10 százalékos, ** az 5 százalékos, *** pedig az 1 százalékos szinten szignifikáns hatással bíró változókat.

Forrás: saját szerkesztés. 
10. Az 55-64 éves korosztály munkanélküliségi rátáját befolyásoló tényezők

\begin{tabular}{|c|c|c|c|c|c|}
\hline \multicolumn{6}{|c|}{\begin{tabular}{|l|} 
FE, 196 megfigyelés ( 28 ország, idősor hossza: 7 év) \\
Függő változó: idősebbek munkanélküliségi rátája
\end{tabular}} \\
\hline & együttható & standard hiba & t-arány & p-érték & \\
\hline const & 40,1013 & 11,7363 & 3,417 & 0,0008 & $* * *$ \\
\hline min_wage & $-16,2547$ & 4,52337 & $-3,593$ & 0,0005 & $* * *$ \\
\hline min_wage_1 & 8,24825 & 3,50411 & 2,354 & 0,02 & $* *$ \\
\hline tax_wedge & $-0,0287665$ & 0,060872 & $-0,4726$ & 0,6373 & \\
\hline tax_wedge_1 & 0,133293 & 0,0617754 & 2,158 & 0,0327 & $* *$ \\
\hline trade_union_dens & $-0,0188924$ & 0,0155938 & $-1,212$ & 0,2277 & \\
\hline trade_union_dens_1 & 0,0072627 & 0,0176617 & 0,4112 & 0,6815 & \\
\hline part_timers & 0,137697 & 0,143388 & 0,9603 & 0,3386 & \\
\hline part_timers_1 & $-0,253224$ & 0,136465 & $-1,856$ & 0,0656 & $*$ \\
\hline invol_part_timers & 0,0451384 & 0,0186833 & 2,416 & 0,017 & $* *$ \\
\hline invol_part_timers_1 & $-0,0381130$ & 0,0195423 & $-1,950$ & 0,0532 & $*$ \\
\hline hours_worked & $-0,572659$ & 0,237477 & $-2,411$ & 0,0172 & $* *$ \\
\hline hours_worked_1 & $-0,247855$ & 0,223462 & $-1,109$ & 0,2693 & \\
\hline temporary_emp & -0,0279159 & 0,0714718 & -0,3906 & 0,6967 & \\
\hline temporary_emp_1 & $-0,0495945$ & 0,0797694 & \begin{tabular}{|c|}
$-0,6217$ \\
\end{tabular} & 0,5351 & \\
\hline EPL_regular & $-1,60982$ & 0,595013 & $-2,706$ & 0,0077 & $* * *$ \\
\hline EPL_regular_1 & 1,12646 & 0,650493 & 1,732 & 0,0855 & * \\
\hline EPL_temporary & 0,392702 & 0,256555 & 1,531 & 0,1281 & \\
\hline EPL_temporary_1 & 0,187235 & 0,255655 & 0,7324 & 0,4652 & \\
\hline ALMP_expend & 0,403837 & 1,07521 & 0,3756 & 0,7078 & \\
\hline ALMP_expend_1 & $-1,33084$ & 1,05762 & $-1,258$ & 0,2104 & \\
\hline PLMP_expend & 0,231412 & 0,513351 & 0,4508 & 0,6528 & \\
\hline PLMP_expend_1 & 1,25682 & 0,531447 & 2,365 & 0,0194 & $* *$ \\
\hline GDP_per_cap & $-2,74402 \mathrm{e}-06$ & 0,0001391 & $-0,01973$ & 0,9843 & \\
\hline GDP_per_cap_1 & $9,94 \mathrm{E}-05$ & 0,0001604 & 0,6195 & 0,5366 & \\
\hline GDP_growth & $-0,127537$ & 0,0615705 & $-2,071$ & 0,0402 & $* *$ \\
\hline GDP_growth_1 & 0,0014742 & 0,0655655 & 0,02248 & 0,9821 & \\
\hline HICP & 0,0303522 & 0,0940524 & 0,3227 & 0,7474 & \\
\hline HICP_1 & 0,0432084 & 0,0791696 & 0,5458 & 0,5861 & \\
\hline old_unemp_rate_1 & 0,370184 & 0,0706509 & 5,24 & $5,84 \mathrm{E}-07$ & $* * *$ \\
\hline Mean dependent var & 5,542968 & & S.D. depend & dent var & 3,286955 \\
\hline Sum squared resid & 91,709 & & S.E. of regre & ession & 0,812267 \\
\hline LSDV R-squared & 0,95647 & & Within R-sq & quared & 0,757906 \\
\hline LSDV F $(56,139)$ & 54,53914 & & P-value(F) & & $4,77 \mathrm{E}-72$ \\
\hline Log-likelihood & $-203,6815$ & & Akaike crite & erion & 521,3631 \\
\hline Schwarz criterion & 708,2156 & & Hannan-Qui & & 597,0099 \\
\hline rho & $-0,055091$ & & Durbin-Wat & tson & 1,800764 \\
\hline
\end{tabular}

Joint test on named regressors -

Test statistic: $\mathrm{F}(29,139)=15,0054$

with $\mathrm{p}$-value $=\mathrm{P}(\mathrm{F}(29,139)>15,0054)=4,64032 \mathrm{e}-030$

Test for differing group intercepts -

Null hypothesis: The groups have a common intercept

Test statistic: $\mathrm{F}(27,139)=3,25853$

with $\mathrm{p}$-value $=\mathrm{P}(\mathrm{F}(27,139)>3,25853)=3,0155 \mathrm{e}-006$

Megjegyzés: * jelöli a 10 százalékos, ** az 5 százalékos, ${ }^{* * *}$ pedig az 1 százalékos szinten szignifikáns hatással bíró változókat.

Forrás: saját szerkesztés. 


\section{A MÁSODIK IDÖSZAKRA (2008-2015) ELVÉGZETT PANEL REGRESSZIÓK EREDMÉNYEI (GRETL)}

1. A teljes foglalkoztatási rátát befolyásoló tényezők

\begin{tabular}{|c|c|c|c|c|c|}
\hline \multicolumn{6}{|c|}{$\begin{array}{l}\text { FE, } 168 \text { megfigyelés ( } 28 \text { ország, idősor hossza: } 6 \text { év) } \\
\text { Függő változó: teljes foglalkoztatási ráta }\end{array}$} \\
\hline & együttható & standard hiba & t-arány & p-érték & \\
\hline const & 4,16049 & 16,2446 & 0,2561 & 0,7984 & \\
\hline min_wage & 6,58277 & 4,67555 & 1,408 & 0,1624 & \\
\hline min_wage_1 & $-7,46047$ & 4,34927 & $-1,715$ & 0,0895 & $*$ \\
\hline min_wage_2 & $-1,37957$ & 3,67078 & $-0,3758$ & 0,7079 & \\
\hline tax_wedge & 0,10796 & 0,0464883 & 2,322 & 0,0223 & $* *$ \\
\hline tax_wedge_1 & $-0,0298210$ & 0,0560047 & $-0,5325$ & 0,5956 & \\
\hline tax_wedge_2 & $-0,0147009$ & 0,0522811 & $-0,2812$ & 0,7792 & \\
\hline trade_union_dens & 0,0306297 & 0,0105404 & 2,906 & 0,0045 & *** \\
\hline trade_union_dens_1 & $-0,0343492$ & 0,0136405 & $-2,518$ & 0,0135 & $* *$ \\
\hline trade_union_dens_2 & $-0,0286268$ & 0,0227758 & $-1,257$ & 0,2118 & \\
\hline part_timers & 0,158223 & 0,143796 & 1,1 & 0,2739 & \\
\hline part_timers_1 & $-0,125603$ & 0,150547 & $-0,8343$ & 0,4062 & \\
\hline part_timers_2 & 0,133732 & 0,112311 & 1,191 & 0,2367 & \\
\hline invol_part_timers & $-0,0156818$ & 0,0219108 & $-0,7157$ & 0,4759 & \\
\hline invol_part_timers_1 & $-0,0119458$ & 0,0211831 & $-0,5639$ & 0,5741 & \\
\hline invol_part_timers_2 & $-0,00153504$ & 0,0189925 & $-0,08082$ & 0,9358 & \\
\hline hours_worked & 0,707648 & 0,445172 & 1,59 & 0,1152 & \\
\hline hours_worked_1 & 0,597825 & 0,536966 & 1,113 & 0,2683 & \\
\hline hours_worked_2 & $-1,07884$ & 0,381094 & $-2,831$ & 0,0057 & $* * *$ \\
\hline temporary_emp & 0,198295 & 0,0731372 & 2,711 & 0,0079 & $* * *$ \\
\hline temporary_emp_1 & $-0,123682$ & 0,10048 & $-1,231$ & 0,2214 & \\
\hline temporary_emp_2 & 0,073316 & 0,0795518 & 0,9216 & 0,359 & \\
\hline EPL_regular & 0,694943 & 0,362583 & 1,917 & 0,0583 & $*$ \\
\hline EPL_regular_1 & $-0,255651$ & 0,397638 & $-0,6429$ & 0,5218 & \\
\hline EPL_regular_2 & $-0,191523$ & 0,469684 & $-0,4078$ & 0,6844 & \\
\hline EPL_temporary & $-0,0477112$ & 0,1889 & $-0,2526$ & 0,8011 & \\
\hline EPL_temporary_1 & $-0,0181439$ & 0,237763 & $-0,07631$ & 0,9393 & \\
\hline EPL_temporary_2 & $-0,0545030$ & 0,296435 & $-0,1839$ & 0,8545 & \\
\hline ALMP_expend & $-0,200146$ & 0,772086 & $-0,2592$ & 0,796 & \\
\hline ALMP_expend_1 & 0,287139 & 0,792501 & 0,3623 & 0,7179 & \\
\hline ALMP_expend_2 & $-1,20440$ & 0,699643 & $-1,721$ & 0,0884 & $*$ \\
\hline PLMP_expend & $-0,665025$ & 0,373745 & $-1,779$ & 0,0783 & $*$ \\
\hline PLMP_expend_1 & $-1,03573$ & 0,433295 & $-2,390$ & 0,0188 & $* *$ \\
\hline PLMP_expend_2 & 0,485936 & 0,383773 & 1,266 & 0,2085 & \\
\hline GDP_per_cap & $-0,000258182$ & $7,65 \mathrm{E}-05$ & $-3,376$ & 0,0011 & $* * *$ \\
\hline GDP_per_cap_1 & 0,0001407 & $7,85 \mathrm{E}-05$ & 1,793 & 0,0761 & $*$ \\
\hline GDP_per_cap_2 & $4,56 \mathrm{E}-05$ & $5,58 \mathrm{E}-05$ & 0,8166 & 0,4162 & \\
\hline GDP_growth & 0,115357 & 0,0374863 & 3,077 & 0,0027 & $* * *$ \\
\hline GDP_growth_1 & $-0,0439445$ & 0,0497883 & $-0,8826$ & 0,3796 & \\
\hline GDP_growth_2 & $-0,0451679$ & 0,0288494 & $-1,566$ & 0,1207 & \\
\hline HICP & $-0,0192309$ & 0,0794592 & $-0,2420$ & 0,8093 & \\
\hline HICP_1 & $-0,147709$ & 0,0929938 & $-1,588$ & 0,1155 & \\
\hline HICP_2 & 0,162784 & 0,0551413 & 2,952 & 0,004 & $* * *$ \\
\hline total_emp_rate_1 & 0,770099 & 0,08352 & 9,221 & $7,04 \mathrm{E}-15$ & $* * *$ \\
\hline total_emp_rate_2 & $-0,0569588$ & 0,0734279 & $-0,7757$ & 0,4398 & \\
\hline
\end{tabular}




\begin{tabular}{|lrlr|}
\hline Mean dependent var & 52,90867 & S.D. dependent var & 5,93765 \\
Sum squared resid & 21,84477 & S.E. of regression & 0,477022 \\
LSDV R-squared & 0,99629 & Within R-squared & 0,942135 \\
LSDV F(71, 96) & 363,0753 & P-value(F) & $3,79 E-94$ \\
Log-likelihood & $-67,02147$ & Akaike criterion & 278,0429 \\
Schwarz criterion & 502,9684 & Hannan-Quinn & 369,3286 \\
rho & $-0,410146$ & Durbin-Watson & 2,330129 \\
\hline
\end{tabular}

Joint test on named regressors -

Test statistic: $F(44,96)=35,5238$

with $\mathrm{p}$-value $=\mathrm{P}(\mathrm{F}(44,96)>35,5238)=3,12466 \mathrm{e}-043$

Test for differing group intercepts -

Null hypothesis: The groups have a common intercept

Test statistic: $\mathrm{F}(27,96)=3,4114$

with p-value $=\mathrm{P}(\mathrm{F}(27,96)>3,4114)=5,19025 \mathrm{e}-006$

Megjegyzés: * jelöli a 10 százalékos, ** az 5 százalékos, *** pedig az 1 százalékos szinten szignifikáns hatással bíró változókat.

Forrás: saját szerkesztés.

2. A teljes munkanélküliségi rátát befolyásoló tényezők

FE, 168 megfigyelés (28 ország, idősor hossza: 6 év)

Függő változó: teljes munkanélküliségi ráta

\begin{tabular}{|c|c|c|c|c|c|}
\hline & együttható & standard hiba & t-arány & p-érték & \\
\hline const & 22,1639 & 19,221 & 1,153 & 0,2517 & \\
\hline min_wage & 0,0146348 & 5,77636 & 0,002534 & 0,998 & \\
\hline min_wage_1 & 9,25148 & 5,31283 & 1,741 & 0,0848 & $*$ \\
\hline min_wage_2 & 3,72094 & 4,47508 & 0,8315 & 0,4078 & \\
\hline tax_wedge & $-0,128568$ & 0,0566192 & $-2,271$ & 0,0254 & $* *$ \\
\hline tax_wedge_1 & 0,106831 & 0,0673283 & 1,587 & 0,1159 & \\
\hline tax_wedge_2 & 0,126651 & 0,0638361 & 1,984 & 0,0501 & $*$ \\
\hline trade_union_dens & $-0,0219747$ & 0,013034 & $-1,686$ & 0,0951 & $*$ \\
\hline trade_union_dens_1 & 0,0292753 & 0,0163375 & 1,792 & 0,0763 & $*$ \\
\hline trade_union_dens_2 & 0,0276508 & 0,0279983 & 0,9876 & 0,3258 & \\
\hline part_timers & 0,0975689 & 0,175937 & 0,5546 & 0,5805 & \\
\hline part_timers_1 & $-0,260707$ & 0,180829 & $-1,442$ & 0,1526 & \\
\hline part_timers_2 & $-0,115235$ & 0,141546 & $-0,8141$ & 0,4176 & \\
\hline invol_part_timers & 0,0171912 & 0,0266068 & 0,6461 & 0,5197 & \\
\hline invol_part_timers_1 & 0,0292305 & 0,0260729 & 1,121 & 0,265 & \\
\hline invol_part_timers_2 & $-0,0401113$ & 0,0234349 & $-1,712$ & 0,0902 & $*$ \\
\hline hours_worked & $-0,685811$ & 0,551811 & $-1,243$ & 0,217 & \\
\hline hours_worked_1 & $-1,23424$ & 0,629501 & $-1,961$ & 0,0528 & $*$ \\
\hline hours_worked_2 & 1,19643 & 0,44346 & 2,698 & 0,0082 & $* * *$ \\
\hline temporary_emp & $-0,190723$ & 0,093221 & $-2,046$ & 0,0435 & $* *$ \\
\hline temporary_emp_1 & 0,0269092 & 0,122389 & 0,2199 & 0,8264 & \\
\hline temporary_emp_2 & 0,136644 & 0,0990368 & 1,38 & 0,1709 & \\
\hline EPL_regular & $-0,893535$ & 0,442117 & $-2,021$ & 0,0461 & $* *$ \\
\hline EPL_regular_1 & $-0,106137$ & 0,485095 & $-0,2188$ & 0,8273 & \\
\hline EPL_regular_2 & 1,66327 & 0,573627 & 2,9 & 0,0046 & $* * *$ \\
\hline EPL_temporary & $-0,0698731$ & 0,230283 & $-0,3034$ & 0,7622 & \\
\hline EPL_temporary_1 & $-0,0235166$ & 0,286559 & $-0,08207$ & 0,9348 & \\
\hline EPL_temporary_2 & $-0,0501973$ & 0,358215 & $-0,1401$ & 0,8888 & \\
\hline ALMP_expend & 0,103519 & 0,932415 & 0,111 & 0,9118 & \\
\hline ALMP_expend_1 & $-0,0327428$ & 0,961981 & $-0,03404$ & 0,9729 & \\
\hline ALMP_expend_2 & 1,34442 & 0,850419 & 1,581 & 0,1172 & \\
\hline PLMP_expend & 1,09462 & 0,457582 & 2,392 & 0,0187 & $* *$ \\
\hline
\end{tabular}




\begin{tabular}{|c|c|c|c|c|c|}
\hline PLMP_expend_1 & 0,856549 & 0,538527 & 1,591 & 0,115 & \\
\hline PLMP_expend_2 & $-0,579035$ & 0,462156 & $-1,253$ & 0,2133 & \\
\hline GDP_per_cap & 0,0003065 & $9,38 \mathrm{E}-05$ & 3,268 & 0,0015 & $* * *$ \\
\hline GDP_per_cap_1 & $-9,62011 \mathrm{e}-05$ & $9,64 \mathrm{E}-05$ & $-0,9984$ & 0,3206 & \\
\hline GDP_per_cap_2 & $-7,43943 e-05$ & $6,84 \mathrm{E}-05$ & $-1,087$ & 0,2798 & \\
\hline GDP_growth & $-0,182142$ & 0,0458816 & $-3,970$ & 0,0001 & $* * *$ \\
\hline GDP_growth_1 & 0,0726945 & 0,0591386 & 1,229 & 0,222 & \\
\hline GDP_growth_2 & 0,0640578 & 0,0356914 & 1,795 & 0,0758 & $*$ \\
\hline $\mathrm{HICP}$ & 0,0148232 & 0,0960768 & 0,1543 & 0,8777 & \\
\hline HICP_1 & 0,17535 & 0,113745 & 1,542 & 0,1265 & \\
\hline HICP_2 & $-0,201902$ & 0,0663151 & $-3,045$ & 0,003 & $* * *$ \\
\hline total_unemp_rate_1 & 0,801676 & 0,0761702 & 10,52 & $1,11 \mathrm{E}-17$ & $* * *$ \\
\hline total_unemp_rate_2 & $-0,0313919$ & 0,0709582 & $-0,4424$ & 0,6592 & \\
\hline Mean dependent var & \multicolumn{2}{|l|}{10,33718} & \multicolumn{2}{|c|}{ S.D. dependent var } & 4,901002 \\
\hline Sum squared resid & \multicolumn{2}{|l|}{32,53759} & \multicolumn{2}{|c|}{ S.E. of regression } & 0,58218 \\
\hline LSDV R-squared & \multicolumn{2}{|l|}{0,991889} & \multicolumn{2}{|c|}{ Within R-squared } & 0,948995 \\
\hline LSDV F(71, 96) & \multicolumn{2}{|l|}{165,3395} & \multicolumn{2}{|l|}{ P-value(F) } & $6,59 \mathrm{E}-78$ \\
\hline Log-likelihood & \multicolumn{2}{|l|}{$-100,4900$} & \multicolumn{2}{|c|}{ Akaike criterion } & 344,98 \\
\hline Schwarz criterion & \multicolumn{2}{|l|}{569,9054} & \multicolumn{2}{|c|}{ Hannan-Quinn } & 436,2656 \\
\hline rho & \multicolumn{2}{|l|}{$-0,199257$} & \multicolumn{2}{|c|}{ Durbin-Watson } & 1,980288 \\
\hline \multicolumn{6}{|c|}{$\begin{array}{l}\text { Joint test on named regressors - } \\
\text { Test statistic: } \mathrm{F}(44,96)=40,5944 \\
\text { with p-value }=\mathrm{P}(\mathrm{F}(44,96)>40,5944)=8,49695 \mathrm{e}-046\end{array}$} \\
\hline \multicolumn{6}{|c|}{$\begin{array}{l}\text { Test for differing group intercepts - } \\
\text { Null hypothesis: The groups have a common intercept } \\
\text { Test statistic: } F(27,96)=3,82717 \\
\text { with p-value }=P(F(27,96)>3,82717)=6,32441 \mathrm{e}-007\end{array}$} \\
\hline
\end{tabular}

Megjegyzés: * jelöli a 10 százalékos, ** az 5 százalékos, *** pedig az 1 százalékos szinten szignifikáns hatással bíró változókat.

Forrás: saját szerkesztés.

3. Az ifjúsági foglalkoztatási rátát befolyásoló tényezők

FE, 168 megfigyelés (28 ország, idősor hossza: 6 év)

Függő változó: ifjúsági foglalkoztatási ráta

\begin{tabular}{|l|r|r|r|r|r|}
\hline & együttható & standard hiba & t-arány & p-érték & \\
\hline const & $-20,3166$ & 37,3185 & $-0,5444$ & 0,5874 & \\
\hline min_wage & 15,1178 & 11,0552 & 1,367 & 0,1747 & \\
\hline min_wage_1 & $-20,0380$ & 10,2335 & $-1,958$ & 0,0531 & $*$ \\
\hline min_wage_2 & 15,4025 & 8,81242 & 1,748 & 0,0837 & $*$ \\
\hline tax_wedge & 0,166175 & 0,110201 & 1,508 & 0,1349 & \\
\hline tax_wedge_1 & $-0,0169679$ & 0,130696 & $-0,1298$ & 0,897 & \\
\hline tax_wedge_2 & $-0,0458838$ & 0,123493 & $-0,3716$ & 0,711 & \\
\hline trade_union_dens & $-0,0303060$ & 0,025222 & $-1,202$ & 0,2325 & \\
\hline trade_union_dens_1 & 0,0800016 & 0,0321032 & 2,492 & 0,0144 & $* *$ \\
\hline trade_union_dens_2 & $-0,0134352$ & 0,0525421 & $-0,2557$ & 0,7987 & \\
\hline part_timers & 0,424661 & 0,339897 & 1,249 & 0,2146 & \\
\hline part_timers_1 & $-0,399696$ & 0,359114 & $-1,113$ & 0,2685 & \\
\hline part_timers_2 & 0,397017 & 0,268235 & 1,48 & 0,1421 & \\
\hline invol_part_timers & 0,0119881 & 0,0515293 & 0,2326 & 0,8165 & \\
\hline invol_part_timers_1 & 0,0292542 & 0,0507623 & 0,5763 & 0,5658 & \\
\hline invol_part_timers_2 & 0,0083129 & 0,0445744 & 0,1865 & 0,8525 & \\
\hline hours_worked & 0,883556 & 1,04975 & 0,8417 & 0,4021 & \\
\hline hours_worked_1 & 1,16214 & 1,24198 & 0,9357 & 0,3518 & \\
\hline
\end{tabular}




\begin{tabular}{|c|c|c|c|c|c|c|}
\hline hours_worked_2 & $-1,41145$ & 0,88922 & $-1,587$ & 0,1157 & & \\
\hline temporary_emp & 0,610585 & 0,171278 & 3,565 & 0,0006 & $* * *$ & \\
\hline temporary_emp_1 & $-0,443421$ & 0,238579 & $-1,859$ & 0,0661 & $*$ & \\
\hline temporary_emp_2 & 0,209089 & 0,191306 & 1,093 & 0,2771 & & \\
\hline EPL_regular & 1,98048 & 0,857864 & 2,309 & 0,0231 & $* *$ & \\
\hline EPL_regular_1 & $-2,36709$ & 0,948355 & $-2,496$ & 0,0143 & $* *$ & \\
\hline EPL_regular_2 & 1,98974 & 1,07874 & 1,844 & 0,0682 & $*$ & \\
\hline EPL_temporary & $-1,28775$ & 0,446687 & $-2,883$ & 0,0049 & $* * *$ & \\
\hline EPL_temporary_1 & 0,671647 & 0,570164 & 1,178 & 0,2417 & & \\
\hline EPL_temporary_2 & 0,461402 & 0,673784 & 0,6848 & 0,4951 & & \\
\hline ALMP_expend & 0,98955 & 1,86501 & 0,5306 & 0,5969 & & \\
\hline ALMP_expend_1 & 0,270686 & 1,87675 & 0,1442 & 0,8856 & & \\
\hline ALMP_expend_2 & $-3,77477$ & 1,6492 & $-2,289$ & 0,0243 & $* *$ & \\
\hline PLMP_expend & $-1,56554$ & 0,932801 & $-1,678$ & 0,0965 & $*$ & \\
\hline PLMP_expend_1 & $-0,692500$ & 0,97909 & $-0,7073$ & 0,4811 & & \\
\hline PLMP_expend_2 & $-0,670657$ & 0,894494 & $-0,7498$ & 0,4552 & & \\
\hline GDP_per_cap & $-0,000347206$ & 0,0001804 & $-1,924$ & 0,0573 & $*$ & \\
\hline GDP_per_cap_1 & 0,0002508 & 0,0001885 & 1,33 & 0,1865 & & \\
\hline GDP_per_cap_2 & 0,0001899 & 0,0001329 & 1,429 & 0,1561 & & \\
\hline GDP_growth & 0,0909141 & 0,0894937 & 1,016 & 0,3122 & & \\
\hline GDP_growth_1 & 0,185706 & 0,11573 & 1,605 & 0,1119 & & \\
\hline GDP_growth_2 & $-0,205931$ & 0,0703862 & $-2,926$ & 0,0043 & $* * *$ & \\
\hline HICP & $-0,240499$ & 0,190022 & $-1,266$ & 0,2087 & & \\
\hline HICP_1 & 0,0051093 & 0,220804 & 0,02314 & 0,9816 & & \\
\hline HICP_2 & 0,0348643 & 0,13418 & 0,2598 & 0,7955 & & \\
\hline youth_emp_rate_1 & 0,562792 & 0,0898218 & 6,266 & $1,05 \mathrm{E}-08$ & $* * *$ & \\
\hline youth_emp_rate_2 & 0,0069416 & 0,0848093 & 0,08185 & 0,9349 & & \\
\hline Mean dependent var & 31,43739 & & S.D. depende & t var & & 12,74388 \\
\hline Sum squared resid & 122,1385 & & S.E. of regres & ion & & 1,127952 \\
\hline LSDV R-squared & 0,995497 & & Within R-squ & ared & & 0,847568 \\
\hline $\operatorname{LSDV} F(71,96)$ & 298,8961 & & P-value(F) & & & 4,02E-90 \\
\hline Log-likelihood & $-211,6018$ & & Akaike criteri & & & 567,2035 \\
\hline Schwarz criterion & 792,1289 & & Hannan-Quin & & & 658,4892 \\
\hline rho & $-0,217585$ & & Durbin-Watsc & & & 2,038343 \\
\hline \multicolumn{7}{|c|}{$\begin{array}{l}\text { Joint test on named regressors - } \\
\text { Test statistic: } F(44,96)=12,1316 \\
\text { with p-value }=\mathrm{P}(\mathrm{F}(44,96)>12,1316)=5,55845 \mathrm{e}-024\end{array}$} \\
\hline \multicolumn{7}{|c|}{$\begin{array}{l}\text { Test for differing group intercepts - } \\
\text { Null hypothesis: The groups have a common intercept } \\
\text { Test statistic: } \mathrm{F}(27,96)=3,22534 \\
\text { with p-value }=\mathrm{P}(\mathrm{F}(27,96)>3,22534)=1,35003 \mathrm{e}-005\end{array}$} \\
\hline
\end{tabular}

Megjegyzés: * jelöli a 10 százalékos, ** az 5 százalékos, *** pedig az 1 százalékos szinten szignifikáns hatással bíró változókat.

Forrás: saját szerkesztés.

4. Az ifjúsági munkanélküliségi rátát befolyásoló tényezők

FE, 168 megfigyelés (28 ország, idősor hossza: 6 év)

Függő változó: ifjúsági munkanélküliségi ráta

\begin{tabular}{|l|r|r|r|r|r|}
\hline & együttható & standard hiba & t-arány & p-érték & \\
\hline const & 28,0464 & 54,9475 & 0,5104 & 0,6109 & \\
\hline min_wage & $-0,388737$ & 16,3646 & $-0,02375$ & 0,9811 & \\
\hline min_wage_1 & 33,0284 & 15,1507 & 2,18 & 0,0317 & $* *$ \\
\hline min_wage_2 & $-1,99115$ & 12,9876 & $-0,1533$ & 0,8785 & \\
\hline
\end{tabular}




\begin{tabular}{|c|c|c|c|c|c|c|}
\hline tax_wedge & $-0,354102$ & 0,16174 & $-2,189$ & 0,031 & $* *$ & \\
\hline tax_wedge_1 & 0,377231 & 0,191965 & 1,965 & 0,0523 & $*$ & \\
\hline tax_wedge_2 & 0,0936351 & 0,185725 & 0,5042 & 0,6153 & & \\
\hline trade_union_dens & 0,038231 & 0,0373283 & 1,024 & 0,3083 & & \\
\hline trade_union_dens_1 & $-0,0395084$ & 0,0473119 & $-0,8351$ & 0,4058 & & \\
\hline trade_union_dens_2 & 0,109109 & 0,0782782 & 1,394 & 0,1666 & & \\
\hline part_timers & 0,77134 & 0,500744 & 1,54 & 0,1268 & & \\
\hline part_timers_1 & $-0,947656$ & 0,515238 & $-1,839$ & 0,069 & $*$ & \\
\hline part_timers_2 & $-0,211562$ & 0,403359 & $-0,5245$ & 0,6011 & & \\
\hline invol_part_timers & 0,122006 & 0,0751086 & 1,624 & 0,1076 & & \\
\hline invol_part_timers_1 & $-0,0167306$ & 0,0756534 & $-0,2211$ & 0,8254 & & \\
\hline invol_part_timers_2 & $-0,0670364$ & 0,068637 & $-0,9767$ & 0,3312 & & \\
\hline hours_worked & 1,59718 & 1,56158 & 1,023 & 0,309 & & \\
\hline hours_worked_1 & $-5,78733$ & 1,76374 & $-3,281$ & 0,0014 & $* * *$ & \\
\hline hours_worked_2 & 3,2657 & 1,25474 & 2,603 & 0,0107 & $* *$ & \\
\hline temporary_emp & $-0,415991$ & 0,263013 & $-1,582$ & 0,117 & & \\
\hline temporary_emp_1 & $-0,143626$ & 0,346523 & $-0,4145$ & 0,6795 & & \\
\hline temporary_emp_2 & 0,373578 & 0,276656 & 1,35 & 0,1801 & & \\
\hline EPL_regular & $-3,03939$ & 1,271 & $-2,391$ & 0,0187 & $* *$ & \\
\hline EPL_regular_1 & 2,29276 & 1,43103 & 1,602 & 0,1124 & & \\
\hline EPL_regular_2 & 0,851832 & 1,64856 & 0,5167 & 0,6065 & & \\
\hline EPL_temporary & 0,920097 & 0,655542 & 1,404 & 0,1637 & & \\
\hline EPL_temporary_1 & $-0,415537$ & 0,813196 & $-0,5110$ & 0,6105 & & \\
\hline EPL_temporary_2 & 0,435072 & 1,00133 & 0,4345 & 0,6649 & & \\
\hline ALMP_expend & $-1,13997$ & 2,67619 & $-0,4260$ & 0,6711 & & \\
\hline ALMP_expend_1 & $-2,98985$ & 2,75508 & $-1,085$ & 0,2805 & & \\
\hline ALMP_expend_2 & 5,57354 & 2,4532 & 2,272 & 0,0253 & $* *$ & \\
\hline PLMP_expend & 2,47222 & 1,32941 & 1,86 & 0,066 & $*$ & \\
\hline PLMP_expend_1 & 1,12699 & 1,48394 & 0,7595 & 0,4494 & & \\
\hline PLMP_expend_2 & 0,50808 & 1,28538 & 0,3953 & 0,6935 & & \\
\hline GDP_per_cap & 0,0007197 & 0,0002679 & 2,687 & 0,0085 & $* * *$ & \\
\hline GDP_per_cap_1 & $-0,000132820$ & 0,0002783 & $-0,4772$ & 0,6343 & & \\
\hline GDP_per_cap_2 & $-0,000273078$ & 0,0001949 & $-1,401$ & 0,1643 & & \\
\hline GDP_growth & $-0,436960$ & 0,131087 & $-3,333$ & 0,0012 & $* * *$ & \\
\hline GDP_growth_1 & 0,113772 & 0,169238 & 0,6723 & 0,503 & & \\
\hline GDP_growth_2 & 0,170147 & 0,102167 & 1,665 & 0,0991 & $*$ & \\
\hline HICP & 0,278872 & 0,280798 & 0,9931 & 0,3231 & & \\
\hline HICP_1 & $-0,0127810$ & 0,32441 & $-0,03940$ & 0,9687 & & \\
\hline HICP_2 & $-0,234849$ & 0,194351 & $-1,208$ & 0,2299 & & \\
\hline youth_unemp_rate_1 & 0,647802 & 0,0883876 & 7,329 & $7,26 \mathrm{E}-11$ & $* * *$ & \\
\hline youth_unemp_rate_2 & $-0,00991402$ & 0,0863681 & $-0,1148$ & 0,9089 & & \\
\hline Mean dependent var & 24,22815 & & S.D. depende & t var & & 11,15896 \\
\hline Sum squared resid & 265,4529 & & S.E. of regres & ion & & 1,662869 \\
\hline LSDV R-squared & 0,987235 & & Within R-squ & ared & & 0,904262 \\
\hline LSDV F(71, 96) & 104,5706 & & P-value(F) & & & $1,59 \mathrm{E}-68$ \\
\hline Log-likelihood & $-276,8095$ & & Akaike criteri & & & 697,6189 \\
\hline Schwarz criterion & 922,5443 & & Hannan-Quin & & & 788,9046 \\
\hline rho & $-0,297904$ & & Durbin-Watsc & & & 2,214841 \\
\hline \multicolumn{3}{|c|}{$\begin{array}{l}\text { Test statistic: } \mathrm{F}(44,96)=20,6078 \\
\text { with p-value }=\mathrm{P}(\mathrm{F}(44,96)>20,6078)=4,21978 \mathrm{e}-033\end{array}$} & & & & \\
\hline \multicolumn{7}{|c|}{$\begin{array}{l}\text { Test for differing group intercepts - } \\
\text { Null hypothesis: The groups have a common intercept } \\
\text { Test statistic: } F(27,96)=2,73492\end{array}$} \\
\hline
\end{tabular}


with p-value $=\mathrm{P}(\mathrm{F}(27,96)>2,73492)=0,000172124$

Megjegyzés: * jelöli a 10 százalékos, ** az 5 százalékos, *** pedig az 1 százalékos szinten szignifikáns hatással bíró változókat.

Forrás: saját szerkesztés.

5. Az ifjúsági munkanélküliségi arányt befolyásoló tényezők

\begin{tabular}{|c|c|c|c|c|c|}
\hline $\begin{array}{l}\text { FE, } 168 \text { megfigyelés (2 } \\
\text { Függő változó: ifjúság }\end{array}$ & $\begin{array}{l}\text { zág, idősor hossz } \\
\text { nkanélküliségi a }\end{array}$ & $\begin{array}{l}\text { a: } 6 \text { év) } \\
\text { rány }\end{array}$ & & & \\
\hline & együttható & standard hiba & t-arány & p-érték & \\
\hline const & 14,6346 & 20,1726 & 0,7255 & 0,4699 & \\
\hline min_wage & 5,42654 & 6,17017 & 0,8795 & 0,3813 & \\
\hline min_wage_1 & 6,31839 & 5,6169 & 1,125 & 0,2634 & \\
\hline min_wage_2 & 4,90496 & 4,71832 & 1,04 & 0,3012 & \\
\hline tax_wedge & $-0,0536796$ & 0,0599857 & $-0,8949$ & 0,3731 & \\
\hline tax_wedge_1 & 0,0967196 & 0,0710648 & 1,361 & 0,1767 & \\
\hline tax_wedge_2 & 0,160421 & 0,0675524 & 2,375 & 0,0195 & $* *$ \\
\hline trade_union_dens & 0,0144095 & 0,0137113 & 1,051 & 0,2959 & \\
\hline trade_union_dens_1 & $-0,00879868$ & 0,017406 & $-0,5055$ & 0,6144 & \\
\hline trade_union_dens_2 & $-0,00387831$ & 0,0290243 & $-0,1336$ & 0,894 & \\
\hline part_timers & 0,281263 & 0,183925 & 1,529 & 0,1295 & \\
\hline part_timers_1 & $-0,253701$ & 0,190094 & $-1,335$ & 0,1852 & \\
\hline part_timers_2 & $-0,199288$ & 0,14923 & $-1,335$ & 0,1849 & \\
\hline invol_part_timers & 0,0747694 & 0,027542 & 2,715 & 0,0079 & $* * *$ \\
\hline \begin{tabular}{|l|} 
invol_part_timers_1 \\
\end{tabular} & $-0,0102548$ & 0,0275617 & $-0,3721$ & 0,7107 & \\
\hline invol_part_timers_2 & $-0,0304203$ & 0,0251004 & $-1,212$ & 0,2285 & \\
\hline hours_worked & 0,421277 & 0,576099 & 0,7313 & 0,4664 & \\
\hline hours_worked_1 & $-1,47696$ & 0,645564 & $-2,288$ & 0,0243 & $* *$ \\
\hline hours_worked_2 & 0,518707 & 0,453529 & 1,144 & 0,2556 & \\
\hline temporary_emp & 0,138525 & 0,101489 & 1,365 & 0,1755 & \\
\hline temporary_emp_1 & $-0,216988$ & 0,128531 & $-1,688$ & 0,0946 & $*$ \\
\hline temporary_emp_2 & 0,17877 & 0,100835 & 1,773 & 0,0794 & $*$ \\
\hline EPL_regular & $-0,998338$ & 0,464158 & $-2,151$ & 0,034 & $* *$ \\
\hline EPL_regular_1 & 0,113391 & 0,514001 & 0,2206 & 0,8259 & \\
\hline EPL_regular_2 & 1,01627 & 0,603382 & 1,684 & 0,0954 & $*$ \\
\hline EPL_temporary & 0,155126 & 0,243699 & 0,6365 & 0,5259 & \\
\hline EPL_temporary_1 & $-0,0323112$ & 0,295566 & $-0,1093$ & 0,9132 & \\
\hline EPL_temporary_2 & 0,0826335 & 0,369536 & 0,2236 & 0,8235 & \\
\hline ALMP_expend & 0,134597 & 0,989536 & 0,136 & 0,8921 & \\
\hline ALMP_expend_1 & $-0,727112$ & 1,01192 & $-0,7185$ & 0,4742 & \\
\hline ALMP_expend_2 & 1,3879 & 0,895156 & 1,55 & 0,1243 & \\
\hline PLMP_expend & 1,21549 & 0,474987 & 2,559 & 0,0121 & $* *$ \\
\hline PLMP_expend_1 & 0,133864 & 0,558388 & 0,2397 & 0,811 & \\
\hline PLMP_expend_2 & 0,0482951 & 0,50154 & 0,09629 & 0,9235 & \\
\hline GDP_per_cap & 0,0002073 & 0,0001001 & 2,07 & 0,0411 & $* *$ \\
\hline GDP_per_cap_1 & 9,99E-06 & 0,0001012 & 0,09876 & 0,9215 & \\
\hline GDP_per_cap_2 & $-8,38852 \mathrm{e}-05$ & $7,19 \mathrm{E}-05$ & $-1,167$ & 0,2461 & \\
\hline GDP_growth & $-0,166598$ & 0,0484527 & $-3,438$ & 0,0009 & $* * *$ \\
\hline GDP_growth_1 & 0,0915187 & 0,0614749 & 1,489 & 0,1398 & \\
\hline GDP_growth_2 & 0,0017948 & 0,0368511 & 0,0487 & 0,9613 & \\
\hline HICP & 0,096622 & 0,102854 & 0,9394 & 0,3499 & \\
\hline HICP_1 & $-0,0248117$ & 0,119223 & $-0,2081$ & 0,8356 & \\
\hline HICP_2 & $-0,0987252$ & 0,0700664 & $-1,409$ & 0,1621 & \\
\hline youth_unemp_ratio_1 & 0,605017 & 0,10603 & 5,706 & $1,28 \mathrm{E}-07$ & $* * *$ \\
\hline youth_unemp_ratio_2 & $-0,106326$ & 0,0932528 & $-1,140$ & 0,257 & \\
\hline
\end{tabular}




\begin{tabular}{|lrlr|}
\hline Mean dependent var & 9,059524 & S.D. dependent var & 3,449468 \\
Sum squared resid & 35,82184 & S.E. of regression & 0,610855 \\
LSDV R-squared & 0,981973 & Within R-squared & 0,880208 \\
LSDV F(71, 96) & 73,65212 & P-value(F) & $2,08 E-61$ \\
Log-likelihood & $-108,5675$ & Akaike criterion & 361,1351 \\
Schwarz criterion & 586,0605 & Hannan-Quinn & 452,4208 \\
rho & $-0,258378$ & Durbin-Watson & 2,148101 \\
\hline
\end{tabular}

Joint test on named regressors -

Test statistic: $\mathrm{F}(44,96)=16,0316$

with $\mathrm{p}$-value $=\mathrm{P}(\mathrm{F}(44,96)>16,0316)=1,14259 \mathrm{e}-028$

Test for differing group intercepts -

Null hypothesis: The groups have a common intercept

Test statistic: $\mathrm{F}(27,96)=2,81889$

with $\mathrm{p}$-value $=\mathrm{P}(\mathrm{F}(27,96)>2,81889)=0,000111158$

Megjegyzés: * jelöli a 10 százalékos, ** az 5 százalékos, *** pedig az 1 százalékos szinten szignifikáns hatással bíró változókat.

Forrás: saját szerkesztés.

6. A NEET rátát befolyásoló tényezők

FE, 168 megfigyelés (28 ország, idősor hossza: 6 év)

Függő változó: NEET ráta

\begin{tabular}{|c|c|c|c|c|c|}
\hline & együttható & standard hiba & t-arány & p-érték & \\
\hline const & 24,7128 & 21,7147 & 1,138 & 0,2579 & \\
\hline min_wage & 9,24233 & 6,31813 & 1,463 & 0,1468 & \\
\hline min_wage_1 & $-3,05534$ & 5,92382 & $-0,5158$ & 0,6072 & \\
\hline min_wage_2 & 13,4319 & 4,91701 & 2,732 & 0,0075 & $* * *$ \\
\hline tax_wedge & $-0,0188226$ & 0,0630585 & $-0,2985$ & 0,766 & \\
\hline tax_wedge_1 & 0,0427853 & 0,073195 & 0,5845 & 0,5602 & \\
\hline tax_wedge_2 & 0,0020508 & 0,0705068 & 0,02909 & 0,9769 & \\
\hline trade_union_dens & $-0,00902925$ & 0,0140972 & $-0,6405$ & 0,5234 & \\
\hline trade_union_dens_1 & $-0,0154317$ & 0,0176799 & $-0,8728$ & 0,3849 & \\
\hline trade_union_dens_2 & 0,0557959 & 0,029826 & 1,871 & 0,0644 & $*$ \\
\hline part_timers & 0,244227 & 0,192148 & 1,271 & 0,2068 & \\
\hline part_timers_1 & $-0,216868$ & 0,197909 & $-1,096$ & 0,2759 & \\
\hline part_timers_2 & $-0,318935$ & 0,154547 & $-2,064$ & 0,0417 & $* *$ \\
\hline invol_part_timers & 0,0255182 & 0,0291303 & 0,876 & 0,3832 & \\
\hline invol_part_timers_1 & $-0,0204519$ & 0,0282222 & $-0,7247$ & 0,4704 & \\
\hline invol_part_timers_2 & $-0,00523009$ & 0,025055 & $-0,2087$ & 0,8351 & \\
\hline hours_worked & 0,61192 & 0,606229 & 1,009 & 0,3153 & \\
\hline hours_worked_1 & $-2,06209$ & 0,679436 & $-3,035$ & 0,0031 & $* * *$ \\
\hline hours_worked_2 & 0,762216 & 0,473005 & 1,611 & 0,1104 & \\
\hline temporary_emp & 0,119776 & 0,102579 & 1,168 & 0,2458 & \\
\hline temporary_emp_1 & $-0,177282$ & 0,133394 & $-1,329$ & 0,187 & \\
\hline temporary_emp_2 & 0,0662735 & 0,104722 & 0,6329 & 0,5283 & \\
\hline EPL_regular & $-0,571136$ & 0,487952 & $-1,170$ & 0,2447 & \\
\hline EPL_regular_1 & 0,156717 & 0,529351 & 0,2961 & 0,7678 & \\
\hline EPL_regular_2 & $-0,230430$ & 0,603358 & $-0,3819$ & 0,7034 & \\
\hline EPL_temporary & $-0,173320$ & 0,251967 & $-0,6879$ & 0,4932 & \\
\hline EPL_temporary_1 & 0,495361 & 0,309185 & 1,602 & 0,1124 & \\
\hline EPL_temporary_2 & 0,6207 & 0,381966 & 1,625 & 0,1074 & \\
\hline ALMP_expend & 0,954969 & 1,02997 & 0,9272 & 0,3562 & \\
\hline ALMP_expend_1 & $-0,171806$ & 1,06087 & $-0,1619$ & 0,8717 & \\
\hline ALMP_expend_2 & 1,5678 & 0,931909 & 1,682 & 0,0957 & $*$ \\
\hline PLMP_expend & 1,24211 & 0,500485 & 2,482 & 0,0148 & $* *$ \\
\hline
\end{tabular}




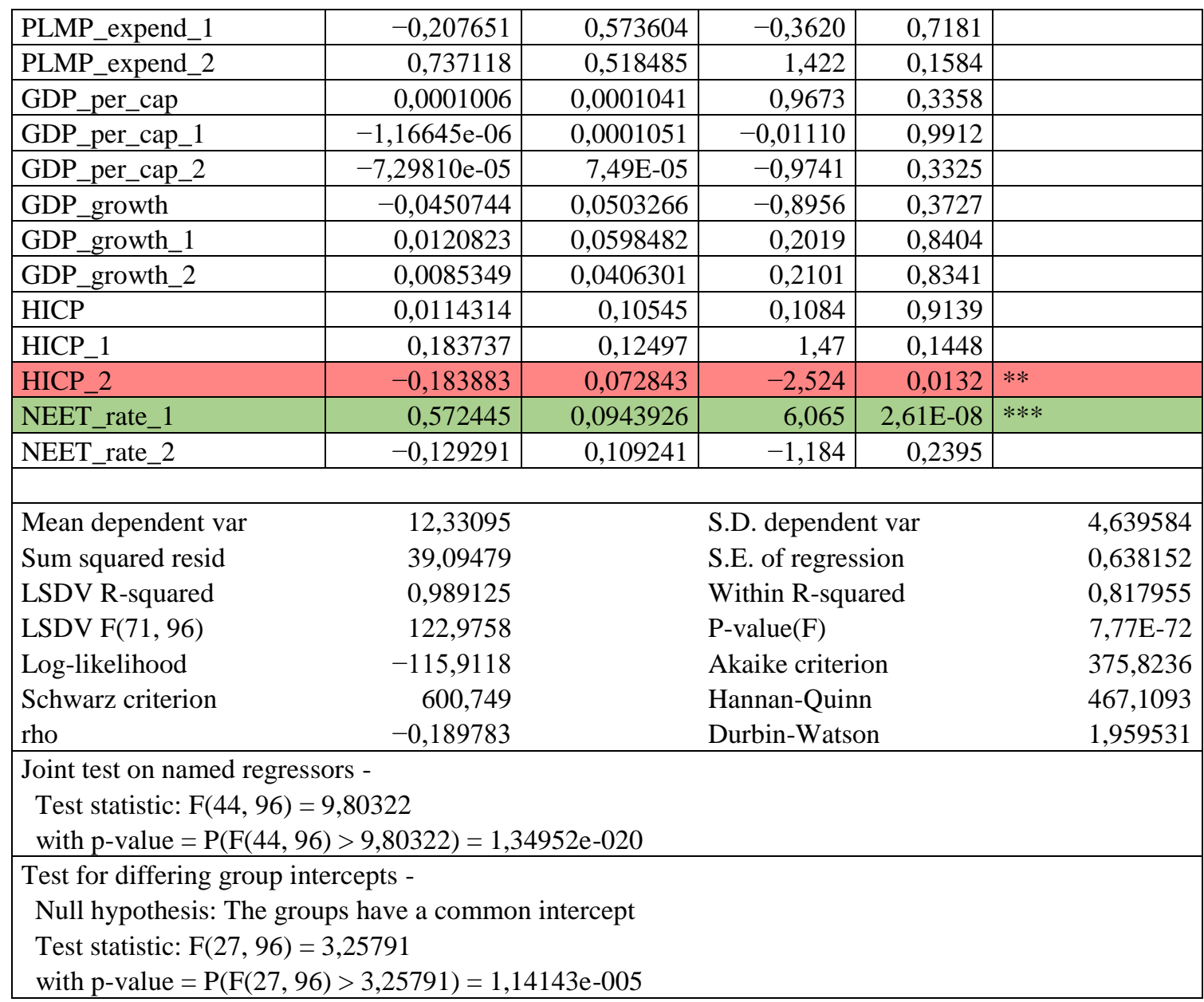

Megjegyzés: * jelöli a 10 százalékos, ** az 5 százalékos, *** pedig az 1 százalékos szinten szignifikáns hatással bíró változókat.

Forrás: saját szerkesztés.

7. A 25-54 éves korosztály foglalkoztatási rátáját befolyásoló tényezők FE, 168 megfigyelés (28 ország, idősor hossza: 6 év)

Függő változó: felnőttek foglalkoztatási rátája

\begin{tabular}{|l|r|r|r|r|l|}
\hline & együttható & standard hiba & t-arány & p-érték & \\
\hline const & 4,09712 & 18,3869 & 0,2228 & 0,8241 & \\
\hline min_wage & 14,8251 & 5,50808 & 2,692 & 0,0084 & $* * *$ \\
\hline min_wage_1 & $-3,33857$ & 5,09747 & $-0,6549$ & 0,5141 & \\
\hline min_wage_2 & $-6,88089$ & 4,28005 & $-1,608$ & 0,1112 & \\
\hline tax_wedge & 0,197256 & 0,0544069 & 3,626 & 0,0005 & $* * *$ \\
\hline tax_wedge_1 & $-0,0393259$ & 0,0645998 & $-0,6088$ & 0,5441 & \\
\hline tax_wedge_2 & $-0,0756439$ & 0,0607702 & $-1,245$ & 0,2163 & \\
\hline trade_union_dens & 0,0465425 & 0,0122004 & 3,815 & 0,0002 & $* * *$ \\
\hline trade_union_dens_1 & $-0,0394337$ & 0,0162579 & $-2,426$ & 0,0172 & $* *$ \\
\hline trade_union_dens_2 & $-0,0543962$ & 0,0266738 & $-2,039$ & 0,0442 & $* *$ \\
\hline part_timers & 0,0143305 & 0,167736 & 0,08543 & 0,9321 & \\
\hline part_timers_1 & 0,168684 & 0,17205 & 0,9804 & 0,3293 & \\
\hline part_timers_2 & 0,242622 & 0,132335 & 1,833 & 0,0698 & $*$ \\
\hline invol_part_timers & $-0,0153587$ & 0,0252321 & $-0,6087$ & 0,5442 & \\
\hline invol_part_timers_1 & $-0,00921168$ & 0,0247536 & $-0,3721$ & 0,7106 & \\
\hline invol_part_timers_2 & $-0,00209119$ & 0,0224743 & $-0,09305$ & 0,9261 & \\
\hline hours_worked & 0,679937 & 0,519111 & 1,31 & 0,1934 & \\
\hline hours_worked_1 & 1,02372 & 0,610687 & 1,676 & 0,0969 & $*$ \\
\hline
\end{tabular}




\begin{tabular}{|c|c|c|c|c|c|c|}
\hline hours_worked_2 & $-1,02777$ & 0,442791 & $-2,321$ & 0,0224 & $* *$ & \\
\hline temporary_emp & 0,214951 & 0,083055 & 2,588 & 0,0111 & *** & \\
\hline temporary_emp_1 & $-0,0316165$ & 0,118618 & $-0,2665$ & 0,7904 & & \\
\hline temporary_emp_2 & $-0,0599520$ & 0,0956077 & $-0,6271$ & 0,5321 & & \\
\hline EPL_regular & 1,00774 & 0,425051 & 2,371 & 0,0197 & $* *$ & \\
\hline EPL_regular_1 & 0,0094012 & 0,464091 & 0,02026 & 0,9839 & & \\
\hline EPL_regular_2 & $-0,0506347$ & 0,608348 & $-0,08323$ & 0,9338 & & \\
\hline EPL_temporary & $-0,0617788$ & 0,222122 & $-0,2781$ & 0,7815 & & \\
\hline EPL_temporary_1 & $-0,156668$ & 0,274642 & $-0,5704$ & 0,5697 & & \\
\hline EPL_temporary_2 & $-0,0284839$ & 0,351969 & $-0,08093$ & 0,9357 & & \\
\hline ALMP_expend & $-0,919169$ & 0,891787 & $-1,031$ & 0,3053 & & \\
\hline ALMP_expend_1 & 0,206764 & 0,919052 & 0,225 & 0,8225 & & \\
\hline ALMP_expend_2 & $-1,06296$ & 0,824879 & $-1,289$ & 0,2006 & & \\
\hline PLMP_expend & $-0,946601$ & 0,430596 & $-2,198$ & 0,0303 & ** & \\
\hline PLMP_expend_1 & $-1,40373$ & 0,490505 & $-2,862$ & 0,0052 & $* * *$ & \\
\hline PLMP_expend_2 & $-0,262760$ & 0,445208 & $-0,5902$ & 0,5564 & & \\
\hline GDP_per_cap & $-0,000264446$ & $8,92 \mathrm{E}-05$ & $-2,964$ & 0,0038 & $* * *$ & \\
\hline GDP_per_cap_1 & $9,71 \mathrm{E}-05$ & 9,09E-05 & 1,069 & 0,2878 & & \\
\hline GDP_per_cap_2 & $5,09 \mathrm{E}-05$ & $6,50 \mathrm{E}-05$ & 0,7829 & 0,4356 & & \\
\hline GDP_growth & 0,128799 & 0,0439321 & 2,932 & 0,0042 & $* * *$ & \\
\hline GDP_growth_1 & 0,0100209 & 0,0533253 & 0,1879 & 0,8513 & & \\
\hline GDP_growth_2 & $-0,0493398$ & 0,0333625 & $-1,479$ & 0,1424 & & \\
\hline HICP & 0,0189997 & 0,0924593 & 0,2055 & 0,8376 & & \\
\hline HICP_1 & $-0,298158$ & 0,108269 & $-2,754$ & 0,007 & $* * *$ & \\
\hline HICP_2 & 0,250558 & 0,0637403 & 3,931 & 0,0002 & $* * *$ & \\
\hline adult_emp_rate_1 & 0,479932 & 0,0747615 & 6,42 & 5,19E-09 & $* * *$ & \\
\hline adult_emp_rate_2 & $-0,00946842$ & 0,0761931 & $-0,1243$ & 0,9014 & & \\
\hline Mean dependent var & 77,77708 & & S.D. depend & ent var & & 5,388814 \\
\hline Sum squared resid & 29,57992 & & S.E. of regre & ssion & & 0,555089 \\
\hline LSDV R-squared & 0,993901 & & Within R-sq & uared & & 0,938737 \\
\hline $\operatorname{LSDV} F(71,96)$ & 220,3239 & & P-value(F) & & & $8,05 \mathrm{E}-84$ \\
\hline Log-likelihood & $-92,48476$ & & Akaike crite & ion & & 328,9695 \\
\hline Schwarz criterion & 553,8949 & & Hannan-Qui & & & 420,2552 \\
\hline rho & $-0,254474$ & & Durbin-Wat & & & 2,030662 \\
\hline \multicolumn{7}{|c|}{$\begin{array}{l}\text { Joint test on named regressors - } \\
\text { Test statistic: } F(44,96)=33,4321 \\
\text { with p-value }=P(F(44,96)>33,4321)=4,49099 \mathrm{e}-042\end{array}$} \\
\hline \multicolumn{7}{|c|}{$\begin{array}{l}\text { Test for differing group intercepts - } \\
\text { Null hypothesis: The groups have a common intercept } \\
\text { Test statistic: } F(27,96)=4,95082 \\
\text { with p-value }=P(F(27,96)>4,95082)=2,80707 \mathrm{e}-009\end{array}$} \\
\hline
\end{tabular}

Megjegyzés: * jelöli a 10 százalékos, ** az 5 százalékos, *** pedig az 1 százalékos szinten szignifikáns hatással bíró változókat.

Forrás: saját szerkesztés.

8. A 25-54 éves korosztály munkanélküliségi rátáját befolyásoló tényezők FE, 168 megfigyelés (28 ország, idősor hossza: 6 év) Függő változó: felnőttek munkanélküliségi rátája

\begin{tabular}{|l|r|r|r|r|l|}
\hline & együttható & standard hiba & t-arány & p-érték & \\
\hline const & 29,7081 & 17,5292 & 1,695 & 0,0934 & $*$ \\
\hline min_wage & $-4,58290$ & 5,24275 & $-0,8741$ & 0,3842 & \\
\hline min_wage_1 & 8,08016 & 4,82376 & 1,675 & 0,0972 & $*$ \\
\hline min_wage_2 & 5,97772 & 4,06266 & 1,471 & 0,1445 & \\
\hline
\end{tabular}




\begin{tabular}{|c|c|c|c|c|c|c|}
\hline tax_wedge & $-0,124621$ & 0,0515383 & $-2,418$ & 0,0175 & $* *$ & \\
\hline tax_wedge_1 & 0,0665631 & 0,0612011 & 1,088 & 0,2795 & & \\
\hline tax_wedge_2 & 0,125179 & 0,0580728 & 2,156 & 0,0336 & $* *$ & \\
\hline trade_union_dens & $-0,0322598$ & 0,0118764 & $-2,716$ & 0,0078 & $* * *$ & \\
\hline trade_union_dens_1 & 0,0361958 & 0,0149168 & 2,427 & 0,0171 & $* *$ & \\
\hline trade_union_dens_2 & 0,0344403 & 0,0255249 & 1,349 & 0,1804 & & \\
\hline part_timers & $-0,0113401$ & 0,160293 & $-0,07075$ & 0,9437 & & \\
\hline part_timers_1 & $-0,163640$ & 0,164689 & $-0,9936$ & 0,3229 & & \\
\hline part_timers_2 & $-0,187929$ & 0,129025 & $-1,457$ & 0,1485 & & \\
\hline invol_part_timers & 0,0019712 & 0,0242321 & 0,08135 & 0,9353 & & \\
\hline invol_part_timers_1 & 0,0348094 & 0,0236481 & 1,472 & 0,1443 & & \\
\hline invol_part_timers_2 & $-0,0266761$ & 0,0211974 & $-1,258$ & 0,2113 & & \\
\hline hours_worked & $-0,999248$ & 0,503016 & $-1,987$ & 0,0498 & $* *$ & \\
\hline hours_worked_1 & $-0,899174$ & 0,580248 & $-1,550$ & 0,1245 & & \\
\hline hours_worked_2 & 1,04587 & 0,406879 & 2,57 & 0,0117 & $* *$ & \\
\hline temporary_emp & $-0,208508$ & 0,0843399 & $-2,472$ & 0,0152 & $* *$ & \\
\hline temporary_emp_1 & 0,036204 & 0,112188 & 0,3227 & 0,7476 & & \\
\hline temporary_emp_2 & 0,160704 & 0,091398 & 1,758 & 0,0819 & $*$ & \\
\hline EPL_regular & $-0,717885$ & 0,40268 & $-1,783$ & 0,0778 & $*$ & \\
\hline EPL_regular_1 & $-0,424942$ & 0,438829 & $-0,9684$ & 0,3353 & & \\
\hline EPL_regular_2 & 1,49484 & 0,518209 & 2,885 & 0,0048 & $* * *$ & \\
\hline EPL_temporary & $-0,0387160$ & 0,210586 & $-0,1838$ & 0,8545 & & \\
\hline EPL_temporary_1 & 0,0116778 & 0,260282 & 0,04487 & 0,9643 & & \\
\hline EPL_temporary_2 & $-0,0850370$ & 0,325359 & $-0,2614$ & 0,7944 & & \\
\hline ALMP_expend & 0,629751 & 0,849044 & 0,7417 & 0,4601 & & \\
\hline ALMP_expend_1 & 0,15349 & 0,874194 & 0,1756 & 0,861 & & \\
\hline ALMP_expend_2 & 1,02106 & 0,774535 & 1,318 & 0,1905 & & \\
\hline PLMP_expend & 1,07867 & 0,41509 & 2,599 & 0,0108 & $* *$ & \\
\hline PLMP_expend_1 & 0,767242 & 0,495122 & 1,55 & 0,1245 & & \\
\hline PLMP_expend_2 & $-0,506413$ & 0,420635 & $-1,204$ & 0,2316 & & \\
\hline GDP_per_cap & 0,000264 & $8,55 \mathrm{E}-05$ & 3,088 & 0,0026 & $* * *$ & \\
\hline GDP_per_cap_1 & $-9,10982 \mathrm{e}-05$ & $8,75 \mathrm{E}-05$ & $-1,041$ & 0,3003 & & \\
\hline GDP_per_cap_2 & $-6,04398 \mathrm{e}-05$ & $6,23 \mathrm{E}-05$ & $-0,9699$ & 0,3345 & & \\
\hline GDP_growth & $-0,150744$ & 0,0417813 & $-3,608$ & 0,0005 & $* * *$ & \\
\hline GDP_growth_1 & 0,0539316 & 0,0532085 & 1,014 & 0,3133 & & \\
\hline GDP_growth_2 & 0,0655135 & 0,0324587 & 2,018 & 0,0463 & $* *$ & \\
\hline HICP & 0,0077096 & 0,0873008 & 0,08831 & 0,9298 & & \\
\hline HICP_1 & 0,210718 & 0,10355 & 2,035 & 0,0446 & $* *$ & \\
\hline HICP_2 & $-0,225011$ & 0,0602577 & $-3,734$ & 0,0003 & $* * *$ & \\
\hline adult_unemp_rate_1 & 0,790072 & 0,0730774 & 10,81 & $2,72 \mathrm{E}-18$ & $* * *$ & \\
\hline adult_unemp_rate_2 & $-0,0259987$ & 0,0691489 & $-0,3760$ & 0,7078 & & \\
\hline Mean dependent var & 9,330677 & & S.D. depend & ent var & & 4,777575 \\
\hline Sum squared resid & 26,95435 & & S.E. of regre & ssion & & 0,529882 \\
\hline LSDV R-squared & 0,992929 & & Within R-sq & dared & & 0,95161 \\
\hline LSDV F(71, 96) & 189,86 & & P-value(F) & & & $9,40 \mathrm{E}-81$ \\
\hline Log-likelihood & $-84,67687$ & & Akaike crite & ion & & 313,3537 \\
\hline Schwarz criterion & 538,2791 & & Hannan-Qui & & & 404,6394 \\
\hline rho & $-0,191013$ & & Durbin-Wat & ion & & 1,974502 \\
\hline \multicolumn{2}{|c|}{$\begin{array}{l}\text { Test statistic: } F(44,96)=42,9066 \\
\text { with p-value }=P(F(44,96)>42,9066)=7,18472 \mathrm{e}-047\end{array}$} & $2 \mathrm{e}-047$ & & & & \\
\hline $\begin{array}{l}\text { Test for differing grou } \\
\text { Null hypothesis: The } \\
\text { Test statistic: } F(27,\end{array}$ & $\begin{array}{l}\text { cepts - } \\
\text { s have a commor } \\
24486\end{array}$ & ercept & & & & \\
\hline
\end{tabular}


with p-value $=\mathrm{P}(\mathrm{F}(27,96)>4,24486)=8,037 \mathrm{e}-008$

Megjegyzés: * jelöli a 10 százalékos, ** az 5 százalékos, *** pedig az 1 százalékos szinten szignifikáns hatással bíró változókat.

Forrás: saját szerkesztés.

9. Az 55-64 éves korosztály foglalkoztatási rátáját befolyásoló tényezők

FE, 168 megfigyelés (28 ország, idősor hossza: 6 év)

Függő változó: idősebbek foglalkoztatási rátája

\begin{tabular}{|c|c|c|c|c|c|}
\hline & együttható & standard hiba & t-arány & p-érték & \\
\hline const & 45,0882 & 38,2975 & 1,177 & 0,242 & \\
\hline min_wage & $-3,74686$ & 11,035 & $-0,3395$ & 0,7349 & \\
\hline min_wage_1 & $-11,5326$ & 10,3878 & $-1,110$ & 0,2697 & \\
\hline min_wage_2 & 13,7189 & 8,68469 & 1,58 & 0,1175 & \\
\hline tax_wedge & $-0,0498945$ & 0,10973 & $-0,4547$ & 0,6504 & \\
\hline tax_wedge_1 & $-0,0715190$ & 0,131311 & $-0,5447$ & 0,5873 & \\
\hline tax_wedge_2 & 0,0378178 & 0,125329 & 0,3017 & 0,7635 & \\
\hline trade_union_dens & 0,0684973 & 0,0247952 & 2,763 & 0,0069 & $* * *$ \\
\hline trade_union_dens_1 & $-0,0655694$ & 0,0311466 & $-2,105$ & 0,0379 & $* *$ \\
\hline trade_union_dens_2 & 0,0054748 & 0,0535465 & 0,1022 & 0,9188 & \\
\hline part_timers & 0,0488191 & 0,338831 & 0,1441 & 0,8857 & \\
\hline part_timers_1 & $-0,232408$ & 0,352621 & $-0,6591$ & 0,5114 & \\
\hline part_timers_2 & 0,24607 & 0,266438 & 0,9236 & 0,358 & \\
\hline invol_part_timers & $-0,0509164$ & 0,0526284 & $-0,9675$ & 0,3357 & \\
\hline invol_part_timers_1 & $-0,0720087$ & 0,0500822 & $-1,438$ & 0,1537 & \\
\hline invol_part_timers_2 & 0,0150269 & 0,0442036 & 0,3399 & 0,7346 & \\
\hline hours_worked & $-0,0927971$ & 1,06023 & $-0,08753$ & 0,9304 & \\
\hline hours_worked_1 & 0,777344 & 1,25789 & 0,618 & 0,5381 & \\
\hline hours_worked_2 & $-1,84052$ & 0,863015 & $-2,133$ & 0,0355 & $* *$ \\
\hline temporary_emp & $-0,0486628$ & 0,170666 & $-0,2851$ & 0,7762 & \\
\hline temporary_emp_1 & $-0,0881575$ & 0,229584 & $-0,3840$ & 0,7018 & \\
\hline temporary_emp_2 & 0,189935 & 0,184103 & 1,032 & 0,3048 & \\
\hline EPL_regular & $-0,384679$ & 0,859388 & $-0,4476$ & 0,6554 & \\
\hline EPL_regular_1 & $-0,496101$ & 0,925998 & $-0,5357$ & 0,5934 & \\
\hline EPL_regular_2 & $-1,65421$ & 1,05487 & $-1,568$ & 0,1201 & \\
\hline EPL_temporary & 0,772436 & 0,444161 & 1,739 & 0,0852 & $*$ \\
\hline EPL_temporary_1 & $-0,112650$ & 0,548001 & $-0,2056$ & 0,8376 & \\
\hline EPL_temporary_2 & $-0,989514$ & 0,675516 & $-1,465$ & 0,1462 & \\
\hline ALMP_expend & 0,837243 & 1,8364 & 0,4559 & 0,6495 & \\
\hline ALMP_expend_1 & 2,0299 & 1,8589 & 1,092 & 0,2776 & \\
\hline ALMP_expend_2 & $-1,94317$ & 1,6428 & $-1,183$ & 0,2398 & \\
\hline PLMP_expend & 0,876312 & 0,877909 & 0,9982 & 0,3207 & \\
\hline PLMP_expend_1 & $-2,35088$ & 0,943981 & $-2,490$ & 0,0145 & $* *$ \\
\hline PLMP_expend_2 & 1,99718 & 0,873381 & 2,287 & 0,0244 & $* *$ \\
\hline GDP_per_cap & $-0,000200123$ & 0,0001801 & $-1,111$ & 0,2692 & \\
\hline GDP_per_cap_1 & $1,01 \mathrm{E}-06$ & 0,0001847 & 0,005487 & 0,9956 & \\
\hline GDP_per_cap_2 & $-8,48794 \mathrm{e}-05$ & 0,0001332 & $-0,6374$ & 0,5254 & \\
\hline GDP_growth & 0,158414 & 0,0888034 & 1,784 & 0,0776 & $*$ \\
\hline GDP_growth_1 & $-0,0939012$ & 0,105007 & $-0,8942$ & 0,3734 & \\
\hline GDP_growth_2 & 0,0662339 & 0,0715912 & 0,9252 & 0,3572 & \\
\hline $\mathrm{HICP}$ & 0,162028 & 0,184646 & 0,8775 & 0,3824 & \\
\hline HICP_1 & $-0,227137$ & 0,219924 & $-1,033$ & 0,3043 & \\
\hline HICP_2 & 0,243985 & 0,132418 & 1,843 & 0,0685 & $*$ \\
\hline old_emp_rate_1 & 0,699511 & 0,101232 & 6,91 & $5,30 \mathrm{E}-10$ & $* * *$ \\
\hline old_emp_rate_2 & 0,0547195 & 0,0978036 & 0,5595 & 0,5771 & \\
\hline
\end{tabular}




\begin{tabular}{|lrlr|}
\hline Mean dependent var & 48,26544 & S.D. dependent var & 10,02664 \\
Sum squared resid & 121,5372 & S.E. of regression & 1,125172 \\
LSDV R-squared & 0,992761 & Within R-squared & 0,901138 \\
LSDV F(71, 96) & 185,428 & P-value(F) & $2,88 E-80$ \\
Log-likelihood & $-211,1872$ & Akaike criterion & 566,3744 \\
Schwarz criterion & 791,2998 & Hannan-Quinn & 657,6601 \\
rho & $-0,250165$ & Durbin-Watson & 1,999812 \\
\hline
\end{tabular}

Joint test on named regressors -

Test statistic: $F(44,96)=19,8875$

with $\mathrm{p}$-value $=\mathrm{P}(\mathrm{F}(44,96)>19,8875)=1,83645 \mathrm{e}-032$

Test for differing group intercepts -

Null hypothesis: The groups have a common intercept

Test statistic: $\mathrm{F}(27,96)=1,70498$

with $\mathrm{p}$-value $=\mathrm{P}(\mathrm{F}(27,96)>1,70498)=0,0312161$

Megjegyzés: * jelöli a 10 százalékos, ** az 5 százalékos, *** pedig az 1 százalékos szinten szignifikáns hatással bíró változókat.

Forrás: saját szerkesztés.

10. Az 55-64 éves korosztály munkanélküliségi rátáját befolyásoló tényezők FE, 168 megfigyelés (28 ország, idősor hossza: 6 év)

Függő változó: idősebbek munkanélküliségi rátája

\begin{tabular}{|c|c|c|c|c|c|}
\hline & együttható & standard hiba & t-arány & p-érték & \\
\hline const & $-22,5480$ & 27,8371 & $-0,8100$ & 0,4199 & \\
\hline min_wage & 3,03392 & 8,31015 & 0,3651 & 0,7159 & \\
\hline min_wage_1 & 8,00557 & 7,71054 & 1,038 & 0,3018 & \\
\hline min_wage_2 & 0,935142 & 6,61616 & 0,1413 & 0,8879 & \\
\hline tax_wedge & $-0,0483033$ & 0,0822591 & $-0,5872$ & 0,5584 & \\
\hline tax_wedge_1 & 0,10623 & 0,0982455 & 1,081 & 0,2823 & \\
\hline tax_wedge_2 & 0,103962 & 0,0924157 & 1,125 & 0,2634 & \\
\hline trade_union_dens & $-0,0237014$ & 0,0185675 & $-1,276$ & 0,2049 & \\
\hline trade_union_dens_1 & $-0,00529173$ & 0,0233259 & $-0,2269$ & 0,821 & \\
\hline trade_union_dens_2 & $-0,0800632$ & 0,0401862 & $-1,992$ & 0,0492 & $* *$ \\
\hline part_timers & 0,291112 & 0,254134 & 1,146 & 0,2548 & \\
\hline part_timers_1 & 0,0030618 & 0,264012 & 0,0116 & 0,9908 & \\
\hline part_timers_2 & 0,113225 & 0,200614 & 0,5644 & 0,5738 & \\
\hline invol_part_timers & 0,0390874 & 0,0386451 & 1,011 & 0,3143 & \\
\hline invol_part_timers_1 & 0,0614318 & 0,0377318 & 1,628 & 0,1068 & \\
\hline invol_part_timers_2 & $-0,0520272$ & 0,0338922 & $-1,535$ & 0,1281 & \\
\hline hours_worked & $-0,219644$ & 0,787935 & $-0,2788$ & 0,781 & \\
\hline hours_worked_1 & $-0,238169$ & 0,901666 & $-0,2641$ & 0,7922 & \\
\hline hours_worked_2 & 0,954172 & 0,629263 & 1,516 & 0,1327 & \\
\hline temporary_emp & 0,134744 & 0,129627 & 1,039 & 0,3012 & \\
\hline temporary_emp_1 & 0,210292 & 0,175165 & 1,201 & 0,2329 & \\
\hline temporary_emp_2 & $-0,140924$ & 0,139874 & $-1,008$ & 0,3162 & \\
\hline EPL_regular & $-0,906773$ & 0,640258 & $-1,416$ & 0,1599 & \\
\hline EPL_regular_1 & 0,204423 & 0,704257 & 0,2903 & 0,7722 & \\
\hline EPL_regular_2 & 2,04756 & 0,816214 & 2,509 & 0,0138 & $* *$ \\
\hline EPL_temporary & $-0,654682$ & 0,332878 & $-1,967$ & 0,0521 & $*$ \\
\hline EPL_temporary_1 & $-0,545160$ & 0,424747 & $-1,283$ & 0,2024 & \\
\hline EPL_temporary_2 & $-1,15330$ & 0,533409 & $-2,162$ & 0,0331 & $* *$ \\
\hline ALMP_expend & $-2,61808$ & 1,3622 & $-1,922$ & 0,0576 & $*$ \\
\hline ALMP_expend_1 & 0,214894 & 1,41068 & 0,1523 & 0,8792 & \\
\hline ALMP_expend_2 & 1,10841 & 1,23249 & 0,8993 & 0,3707 & \\
\hline PLMP_expend & $-0,453591$ & 0,667578 & $-0,6795$ & 0,4985 & \\
\hline
\end{tabular}




\begin{tabular}{|c|c|c|c|c|c|c|}
\hline PLMP_expend_1 & 1,93939 & 0,728239 & 2,663 & 0,0091 & $* * *$ & \\
\hline PLMP_expend_2 & $-0,580627$ & 0,678639 & $-0,8556$ & 0,3944 & & \\
\hline GDP_per_cap & 0,0002256 & 0,0001356 & 1,663 & 0,0995 & $*$ & \\
\hline GDP_per_cap_1 & $2,64 \mathrm{E}-05$ & 0,0001387 & 0,1906 & 0,8492 & & \\
\hline GDP_per_cap_2 & $1,39 \mathrm{E}-05$ & $9,92 \mathrm{E}-05$ & 0,1399 & 0,889 & & \\
\hline GDP_growth & $-0,0989789$ & 0,0669539 & $-1,478$ & 0,1426 & & \\
\hline GDP_growth_1 & $-0,163729$ & 0,0818115 & $-2,001$ & 0,0482 & $* *$ & \\
\hline GDP_growth_2 & 0,0651726 & 0,0506889 & 1,286 & 0,2016 & & \\
\hline $\mathrm{HICP}$ & 0,109079 & 0,138757 & 0,7861 & 0,4337 & & \\
\hline HICP_1 & 0,0517218 & 0,165148 & 0,3132 & 0,7548 & & \\
\hline HICP_2 & $-0,115254$ & 0,0968586 & $-1,190$ & 0,237 & & \\
\hline old_unemp_rate_1 & 0,40497 & 0,0965689 & 4,194 & $6,12 \mathrm{E}-05$ & $* * *$ & \\
\hline old_unemp_rate_2 & $-0,0612499$ & 0,0893423 & $-0,6856$ & 0,4946 & & \\
\hline Mean dependent var & \multicolumn{2}{|l|}{7,772522} & \multicolumn{2}{|c|}{ S.D. dependent var } & & 3,910423 \\
\hline Sum squared resid & \multicolumn{2}{|l|}{68,22717} & \multicolumn{2}{|c|}{ S.E. of regression } & & 0,84303 \\
\hline LSDV R-squared & \multicolumn{2}{|l|}{0,973283} & \multicolumn{2}{|c|}{ Within R-squared } & & 0,879899 \\
\hline LSDV F(71, 96) & \multicolumn{2}{|l|}{49,25592} & \multicolumn{2}{|l|}{ P-value(F) } & & $2,46 \mathrm{E}-53$ \\
\hline Log-likelihood & \multicolumn{2}{|l|}{$-162,6875$} & \multicolumn{2}{|c|}{ Akaike criterion } & & 469,375 \\
\hline Schwarz criterion & \multirow{2}{*}{\multicolumn{2}{|c|}{$\begin{array}{r}694,3004 \\
-0,136994\end{array}$}} & \multicolumn{2}{|c|}{ Hannan-Quinn } & & 560,6607 \\
\hline rho & & & \multicolumn{2}{|c|}{ Durbin-Watson } & & 1,91525 \\
\hline \multicolumn{7}{|c|}{$\begin{array}{l}\text { Joint test on named regressors - } \\
\text { Test statistic: } \mathrm{F}(44,96)=15,9847 \\
\text { with p-value }=\mathrm{P}(\mathrm{F}(44,96)>15,9847)=1,28356 \mathrm{e}-028\end{array}$} \\
\hline \multicolumn{7}{|c|}{$\begin{array}{l}\text { Test for differing group intercepts - } \\
\text { Null hypothesis: The groups have a common intercept } \\
\text { Test statistic: } F(27,96)=2,07664 \\
\text { with p-value }=P(F(27,96)>2,07664)=0,00511298\end{array}$} \\
\hline
\end{tabular}

Megjegyzés: * jelöli a 10 százalékos, ** az 5 százalékos, *** pedig az 1 százalékos szinten szignifikáns hatással bíró változókat.

Forrás: saját szerkesztés. 